Universidade Estadual Paulista

Faculdade de Ciências e Tecnologia

Campus de Presidente Prudente

\title{
SOSP
}

\section{O sistema GTP (Geossistema-Território-Paisagem) aplicado ao estudo sobre as dinâmicas socioambientais em Mirante do Paranapanema-SP. \\ $\operatorname{son}$}

Reginaldo José de Souza

Orientador: Prof. Dr. Messias Modesto dos Passos

Presidente Prudente 2010 
Universidade Estadual Paulista

Faculdade de Ciências e Tecnologia

Campus de Presidente Prudente

Programa de Pós-Graduação em Geografia - Mestrado Área de Concentração: Produção do Espaço Geográfico

Linha de Pesquisa: Dinâmica e Gestão Ambiental

Projeto Temático de Vinculação: Dinâmicas Socioambientais, Desenvolvimento Local e Sustentabilidade na Raia Divisória SP-PR-MS

O sistema GTP (Geossistema-Território-Paisagem) aplicado ao estudo sobre as dinâmicas socioambientais em Mirante do Paranapanema-SP

Dissertação de Mestrado elaborada junto ao Programa de Pós-Graduação em Geografia, área de concentração: Produção do Espaço Geográfico, sob orientação do Prof. Dr. Messias Modesto dos Passos.

Reginaldo José de Souza

Abril de 2010 


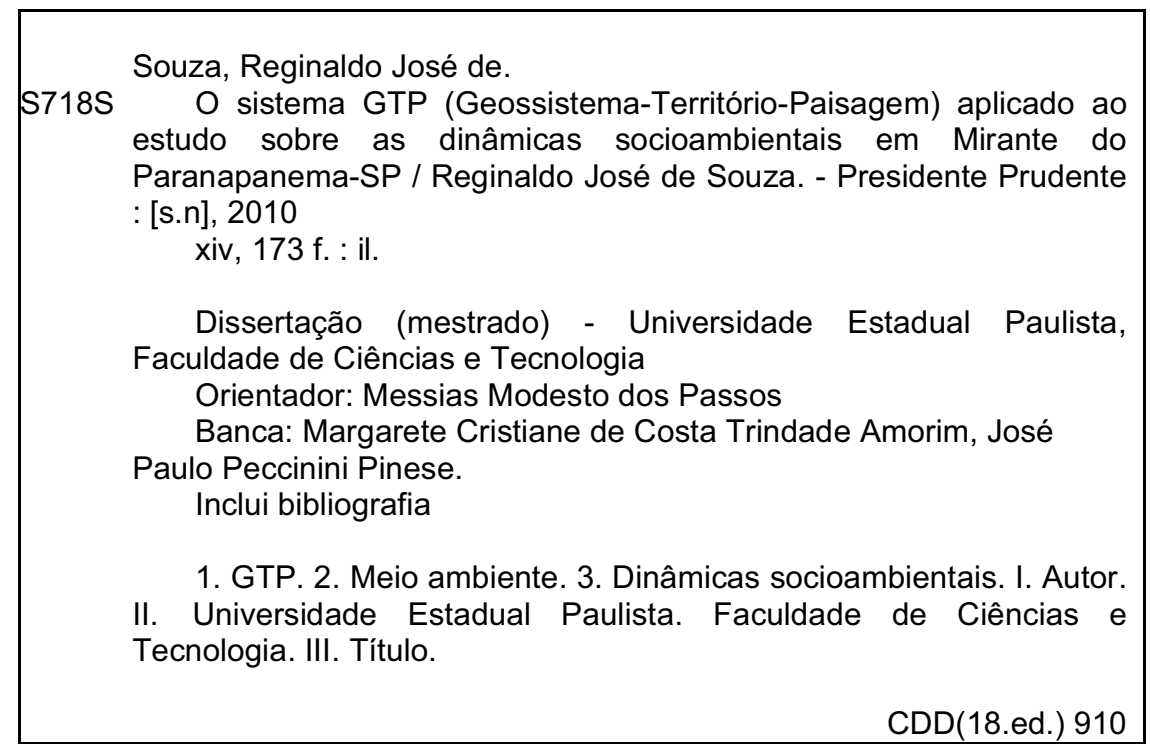

Ficha catalográfica elaborada pela Seção Técnica de Aquisição e Tratamento da Informação Serviço Técnico de Biblioteca e Documentação - UNESP, Câmpus de Presidente Prudente. 


\section{unesp

\section{BANCA EXAMINADORA}

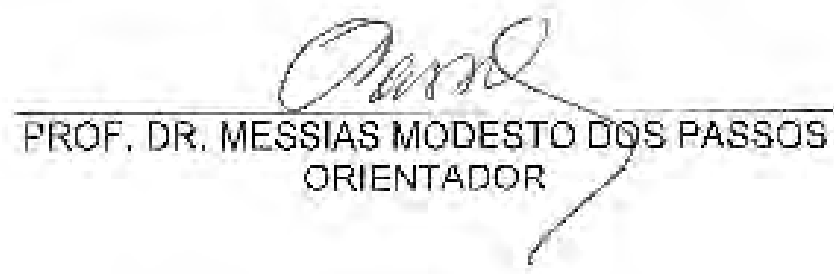

PROFA. DRA. MARGARETE C. C. TRINDADE AMORIM (UNESP/FCT)

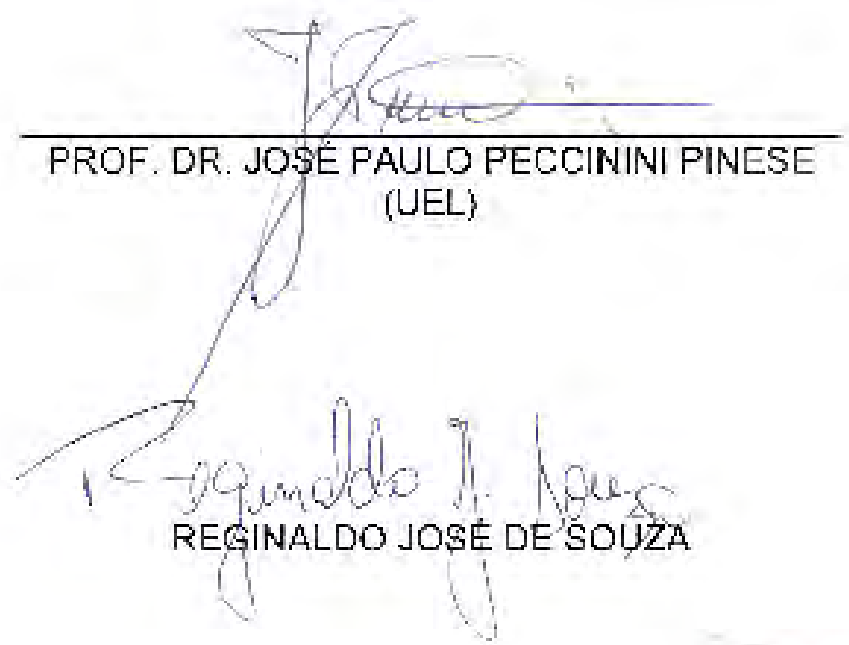

Presidente Prudente (SP). 05 de março de 2010.

RESULTADO:

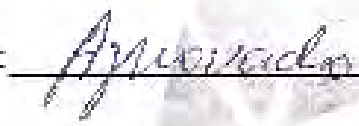

Farultards de Cènaiss :- Trenal:gia

Sespo de Pus-Gradt $3 c$ so

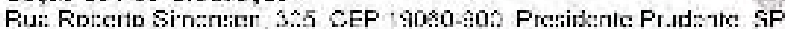

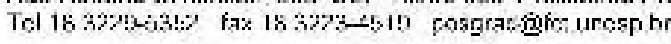


Apoio:

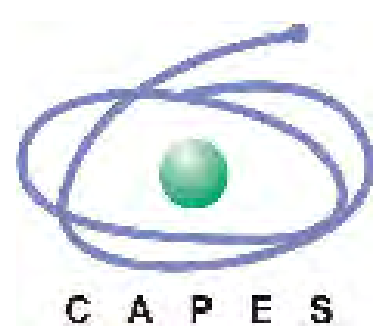

FAPESP 
Dedico este trabalho às eternas referências em minha vida:

Meus pais: Miguel S. Souza e Carmelita S. Souza;

O Professor Messias M. dos Passos;

As grandes amigas Paula V. de Faria Lindo e Valéria Lima. 
$\sin$

A natureza

É uma força

Imprevisível

Um mergulto

$\mathcal{N} a$ vida

$\mathcal{N} a s$ águas

$\mathcal{N}$ os ares

Nas terras

Em todo universo

A natureza é um verso

Abriga

$\mathrm{O}$ raso e efêmero

Abismo

Da nossa cultura

A natureza é mistura

Nexus

Plexus

De toda matéria

Eros de todos os amores

É a morte in natura

Beleza

Equilíbrio

Catástrofe

A natureza é uma arte

De um átomo

A todas as paisagens

Um misterioso texto

Expresso

Em miragens...

(Epígrafe à Natureza / Reginaldo José de Souza)

SOSR 


\section{Agradecimentos}

Estar prestes a ser Mestre no âmbito de uma disciplina científica que, dia após dia, faz com que por ela eu me apaixone cada vez mais e mais é um acontecimento relevante. Sempre me Cembrarei disso.

Sendo assim, eu não poderia deixar passar em branco certas coisas. Não poderia me esquivar de palavras relevantes. De menções a todos aqueles que foram e que são importantes para mim seja durante a minha trajetória nesta instituição de ensino que tanto gosto - um brinde a nossa UNESP e a todas as coisas boas que nos proporciona! - seja na minha vida como um todo.

Primeiramente, agradeço à CAPES e à FAPESP pelas respectivas 6olsas concedidas e que foram de suma importância para o desenvolvimento da pesquisa. E agradeço às seguintes pessoas:

- Ao Professor Messias Modesto dos Passos. Eu o admiro por sua intelectualidade. Por Gasear sua orientação em um princípio de liberdade e respeito pelo que seus orientandos pensam, sistematizam e escrevem. Vma de suas características mais interessantes é a presteza em esclarecer dúvidas sem dar respostas exatamente prontas. Não há nada de mais agradável do que ter um orientador que evita "injetar" idéias estabelecidas em nossas cabeças. O Professor Messias sempre será a minha referência e exemplo de profissional e ser humano a ser seguido;

- Aos Professores João Osvaldo R. Nunes e Margarete C. C. Trindade Amorim. Pelas importantes contribuições ao nosso trabalho na ocasião do Exame Geral de Qualificação. Igualmente duas grandes referências, não apenas pelos competentes e excelentes profissionais que são. Mas também pela simpatia e calor humano que transmitem. Embora colegas de profissão - como sempre salienta o João - jamais conseguirei me desvencilhar completamente do "Professor" ou "Professora" ao me referir a vocês, por todo respeito devido à plena consciência de que sempre terei algo a aprender com ambos; 
- Ao Professor José Paulo P. Pinese (Universidade Estadual de Londrina), por atenciosamente aceitar o nosso convite para compor a banca examinadora na defesa da Dissertação e por suas relevantes críticas e contribuições aos ajustes finais deste trabalho;

- Ao tão atencioso, competente e (o melhor de tudo!) divertido quadro de funcionários da Seção de Pós-Graduação: Ivonete, Eirynati, Márcia, Cínthia e André. Sempre dispostos a esclarecer dúvidas com toda presteza e sempre cheios de paciência às minhas freqüentes $e$ insistentes visitas em busca de documentações! (Acrescentados os dias em que me esquecia de realizar as matrículas anuais!)

- Eu agradeço aos meus pais. Agora e eternamente por qualquer coisa boa que acontece/acontecerá enquanto eu existir neste mundo. Miguel e Carmelita. Agradeço a eles por dois motivos simples e complexos: eu os amo e eles me amam. Por isto! Ambos possuem uma capacidade tão grande de me admirar incondicionalmente que às vezes fico perplexo. Ainda cuidam de mim como se eu fosse o moleque inocente de muitos anos atrás. E eu não sou mais... E eles sabem... E seus cuidados se tornam ainda mais nobres e mais lindos!;

- Às duas mulheres mais Coucas e "atacadas" desta vida! Minhas irmãs. Regina e Regiane. Merecedoras de uma abordagem "a la Almodóvar". Quando nos reunimos para aquele "6reakfast", com direito a todas as 6obagens possiveis, o tempo simplesmente pára!;

- Pela intensidade. Abstracionismo. Surrealismo. Discussões. Brigas! Lealdade. Honestidade. Amizade. "Cala a 6oca Reginaldo!". Yin yang personificado em corpo de mulher. Por toda sua energia ora reprimida ora extravasada. Extravagante. Minha "Mori". Agradeço à Paula Lindo. Por quem eu sinto um carinho imenso. Ela é complexamente fantástica e imprevisível. Sua inteligência me inspira, provoca e movimenta. Certamente uma amiga para toda vida;

- Ao querido. Ao amigo. "Oi, tudo 6em?" "Tudo 6om, e vocêe?" "Tudo 6em, também" "E você??"... Ao Igor Catalão. Um sujeito arredio no começo. Depois um dos amigos mais importantes na sua vida. Na minha. Ele é um intelectual que nasceu pronto. Sua inteligência me emociona e quando me elogia eu quase não acredito. Nãa que suas palavras não tenham validade. Muito pelo contrário! Eu quase não acredito porque ele é tão criterioso, exigente e sóbrio que faz com que a gente desconfie! (“É uma loucuraaaaaaaa!”); 
- À Maria Angélica Oliveira. Por sua delicadeza, carinho, amizade. É uma pessoa importante para mim. Adoro quando nos juntamos para "tirar onda" de certas situações! É impressionante como temos uma sintonia! Certos sinais são captados apenas por nós e mais ninguém! E rimos... E rimos... Ou nos Camentamos... Mas sempre voltamos a rir depois! (Nãa sei se somos primos ou irmãos, sei apenas que nosso avô se chama Kiko e ele vive lá depois do Rio Paraná!);

- Agradeço à querida Érica Pichinin. Uma amiga que guardo no coração sempre. Não temos mais uma convivência quotidiana, porém, seu bom humor, sua alegria de viver, seu carisma são marcas registradas nos nossos reencontros. $\mathcal{N a d a}$ muda a amizade que sinto por você!;

- Aos caríssimos Márcio e Letícia. O casal mais divertido que já conheci. Por nossa amizade descontraída. Por nossos encontros e reencontros espontâneos e tão cheios de piadas, risos e/ou conversas das mais sérias e produtivas. Sempre admirarei aos dois!

- Agradeço aos novíssimos e tão lindos amigos conquistados durante o curso de Mestrado:

Bruna Menezes - Sempre cativante, carinhosa e atenciosa. Vma garota fantástica e cheia de luz.

Camila Grosso de Souza - Maravilhosa. Adoro o seu jeito de "chegar chegando"!

Antonio Henrique Bernardes - Popularmente conhecido como "coléééééga". Este é do tipo que deixa a gente à vontade pra falar o que der na telha logo de cara!

Natacha Aleixo - Esta é membro da trupe! A rainha de todas as 6aterias! Ela é inteligentíssima e divertida a mesmo tempo. Eu não consigo me referir a ela sem inúmeros pontos de exclamação!!! Nat!!! Ela chegou e transformou a minha personalidade: a. $\mathcal{N}$. / d. N. Amo você!

Valéria Lima - Digi! Eu também me apaixonei logo de cara! Adoro a forma como nossa amizade se consolida dia após dia. A relação de respeito que já estabelecemos um com o outro. Os nossos diálogos que vagueiam entre o corriqueiro e o abstrato. Por sua parceria. Pela sua 
presteza em sempre me ajudar quando preciso sem medir esforços. Ela é uma espécie de anjo que apareceu no meu dia-a-dia. Seu apoio, em todos os sentidos, faz com que eu sempre acredite no que há de mais belo e etéreo em uma verdadeira relação de amizade. Amo você Digi!

Mauro e Joãozinho - Não tem como dissociar estas duas figuras! Seres humanos incríveis e cheios de bom humor. Donos da casa mais Gadalada e aconchegante da cidade. Um lugar que jamais se repetirá na história desta pós-graduação!

- Aos queridos amigos que estão Conge de Presidente Prudente, mas que jamais esqueço pela relevância que possuem na minha vida:

Raphael B. Vila Real - confidente, companheiro, compreensivo. Por nossos réveillons abstratos, por diálogos etéreos, pelas filosofias de 6oteco tão necessárias, por sempre compreender o meu comportamento inconstante! Albert Camus, Henry Müller, Milan Kundera e Yukio Mishima sempre me farão pensar em você!

Sandra Engel - amiga de anos-luz atrás. Por levar mais alegrias à vida do meu irmãozinho PH!;

Daniel Matsuzaki - sua inteligência e capacidade de reflexão sempre foram alvo da minha admiração;

Paula Revoredo - dona do olhar mais doce em todo o mundo. Pela leveza, pelas viagens no alpendre com direito a vinhos e reflexões sobre o universo de uma Clarice Lispector, pelas nossas danças que sempre me tiraram da realidade!;

Carolina Israel - amiga das mais dedicadas. Por me introduzir no universo dos romances de Jean Paul Sartre, nas cores de Almodóvar, nos povoados pacatos e solitários de Gabriel García Márquez, nos tangos estilizados de um Gotan Project. Por nossas catarses após "The Dreamers" de Bernardo Bertolucci. Por nossas tardes de café com sorvete, so6 influência de Juliette Binoche em "A Liberdade é Azul"... N Nunca vou me esquecer! Por arrebentar meus "paradigmas morais" com a "Philosophie dans le Boudoir" du monsieur Donatien Alphonse François de Sade! Sinto sempre sua falta!;

Mariana Porto - a minha ariana preferida. Você é parte da minha família... 
Melina Sanches - uma princesa. Nenhuma palavra a mais nem a menos...

- Finalizo com um agradecimento especial. Ao Eldes Ferreira de Lima. Por nossas afinidades. Pelo escritor que já é. Pela qualidade de sua literatura que me permitiu adentrar um pouco mais no seu universo. À sua escrita lúcida e viril, certamente uma inspiração. Pelos ensinamentos. Pela atenção dedicada a mim, mesmo durante os seus longos períodos de ausência: entre Bataguassu e Presidente Prudente, Florianópolis, São Paulo, Paris, Fortaleza, Campo Grande... Presidente Prudente. "Il y a toujours quelque chose d'absent qui me tourmente". (Camille Claudel)

Todas estas pessoas de algum modo influenciaram/influenciam a minha forma de encarar o mundo. Por isso merecem os meus sinceros agradecimentos. Vocês me dão as motivações/empolgações para que eu viva em função de oferecer o que há de melhor em mim nas relações que estabeleço e nas coisas que faço... 


\section{Índice}

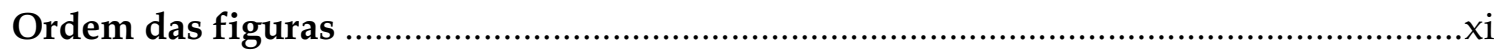

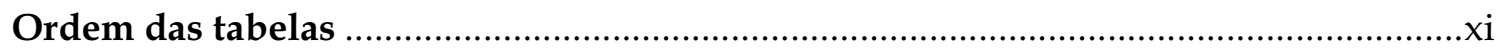

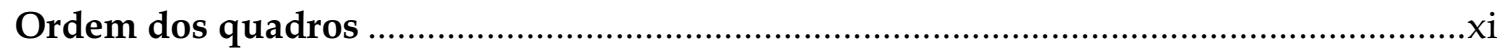

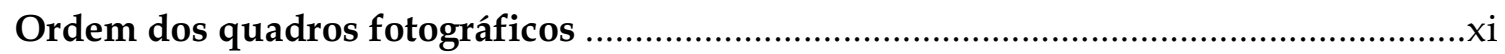

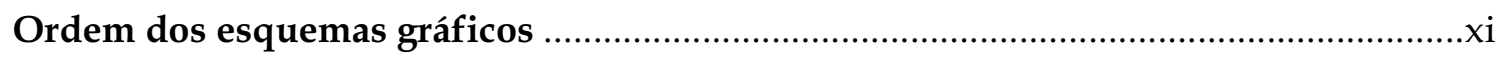

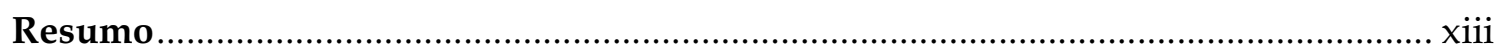

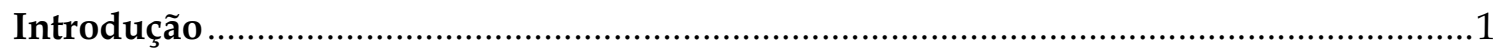

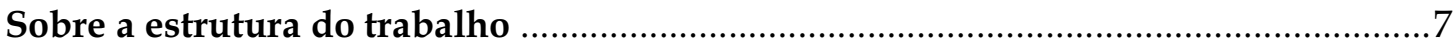

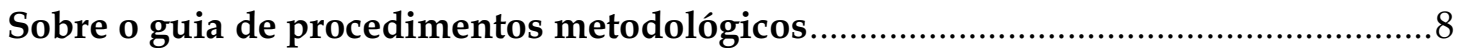

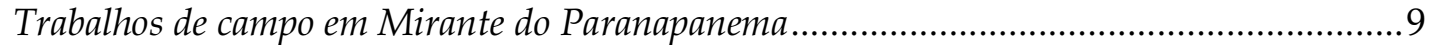

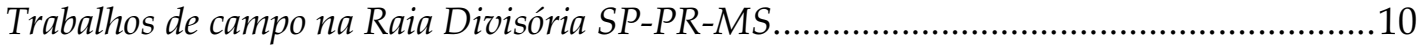

Visitas técnicas ao Ministério Público do Estado de São Paulo................................................10

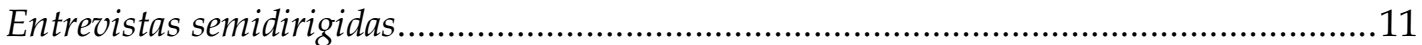

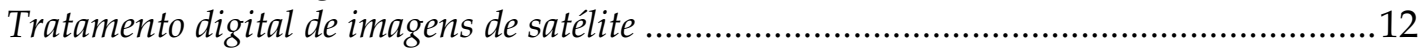

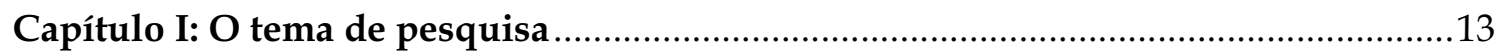

1) Notas introdutórias: as motivações da pesquisa ....................................................15

2) Um estudo sobre dinâmicas socioambientais .............................................................25

3) Vinculação ao Projeto Temático “Dinâmicas Socioambientais, Desenvolvimento Local e Sustentabilidade na Raia Divisória SP-PR-MS" ...................................................22

Capítulo II: Referencial teórico-metodológico

1) Notas introdutórias: o sistema GTP (Geossistema, Território, Paisagem) como novo projeto geográfico para a análise da interface sociedade-natureza ...............................32

2) Um sentido para a Geografia na análise da relação sociedade-natureza ....................34

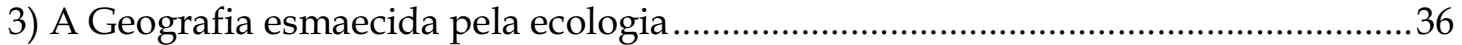

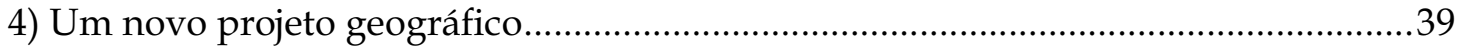

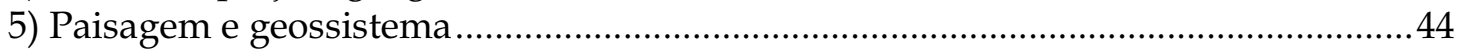

6) Um novo projeto geográfico: o sistema GTP (Geossistema, Território, Paisagem)..48

7) GTP: um filtro de linguagem ou chave conceitual para entrada na análise da

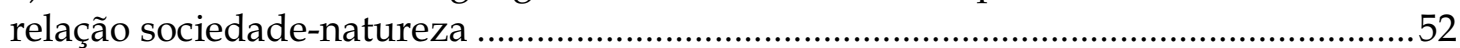

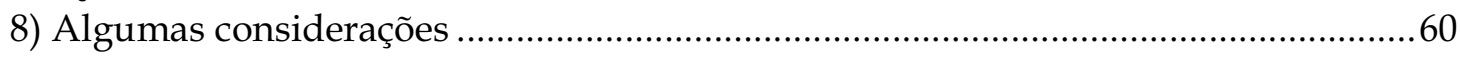

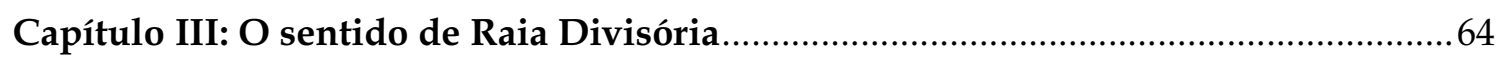

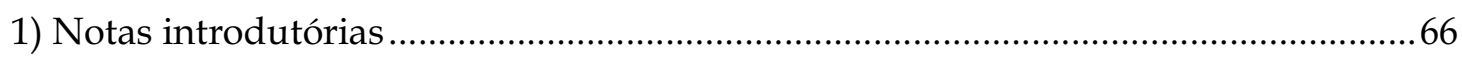




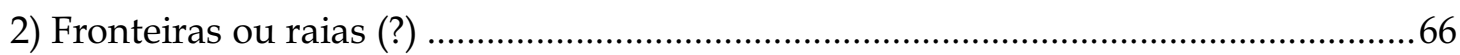

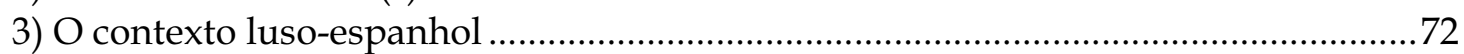

4) A Raia Divisória São Paulo-Paraná-Mato Grosso do Sul ..........................................76

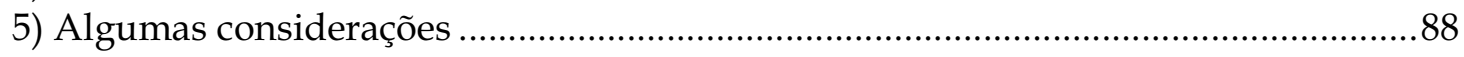

Capítulo IV: As dinâmicas socioambientais em Mirante do Paranapanema ................99

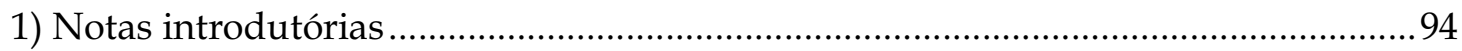

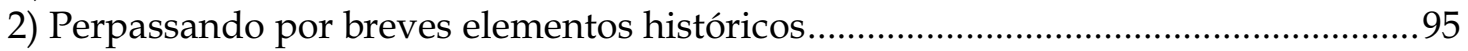

3) As dinâmicas socioambientais e suas singularidades paisagísticas ........................100

4) GTP: um filtro de linguagem ou chave conceitual para leitura das dinâmicas socioambientais em Mirante do Paranapanema........................................................120

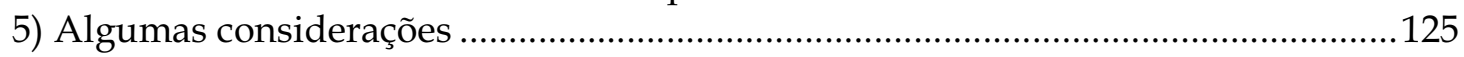

Capítulo V: A bacia do ribeirão Santo Antônio na perspectiva dos seus moradores 130

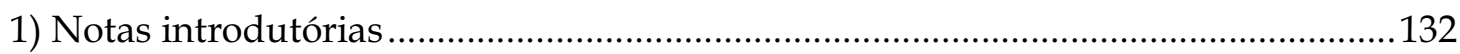

2) Meio ambiente, suas paisagens e seus atores: possibilidades de análise a partir da

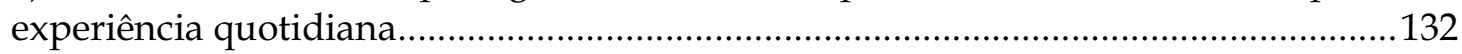

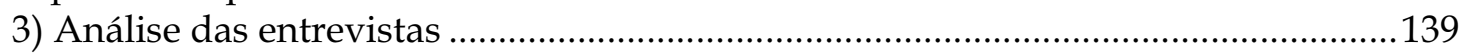

4) As representações paisagísticas na bacia do ribeirão Santo Antônio .........................150

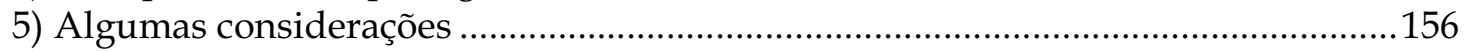

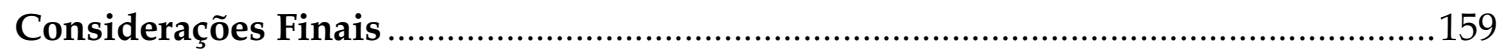

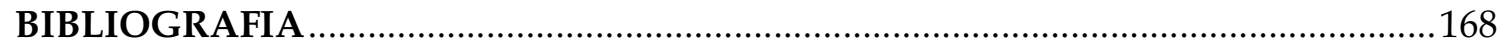




\section{Ordem das figuras}

1: Localização de Mirante do Paranapanema, 15

2: Localização da Raia Divisória SP-PR-MS, 78

3: Classificação do uso do solo em Mirante do Paranapanema (1985), 97

4: Classificação do uso do solo em Mirante do Paranapanema (1995), 98

5: Classificação do uso do solo em Mirante do Paranapanema (2005), 99

6: Localização da bacia do ribeirão Santo Antônio, 102

7: Distribuição espacial das singularidades paisagísticas em Mirante do Paranapanema, 115

\section{Ordem das tabelas}

1: Dados populacionais, por faixa etária, em Mirante do Paranapanema, 23

2: Possibilidades de leituras geográficas de fenômenos a partir do sistema GTP, 59

3: Evolução da população de municípios da região Noroeste do Paraná, 82

\section{Ordem dos quadros}

1: Classificação escalar da análise geográfica conforme a proposta geossistêmica de Bertrand (1968), 47

2: Formação territorial da Raia Divisória, 85

3: Singularidades paisagísticas diretamente observáveis no território de Mirante do Paranapanema, 114

4: Questionário aplicado aos moradores da bacia do ribeirão Santo Antônio, 141

\section{Ordem dos quadros fotográficos}

1: Aspectos de ribeirões, margens e nascentes no município de Mirante do Paranapanema, 116

2: Grande propriedade em Mirante do Paranapanema, antes e durante o plantio da cana-de-açúcar, $\mathbf{1 1 7}$

3: Aspectos de assentamentos rurais de reforma agrária e do bairro rural Colônia Branca, 118

4: Ícones da desterritorialização, 119

5: Residências de moradores na bacia do ribeirão Santo Antônio, 152

6: Aspectos das propriedades rurais localizadas na bacia do ribeirão Santo Antônio, 153

7: Imagens representativas de acontecimentos importantes na vida dos moradores da bacia do ribeirão Santo Antônio, 154

8: Representações de paisagens que deixarão de existir na opinião dos moradores da bacia do ribeirão Santo Antônio, 155

\section{Ordem dos esquemas gráficos}

1: Elementos (des)estruturantes do território-paisagem em Mirante do Paranapanema, 6

2: Fluxos de atividades em Mirante do Paranapanema, 22

3: Filtro de linguagem (ou chave conceitual) GTP, 53

4: Diferentes significados do conceito de natureza a partir da varredura semântica no sistema GTP, 54

5: "Filtragem" (ou "abertura") do conceito de sociedade no sistema GTP, 55

6: "Filtragem" (ou "abertura") da noção de impacto no sistema GTP, 56

7: "Filtragem" (ou "abertura") do conceito de relevo no sistema GTP, 57 
8: "Filtragem" (ou "abertura") da categoria tempo no sistema GTP, 58

9: Representação do sistema GTP, conforme a proposta de Georges Bertrand, 60

10: "Leitura GTP" das dinâmicas socioambientais em Mirante do Paranapanema Ocupação, 120

11: "Leitura GTP" das dinâmicas socioambientais em Mirante do Paranapanema Desmatamento, $\mathbf{1 2 1}$

12: "Leitura GTP" das dinâmicas socioambientais em Mirante do Paranapanema Agricultura, 122

13: "Leitura GTP" das dinâmicas socioambientais em Mirante do Paranapanema Pastagens, 123

14: "Leitura GTP" das dinâmicas socioambientais em Mirante do Paranapanema - Baixa dinâmica territorial, 124

15: Convergência de diferentes olhares sobre o território e a paisagem, 138

16: Relação sociedade-meio-ambiente (esquema simplificado), 164

17: Relação sociedade-meio-ambiente em Mirante do Paranapanema, 165 


\section{Resumo}

Com este trabalho apresentamos nossas análises sobre as dinâmicas socioambientais no município de Mirante do Paranapanema, localizado no Sudoeste Paulista ou Pontal do Paranapanema que, por sua vez, está inserido em um recorte territorial/regional mais amplo, ou seja, a Raia Divisória São Paulo-Paraná-Mato Grosso do Sul. Partimos do principio geral de que o estudo do meio ambiente no âmbito da ciência geográfica deve ser conduzido por uma perspectiva territorial. Então, tomamos o sistema teóricometodológico elaborado por Georges Bertrand para abordarmos os fenômenos híbridos (entre sociedade e natureza) no referido município: o sistema GTP (GeossistemaTerritório-Paisagem). A partir deste referencial, adotamos um guia de procedimentos metodológicos baseado em: i) trabalhos de campo em Mirante do Paranapanema; ii) trabalhos de campo na Raia Divisória SP-PR-MS; iii) visitas técnicas ao Ministério Público do Estado de São Paulo; iv) realização de entrevistas semidirigidas; v) tratamento digital de imagens de satélite. A operacionalização de cada um dos itens deste guia nos possibilitou identificar singularidades paisagísticas em Mirante do Paranapanema e desenvolver nossas análises sobre as mesmas tendo-se em vista as múltiplas determinações inerentes ao processo de produção e reprodução do território e de sua (s) paisagem (ens) como expressão das dinâmicas socioambientais que existem na área de estudo.

Palavras-chave: GTP (Geossistema-Território-Paisagem), meio ambiente, dinâmicas socioambientais, singularidades paisagísticas, Mirante do Paranapanema. 


\section{Introdução}




\section{soca}

"O trabalho de pesquisa impõe certos recortes.

Entre a materialidade e a abstração. Entre o que é físico e o que é idéia. Entre o espaço e a teoria. $O$ desenvolvimento de um trabalho acadêmico precisa ser operacionalizado. A busca pela coerência entre

o que se vê e o que se pensa (e vice-versa)é constante".

(Reginaldo José de Souza)

8OC 
Bem sabemos que o tratamento de uma temática complexa, tal como a ambiental ou socioambiental, não é tarefa simples. A discussão sobre o meio ambiente na Geografia é estimulante e desafiadora. Por este motivo o que poderia ser árduo se torna, na realidade, um prazer.

Multiplicidade de olhares. Pesquisas. Abordagens. Geógrafos e suas geografias. Existe uma profusão de elementos que convergem e/ou divergem na composição do cenário acadêmico cuja trama expressa é a busca por conceitos ou categorias, amplamente aceitos e sedimentados, aos estudos do meio ambiente.

Um meio ambiente que reclama sua outra metade por muito tempo perdida? Talvez esquecida. E ao que nos parece, vem sendo gradualmente relembrada. Isto porque a consciência sobre a ineficácia das divisões/dicotomias se expande nos dias de hoje.

Assim, o meio do termo meio ambiente não pode mais ser traduzido como fração (conforme o discurso ambientalista mais radical). E se ainda persistir este tipo de leitura, desde já salientamos (porque sinceramente acreditamos) que ela pode significar um erro.

Porque o meio deve ser lido, a nosso ver, como possibilidade-condição-intervenção. É a forma de relação entre a sociedade e tudo aquilo que ela toma para si como recurso que julga necessário à sua (re)produção. Neste sentido, jamais meio ambiente seria metade de alguma coisa. A não ser que o foco da discussão sobre a temática seja erroneamente desviado para um inoperante jogo de palavras.

Apenas uma breve ressalva para introduzirmos o leitor ao presente trabalho...

Breve ressalva, porém necessária.

Como dissemos, há uma profusão de enfoques no que diz respeito a esta temática. Adentramos nesta onda cientes dos desafios - aos quais nos submetemos pelo próprio desejo. Eles nos impelem à superação. O espírito de superação é condição sine qua non a todos que se lançam à tarefa de compreender certos aspectos essenciais da realidade em que vivemos. Certamente este trabalho pretende ser uma contribuição aos 
debates sobre a temática socioambiental na ciência geográfica entre tantos outros que já existem ou estão em processo de elaboração.

Aqui apresentaremos nossa concepção de Geografia voltada para a análise do meio ambiente. Nossa porque não consideramos que ela se restringe a apenas uma única abordagem. Exporemos aqui uma forma de encarar certos fenômenos a partir do leque de leituras que realizamos e as conseqüentes e inevitáveis interpretações de nossa parte.

O trabalho de pesquisa impõe certos recortes. Entre a materialidade e a abstração. Entre o que é físico e o que é idéia. Entre o espaço e a teoria. O desenvolvimento de um trabalho acadêmico precisa ser operacionalizado. A busca pela coerência entre o que se vê e o que se pensa (e vice-versa) é constante.

Princípios básicos de pesquisa devem ser considerados. Definições prévias. Posteriormente, um “objeto". E daí novos desafios emergem. Porque cada vez mais tomamos consciência de que os "objetos" sobre os quais debruçamos análises não são tão objetivos como já pretenderam concepções que se desdobraram a partir de abordagens separativas.

Os "objetos" também possuem dimensões abstratas. Os "objetos" são produzidos e transformados por sujeitos. Em escalas, formas e níveis diferenciados todos os sujeitos podem transformar a realidade de alguém ou de alguma coisa. Nestas imbricações, territórios emergem, por exemplo. Como expressões de algum tipo de relação de poder. Pessoas sobre pessoas. Sociedade sobre natureza e... Natureza sobre sociedade! Afinal, as dinâmicas naturais não são totalmente controláveis pela pretensão humana.

Assim, delineamos um dos princípios norteadores desta pesquisa: a complexidade inerente à questão socioambiental. Nós consideramos que a dimensão e magnitude das problemáticas ambientais serão sempre proporcionais ao tempo de permanência da humanidade sobre o planeta e de uma organização social cuja lógica de reprodução é baseada na extração excessiva de recursos da natureza sem preocupações conservacionistas realmente coerentes. 
A partir deste princípio geral fomos levados a considerar a dimensão territorial do meio ambiente para dar sustentação geográfica ao nosso estudo. Mas não seria redundante tratar do meio ambiente territorializado? Formação territorial já não pressuporia meio ambiente e vice-versa? Talvez sim. Porém, nem sempre isto que se parece com uma redundância foi/é percebido e devidamente trabalhado no âmbito da própria Geografia ou de outra (s) ciência (s).

Então a redundância se descaracteriza enquanto tal. E a Geografia, que tradicionalmente transita entre o campo naturalista e social, é convidada a contribuir ao debate sobre este tema, tanto em termos científicos quanto pedagógicos: ou seja, reiterar-disseminar-esclarecer (a todo instante) a idéia de que a sociedade está na natureza, mas também a natureza está na sociedade - os territórios (e suas paisagens) são manifestações desta hibridação.

Neste sentido, apresentamos esta dissertação. Resultado de nossa pesquisa no âmbito do curso de Mestrado do Programa de Pós-Graduação em Geografia da FCTUNESP. Um trabalho acadêmico que, assim como outros, foi operacionalizado a partir dos recortes anteriormente mencionados (teórico e espacial).

Antes de tudo, optamos por um determinado referencial teórico. A abordagem GTP (Geossistema, Território, Paisagem) de Georges Bertrand (2002, 2007). Consideramos que este sistema teórico-metodológico se presta à varredura conceitual lógica e hierarquizada de toda a terminologia utilizada no tratamento da questão socioambiental. Introdutoriamente podemos definir o sistema GTP pela seguinte combinação:

- $\quad$ O Geossistema é a fonte (source), o potencial geoecológico, permitindo a compreensão da estrutura e funcionamento biofísico de um espaço geográfico inclusive seus níveis de antropização;

- $\quad$ O Território, é a entrada socioeconômica (ressource) a partir do qual se tem a possibilidade de compreender as repercussões da sociedade na organização e funcionamento do espaço considerado; 
- A $\underline{\text { Paisagem }}$ é a entrada sociocultural, de tempo longo e identitário (ressourcement), que se presta para avaliar como as ações das sucessivas sociedades se materializam no território para construir as sucessivas paisagens.

Portanto, o sistema teórico-metodológico proposto por Bertrand é composto por três categorias híbridas. Por isto ele é uma possibilidade de reflexão epistemológica para a Geografia. Cada uma destas categorias reagrupa outras categorias e noções referentes à temática socioambiental de maneira integrada e numa hierarquia crescente. As hierarquizações não conferem graus de valor mais ou menos elevados às categorias, termos e noções utilizadas para análise dos fenômenos entre sociedade e natureza. Este assunto será desenvolvido no capítulo referente ao nosso embasamento teóricometodológico conforme se verificará logo mais.

A partir da opção por este referencial, definimos a nossa área de estudo específica, ou seja, o município de Mirante do Paranapanema. Um território que atualmente apresenta uma série de singularidades paisagísticas que nos remetem a pensar nos impactos socioambientais cuja origem está no próprio processo da sedimentação histórica do município baseado na utilização agrícola predatória conforme o seguinte esquema:

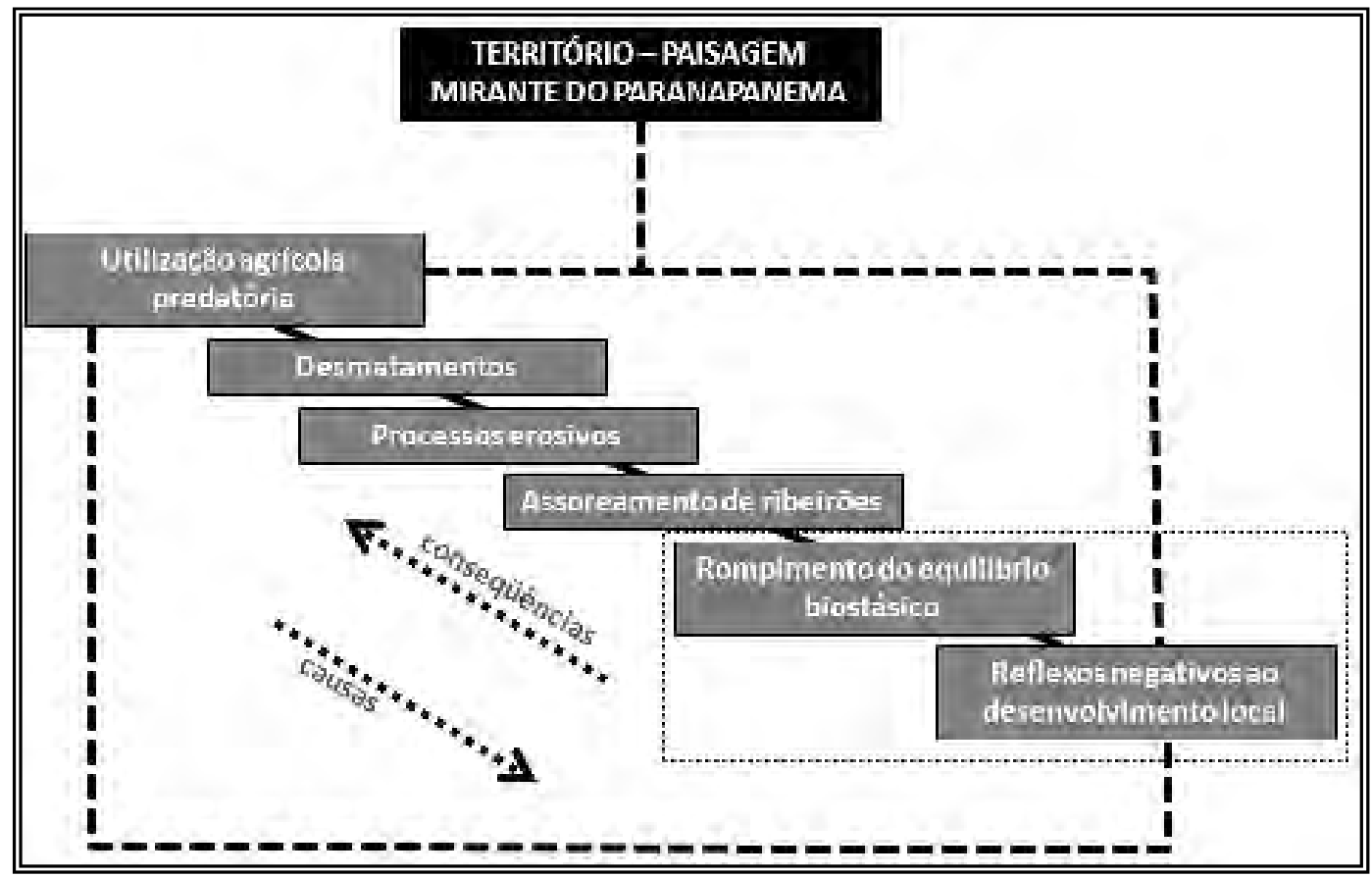

Esquema 1: Elementos (des)estruturantes do território-paisagem em Mirante do Paranapanema. A leitura pode ser realizada em duplo sentido: um elemento como causa do subseqüente ou como conseqüência do anterior. (Org.: Reginaldo J. Souza) 
A estrutura territorial e paisagística do município analisado é composta por uma série de elementos/eventos que se desencadearam ao longo de sua história e, nos dias de hoje, se refletem negativamente no desenvolvimento local e geram impactos socioambientais que motivaram e justificaram a elaboração desta pesquisa.

Os elementos expostos no esquema anterior nos conduziram a estabelecer como objetivo deste trabalho o estudo do meio ambiente territorializado e representado pela perspectiva da paisagem, tomando como ponto de partida o referencial bertrandiano para desenvolver a análise sobre as dinâmicas socioambientais em Mirante do Paranapanema. Ou seja, uma análise voltada para as relações existentes entre os fenômenos naturais e sociais na escala do município que o caracterizam como um território que atualmente reclama por um modelo de desenvolvimento local capaz de beneficiar sua população de maneira geral e reverter o estado de degradação de sua estrutura geoecológica.

Expostas estas notas introdutórias, sumariamente apresentamos a estrutura desta dissertação e, logo após, o guia de procedimentos metodológicos que nos permitiu operacionalizar a análise do objeto de estudo.

\section{Sobre a estrutura do trabalho}

Optamos por organizar o trabalho em basicamente cinco capítulos gerais. No primeiro capítulo, "O tema de pesquisa", apresentamos detalhadamente as motivações que nos levaram ao estudo sobre as dinâmicas socioambientais no município em questão.

O segundo capítulo "Referencial teórico-metodológico" traz uma discussão sobre a abordagem da relação sociedade-natureza no âmbito da Geografia e das possibilidades de análise da questão socioambiental (complexa por excelência) por meio do referencial propugnado por Georges Bertrand, tendo-se como base o sistema GTP (Geossistema, Território, Paisagem) para elaboração de estudos sobre o meio ambiente territorializado. 
Nosso trabalho vincula-se ao Projeto Temático “Dinâmicas socioambientais, desenvolvimento local e sustentabilidade na Raia Divisória São Paulo-Paraná-Mato Grosso do Sul", coordenado pelo Professor Messias M. dos Passos e financeiramente apoiado pela Fundação de Amparo à Pesquisa do Estado de São Paulo (FAPESP). Desta forma, tivemos necessidade de aprofundar a compreensão sobre o significado e importância deste território fronteiriço onde está inserido Mirante do Paranapanema. Para apresentar nossa concepção sobre a temática fronteiriça, inserimos o capítulo "O sentido de Raia Divisória".

Posteriormente, trouxemos à tona a abordagem sobre as dinâmicas socioambientais em Mirante do Paranapanema que foi guiada por elementos teóricometodológicos de Georges Bertrand. As dinâmicas socioambientais neste município possuem certas singularidades paisagísticas interessantes à análise geográfica. Este, portanto, é o nosso quarto capítulo: "Mirante do Paranapanema: dinâmicas socioambientais".

Finalizamos a dissertação com o capítulo "A bacia do ribeirão Santo Antônio sob a perspectiva dos seus moradores", onde apresentamos análise sobre as formas como os moradores da área apreendem seu espaço de vivência. Este capítulo resultou da realização de entrevistas semidirigidas onde tomamos por objetivo capturar elementos que nos possibilitassem entender aquilo que Bertrand chama de "cruzamento de diferentes olhares" sobre um território e a sua paisagem, de modo que as diferentes percepções dos indivíduos nos dão maiores subsídios para entender suas insatisfações e aspirações com relação ao lugar onde vivem.

\section{Sobre o guia de procedimentos metodológicos}

O guia de procedimentos metodológicos que adotamos conta com os seguintes itens:

i) Trabalhos de campo em Mirante do Paranapanema;

ii) Trabalhos de campo na Raia Divisória SP-PR-MS;

iii) Visitas técnicas ao Ministério Público do Estado de São Paulo; 
iv) Realização de entrevistas semidirigidas;

v) Tratamento de imagens de satélite por meio de software específico.

\section{Trabalhos de campo em Mirante do Paranapanema}

Realizamos seis trabalhos de campo na área de estudos (abril/maio, outubro/novembro de 2008; abril/junho de 2009) de modo que os dois últimos nós dedicamos à realização de entrevistas semidirigidas com moradores da bacia do ribeirão Santo Antônio.

Os trabalhos de campo geralmente tiveram um cunho de prospecção territorial (exceto os dois últimos). Eles se prestaram à obtenção de referências paisagísticas in loco. O que tratamos como referências paisagísticas são, na realidade, singularidades que denotam as características das dinâmicas socioambientais no município analisado, ou seja:

- margens de ribeirões que atualmente não apresentam mata ciliar preservada ou até mesmo a total ausência desta;

- vertentes com graves processos erosivos que expõem a fragilidade do solo aliada às práticas agrícolas pouco conservacionistas;

- ribeirões assoreados;

- ícones de desterritorialização no município (prédios abandonados de antigas empresas beneficiadoras de algodão).

As singularidades foram fotografadas e georreferenciadas por meio de equipamento GPS (Sistema de Posicionamento Global), para que posteriormente nos permitisse desenvolver a análise em sinergia ao referencial teórico-metodológico e às informações obtidas por meio das visitas técnicas que realizamos à Prefeitura Municipal e ao ITESP (durante os trabalhos de campo), bem como as visitas ao Ministério Público do Estado de São Paulo. 
Trabalhos de campo na Raia Divisória SP-PR-MS

Realizamos duas prospecções territoriais na Raia Divisória SP-PR-MS. A primeira prospecção ocorreu no mês de março de 2008 durante três dias de viagem. Partimos de Maringá-PR até o município de Terra Rica-PR, posteriormente, do município de Rosana-SP até Mirante do Paranapanema-SP.

A segunda prospecção ocorreu no mês de novembro de 2008 em três dias de viagem. Partimos do município de Mirante do Paranapanema-SP até Euclides da Cunha Paulista-SP e, posteriormente, do município de Terra Rica-PR a Porto Rico-PR até o retorno a Mirante do Paranapanema.

Ao longo dos trajetos, entramos em contato com alguns órgãos públicos dos municípios visitados (Prefeituras Municipais e, no caso de Mirante do Paranapanema, o Instituto de Terras do Estado de São Paulo - ITESP), no intuito de obter informações (dados sobre estrutura fundiária e projetos que contemplem dinamização das economias locais e/ou minimização de impactos ao meio ambiente) pertinentes ao desenrolar tanto das pesquisas no âmbito do Projeto Temático ao qual se vincula este trabalho bem como da nossa análise a respeito das dinâmicas territoriais na Raia SP-PRMS que organizamos em formato de capítulo na presente dissertação.

\section{Visitas técnicas ao Ministério Público do Estado de São Paulo}

Nos meses de abril, junho e agosto de 2008, realizamos visitas técnicas ao Centro de Apoio Operacional das Promotorias de Justiça de Urbanismo e Meio Ambiente Área Regional de Presidente Prudente (C.A.O.A.R.P.P.).

A partir destas visitas coletamos informações sobre o andamento de processos referentes à degradação ambiental em propriedades rurais no município analisado.

Entramos em contato com 10 pareceres técnicos ${ }^{1}$ elaborados a partir de vistorias em propriedades rurais que foram autuadas devido a denúncias por danos ambientais.

\footnotetext{
${ }^{1}$ Assinados por Marcos Norberto Boin, assistente técnico do C.A.O.A.R.P.P.
} 
Estas informações, juntamente àquelas obtidas nos trabalhos de campo, contribuíram significativamente ao desenvolvimento desta pesquisa.

\section{Entrevistas semidirigidas ${ }^{2}$}

No intuito de aprofundarmos a nossa análise sobre as dinâmicas socioambientais em Mirante do Paranapanema, realizamos entrevistas semidirigidas junto aos moradores da bacia do ribeirão Santo Antônio na área rural do município.

As entrevistas se prestaram à obtenção de informações sobre as diferentes formas dos moradores desta área reagirem às paisagens do lugar em que vivem, as visões sobre as atuais condições de vida em suas propriedades e suas memórias sobre o passado em comparação ao que é vivenciado nos dias atuais.

A escolha dos entrevistados se deu a partir de uma reunião com os membros da Associação dos Produtores Rurais da Bacia do ribeirão Santo Antônio. Nesta reunião foram indicados alguns moradores do local, entre os próprios associados, conforme os seguintes critérios que estabelecemos:

- Idade (moradores acima dos 40 anos de idade);

- Maior tempo de moradia no município;

A opção pelos habitantes mais antigos esteve relacionada ao nosso objetivo em analisar sua percepção das transformações históricas da paisagem.

Para a realização das entrevistas, elaboramos um questionário composto por basicamente 13 perguntas a serem feitas aos moradores da referida bacia. (conferir quadro de questões, pg.141)

As questões foram estabelecidas conforme nossos objetivos em apreender a percepção da paisagem, o sentimento de identidade, enfim, a ligação que os moradores têm com o seu lugar de vivência. É importante frisar que estas questões não

\footnotetext{
2 Utilizamos procedimento análogo ao de Renó (2009) em sua abordagem sobre "O Sertão Mineiro: um território em busca de suas paisagens e identidades". Em sua Tese de Doutorado, esta pesquisadora adotou a realização da entrevista semidirigida como estratégia para captação dos olhares da população como forma de retirar a paisagem de uma "aparente banalidade" e analisar os aspectos extraordinários apontados pelos entrevistados. (Cf. RENÓ, 2009, p.128)
} 
pretenderam - em nenhum momento das entrevistas - gerar respostas fechadas ou exclusivamente objetivas.

Gravamos todas as entrevistas em áudio, posteriormente as transcrevemos e analisamos os discursos dos moradores. Além das entrevistas, também realizamos um registro e tratamento fotográfico das principais representações paisagísticas na ótica dos entrevistados.

\section{Tratamento digital de imagens de satélite}

No intuito de reforçar a nossa análise sobre as dinâmicas socioambientais apreendidas pela paisagem, realizamos o tratamento digital de imagens LANDSAT 5 (Cena: p.223 r.075) obtidas do Instituto Nacional de Pesquisas Espaciais (INPE) dos anos de 1985, 1995 e 2005 considerando três etapas principais: análise visual, espectral e classificação do uso do solo.

Para a análise visual e espectral utilizamos a composição colorida (falsa cor) com as bandas 3, 4 e 5 (comprimento de onda do vermelho na faixa do visível do espectro eletromagnético, comprimento de onda do infravermelho próximo, comprimento de onda infravermelho médio, respectivamente).

Para a classificação das imagens, utilizamos as bandas 1, 2, 3, 4 e 5 no software Spring ${ }^{3}$ - versão 5.0.5, através dos procedimentos de segmentação das imagens por regiões $^{4}$ (grau de similaridade 10 e área -pixel- 20); e uso do classificador Bhattacharya. Consideramos as categorias mais relevantes ao desenvolvimento da análise, ou seja:

i) Áreas de pastagens;

ii) Áreas de cultivo agrícola;

iii) Áreas de vegetação;

iv) Áreas de solo exposto.

\footnotetext{
${ }^{3}$ SPRING: Integrating remote sensing and GIS by object-oriented data modelling" Camara G, Souza RCM, Freitas UM, Garrido I Computers \& Graphics, 20: (3) 395-403, May-Jun 1996.

${ }^{4}$ Requer interação com o usuário através de treinamento.
} 


\section{Capítulo I:}

O tema de pesquisa 


\section{soce}

"Uma sociedade faz mais do que simplesmente ocupar seu território; na verdade ela produz, na medida em que projeta sobre ele significados que são, necessariamente, resultantes de processos complexos. Por isto mesmo, a noção de território atualiza, de maneira candente, a pro6lemática entre natureza e sociedade...".

(Carlos Walter P. Gonçalves)

8003 


\section{1) Notas introdutórias: as motivações da pesquisa}

A proposta central do presente trabalho é o estudo sobre as dinâmicas socioambientais em Mirante do Paranapanema (ver figura 1), considerando a dimensão territorial e paisagística do meio ambiente. Optamos pelo estudo deste município por alguns motivos importantes que serão expostos em seguida.

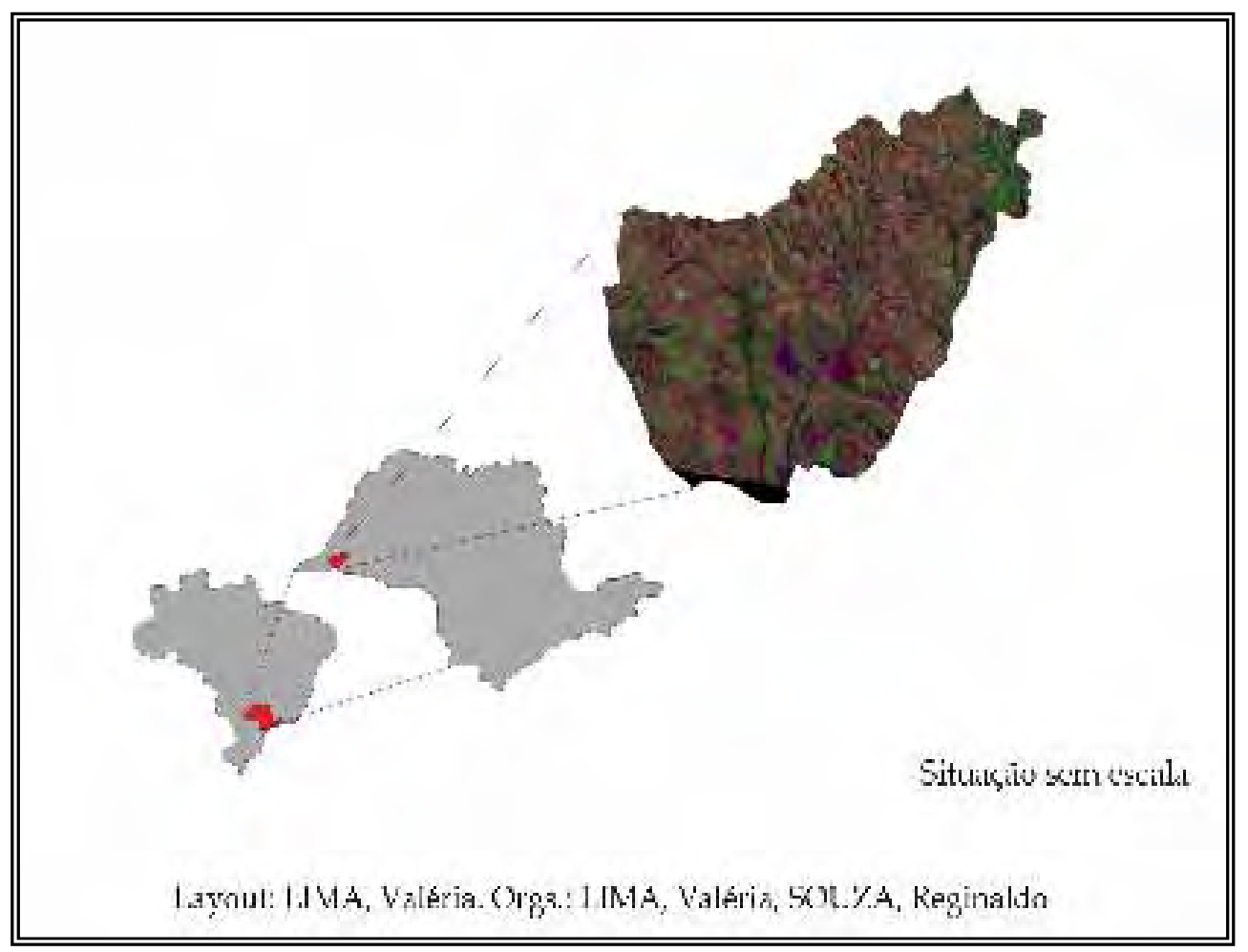

Figura 1: Localização de Mirante do Paranapanema/SP.

Mirante do Paranapanema atualmente apresenta uma variedade de elementos que nos remetem à discussão da problemática socioambiental no âmbito da ciência geográfica. Estes elementos dizem respeito a certas formas paisagísticas que são indicadoras de degradação ambiental no contexto de modelos de apropriação econômica do território que, certamente, são pouco coerentes às práticas produtivas mais conservacionistas.

Desde anos anteriores à sua emancipação político-admnistrativa (1953), a área do atual município já estava de certo modo "fadada" a um modelo de ocupação que mais tarde traria reflexos muito negativos tanto para a combinação e dinâmica dos elementos 
geoecológicos quanto ao próprio desenvolvimento local. Isto é, um modelo de ocupação que se estabelecia na região do Pontal do Paranapanema como um todo e tinha como princípio fundamental a derrubada da mata para a garantia da posse da terra de acordo com o espírito imediatista dos colonizadores e grileiros àquela época.

O Pontal do Paranapanema constituía-se, originalmente, numa paisagem relativamente uniforme, em equilíbrio biostásico ${ }^{5}$, podendo ser associado ao domínio dos mares-de-morros, embora fora de sua área mais típica, situada nas regiões cristalinas do Brasil Sudeste. É evidente que por se tratar de uma área periférica, com relevo tabuliforme suavemente convexizado, apresenta um potencial ecológico e uma exploração biológica um tanto distinto da existente na "área core" desse domínio morfoclimático. (Cf. PASSOS, 2006)

No Pontal do Paranapanema, como um todo, as ações antrópicas atuaram diversamente rompendo com o equilíbrio biostásico. Desta diversidade atuante sobre o conjunto paisagístico originalmente uniforme na região, surgiu uma espécie de mosaico de unidades de paisagem que se definiram conforme o uso destinado ao solo. A fronteira agrícola avançou e se estabeleceu, causando substanciais alterações que levaram a prejuízos ao potencial geoecológico e à população regional.

Tais acontecimentos, em si, já são motivos suficientemente capazes de justificar a nossa escolha quanto ao objeto de estudo definido. O município de Mirante do Paranapanema está inserido neste conjunto regional mais amplo que é o Pontal do Paranapanema e, por conseguinte, também apresenta sérios agravos ao meio ambiente. Inclusive "agravos", aqui, não apenas como sinônimo de danos ambientais, mas também no sentido de recursos judiciais contra estes mesmos danos que tramitam no Centro de Apoio Operacional das Promotorias de Justiça de Urbanismo e Meio Ambiente da Área Regional de Presidente Prudenté.

\footnotetext{
50 conceito de biostasia, na proposta de Georges Bertrand (1968), apóia-se nas formulações do edafólogo Erhart (1956). Este elabora a teoria da bio-resistasia no âmbito de suas análises sobre a constituição e destruição dos solos. Bertrand associa tais conceitos à dinâmica dos geossistemas e, assim, distingue seus diferentes estados de equilíbrio. O autor define geossistemas em biostasia como estáveis por serem recobertos com densa vegetação e, portanto, propiciarem a edafogênese. Por outro lado, geossistemas em resistasia apresentam certa instabilidade, com predomínio do desnudamento das formações litológicas e a morfogênese.

${ }^{6}$ Sobre este assunto, apresentamos maiores informações no capítulo IV.
} 
O referido município foi palco de um tipo de ocupação agrícola que provocou uma morfodinâmica muito agressiva do relevo, resultando em um rápido exaurimento do solo, com erosão e assoreamento dos córregos, ou seja, consubstanciando-se uma série de impactos ambientais que, de modo direto ou indireto, acabaram/acabam por se refletir na sociedade local.

Desta forma, temos em mãos outro motivo que nos guiou à escolha deste município em nossa pesquisa, sendo ele: a necessidade de estudarmos o meio ambiente sob a perspectiva territorial. Ou seja, do meio ambiente territorializado. Com vistas a analisarmos o modo pelo qual as dinâmicas socioambientais se materializaram na paisagem-território e se prestam, nos dias de hoje, como indicadores dos processos históricos e atuais da evolução (construção, desconstrução e reconstrução) da paisagem. Além de um motivo, também apresentamos o estudo do meio ambiente territorializado como nosso objetivo central de pesquisa, conforme mencionamos anteriormente.

A idéia de partir para o estudo do meio ambiente territorializado está vinculada a duas de nossas concepções a respeito da abordagem socioambiental na Geografia, sendo elas:

- A Geografia é uma interpretação social do território e;

- O termo meio ambiente é muito ambíguo e até mesmo confuso.

Mendonça nos alerta o seguinte:

Se na sociedade em geral o termo meio ambiente ou ambiente (environment, environnement), vitimado que foi pela inflação jornalística banalizou-se [...], no âmbito acadêmico-científico ele não passou impune a esse processo. Tais termos têm sido utilizados das mais diversas maneiras, mas, em boa parte das vezes, têm sido empregados como um processo industrial em que se colocam rótulos novos em produtos ultrapassados ou que não correspondem ao texto ali expresso. Assim, é preciso ter muito cuidado, pois os rótulos podem embelezar os produtos e expressar a vanguarda dos mesmos, mas podem também ser fortemente enganosos. (MENDONÇA, 2002, p.134, grifo nosso)

Encontramos no autor anteriormente mencionado uma tradução sobre a concepção de meio ambiente enquanto termo de certo modo confuso e passível de alguma utilização pouco consoante às aspirações científicas no contexto geográfico. 
Neste sentido, emergiu outro motivo que nos guiou à elaboração do projeto de pesquisa há dois anos e a apresentação de seus resultados neste momento. Ou seja, a preocupação em:

i) sustentarmos a abordagem socioambiental de acordo com o corpo teóricoconceitual da ciência geográfica e assim;

ii) não contrafazermos uma análise digressiva que abra ainda mais a definição de meio ambiente à confusão e à banalização.

Então, nós tomamos o município de Mirante do Paranapanema em sua dimensão territorial. Como espaço (com sua dimensão natural) apropriado e produzido por determinado grupo social conforme o processo de formação histórica do Pontal do Paranapanema que, por sua vez, está inserido em uma porção maior: a Raia Divisória São Paulo-Paraná-Mato Grosso do Sul.

Embora a região do Pontal do Paranapanema seja social e economicamente deprimida como um todo e tenha sediado um modelo de ocupação histórica que levou a certa homogeneidade fisionômica da paisagem (principalmente quando se observa o predomínio atual de áreas de pastagens, da retirada das matas ciliares e assoreamento dos córregos), é importante procurar sair de uma visão generalizante desta região e considerar as especificidades dos processos de degradação ambiental na escala dos municípios. Lembrando que tal degradação de modo direto ou indireto se reflete enquanto fator negativo na própria dinâmica socioeconômica municipal, legitimando-se como verdadeira degradação socioambiental.

Expusemos mais um dos motivos que nos levaram a escolha do referido município enquanto escala de análise em nossa pesquisa voltada à apreensão da problemática socioambiental: a necessidade de se considerar as características peculiares das ações antrópicas sobre seus elementos geoecológicos. Características estas que se diferem de alguns outros municípios localizados naquilo a que Passos (2007, p.17) denomina de "área core do Pontal", ou seja, um conjunto que se estende desde o ribeirão das Anhumas (na vertente do rio Paraná) e ribeirão do Engano ou Santo Antônio (na vertente do rio Paranapanema) - limite leste - até a confluência destes dois grandes rios - limite oeste. 
Mirante do Paranapanema localiza-se, por assim dizer, em uma área denominada "Grande Pontal" que também é composta pelos atuais municípios de Marabá Paulista e Sandovalina. (PASSOS, 2007, p.16) Em termos de substrato geológico, apresenta áreas de afloramento de arenitos do Grupo Bauru com solos que no passado (sobretudo após a década de 1940) possibilitaram exploração agrícola mais intensiva, baseada essencialmente na cultura do algodão e amendoim.

A magnitude dos reflexos desta destinação ao solo no passado é algo que se faz presente na paisagem do município nos dias de hoje. Os sinais de absoluta degradação não são apenas captados por nosso olhar sobre a paisagem como, também, são sentidos pela própria população residente na área rural, cuja percepção que têm sobre o ambiente em que vivem lhes permite afirmações como "isto aqui é um cemitério, não tem pessoas, não tem lavouras, todos foram embora", "tudo está se acabando", "a pastagem é o que restou", "não é mais possível ter lavouras" etc.

Bertrand (2007, p.89) menciona a importância de nos atermos à circularidade do tempo, entre as fenologias naturais e os ritmos calendários, ao falarmos sobre o meio ambiente. "Hoje, na geografia, não existem mais estações! Como falar de meio ambiente e de paisagem se perdemos o sentimento da duração e esquecemos a cor do tempo?". A paisagem desestruturada de Mirante do Paranapanema se destaca, conforme observado em nossos trabalhos de campo, nas épocas em que "oficialmente" estamos entre o último mês do período de outono e início do inverno.

Há uma palidez nos tons de verde que colorem a paisagem. As gramíneas e as folhas das árvores aproximam-se mais aos tons amarelados perante a relativa ausência de chuvas no período. O produtor na pequena propriedade preocupa-se com a queda dos preços do leite no mercado. A pastagem seca e ruim, associada aos processos erosivos e assoreamento dos córregos, inibe a produção leiteira. A cor da estação remete a pensar na queda da capacidade produtiva dos pastos, na diminuição dos ganhos, enfim, nos prejuízos econômicos da população do campo.

Em entrevistas que realizamos a pequenos proprietários, durante trabalho de campo na área rural do município, percebemos sua nostalgia com relação a um passado no qual era possível trabalhar com a lavoura e como a economia local era muito mais 
dinâmica do que no presente. A população, muitas vezes, tem certa consciência sobre o processo de degradação provocado pelo uso inadequado do solo, porém, há também ausência de recursos para se promover melhorias na propriedade em se tratando de aplicação de técnicas mais apropriadas de manejo.

Um morador da área rural do município expressou seu pessimismo com relação à atual condição dos recursos naturais e futuro da área onde vive. Quando nós o entrevistamos, percebemos que ele não acredita na possibilidade de recuperação dos ribeirões assoreados diante da baixa fertilidade do solo e conclui que o trabalho na lavoura não é mais possível para o pequeno proprietário.

Perante estas observações de campo, nos remetemos a uma passagem de Bertrand sobre o espaço rural:

O espaço rural, no sentido amplo, é o meio natural organizado para a produção agrícola, animal ou vegetal, pelos grupos humanos que fundam sobre sua totalidade ou sua parte, sua vida econômica e social. [...] o espaço rural não existe fora das condições naturais. Ele é uma realidade ecológica. Por definição, ele comporta uma parte maior de elementos naturais ou diretamente derivados do meio natural: relevo, clima, solo, águas, vegetais, animais. Todavia seus componentes naturais não podem ser impostos como uma dádiva prévia, mas como uma realidade vivida, às vezes dominante, às vezes dominada, combatida e utilizada no interior de uma organização social e econômica. (BERTRAND, 2007, p.127)

[...] o espaço rural não é somente uma estrutura espacial autônoma, é também, um sistema integrado e funcional no qual todos elementos são dinamicamente solidários uns com os outros, portanto indissociáveis. (BERTRAND, 2007, p. 141, grifo nosso)

Traçando um paralelo entre esta reflexão sobre o espaço rural de um modo geral e como este está (des)organizado em Mirante do Paranapanema, infelizmente o que observamos é a extrema degradação existente neste território, fruto de desequilíbrios entre ações das sucessivas sociedades que sobre ele atuaram e a capacidade de suporte das suas potencialidades geoecológicas. No caso deste município, não podemos interpretar que o seu espaço rural é um sistema integrado onde todos os elementos são dinamicamente solidários. Ao contrário: o que percebemos é uma franca desintegração. Homem e natureza sentem os reflexos desta relação dissimétrica. Os prejuízos maiores incidem direta e agressivamente sobre a sociedade local. 
A dinâmica dos fluxos de população e atividades no município aponta para este fato. Passos (2007, p.308) menciona três características de fluxos em momentos diferentes da história de Mirante do Paranapanema. Entre os anos de 1940 a 1960, os fluxos se deram de modo centrífugo a partir do núcleo urbano, ou seja, era o momento da ocupação efetiva do território, baseada no desmatamento e na agricultura.

No intervalo que segue de 1960 a 1980, o núcleo urbano tornou-se o receptor da população que deixou as atividades do campo, sobretudo com a decadência da cultura algodoeira e a expansão da pecuária.

Entre os anos de 1980 e 2000, o referido autor aponta para um processo de desterritorialização no qual as relações entre cidade e campo são afrouxadas e a população rural se desloca: os mais idosos permanecem no município enquanto a parcela mais jovem da população parte para outras cidades do interior de São Paulo (principalmente Presidente Prudente), capital e região Centro-Oeste. (ver esquema 2, pg.22) 


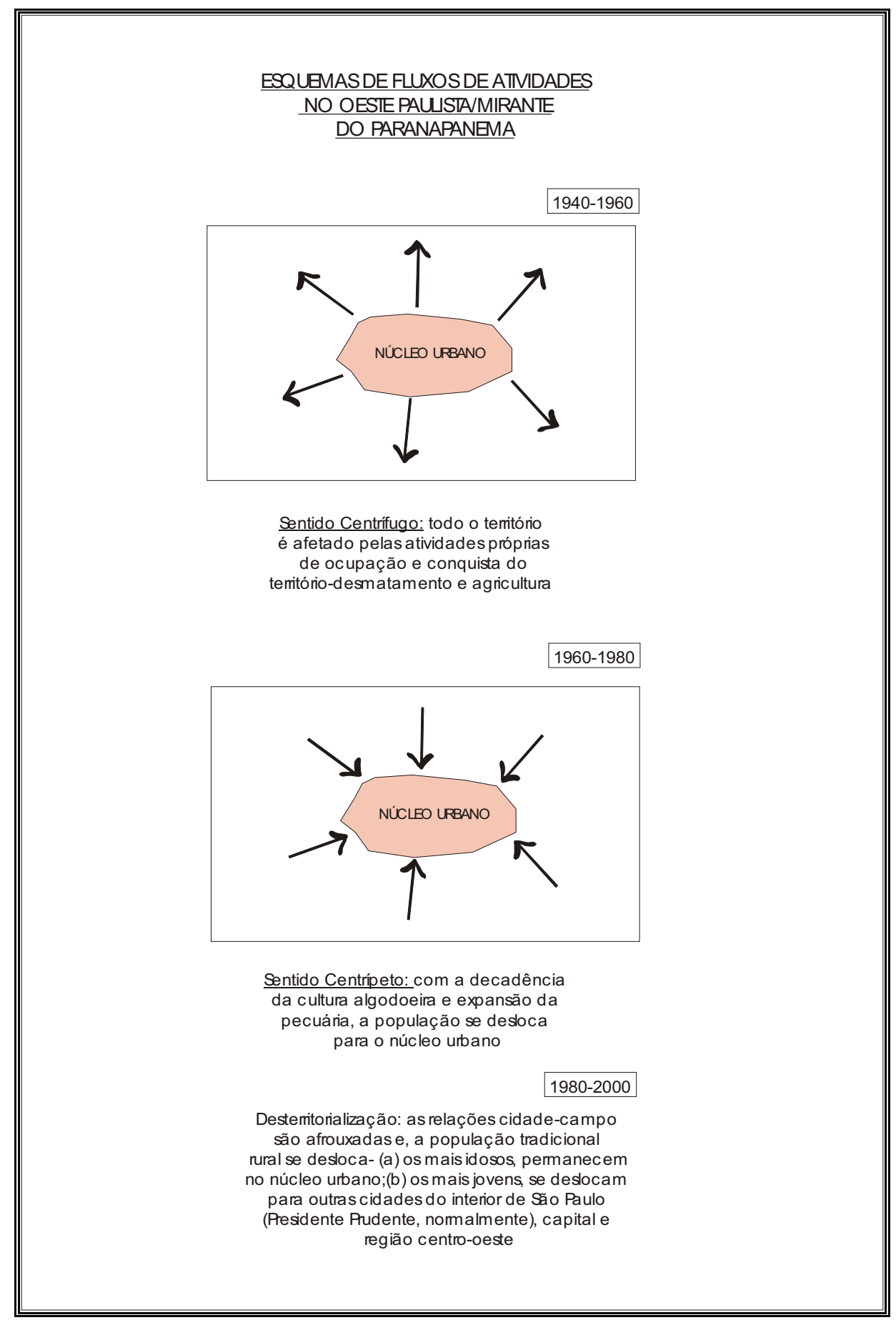

Esquema 2: fluxos de atividades em Mirante do Paranapanema. Fonte: Passos, 2005.

Os dados censitários do IBGE - referentes ao número de habitantes no município, por faixa etária - levantados entre os anos de 1970 e 2000 - nos remetem a esta realidade: 
Tabela 1: Dados populacionais, por faixa etária, em Mirante do Paranapanema-SP

\begin{tabular}{|c|c|c|c|c|}
\hline \multirow[b]{2}{*}{ Faixa Etária (anos) } & \multicolumn{4}{|c|}{ Número de Habitantes } \\
\hline & Censo 1970 & Censo 1980 & Censo 1991 & Censo 2000 \\
\hline De 0 a 4 & 3.579 & 2.021 & 1.521 & 1.297 \\
\hline De 5 a 9 & 3.758 & 2.025 & 1.667 & 1.452 \\
\hline De 10 a 14 & 3.217 & 2.187 & 1.753 & 1.634 \\
\hline De 15 a 19 & 2.324 & 1.971 & 1.638 & 1.649 \\
\hline De 20 a 24 & 1.722 & 1.325 & 1.431 & 1.325 \\
\hline De 25 a 29 & 1.537 & 1.012 & 1.264 & 1.124 \\
\hline De 30 a 34 & 1.261 & 879 & 1.096 & 1.200 \\
\hline De 35 a 39 & 1.087 & 812 & 874 & 1.215 \\
\hline De 40 a 44 & 1.033 & 714 & 777 & 874 \\
\hline De 45 a 49 & 769 & 660 & 687 & 1.013 \\
\hline De 50 a 54 & 519 & 589 & 582 & 731 \\
\hline De 55 a 59 & 431 & 408 & 537 & 769 \\
\hline De 60 a 64 & 282 & 317 & 471 & 566 \\
\hline De 65 a 69 & 155 & 240 & 363 & 562 \\
\hline De 70 a 74 & 108 & 156 & 229 & 333 \\
\hline De 75 a 79 & 49 & 59 & 153 & 253 \\
\hline Acima de 80 & 61 & 77 & 136 & 217 (até 99 anos)* \\
\hline Total do município & 21.909 & 15.459 & 15.179 & 16.213 \\
\hline
\end{tabular}

Fonte: SIDRA-IBGE. Org.: Reginaldo J. Souza

De um modo geral, houve uma queda significativa do total da população verificável nos censos de 1980, 1991 e 2000 quando comparados ao resultado referente a 1970. Considerando a população na faixa de idade que vai dos 20 aos 29 anos, percebese uma queda geral de 1970 para 2000, embora no censo de 1991 tenha apresentado um suave aumento; a soma total da população nesta faixa etária para cada ano é de 3.259 habitantes para 1970; 2.337, para 1980; 2.695 para 1991 e 2.449 para o ano 2000. Por outro lado, a população que está na faixa dos 60 anos de idade para mais, embora bem menor do que a população mais jovem, apresentou aumento significativo que nos permite deduzir as fragilidades do município, principalmente no que diz respeito à ausência de perspectivas futuras para os jovens no âmbito de empregos e na área da educação.

O esvaziamento populacional, a diminuição do número de habitantes jovens e o aumento do número de habitantes mais idosos, em Mirante do Paranapanema, nos remetem à essência de um problema de ordem estrutural: a errônea idéia de que a natureza se presta à exploração ilimitada pela sociedade. Entendemos ser este o cerne 
da questão, muito além da associação da mencionada dinâmica populacional aos reflexos negativos na economia do município provocados pelo declínio acentuado da agricultura e uso do solo mais direcionado à pecuária.

O "pecado original" volta-se ao modelo predatório da relação sociedadenatureza, onde a cultura do uso intensivo foi priorizada no seio de aspirações econômicas mais imediatistas dentro do contexto da colonização no Sudoeste Paulista como um todo. Ao que tudo indica, a ausência de atitudes com vistas à manutenção de menores dissimetrias entre utilização econômica e a capacidade de suporte dos elementos naturais que compõem o espaço rural norteou o município, historicamente, ao atual estado de degradação expresso por sua (s) paisagem (ens).

Este modelo predatório pode ser inferido a partir, por exemplo, dos dados apresentados pelo IBGE no censo agropecuário realizado no ano de 2006. A área total dos estabelecimentos agropecuários em Mirante do Paranapanema corresponde a 115.524 ha, sendo que dentro deste conjunto existem apenas 1.658 ha que se enquadram no item "Áreas de matas e florestas" definido pelo Instituto. De 2.288 estabelecimentos rurais no município, apenas 334 apresentam áreas de matas. Trata-se de uma diferença, no mínimo, alarmante...

Outros exemplos deste quadro de degradação estão nas redações de dez pareceres técnicos resultantes de vistorias realizadas em propriedades rurais, em Mirante do Paranapanema, por representantes do Centro de Apoio Operacional das Promotorias de Justiça de Urbanismo e Meio Ambiente - Área Regional de Presidente Prudente (C.A.O.A.R.P.P.).

Entramos em contato com esta documentação por meio de visitas técnicas ao Ministério Público do Estado de São Paulo e nela pudemos verificar que boa parte das autuações se deu devido a danos ambientais em áreas que são definidas, pela legislação vigente, como sendo de preservação permanente (APP): derrubada das matas ciliares, derrubada ou envenenamento de Reservas Legais, estabelecimento de assentamentos de reforma agrária sobre áreas de preservação etc. Ou seja, uma série de fatores que atualmente contribuem para piorar a situação dos elementos naturais no município e 
afastar para um futuro cada vez mais distante (quase utópico) as possibilidades de um verdadeiro desenvolvimento local sustentável.

Por todos estes aspectos apresentados, é possível afirmar que Mirante do Paranapanema, inscrito no conjunto regional do Pontal do Paranapanema e da própria Raia Divisória SP-PR-MS, forma uma espécie de palimpsesto naquele sentido atribuído por Santos (1997, p.66) à paisagem, sendo esta algo semelhante a uma escrita sobre a outra, um conjunto de objetos com idades diferentes, enfim, uma herança de muitos diferentes momentos.

\section{2) Um estudo sobre dinâmicas socioambientais}

O tema de nossa pesquisa, portanto, é de caráter socioambiental. Pretende-se chegar o mais próximo possível da interessante concepção de Francisco Mendonça sobre este tema:

[...] um estudo elaborado em conformidade com a geografia socioambiental deve emanar de problemáticas em que situações conflituosas, decorrentes da interação entre sociedade e natureza, explicitem degradação de uma ou de ambas. A diversidade das problemáticas é que vai demandar um enfoque mais centrado na dimensão natural ou na dimensão social, atentando sempre para o fato de que a meta principal de tais estudos e ações é a busca de soluções do problema, e que este deverá ser abordado a partir da interação entre estas duas componentes da realidade. (MENDONÇA, 2002, p.134, grifo nosso)

Nossa preocupação central é avaliar como as ações da sociedade se manifestaram historicamente em Mirante do Paranapanema; as formas paisagísticas que foram geradas no processo de (des)organização do território; os (des)arranjos na dinâmica dos elementos naturais; os reflexos destes (des)arranjos na vida social do município: como está a situação econômica dos produtores rurais, sobretudo dos pequenos? De que modo estes sujeitos avaliam as condições do espaço rural em que vivem? Como as políticas públicas atuais vêm contribuindo para a minimização de impactos negativos? 
Todos estes pontos serão contemplados e desenvolvidos ao longo deste texto tendo em vista a nossa postura teórico-metodológica guiada pelo sistema GTP (Geossistema-Território-Paisagem), elaborado pelo geógrafo Georges Bertrand ao longo de sua trajetória de pesquisa desde a década de 1960 aos dias atuais. O GTP pode se prestar à abordagem geográfica tanto como um sistema teórico quanto um ponto de partida à reflexão epistemológica sobre o meio ambiente. A análise integrada dos fenômenos na interface sociedade-natureza é a tônica desta tríplice conceitual e a tônica da nossa pesquisa é a tentativa de se chegar o mais próximo possível desta tendência teórica.

Um capítulo específico sobre nossa fundamentação teórica será apresentado mais adiante.

É pertinente esclarecermos, desde já, que nossas acepções acerca do saber e fazer geográficos não nos permite enquadrar nossa pesquisa em setores específicos. Em nenhum momento pretendemos esgotar uma análise guiada exclusivamente por princípios de Geografia Física ou por princípios de Geografia Humana, separadamente.

O nosso trabalho prioriza, antes de qualquer coisa, a abordagem de uma problemática que está posta na realidade. Uma problemática que, por si, já possui sua própria geografia antes mesmo que um geógrafo a apreenda. E é justamente por isto que merece nossa atenção enquanto pesquisadores, desde o momento em que procuramos entender de modo mais aprofundado o jogo de relações que está por trás da aparência dos fenômenos, passando pelo levantamento de dados, elaboração de críticas sobre o atual estado de coisas até, finalmente, a tentativa de apontarmos caminhos que sejam capazes de contribuir à minimização dos problemas analisados.

Análises nas quais o enfoque sobre a materialidade (elementos naturais e construções humanas, enfim, formas paisagísticas), imaterialidade (projeções subjetivas/intersubjetivas individuais ou coletivas sobre a realidade física) e jogos de forças em (des)equilíbrio dialético (entre sociedade e natureza) no território e na paisagem é condição sine qua non ao estudo sobre as dinâmicas socioambientais em qualquer parte do planeta, inclusive no município ao qual dedicamos a nossa pesquisa. 
Uma pesquisa sobre dinâmicas e impactos socioambientais, formação histórica do território, peculiaridades da apropriação do território expressas na paisagem. Sim, uma pesquisa sobre estes e não destes elementos em Mirante do Paranapanema. Priorizamos esta forma de abordagem porque também tomamos como meta oferecer uma visão ao mesmo tempo geral e integrada da geografia do município.

Com esta idéia (e intenção) em mente é que incorporamos as categorias de território e paisagem ao desenvolvimento do trabalho: como se um fosse algo semelhante a uma pré-condição para a existência do outro e vice-versa. Determinadas configurações no processo de apropriação/desapropriação/re-apropriação do espaço criam e recriam diversas paisagens: isto se apreende ao considerarmos o município de Mirante do Paranapanema; isto se apreende ao considerarmos a Raia Divisória São Paulo-Paraná-Mato Grosso do Sul.

\section{3) Vinculação ao Projeto Temático "Dinâmicas Socioambientais, Desenvolvimento Local e Sustentabilidade na Raia Divisória SP-PR-MS"}

Deste modo, procuramos entrar em consonância à abordagem definida por Passos (2005) acerca da apreensão da diversidade dos processos que estão envolvidos na caracterização das parcelas territoriais (nos estados de São Paulo, Paraná e Mato Grosso do Sul) que compõem a área por ele denominada Raia Divisória. A abordagem é composta por enfoques em várias dimensões deste território, onde:

[...] é preciso desenvolver estudos dentro do contexto econômico e social
predominante ao longo da história de ocupação [...] e, sobretudo, termos
em consideração as "sucessivas sociedades" e suas relações com o meio,
ou seja, (1) a degradação do meio ambiente a partir de uma análise
integrada: desmatamento-erosão-assoreamento-desperenização dos
cursos d'água; (2) a história do uso e da propriedade da terra; (3) dos
impactos das grandes obras - hidrelétricas, usinas de álcool -; (4) dos
reflexos dos movimentos sociais, notadamente, o MST; (5) dos reflexos
das alteraç̃̃es do potencial ecológico e da exploração biológica sobre a
sustentabilidade do desenvolvimento local-regional. (PASSOS, 2005,
p.11)

Assim, não poderíamos deixar de mencionar a vinculação de nosso estudo aos objetivos de um projeto de pesquisa mais amplo, ou melhor, ao Projeto Temático 
“Dinâmicas Socioambientais, Desenvolvimento Local e Sustentabilidade na Raia Divisória São Paulo-Paraná-Mato Grosso do Sul”, coordenado pelo Prof. Dr. Messias Modesto dos Passos e apoiado pela Fundação de Amparo à Pesquisa do Estado de São Paulo (FAPESP).

Este projeto possui caráter interdisciplinar no que tange à investigação sobre temas voltados ao meio ambiente e desenvolvimento sustentável tanto na escala local (municípios) quanto na escala regional (Raia Divisória). O coordenador do projeto salienta algumas etapas fundamentais ao desenvolvimento das pesquisas que nele estão envolvidas para se chegar à abordagem integrada destas temáticas gerais: estudos sobre o meio ambiente; estudos sobre o desenvolvimento rural e urbano; estudos sobre qualidade e gestão das águas e estudos sobre a dinâmica das áreas de fronteira/raia e sobre a cooperação transfronteiriça. (PASSOS, 2005, p.7)

Algumas hipóteses tomadas como pontos de partida ao desenvolvimento das pesquisas sobre a porção paulista da Raia Divisória, no âmbito do Projeto Temático mencionado, são as seguintes:

- A implantação da Usina Hidrelétrica de Porto Primavera (representada pela CESP) tem introduzido (ou introduziu) uma nova forma de construir a paisagem regional;

A UHE de Porto Primavera foi responsável por criar um ponto de integração na região (polarização), criando novos estímulos para o desenvolvimento regional;

- $\quad$ O Pontal do Paranapanema - Sudoeste do Estado de São Paulo sofreu uma série de mudanças socioambientais desde a chegada da frente pioneira, nos anos 1940. Inicialmente, essa região foi palco do "ciclo do algodão", estruturado a partir do tripé: indústrias beneficiadoras (SANBRA, MACFADEN, CLAYTON, BRASWEY), proprietários de terras e arrendatários. O algodão teve um ciclo curto e, as terras de algodão se transformaram em terras de pastagens. O processo de erosão-lixiviação do solo levou os pecuaristas a adotarem a estratégia de "refazer os pastos"; pouco capitalizados economicamente e culturalmente, os proprietários rurais não investiram 
no sentido de reverter a degradação ambiental e, pior, de reposição das perdas do agrossistema regional;

- A relação com a terra (posse-arrendamento-estrutura fundiária-uso do solo) e a dependência do mundo rural às políticas econômicas "nacionais", cujos agentes locais-regionais não fomentam alternativas para superação das crises, agudizam a degradação ambiental, explicitada de forma didática nas transformações e nas dinâmicas atuais das bacias hidrográficas.

Para a elaboração de nossa pesquisa certamente encontramos no Projeto Temático uma inspiração e nas hipóteses nele apresentadas, um guia para conduzir a abordagem sobre o município de Mirante do Paranapanema, principalmente no que diz respeito à problemática socioambiental expressa na degradação da área rural e conseqüências negativas à população que nela se encontra.

\section{$\operatorname{son}$}

Após apresentarmos mais detalhadamente a temática de pesquisa, faremos uma reflexão teórica sobre o sistema GTP (Geossistema, Território, Paisagem) de Georges Bertrand, referência de maior peso $^{7}$ neste trabalho;

\footnotetext{
${ }^{7}$ Assim o colocamos porque outros autores também são tomados como referenciais, conforme se verificará no decorrer do trabalho.
} 


\section{Capítulo II:}

\section{Referencial teórico-}

metodológico 


\section{soci}

"... o olhar através de um conceito constitui um filtro que ressalta o que esse conceito indica".

(Dirce Maria A. Suertegaray)

8003 
1) Notas introdutórias: o sistema GTP (Geossistema, Território, Paisagem) como novo projeto geográfico para a análise da interface sociedade-natureza

Neste capítulo apresentaremos reflexões a respeito do sistema GTP (Geossistema, Território e Paisagem) desenvolvido pelo geógrafo francês Georges Bertrand. O objetivo deste pesquisador é trazer um método para a Geografia capaz de lidar com a complexidade dos fenômenos entre sociedade e natureza. Além de um método, o referido sistema também pode se prestar como ponto de partida à reflexão epistemológica do "fazer geográfico".

Em um contexto de transformações socioambientais sem precedentes na história, vivenciamos algo semelhante a uma ruptura paradigmática no âmbito das ciências. Estas, por sua vez, são chamadas a tomar novas posturas teórico-metodológicas que possibilitem abordagens integradas e interdisciplinares em seus respectivos ramos de pesquisa, principalmente quando a pauta central é o meio ambiente.

Nossa pesquisa está diretamente voltada à temática do meio ambiente. O que não significa algo novo na Geografia, afinal, consideramos que esta ciência é uma das pioneiras no que tange ao tratamento dos fenômenos entre natureza e sociedade e viceversa, mesmo que os métodos adotados em épocas passadas - hoje bem sabemos - não fossem um tanto quanto eficazes para se analisar a complexidade daquilo que se conhece como espaço geográfico.

Falar de meio ambiente na Geografia pode não ser, talvez, um fato novo. Porém, abordar o meio ambiente por meio de um aporte teórico-metodológico que pretenda lidar com a complexidade dos fenômenos entre natureza e sociedade se torna um desafio inovador para esta ciência e para os pesquisadores envolvidos com a referida temática.

Diante deste desafio, inclinamo-nos à proposta bertrandiana para a compreensão dos fenômenos geográficos e entrada na questão ambiental. Desde seu artigo fundador "Paisagem e Geografia Física Global: Esboço Metodológico", Bertrand (1968) trouxe à tona sua primeira proposta de análise integrada dos sistemas formados pelas interações entre os elementos bióticos, abióticos e antrópicos (geossistemas) para a compreensão dos fenômenos na interface natureza-sociedade. 
Muito embora suas idéias não tivessem grande aceitação no meio científico de seu país de origem (conforme dito pelo próprio pesquisador, em disciplina ministrada no Programa de Pós-Graduação em Geografia da FTC-UNESP, no ano de 2007), o processo de construção e reconstrução epistemológica nunca cessou.

Atualmente, Bertrand $(2002,2007)$ nos traz um sistema tripolar para análise não apenas dos fatos naturais ou sociais isoladamente uns dos outros. A tônica está na interação, na complexidade expressa em variadas formas da relação homem(ens)meio(s).

Este sistema é composto por três categorias híbridas: geossistema ${ }^{8}$, território e paisagem. A teoria geossistêmica se presta para adentrarmos na análise das fontes, dos aspectos geoecológicos de um determinado espaço metamorfoseados em recursos a partir do instante em que sua dinâmica natural é alterada pela utilização humana.

Podemos afirmar que geocomplexos estritamente intactos não existem mais no atual contexto socioeconômico mundial. Não existem porque fazem parte de projetos que buscam atender aos anseios humanos. E onde há projeto humano, há território. Logo, somos automaticamente levados a refletir e analisar todas as implicações da apropriação da natureza também por meio da categoria território.

Onde há território, há representação ou representações sociais que assumem diversas formas e conferem identidade a este território. Como se estivéssemos em meio a um processo semelhante ao de sublimação, passamos a vislumbrar, então, a paisagem: uma categoria indicadora das dinâmicas e das representações territoriais em dado espaço, assim o sistema GTP permite a interpretação mais abrangente da realidade dos

\footnotetext{
${ }^{8}$ Georges Bertrand, em curso ministrado no PPGG/FCT-UNESP (2007), mencionou certa inadequação do uso do termo "geossistema" no âmbito de sua proposta. 0 próprio pesquisador citou uma nomenclatura que seria mais apropriada: o geocomplexo ao invés de geossistema.

No início de sua elaboração teórica, Bertrand concebia o geossistema como uma escala de análise dentro de um conjunto hierárquico compreendido por seis níveis temporo-espaciais decrescentes: zona, domínio, região natural, geossistema, geofácies e geótopos. Mas na verdade seria o geocomplexo a primeira escala de análise (entre as seis) que se presta ao estudo dos impactos humanos.

"Geo+complexo" por englobar as geofácies e geótopos bem como as relações estabelecidas entre elementos bióticos, abióticos e antrópicos. 0 geocomplexo é a escala de análise geográfica. 0 geossistema é a teoria que guia a abordagem desta escala.

Deste ponto em diante de nosso texto, utilizaremos o termo geocomplexo caso nos referirmos a esta escala de análise. Enquanto falarmos de teoria geossistêmica, o termo geossistema será mantido.
} 
fenômenos geográficos. Através deste sistema é possível alcançar análises diferenciadas e complementares, concomitantemente.

Desta forma, optamos pela análise sobre as dinâmicas socioambientais expressas na paisagem de Mirante do Paranapanema tendo como guia teórico-metodológico o sistema GTP (Geossitema-Território-Paisagem).

A partir destas notas introdutórias, iremos discorrer mais detalhadamente sobre os principais aspectos da trajetória histórico-científica deste sistema, conduzida por Georges Bertrand.

Em um primeiro momento iremos tratar da maneira pela qual a Geografia se posiciona perante a relação sociedade-natureza. Posteriormente, faremos uma passagem aos fins dos anos 1960 para expor o momento da elaboração da teoria geossistêmica (para análise da paisagem). Por fim, chegamos às reflexões sobre a tríade GTP e sua relevância à análise geográfica do meio ambiente.

Esta é a linha mestra deste capítulo.

\section{2) Um sentido para a Geografia na análise da relação sociedade-natureza}

É possível dizer que toda sociedade/toda cultura cria, inventa, institui uma determinada idéia do que seja a natureza. Neste sentido, o conceito de natureza não é natural, sendo na verdade criado e instituído pelos homens. Constitui um dos pilares através do quais os homens erguem as suas relações sociais, sua produção material e espiritual, enfim, a sua própria cultura. (GONÇALVES, 1998)

Assim, a natureza totalmente (direta ou indiretamente) antropizada não é mais o que ela era no passado remoto e os desafios impostos com a emergência da questão ambiental no planeta devem ser encarados como marcos de "um retorno da natureza e do natural que a expansão econômica aparentemente ilimitada tinha apagado com a artificialização crescente do mundo" (BERTRAND, 2007, p.197)

O desenvolvimento tecnológico - e suas repercussões na economia mundial durante o século XX - levaram ao esmaecimento da natureza em um cenário no qual era a artificialização o fato preponderante. 
Bertrand nos lembra que a natureza não é mais do que um ponto de partida do qual se afasta cada vez mais a sociedade humana em marcha (2007, p.63). E, podemos acrescentar que o próprio conhecimento científico avalizou este aparente desligamento do homem de suas raízes naturais. Atualmente, a marcha científica não pode mais se manter silenciosa sobre esta realidade.

Os valores e a significação dos acontecimentos naturais estão alterados pela sociedade ao mesmo tempo em que alteram a própria sociedade. A perplexidade paradigmática inquieta a razão de ser dos pesquisadores engajados no aprofundamento de seus conhecimentos acerca da relação sociedade-natureza (ou natureza-sociedade), sobretudo quando se trata de elaborar projetos para fins de utilidade pública: contribuições para o desenvolvimento - socioeconômico, socioambiental - de um determinado território.

\footnotetext{
Ora, a relação maniqueísta clássica natureza-cultura, naturezasociedade, natureza-homem (são relações diferentes, mas elas são freqüentemente confundidas) permeiam ainda mais ou menos implicitamente as práticas científicas mais quotidianas. $\mathbf{O}$ postulado materialista que o homem, e então a sociedade, está na natureza e não fora dela, e muito menos "contra" ela, assume toda sua amplitude e pode se tornar a pedra angular de uma reflexão renovada sobre o lugar e o papel da geografia física e dos geógrafos no desenvolvimento atual da pesquisa naturalista e social. (BERTRAND, 2007, p.63, grifo nosso)
}

Um “retorno à natureza" (BERTRAND, 2007, p.63) é imprescindível. A Geografia se destaca por sua tradição de trabalho flutuante entre os fatos naturais e os sociais. "Os geógrafos são os intercessores entre certo conhecimento naturalista e certas formas de análise social". (BERTRAND, 2007, p.63) Porém, os empréstimos conceituais de outras ciências e os discursos aproximativos foram incapazes de definir e tratar até mesmo do objeto ao qual a Geografia se dedicou em um contexto onde o "conhecimento da natureza foi dividido em subáreas do conhecimento" (SUERTEGARAY, 2002, p.112), sob uma complicada compartimentação que levou (ainda leva?) a uma espécie de esmaecimento desta disciplina diante de si própria, bem como perante outras... 


\title{
3) A Geografia esmaecida pela ecologia
}

Atualmente,

\begin{abstract}
Alguns recursos essenciais se degradam ou se esgotam; os grandes ciclos naturais estão ou parecem perturbados; as paisagens familiares desaparecem para sempre. A natureza natural não é mais um dado certo. Está emergindo uma outra natureza, forte, mas finita; um universo natural, coberto de crises, de catástrofes e de irreversibilidades; um conjunto frágil que apreendemos com um olhar novo, cheio de admiração e de temor, e um pensamento novo, original e audacioso. A ecologia acaba de reinventar a natureza e de redesenhar uma economia política do planeta. (BERTRAND, 2007, p.83, grifo nosso)
\end{abstract}

Durante fins da década de 1960, a Ecologia apresentava corpo teórico e metodológico tão bem articulado que foi capaz de fazer algo ainda não realizado pela Geografia (sobretudo a Geografia Física) naquele momento: desbloquear o conhecimento naturalista de métodos "introspectivos". O conjunto metodológico, no domínio da Ecologia, organizou-se da seguinte forma: níveis de integração dos "objetos" biológicos da célula até a biosfera, ciclos dos elementos, situação do metabolismo dos seres vivos, reconstituição das cadeias tróficas, cálculo dos fluxos energéticos e das diferentes formas de produtividade etc.

Neste contexto, a pesquisa naturalista clássica perdeu espaço para as novas proposições da emergente ecologia de síntese, sendo o ecossistema uma potente "ferramenta" (teórico-metodológica) de trabalho. O ecossistema emergiu como um conceito sem a pretensão de substituir ou mesmo de solapar os procedimentos setoriais mais clássicos. Na realidade se tratou muito mais de uma evolução no âmbito das ciências naturais ao passo que a complementaridade das estratégias da pesquisa foi de fundamental importância para a nova acepção metodológica: o estudo das partes era pertinente e deveria ser posicionado em uma estrutura inter-relacional que permitisse a abordagem coesa de um dado objeto.

Mas,

O ecossistema resolveu a análise integrada da biosfera ao mesmo tempo nos planos teórico e prático. $\mathrm{Na}$ entrada do sistema, estão as plantas verdes e a fotossíntese que, pela assimilação clorofiliana, determinam o funcionamento complexo e hierarquizado do encadeamento trófico. $\mathrm{O}$ circuito da matéria é estabelecido e 
cientificamente dominado. Este esquema explicativo foi constituído por biólogos e para uma finalidade biológica. É bem verdade que ele integra e contabiliza em seu funcionamento elementos não vivos. Mas estes são naturalmente rejeitados para a periferia do sistema. Eles estão então subordinados, simplificados, às vezes mutilados e até esquecidos. É o caso, por exemplo, do conjunto dos processos geomorfogênicos que, no entanto, interferem com os seres vivos, mas em níveis temporais e espaciais ainda pouco conhecido dos ecólogos. $\mathbf{O}$ ecossistema é uma abordagem ecológica da natureza, ele não é toda a natureza, e não devemos desviá-lo do seu objetivo biológico. (BERTRAND, 2007, p.72, grifo nosso)

A crítica ao modelo ecossistêmico foi posta. Então, nos questionamos: e o (s) objetivo (s) da abordagem geográfica quais seriam, ou quais deveriam ser perante a emergência de novos métodos de análise da natureza, da relação entre a sociedade e a natureza, enfim, do meio ambiente?

Conforme anteriormente exposto, temos certa idéia do papel decisivo da Ecologia de síntese, sua evolução e inovações que dizem respeito ao modo sistêmico de apreensão da dinâmica natural. Por outro lado, não podemos perder de vista o fato do ecossistema, apesar de todas as suas potencialidades, também apresentar seus pontos fracos: escala bastante "volúvel", localização relativamente complicada, marginalização dos processos abióticos e abordagem equivocada da dinâmica social.

Diante disto, o geógrafo também deve se manter insatisfeito com o método ecológico. A pesquisa ecológica é equívoca em sua essência por se tratar "[...] de nada menos do que a emanação científica do biologismo" (BERTRAND, 2007, p.84), onde:

A maior parte da biologia [...] tem uma visão mecanicista da vida e tenta reduzir o funcionamento dos organismos vivos a mecanismos celulares e moleculares bem definidos. A concepção mecanicista é justificada, em certa medida, pelo fato de os organismos vivos agirem, em parte, como máquinas. Eles desenvolvem uma grande variedade de peças e mecanismos semelhantes a máquinas - ossos, músculos, circulação sangüínea, etc. -, provavelmente porque o funcionamento mecânico era vantajoso para sua evolução. Isso não significa, porém, que os organismos vivos sejam máquinas. Os mecanismos biológicos são apenas exemplos especiais de princípios muito mais amplos de organização; de fato, nenhuma operação de qualquer organismo consiste inteiramente em tais mecanismos. (CAPRA, 2001, p.260, grifo nosso)

Esta passagem de Capra elucida, fortuitamente, a crítica bertrandiana sobre os fundamentos da Ecologia fortemente conectados aos esquemas da biologia mecanicista. 
Não são apenas estes esquemas que dominam a organização da vida. Uma sociedade humana é composta por indivíduos de estrutura biológica, mas, com comportamentos (guiados por pensamentos) específicos que os diferencia definitivamente de outros seres vivos.

A Ecologia se prestou como uma ciência balizadora da globalização e conceitualização, sistematização e modelização, diferenciação e diversificação, enfim, de uma aproximação entre as "abundantes e heteróclitas pesquisas naturalistas" (BERTRAND, 2007, p.83). Porém, “[...] entre a ecologia científica e as ciências sociais subsiste um hiato" (p. 77).

É nesta abertura, neste hiato, que a Geografia deve se posicionar. Mas, não sob a égide de métodos inconsistentes e até mesmo ultrapassados. Afinal, isso significaria uma retroalimentação do "vício" da dicotomização tradicionalmente herdada e nãooperacional. Um novo procedimento é imprescindível diante da nova visão da realidade.

A nova visão da realidade [...] baseia-se na consciência do estado de inter-relação e interdependência essencial de todos os fenômenos físicos, biológicos, psicológicos, sociais e culturais. Essa visão transcende as atuais fronteiras disciplinares e conceituais e será explorada no âmbito de novas instituições. Não existe, no presente momento, uma estrutura bem estabelecida, conceitual ou institucional, que acomode a formulação do novo paradigma, mas as linhas mestras de tal estrutura já estão sendo formuladas por muitos indivíduos, comunidades e organizações que estão desenvolvendo novas formas de pensamentos que se estabelecem de acordo com novos princípios. (CAPRA, 2001, p.259, grifo nosso)

A tarefa da Geografia neste contexto é trazer para si um paradigma da natureza, considerada, sim, como um mega conjunto de formas, processos físico-químicos e biológicos que promovem seu movimento, afinal os elementos naturais possuem dinâmica própria, não dependendo de nenhuma apropriação social para que existam e:

[...] como tal desempenham papel fundamental na estruturação do espaço geográfico. Mesmo integrantes de espaços apropriados pelo homem e sua sociedade, não escapam ao controle do fluxo de matéria e energia que rege a existência do sistema solar, do planeta Terra e seus componentes. É bem verdade que em muitos lugares - como as grandes cidades e seu cotidiano, por exemplo -, tem-se a falsa impressão de que o homem é o grande regente, que a "natureza" e suas forças ou não 
existem ou foram subjugadas aos desígnios humanos. (MENDONÇA, 2002, p. 138-139, grifo nosso)

Realmente uma falsa impressão, visto que a sociedade não tem pleno controle sobre a dinâmica da natureza embora esta esteja bastante alterada pela ação antrópica. Neste sentido, nos inclinamos à idéia de um projeto geográfico não restrito apenas à análise do fato natural em si, pois, a dimensão geográfica da natureza é dada a partir do momento em que ela é encarada no viés da sociedade, ou seja, em termos de espaço social, produzido pelo trabalho humano, por valores e representações.

\section{4) Um novo projeto geográfico}

É possível dizer que a ciência moderna desumanizou a natureza e desnaturou o ser humano ao passo que se configurou em torno de três eixos principais: a oposição homem e natureza; a oposição sujeito e objeto e o paradigma atomístico-individualista. (Cf. GONÇALVES, 1998).

Tais eixos levaram a uma divisão cada vez mais incisiva entre as ciências da sociedade e as ciências da natureza, bem como uma infinidade de setorizações/dicotomizações no seio das próprias disciplinas em si. Houve também outro problema: muitas vezes a sociedade foi analisada por métodos pertencentes às ciências da natureza e estas, por sua vez, mergulharam tanto dentro de si a ponto de uma quase cegueira, surdez e insensibilidade diante da dinâmica/interação/integração dos próprios fatos naturais.

Porém,

Independentemente desta prática, alguns geógrafos buscaram construir um conhecimento mais conjuntivo. [...] $O$ método sistêmico proveniente da biologia dos anos 20 foi adotado na geografia com o objetivo de promover uma análise integrada da natureza. [...] Ao buscar este caminho construíram-se conceitos como o de geossistema, que, por sua vez, ultrapassa na sua construção a integração do conhecimento da natureza. Ultrapassa, porque inclui o homem (ação do homem) neste contexto. Esta concepção, ainda que naturalize a ação do homem, impõe uma outra discussão que, em nosso entendimento, ultrapassa a geografia física. Ultrapassa, na medida em que resgata para a análise a dimensão antrópica, característica central da geografia enquanto ciência da relação natureza e sociedade. (SUERTEGARAY, 2002, p.113) 
Nesta perspectiva, Bertrand (2007) nos lembra de um exercício que geralmente não praticamos: a necessidade de se objetivar a natureza em nome da compreensão de sua estrutura e seu funcionamento. E somente isso não basta. É preciso ir além e fazer a natureza passar através do filtro dos valores e das representações, afinal um não ocorre sem o outro.

Por muito tempo perdida ou compartimentada, a natureza, isto é, o universo físico considerado globalmente como sistema, é reencontrada e interrogada. Uma nova "dialética da natureza" está em gestação. Ela já revolucionou o campo próprio das ciências da natureza, primeiramente pelo canal das ciências ditas exatas, em seguida, por aquele das disciplinas bioquímicas e, mais recentemente, ecológicas. Esta onda epistemológica e metodológica, que é bem preciso ser qualificada de naturalista, começa a penetrar as ciências da sociedade até aqui bastante estranhas aos fatos naturais e geralmente pouco preocupadas em levá-los em consideração. Esta situação não é nova. Ela reata com a tradição naturalista dos três séculos precedentes ao longo dos quais a natureza e o natural, sob formas tão diferentes e contraditórias quanto o darwinismo, o organicismo, o romantismo, o positivismo, etc., ocuparam um lugar privilegiado - freqüentemente o primeiro - no movimento filosófico e cientifico do mundo ocidental. (BERTRAND, 2007, p.62, grifo nosso)

Neste sentido, salientamos um primeiro esboço metodológico que surgiu em nome de algo posteriormente conhecido como Geografia Física Global. Fortemente influenciado por princípios da escola naturalista soviética, o geógrafo francês Georges Bertrand $(1968,1973,1978)$ expôs sua preocupação com a adoção de uma abordagem integrada da natureza tendo como ponto de partida o estudo da paisagem.

Assim, destacamos alguns aspectos da escola soviética que, sobretudo a partir de meados do século XX, apresentou uma disciplina metodológica nas pesquisas baseada nos estudos de Complexo Natural Territorial ${ }^{9}$ (ou de geossistemas), influenciando com significativo peso a produção científica de Georges Bertrand.

Embora muito restrita ao campo da Geografia Física no tratamento da natureza, a escola naturalista soviética fez com que seus discípulos apreendessem, desde então, a

\footnotetext{
${ }^{9}$ Com o lançamento do termo geossistema por V. B. SOCHAVA, concebido como a combinação do Complexo Natural Territorial - de DOKOUTCHAEV - com a ação antrópica, a ciência da paisagem ganha maior corpo teórico na ex-União Soviética durante a década de 1960, sendo que tais idéias logo iriam se disseminar para os outros países, tanto da Europa quanto da América. (Cf. PASSOS, 1988, 2000)
} 
"ambivalência" da paisagem e utilizassem diversos métodos de abordagem paisagística na organização do espaço.

A partir da influência da escola soviética, podemos identificar três grandes métodos de análise da paisagem. O primeiro deles referia-se à análise físico-geográfica da Landschaftovedenie. Desenvolvida nos diversos ramos da Ciência da Paisagem na exURSS e apoiada sobre a coleta ou utilização de informações concernentes ao meio natural; com a prática de prospecções de grandes territórios ou observações estacionais sistemáticas sobre os mesmos.

Os geógrafos soviéticos, no começo mais ou menos inspirados pela
ciência natural da Europa Central (Landschaft), mas, sobretudo
encorajados pela política de reconhecimento e de valorização das terras
virgens, foram levados a construir um método de pesquisa que lhes
permitisse apreender rapidamente novos territórios na sua
integralidade. [...], as diversas tentativas de análise integrada do
complexo físico-geográfico deram origem a uma potente ferramenta
teórica e metodológica que põe em jogo meios técnicos sofisticados. Esta
"ciência do geossistema" [...] repousa totalmente sobre a medida dos
balanços geoquímicos e dos fluxos energéticos globais. Existem
numerosas fases intermediárias em que ocorrem estudos qualitativos e
quantitativos, estacionais ou "expedicionais" (survey), estruturais
(geohorizontes) ou evolutivas (etologia dos geossistemas). (BERTRAND,
2007, p.73, grifo nosso)

Portanto, os procedimentos detiveram-se nos estudos, no espaço e no tempo, das diferenciações dos elementos constitutivos de complexos geossistêmicos. Em um primeiro momento a abordagem da paisagem, nesta perspectiva, foi material e objetiva e as principais informações recolhidas e tratadas foram exclusivamente físicas e bióticas para fins de modelizações. Posteriormente, o interesse poderia se estender ao sujeito, incluindo o homem e suas atividades. Vale ressaltar que nesta abordagem metodológica, a análise do meio foi o ponto de partida. A noção de Complexo Natural Territorial foi fundamentada nesta abordagem, futuramente contribuindo para a formação do conceito de geossistema.

Mais precisamente [...], este complexo (CNT) constitui a parte do meio ambiente que é totalmente estranha ao homem: combinado com os impactos da utilização antrópica, ele forma um geossistema, o qual, percebido e interiorizado pelo homem, determinará uma paisagem. (PASSOS, 1995, p.16, grifo nosso) 
Conforme exposto anteriormente, as informações colhidas e tratadas eram exclusivamente físicas e bióticas, daí a decomposição do Complexo Natural Territorial em duas subunidades:

i) geoma: unidade físico-química;

ii) biocenose: unidade biótica;

E as análises eram efetivadas sobre uma ou outra unidade.

O segundo método se referia à análise paisagística naturalista que, também, reduziu o campo da pesquisa ao nível material, apresentando resultados fragmentários ou incompletos, centrando-se apenas no exame da composição vegetal e suas relações com os dados mesológicos como ocorreu com as pesquisas do Centre d'Études Phytossociologiques et Écologiques du CNRS10 (CEPE/Montpellier), na França. Esta abordagem também se apoiou na sobreposição entre cartas que traduziam o meio natural com aquelas que exprimiam a utilização do solo, principalmente durante os anos de 1970, devido às preocupações novas advindas da organização racional do espaço.

\section{Conforme Passos,}

Os métodos da paisagem-objeto se distribuem entre três grandes tipos. Cada um dos dois primeiros se situa num dos "pólos" da relação da paisagem, objeto ou sujeito, um de ordem cognitiva, outro de ordem afetiva. A estas duas categorias muito comumente reconhecidas, parece necessário acrescentar uma terceira que, mais que intermediária entre elas, se apresenta como integradora, usando de técnicas emprestadas, às vezes, a uma e a outra. (1995, p.16, grifo nosso)

Nesta categoria integradora, encaixaram-se os métodos da paisagem percebida (ainda com grande influência dos estudos da escola soviética). A partir do qual Georges Bertrand, enquanto expoente da Escola de Toulouse, na França, passou a realizar tratamentos sistemáticos da informação em matéria de paisagens. Tendo como grande preocupação passar da monografia ao modelo e praticar o estudo da paisagem como uma análise integrada de sistema.

\footnotetext{
${ }^{10}$ Centro de Estudos Fitossociológicos e Ecológicos do Centro Nacional da Pesquisa Científica - Montpellier.
} 
A paisagem, neste sentido, passou a ser tratada como um conceito interdisciplinar/diagonal cuja apreensão deveria ocorrer de maneira global, inclusive levando-se em consideração a sua dimensão socioeconômica. Portanto, é válido destacar que tal apreensão não pôde resultar de tentativas parciais: ela esteve sustentada no seguinte princípio: o desdobramento e a análise separada dos elementos constitutivos e das diferentes características espaciais, psicológicas, econômicas, ecológicas etc. não permitem dominar o conjunto.

Os métodos da paisagem percebida (na perspectiva geossistêmica bertrandiana) consistiram em "ir da Sociedade para a Natureza", diferentemente da premissa metodológica da análise físico-geográfica da Landschaftovedenie ${ }^{11}$. A importância que as ações da sociedade ganharam no contexto destes métodos deveu-se ao entendimento de que um espaço e uma estrutura geológica não se tornam paisagem senão a partir de um mecanismo social de identificação e de utilização.

Assim, a noção de sistema passou a permitir o enfoque na paisagem como um polissistema formado pela combinação dos sistemas natural, social, econômico e cultural onde há integração horizontal entre todos eles, possibilitando a análise do conjunto dos elementos sociais e ecológicos combinados sobre um mesmo espaço.

Desta forma, podemos dizer que o conceito de geossistema automaticamente nos remete à abordagem geográfica do fato natural associada ao enfoque no jogo de relações imbricadas e, assim, consubstanciadas na própria essência da natureza, inclusive de uma natureza apropriada pela sociedade. Apropriação geradora de

\footnotetext{
11 A este respeito é importante salientarmos que a escola soviética também considerava os fatores econômicos e sociais que influenciam a estrutura da paisagem (analisada na perspectiva geossistêmica). Porém, à síntese da paisagem nem sempre caberiam os fatores socioeconômicos integralmente. É interessante uma passagem de Rodrigues (2001) sobre este assunto: "Uma colocação básica a respeito dos geossistemas é feita por SOTCHAVA (1977) [...]. Chama atenção para o fato de que os geossistemas, embora sejam considerados "fenômenos naturais", devem ser estudados à luz dos fatores econômicos e sociais que influenciam sua estrutura. Os geossistemas podem refletir parâmetros sociais e econômicos que influenciam importantes conexões em seu interior. Essas influências antropogênicas podem representar o estado diverso do geossistema em relação ao seu estado original. Este estado derivado muitas vezes pode ser mantido por meio de outras intervenções técnicas, também passíveis de reconhecimento. Acrescente que, apesar dos fatores sócio-econômicos modificarem um geossistema, 'a noção sobre este último não pode abranger a do sistema territorial - industrial' (SOTCHAVA, 1977), o que não exclui a possibilidade ou a existência de 'sistemas totais que representem sistemas geográficos, econômicos, sociais e técnicos' (SOTCHAVA, 1977). Essas afirmações explicitam o nível de síntese, no qual se pretendia trabalhar através da consideração dessa teoria e parecem revelar que, para o autor, a Geografia não caberia integralmente na abordagem". (RODRIGUES 2001, p.73)
} 
impactos manifestos no espaço, direta ou indiretamente perceptíveis na (s) paisagem (ens).

\section{5) Paisagem e geossistema}

...impactos manifestos no espaço, direta ou indiretamente perceptíveis na (s) paisagem (ens). Portanto, a paisagem em si passou a ser vista como expressão da complexidade dos fenômenos geográficos. Uma "explosão" entre a aparência e a essência. Materialidade e imaterialidade. Objetiva. Subjetiva. Diretamente relacionada à percepção em qualquer um dos seus níveis: mediato ou imediato.

Então, nos dias atuais, podemos afirmar que a paisagem sempre foi uma porta de entrada para as análises geográficas. Mesmo de modo indireto, porém, nunca passando despercebida: se nos dedicamos a pesquisar um determinado objeto é porque de alguma forma ele nos desafia, incomoda, questiona e nos gera o desejo em tentar decifrar os "enigmas" possivelmente mascarados por alguns "estigmas" que a nossa percepção mais imediata pode conferir a este objeto.

Um fenômeno se materializa no espaço. Produz uma paisagem ao passo que também lhe confere vida/dinamismo neste processo de manifestação/materialização espacial. A partir do instante em que o fenômeno se torna objeto de nossa percepção, somos despertos pela curiosidade e tentativas de compreensão.

Por este motivo, independentemente da (s) categoria (s) de análise utilizada (s) para a elaboração de um determinado estudo geográfico, a paisagem sempre aparecerá, implícita ou explicitamente, mesmo que este não seja o objetivo principal do pesquisador.

Talvez por estes atributos, a paisagem se apresente plena de imprecisões como noção vaga e (in)cômoda "que cada um utiliza a seu bel prazer" (BERTRAND, 2007, p.7). Ora simplesmente ignorada, ora restrita por infinitos qualificativos que alteram seu significado.

Para Bertrand, este fato reflete um problema de ordem epistemológica, onde: 
[...] o conceito de "paisagem" ficou quase estranho à geografia física moderna e não tem suscitado nenhum estudo adequado. [...] tal tentativa implica numa reflexão metodológica e pesquisas específicas que escapam parcialmente a geografia física tradicional. Esta é, com efeito, desequilibrada pela hipertrofia da pesquisa geomorfológica e por graves carências, em particular no domínio das ciências biogeográficas. Enfim, ela permanece essencialmente analítica "separativa", enquanto que o estudo das paisagens não pode ser realizado senão no quadro de uma geografia física global. (BERTRAND, 2007, p.7, grifo do autor)

Então, este autor passou a fundamentar suas pesquisas no conceito de geossistema. Trabalhou com este conceito, no âmbito da Geografia física, porque procurava (em fins da década de 1960) abordar a paisagem de modo integrado e global. A sua proposta metodológica tinha como finalidade sair da monografia e chegar ao modelo, em termos de estudos da paisagem, ao mesmo tempo em que criticava a abordagem setorizada da natureza na ciência geográfica.

\section{1) O geossistema}

... ao mesmo tempo em que criticava a abordagem setorizada da natureza na ciência geográfica. Então, é possível afirmar que o geossistema surgiu na Geografia não apenas como conceito ou modelo teórico da paisagem. Muito além de "ferramenta" de trabalho, ele foi posto diante dos olhos dos geógrafos (sobretudo após a década de 1970 com Georges Bertrand) como primeira expressão da insatisfação quanto aos métodos pautados por uma complicada fragmentação e setorização da realidade geográfica e das análises que deveriam tratar desta mesma realidade, respectivamente.

Deste modo, Bertrand (1968) propôs uma classificação de acordo com seis níveis temporo-espaciais ${ }^{12}$ decrescentes: zona, domínio, região, geossistema13, geofácies e

\footnotetext{
12 Sobre esta classificação, Rodrigues (2001, p.73-74) nos lembra que: "Para o sistema taxonômico, BERTRAND (1972) [...] define que a classificação deva ser proposta em função da escala temporo-espacial. Haveria unidades superiores, compatíveis com as 'zonas', 'domínios', ou 'regiões naturais' e unidades progressivamente inferiores, que definiriam os 'geossistemas', 'geofácies' e 'geótopos'. Essa colocação apesar de referir-se à classificação e não a identificação dos geossistemas propriamente dita, faz parte do processo de reconhecimento, já que auxilia no dimensionamento temporo-espacial das unidades espaciais, as quais também se articulam.

BERTRAND (1972) reafirma a importância da identificação dos geossistemas, por se situarem na $4^{\underline{a}} 5^{\underline{a}}$ ou $6^{\underline{a}}$ grandezas temporo-espaciais de TRICART \& CAILLEUX (1956), escala esta mais compatível com a humana, em que a dinâmica desses geossistemas, modificado ou não, poderia expressar a dinâmica social. (grifo da autora)
} 
geótopo. Esta classificação foi inspirada pelas escalas temporo-espaciais de caráter geomorfológico de A. Cailleux, J. Tricart e G. Viers; de caráter climático de M. Sorre e nas correspondências aproximativas com a classificação de unidades trabalhadas pelo homem de R. Brunet. (ver quadro 1, p.47)

Conforme Bertrand:

Foi necessário montar todas as peças das unidades globais inferiores à região natural. Após numerosos ensaios, forjaram-se 3 entidades novas: o geossistema, o geofácies e o geótopo. Estes termos têm a vantagem de não terem sido utilizados, de serem construídos num modelo idêntico e de evocar cada um o traço característico da unidade correspondente. $\mathrm{Na}$ verdade geo "sistema" acentua o complexo geográfico e a dinâmica de conjunto; geo "fácies" insiste no aspecto fisionômico e geo "topo" situa essa unidade no último nível da escala espacial. (BERTRAND, 2007, p.15, grifo nosso)

Fica evidente a influência da abordagem naturalista soviética sobre as idéias do referido autor, porém, ele vai além em suas proposições, inserindo - de fato - a preocupação com a ação antrópica na estruturação de um geocomplexo. É possível dizer que suas pesquisas detiveram-se às escalas inferiores, por considerá-las como objeto direto do impacto das sociedades sobre o meio natural, onde "se situa a maior parte dos fenômenos de interferência entre os elementos da paisagem e que evoluem as combinações dialéticas mais interessantes para o geógrafo". (BERTRAND, 2007, p.18)

\footnotetext{
13 Aqui mantivemos a nomenclatura original (sem substituir geossistema por geocomplexo) porque estamos tratando da elaboração teórica do autor em um contexto específico.
} 


\begin{tabular}{|c|c|c|c|c|c|c|}
\hline \multirow[b]{2}{*}{$\begin{array}{l}\text { Unidades da } \\
\text { paisagem }\end{array}$} & \multirow{2}{*}{$\begin{array}{c}\text { Escala } \\
\text { temporo- } \\
\text { espacial } \\
\text { (G }= \\
\text { grandeza) }\end{array}$} & \multicolumn{5}{|c|}{ Unidades elementares } \\
\hline & & Relevo (1) & Clima (2) & Botânica & Biogeografia & $\begin{array}{c}\text { Unidade } \\
\text { trabalhada } \\
\text { pelo homem } \\
\text { (3) }\end{array}$ \\
\hline ZONA & G.I & & Zonal & & Bioma & Zona \\
\hline DOMÍNIO & G. II & $\begin{array}{l}\text { Domínio } \\
\text { estrutural }\end{array}$ & Regional & & & $\begin{array}{l}\text { Domínio } \\
\text { Região }\end{array}$ \\
\hline $\begin{array}{l}\text { REGIÃO } \\
\text { NATURAL }\end{array}$ & G. III - IV & $\begin{array}{l}\text { Região } \\
\text { natural }\end{array}$ & & $\begin{array}{l}\text { Andar } \\
\text { Série }\end{array}$ & & $\begin{array}{c}\text { Quarteirão } \\
\text { rural ou } \\
\text { urbano }\end{array}$ \\
\hline GEOSSISTEMA & G. IV - V & $\begin{array}{l}\text { Unidade } \\
\text { estrutural }\end{array}$ & Local & & $\begin{array}{c}\text { Zona } \\
\text { equipotencial }\end{array}$ & \\
\hline GEOFÁCIES & G. VI & & & $\begin{array}{c}\text { Estádio } \\
\text { Agrupamento }\end{array}$ & & $\begin{array}{c}\text { Exploração } \\
\text { ou } \\
\text { quarteirão } \\
\text { parcelado } \\
\text { (pequena } \\
\text { ilha ou } \\
\text { cidade) }\end{array}$ \\
\hline GEÓTOPO & G. VII & & Microclima & & $\begin{array}{l}\text { Biótopo } \\
\text { Biocenose }\end{array}$ & $\begin{array}{c}\text { Parcela } \\
\text { (casa em } \\
\text { cidade) }\end{array}$ \\
\hline
\end{tabular}

Quadro 1: Classificação escalar da análise geográfica conforme a proposta geossistêmica de Bertrand (1968). As correspondências entre as unidades são muito aproximativas e dadas somente a título de exemplo. (1) Conforme A. Cailleux - J. Tricart e G. Viers; (2) Conforme M. Sorre; (3) Conforme R. Brunet. Fonte: BERTRAND, 2007, p.16. Adaptações: Reginaldo J. Souza

\section{Para Passos,}

Na proposta de BERTRAND (1968), a paisagem é considerada "como uma entidade global; admite-se implicitamente que os elementos que a constituem participam de uma dinâmica comum, que não corresponde, obrigatoriamente, à evolução de cada um dentre eles tomados separadamente". A própria ação antrópica é considerada como um elemento essencial, para a compreensão do geossistema e sua dinâmica. (PASSOS, 1995, p.21, grifo nosso)

Por este prisma, a paisagem, aos poucos, foi tomando caráter interdisciplinar. Um conceito diagonal ampliado ao conjunto das ciências humanas, adquirindo novas dimensões e significados. Mas, esta polifonia ainda não contribuiu para uma definição mais precisa do seu conteúdo e, tampouco, possibilitou a resolução dos problemas de ordem metodológica para a sua análise. 
Muito além de uma retomada dos princípios teóricos bertrandianos, trouxemos à luz desta exposição rápidas considerações sobre a paisagem e a teoria geossistêmica porque nos levam a repensar o tratamento da natureza no âmbito da Geografia. O debate geográfico acerca da paisagem, em sua origem, esteve profundamente vinculado à própria abordagem da dinâmica da natureza e - atualmente, mais do que nunca - à maneira pela qual a sociedade com ela se relaciona.

Relação plena de toda a velha e conhecida exploração predatória de tempos passados. Como se fosse uma espécie de rugosidade persistente em um meio técnicocientífico-informacional desenvolvido pela criatividade humana. Esta capaz de fazer o homem voar, comprar, pisar na Lua, lançar robôs em outros planetas, elaborar potentes aceleradores de partículas, mas ainda deixando a desejar no que diz respeito à busca por uma nova racionalidade norteadora da relação sociedade-natureza.

\section{6) Um novo projeto geográfico: o sistema GTP (Geossistema, Território, Paisagem)}

...no que diz respeito à busca por uma nova racionalidade norteadora da relação sociedade-natureza.

Falarmos de uma nova racionalidade capaz de mobilizar toda a humanidade à procura por soluções aos problemas socioambientais está no plano da utopia, ao menos por enquanto, devido a inúmeros motivos. Tão inúmeros quanto às tantas inviáveis dicotomias e "mudas polifonias", ao mesmo tempo produtos e processos de uma ciência setorizada - potente instrumento formador de opiniões.

Por outro lado, também é preciso dizer que não estamos aqui para cantar a falência desta mesma ciência ou criticá-la pura e simplesmente por suas teorias e métodos adotados no passado, mas que de um modo ou outro foram pensados/elaborados em acordo com as possibilidades e demandas existentes em contextos históricos diferentes do atual.

Outras posturas epistemológicas e teórico-metodológicas surgem em um quadro de mudanças paradigmáticas... 
Anteriormente, expusemos alguns aspectos da relação sociedade-natureza e a forma como foi abordada pela ciência de um modo geral e mais especificamente pela Geografia. Tratamos da relevância da paisagem como ponto de partida para a análise geográfica e da teoria geossistêmica enquanto importante salto qualitativo para a compreensão da natureza vinculada à trama de valores e representações dos homens, ou seja, fora da compartimentação científica que mais dificulta a análise do que dedica atenção à complexidade inerente à realidade dos fenômenos geográficos.

Tomamos como base alguns autores para a elaboração deste capítulo (conforme é possível perceber ao longo das reflexões aqui expostas), mas em todos os momentos não deixamos de acompanhar as reflexões de um autor específico. Isso não foi/não é por acaso. Nosso foco está direcionado ao pensamento de Georges Bertrand por considerarmos suas idéias e produção científica de extrema relevância não apenas à elaboração de nosso trabalho, mas à própria epistemologia da Geografia e/ou do meio ambiente na Geografia.

A partir de fins da década de 1960, o geógrafo introduziu o método sistêmico em suas pesquisas para estudar a paisagem não apenas sob um único ponto de vista: natural ou social. Seu objetivo foi apreender a relação homem-meio na ótica da paisagem produzida na interface entre a natureza e a sociedade. E por que foi preciso tomar a paisagem como produto de interface?

O momento em que Bertrand expunha sua abordagem era, notadamente, de forte aceitação do modelo ecossistêmico no âmbito de diversos ramos científicos, inclusive, na Geografia.

O ecossistema realmente foi um exemplo metodológico seguido por um conjunto de ciências. Porém, a Ecologia aparecia como uma ciência biocêntrica e o ecossistema, neste contexto, teve seu foco no balanço energético e sua relação com a produção de matéria viva pelo mecanismo da fotossíntese, do metabolismo e da cadeia alimentar. Os elementos abióticos, de certa forma, subordinados aos processos e elementos vivos fazendo prevalecer o vegetal e animal como centros reativos da paisagem e a sociedade humana sendo vista por meio de conceitos biologizantes e: 
A transmissão da ecologia para o ensino e a sociedade em geral realizouse em grande parte através do modelo simplificador e integrador do ecossistema... ou mais exatamente, da pedagogia "poça de rãs". Enquanto os geógrafos se esgotam em discursos, em descrições monográficas, ou então [...], vendem a geografia através de um ecossistema emendado. O sistema GTP poderia, com alguns ajustes, ser esta ferramenta didática que falta à geografia. (BERTRAND, 2007, p.95)

Chegamos, finalmente, ao sistema GTP. Um novo projeto geográfico?

Bertrand, inquieto com certa unilateralidade de um conceito da Ecologia buscou, por meio da teoria geossistêmica, analisar a natureza sem deixar em segundo plano os elementos abióticos. Evidenciou a dimensão geoecológica da natureza e frisou a influência da exploração biológica na dinâmica do fato natural. Todos estes fatores alterados, ora direta ora indiretamente pela ação antrópica, realmente definiriam o centro reativo da paisagem.

Porém, Bertrand não parou por aí. Reconheceu a paisagem como um sistema cuja existência é proporcionada por um conjunto de sentidos/valores/representações diretamente relacionados a critérios de identidade e sedimentação cultural do indivíduo em si e da sociedade.

Assim, o sistema GTP (Geossistema, Território e Paisagem) vem ao encontro dos novos desafios diante das rápidas transformações econômicas, políticas e culturais, desdobradas em uma estimuladora questão socioambiental, apresentando grande complexidade e inviabilidade para ser analisada por meio de paradigmas unilaterais.

Para Mendonça:

A abordagem da problemática ambiental, para ser levada a cabo com profundidade e na dimensão da interação sociedade-natureza, rompe assim com um dos clássicos postulados da ciência moderna, qual seja, aquele que estabelece a escolha de apenas um método para a elaboração do conhecimento científico. Tal abordagem demanda tanto a aplicação de métodos já experimentados no campo de várias ciências particulares, quanto a formulação de novos. (MENDONÇA, 2002, p.136, grifo nosso) 
Em nossa avaliação, não pensamos os méritos da abordagem bertrandiana pelo simples fato de estar ligada à teoria dos sistemas capaz de relacionar "todas as coisas com tudo ou tudo com todas as coisas". Bertrand, sobretudo a partir da elaboração do sistema GTP, tem como preocupação central interpretar a natureza no viés do território e da paisagem de forma integrada e condizente à demanda por paradigmas abertos a complexidade dos fenômenos, procurando interpretá-los com devida coerência e fornecer respostas mais completas aos questionamentos que provocam.

Nesta perspectiva não há espaço para sistemismo. Há possibilidade para olhares plurifocais a partir de conceitos consagrados na Geografia e responsáveis pela própria definição dos objetivos desta ciência. Geógrafos existem porque falam de território e paisagem!

O território, conceito central da ciência geográfica, é considerado aqui [...] na sua dimensão natural. Ele é de alguma forma a interpretação socioeconômica do geossistema [...]. A dialética fonte-recurso fundamenta esta análise do território. Encontramos aqui então a família dos conceitos híbridos (potencialidade, limitação, meio ambiente, meio) [...].

A paisagem [...], permite aqui ao geógrafo aceder ao mundo das representações sociais da natureza assegurando ao mesmo tempo um elo, outros diriam uma conivência, com os objetos naturais em sua dimensão geossistêmica.

Trata-se de assumir, em plena luz, uma passagem multidirecional e interativa. Em um sentido, ela permite ir, por exemplo, no caso de um solo, de um fenômeno físico-químico bruto ("perfil pedológico") para sua interpretação socioeconômica ("perfil cultural") e sua representação social (fertilidade). No outro sentido, ele assegura a transição de um projeto socioeconômico (silvicultura) e de uma representação social (espaço verde) para um objeto natural (ecossistema florestal). (BERTRAND, 2007, p.113-114)

Portanto, a tríade GTP permite trasladar interpretações não excludentes umas às outras. Se a realidade fosse algo estanque, poderíamos dizer que por meio destes traslados apreenderíamos os fenômenos em sua totalidade. Para nossa satisfação, a realidade é dinâmica ${ }^{14}$, deixando-nos uma série de lacunas, exigindo-nos crescente empenho:

1) Na busca pelo conhecimento (em termos epistemológicos);

\footnotetext{
${ }^{14}$ Como se fosse uma espécie de "garantia a existência" do pesquisador.
} 
2) No desenvolvimento, apuração e aplicação de teorias e métodos;

3) Na definição e tratamento de termos e conceitos utilizados para sustentar as teorias e os métodos (ou seja, na atenção e cuidados que se deve tomar com a produção e utilização da linguagem científica).

7) GTP: um filtro de linguagem ou chave conceitual para entrada na análise da relação sociedade-natureza

Para Bertrand, a exploração geográfica da interface natureza-sociedade exige um método de complexidade e diversidade. Este método deve se situar no encontro de diferentes percursos, evitando, desta forma, ser unívoco/linear e trazendo em si a preocupação didática para ser operatório.

Na elaboração do sistema GTP, o autor tem como princípio trabalhar conceitos mistos no cruzamento de campos semânticos e disciplinares, pois considera que a maioria dos objetos, dos conceitos e das noções que encontramos pertence ao mesmo tempo ao campo cultural e ao campo social, ou seja, tratam-se de verdadeiras entidades polissêmicas. "Sobre as margens indefinidas da natureza e da sociedade, palavras se aglutinam ou derivam ao sabor das analogias científicas ou das proximidades lexicais". (BERTRAND, 2007, p.90)

Então, nos perguntamos: por que a necessidade de se trabalhar com a dubiedade dos conceitos dentro de um sistema multidirecional?

Bertrand nos responderia que um "sistema conceitual único, do tipo daquele empregado na Ecologia a partir do ecossistema, não permite varrer a totalidade da interface natureza-sociedade e de revelar sua diversidade". (2007, p.90) Assim, o caminho teórico seguido e proposto pelo autor perpassa por um sistema composto por três conceitos (ou noções) dominantes: geossistema, território e paisagem, agrupando ou reagrupando outras noções que assumem diversos sentidos de acordo com sua situação no âmbito do sistema GTP. 
Assim, este geógrafo expõe um método e uma reflexão epistemológica por meio da varredura lógica, hierarquizada e diferenciada da terminologia científica utilizada no tratamento da relação sociedade-natureza e questão socioambiental.

A partir de suas idéias, elaboramos um filtro de linguagem (ou chave conceitual em ordem crescente) na tentativa de exemplificar a maneira pela qual esta hierarquização semântica pode dar-se a partir de três conceitos (ou noções) fundamentais e se prestar como um indicativo da complexidade do tratamento geográfico da interface sociedade-natureza nos dias atuais. (esquemas 3, 4, 5, 6, 7 e 8 )

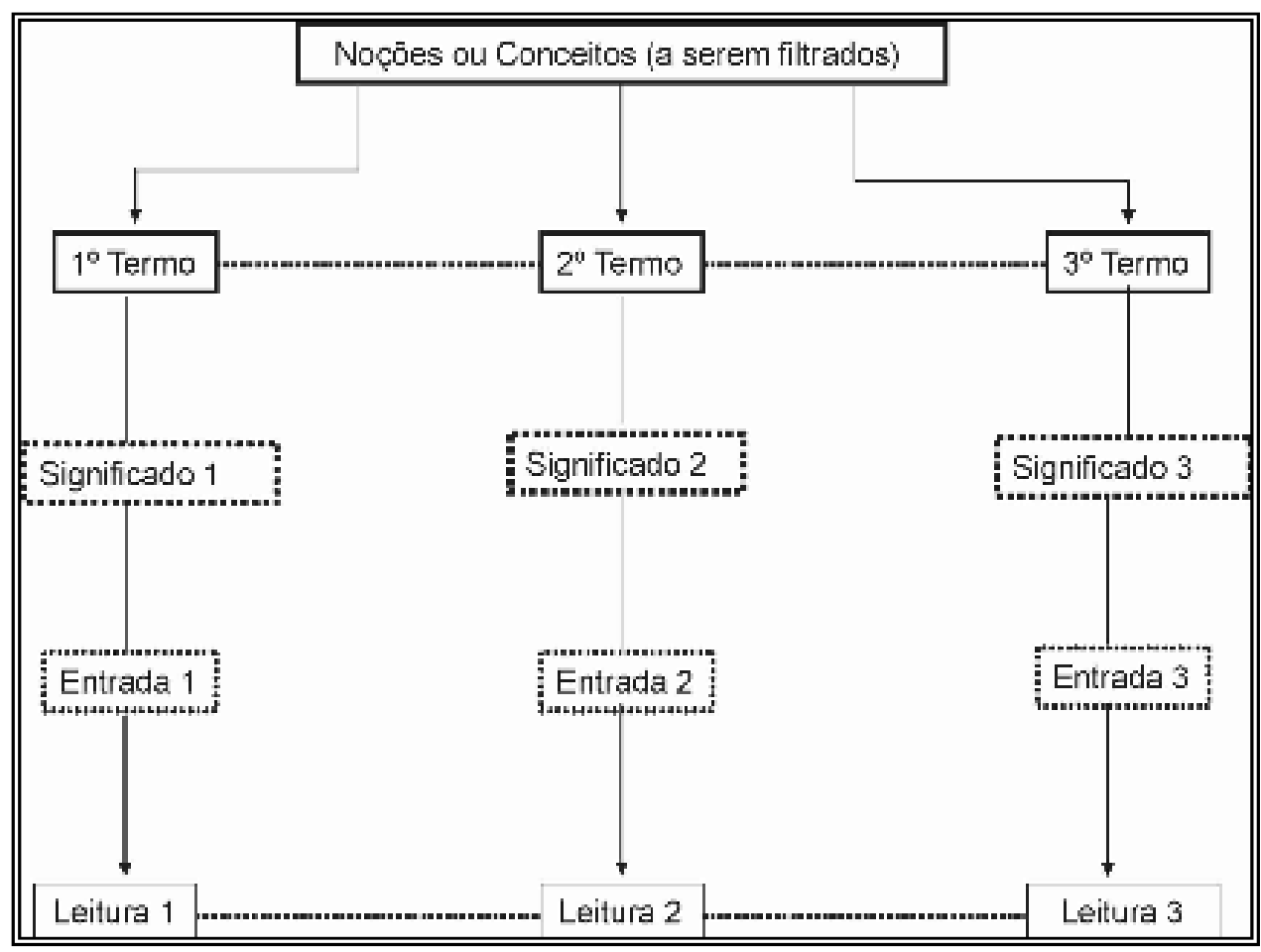

Esquema 3: Filtro de linguagem (ou chave conceitual) inicial. Org.: Reginaldo J. Souza.

A idéia central da elaboração deste filtro (ou chave) de linguagem é o enfoque em três tipos de leituras diferentes partindo-se de uma única noção ou conceito. Estas leituras estarão vinculadas aos diversos significados que podem tomar esta referida noção (ou conceito) se vislumbrados sob a ótica naturalista $\left(1^{\circ}\right.$ termo), territorial $\left(2^{\circ}\right.$ termo) ou paisagística $\left(3^{\circ}\right.$ termo) de acordo com o sistema tripolar proposto por Bertrand. 


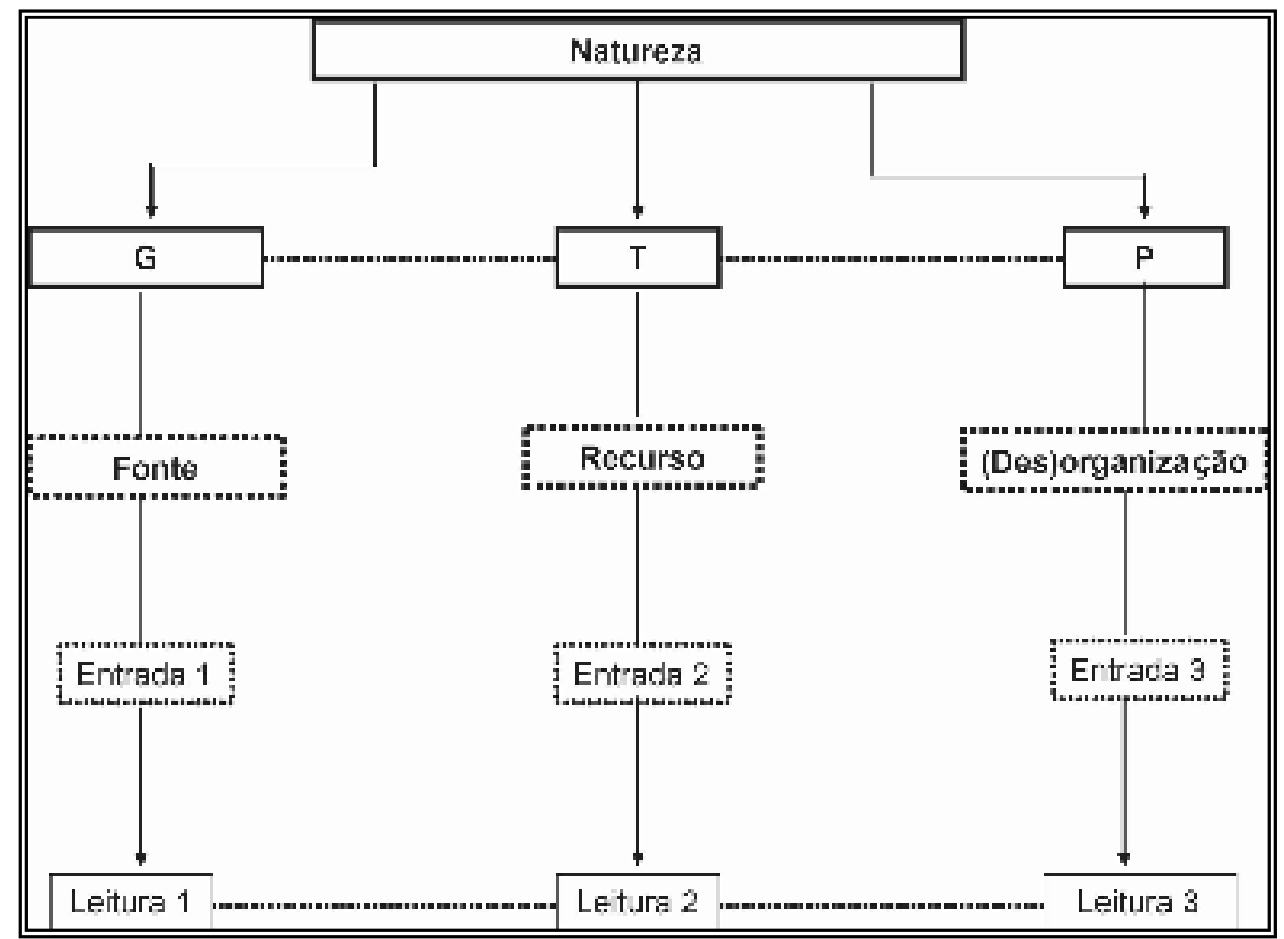

Esquema 4: Diferentes significados do conceito de natureza a partir da varredura semântica no sistema GTP. Org.: Reginaldo J. Souza

Primeiramente, tomamos como exemplo o conceito de natureza (ver esquema 4). Quando analisado sob o ponto de vista naturalista-geossistêmico, abre-se para a varredura lógica como fonte, como natureza espacializada. Sob a ótica do território, toma outra dimensão: aquela do recurso, afinal, "não há território sem terra" (BERTRAND, 2007, p.84) e neste sentido a natureza passa a ser vista como recurso essencial à própria existência de um determinado território. E, finalmente, ao "filtrarmos" ou "abrirmos" a natureza sob o ponto de vista da paisagem, é possível perceber seu caráter indicador das ações antrópicas desdobradas neste mesmo território que o leva ao estado de organização ou desorganização socioambiental e/ou socioeconômica.

Sendo possível captar estes aspectos do território, automaticamente nos remetemos a outro conceito: o de sociedade (não há território sem terra, muito menos 
sem pessoas!). Agrupando seus diferentes significados ao redor dos conceitos componentes do sistema GTP, temos a seguinte configuração:

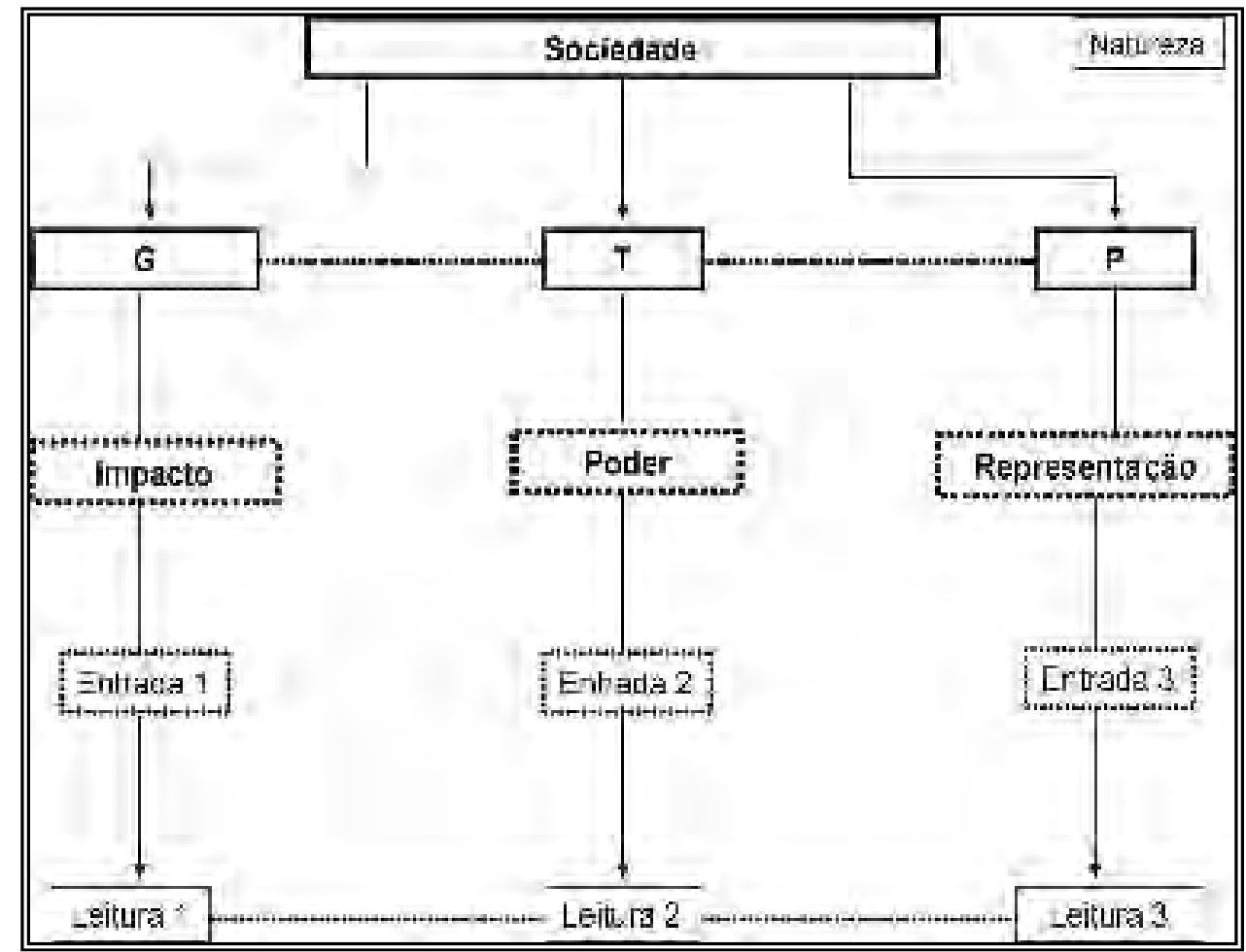

Esquema 5: "Filtragem" (ou "abertura") do conceito de sociedade no sistema GTP. A partir da natureza somos levados a pensar os desdobramentos da organização social no âmbito do território. Org.: Reginaldo J. Souza

A sociedade de um modo ou outro causando impactos naquilo que antes foi considerado como fonte (elementos naturais) e se tornou recurso. No viés do território, a sociedade se manifesta como expoente de relações de poder, gerando alterações no funcionamento dos elementos naturais e nas diferentes dimensões da organização social (economia, política, cultura). Sendo assim, na perspectiva da paisagem podemos entrar em contato com o mundo da subjetividade, da cultura, ou seja, da representação da sedimentação sócio-cultural no âmbito de um dado território.

Seguindo o raciocínio da hierarquização de conceitos e noções em torno do sistema GTP, poderíamos realizar a varredura de qualquer um dos termos anteriormente expostos (impacto, poder ou representação), a título de exemplo faremos a varredura da noção de impacto: 


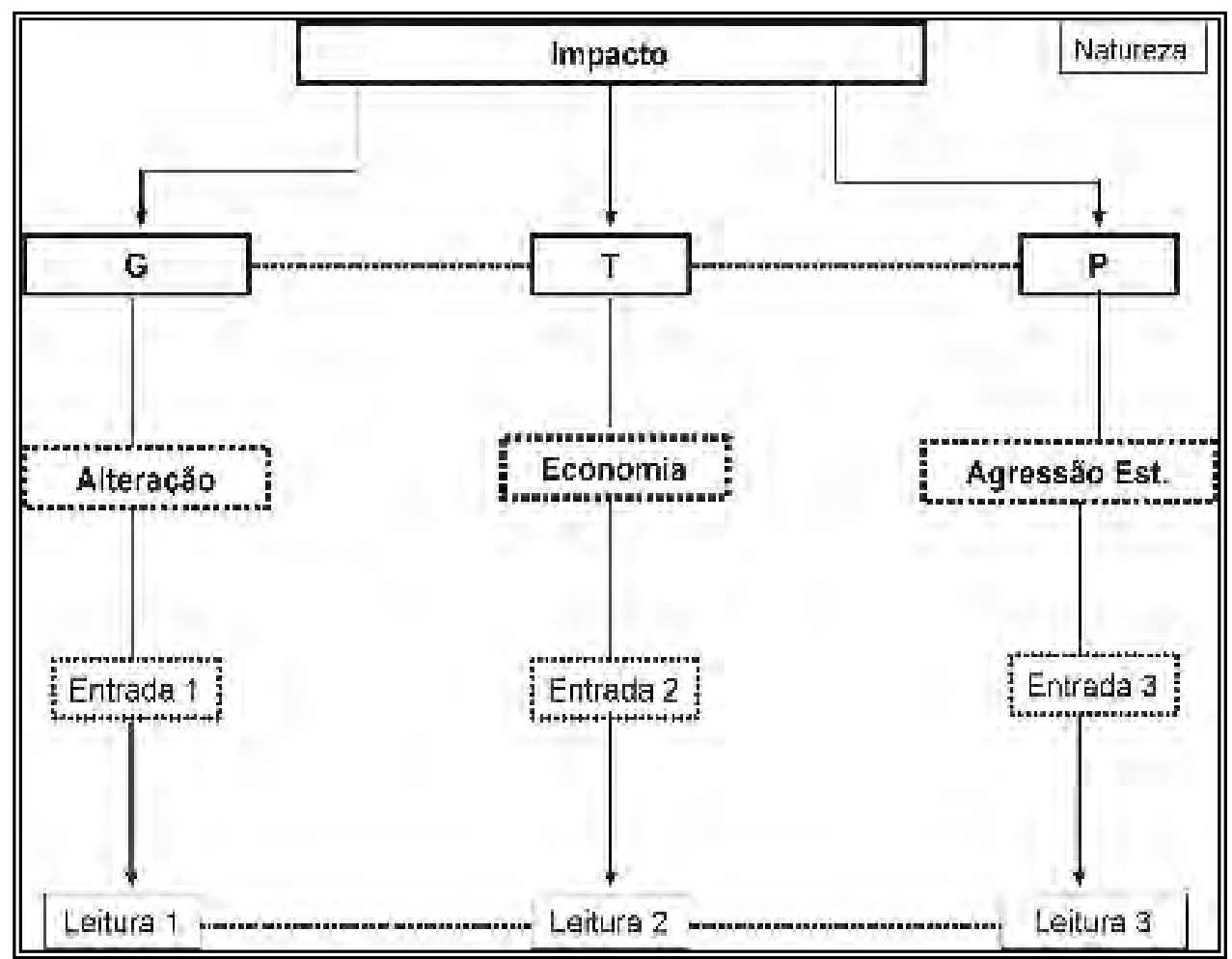

Esquema 6: “Filtragem" (ou "abertura") da noção de impacto no sistema GTP. O impacto pode gerar alterações nas dinâmicas naturais a medida que é originado no âmbito da exploração econômica da natureza em um dado território. Visualizamos o impacto por meio das paisagens, como uma agressão estética, por exemplo. Org.:

Reginaldo J. Souza.

O impacto altera a dinâmica natural em um determinado geocomplexo à medida que está vinculado à produção econômica no território. $\mathrm{O}$ impacto na paisagem pode ser considerado, entre outras possibilidades, a partir da agressão estética. Neste sentido, destacamos a importante dimensão que a paisagem toma neste jogo de relações como indicadora da sustentabilidade (ou não) dos usos econômicos intermediadores da relação sociedade-natureza. 
Ao pensarmos nas proporções de um impacto ambiental, somos levados a incluir em nossa perspectiva o local ${ }^{15}$ onde este impacto poderá ocorrer. A título de exemplo, salientaremos aqui o impacto incidente sobre o relevo.

O relevo, por sua vez, "filtrado" no sistema conceitual GTP, poderá ser lido como vertente na perspectiva geossistêmica ${ }^{16}$. Vertente apropriada cuja dinâmica poderá ser apreendida pela paisagem (indicadora de áreas mais ou menos degradadas).

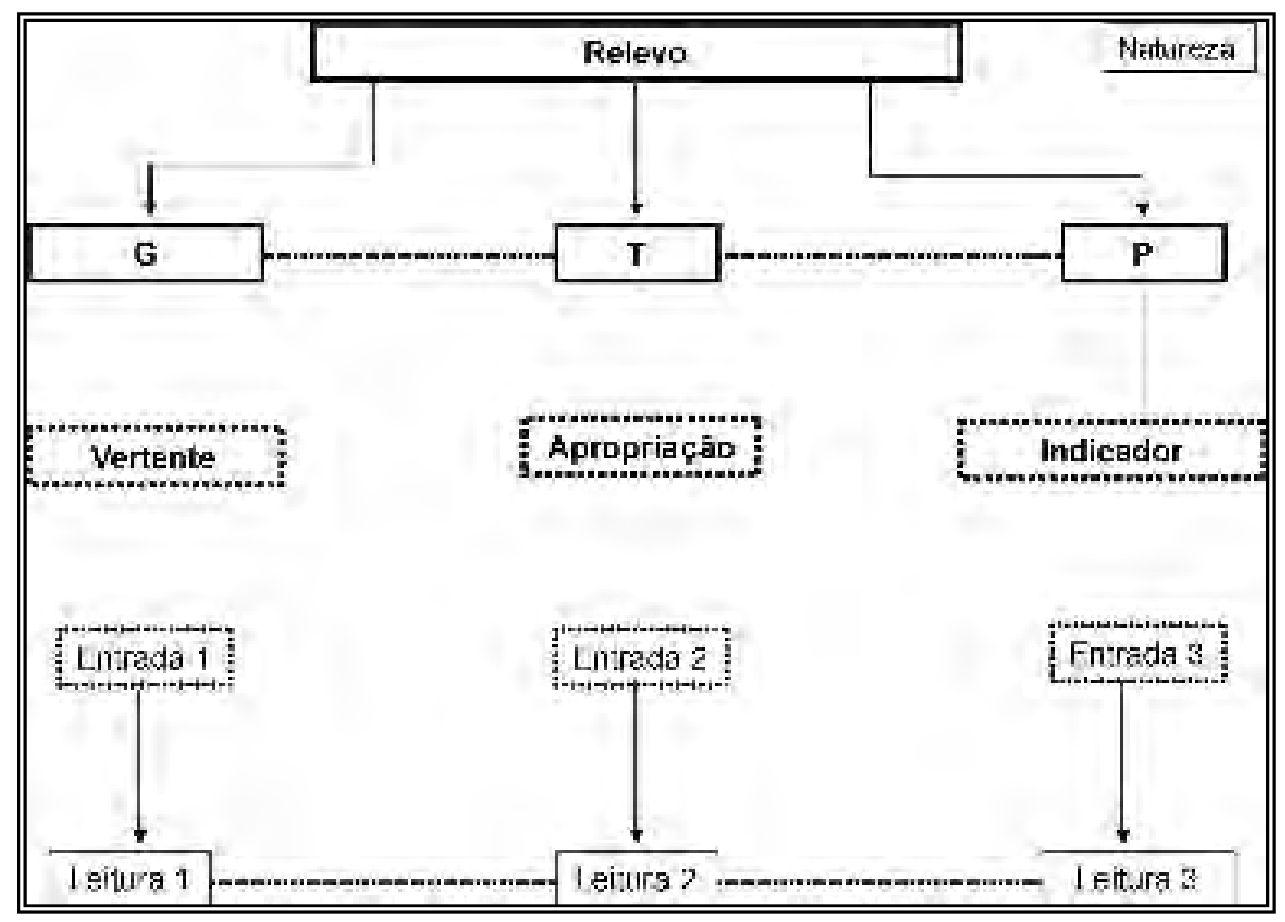

Esquema 7: "Filtragem" (ou “abertura") do conceito de relevo no sistema GTP. O relevo pode ser traduzido como vertente, do ponto de vista geossistêmico (poderia ser traduzido de outras formas de acordo com outros objetivos); como uma vertente apropriada por um dado grupo social na perspectiva do território. E, dependendo da forma como o grupo social irá transformar a vertente, a paisagem se prestará como uma indicadora das dinâmicas socioambientais. Org.: Reginaldo J. Souza.

Por meio destes diferentes significados assumidos pelo relevo em torno do sistema GTP, é possível incluir em nossa análise a categoria tempo (a existência das formas de relevo demandam certo período de tempo, por outro lado, o impacto sobre o relevo, um outro período).

\footnotetext{
15 Em um sentido semelhante ao de "palco".

${ }^{16}$ Apenas um exemplo.
} 


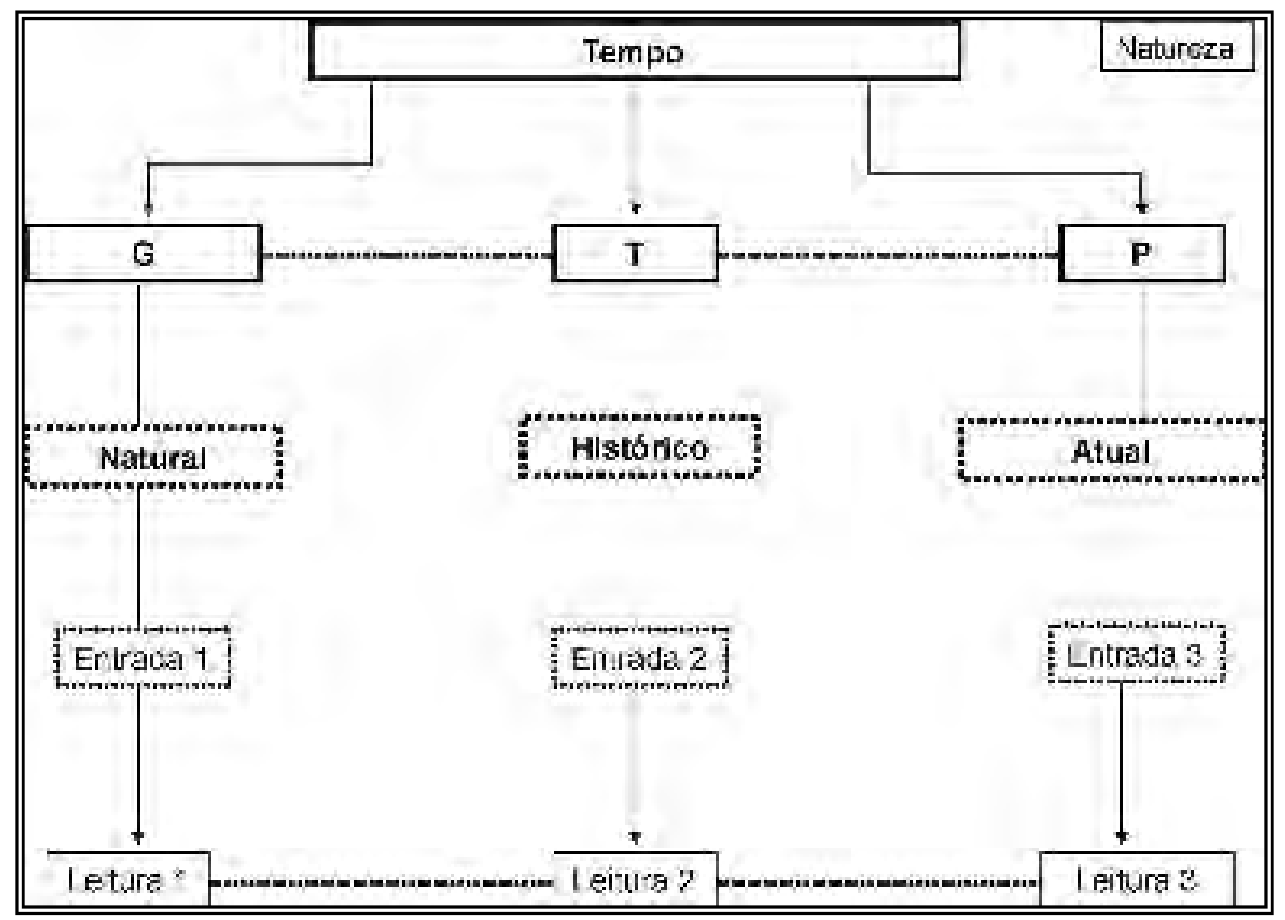

Esquema 8: “Filtragem" (ou "abertura") da categoria tempo no sistema GTP. A abordagem GTP dos fenômenos geográficos de interface possibilita o enfoque sobre diferentes (e conflitantes) dimensões de tempo que existem. Org.: Reginaldo J. Souza.

O tempo, neste contexto se apresenta em três formas diferentes: o tempo da natureza (necessário ao equilíbrio dos sistemas naturais, dos geocomplexos), o tempo histórico das sociedades (para a sedimentação de um território) e o tempo da atualidade (que confere movimento e sentido a uma paisagem).

Regra geral, estas três diferentes manifestações do tempo são conflitantes entre si, caracterizando a supressão do fato natural pelo social ou o contrário, isto é, o impacto ambiental ou a catástrofe ${ }^{17}$.

O nosso objetivo nesta demonstração é expor a pertinência do sistema GTP como um método capaz de fazer uma varredura lógica de categorias e conceitos híbridos e noções polissêmicas que dizem respeito à complexidade inerente não apenas à relação sociedade-natureza, mas também da exploração geográfica desta interface onde cada

17 O tempo necessário à formação de uma floresta, por exemplo, é diferente do tempo das ações de desmatamento e uso agropecuário da área desta mesma floresta. Isso caracteriza aquilo que estamos chamando de supressão do fato natural pelo social. Por outro lado, a passagem de um furacão ou erupção vulcânica em uma área urbanizada representa a preponderância dos ritmos da natureza sobre os ritmos da sociedade. 0 social é suprimido pelo natural, caracterizando a catástrofe. 
um dos três conceitos norteadores se prestam como filtros (ou chaves) de linguagem que expandem ou abrem a análise dos fenômenos por meio de três entradas e leituras diferentes e complementares ao mesmo tempo. O percurso metodológico deve objetivar a análise integrada. (ver tabela 2)

Nos últimos esquemas, mantivemos o primeiro conceito exposto - natureza - no canto superior direito de todos os boxes para não perdermos de vista que, a partir dele, estruturamos nossa linha de raciocínio. Poderíamos ter iniciado a filtragem (ou abertura) por tempo ou sociedade, por exemplo; de qualquer forma nos remeteríamos a um encadeamento cada vez mais abrangente porque os conceitos principais automaticamente nos levam às leituras multifocais dos outros termos geralmente utilizados pela ciência no tratamento da relação sociedade-natureza.

Tabela 2: Possibilidades de leituras geográficas de fenômenos a partir do sistema GTP: da análise unívoca (1 ou 2 ou 3) à análise integrada (1-2-3).

\begin{tabular}{|c|c|c|c|c|}
\hline Filtro ou Chave & $\begin{array}{c}G \\
\text { (Geossistema) }\end{array}$ & $\frac{T}{\text { (Território) }}$ & $\begin{array}{c}P \\
\text { (Paisagem) }\end{array}$ & Nível da Análise \\
\hline Entradas/Leituras & 1 & 2 & 3 & \\
\hline \multirow[t]{10}{*}{ Combinações } & 1 & 1 & 1 & \multirow{3}{*}{ Setorizada } \\
\hline & 2 & 2 & 2 & \\
\hline & 3 & 3 & 3 & \\
\hline & 1 & 1 & 2 & \multirow{6}{*}{$\begin{array}{l}\text { Parcialmente } \\
\text { Integrada }\end{array}$} \\
\hline & 1 & 1 & 3 & \\
\hline & 2 & 2 & 1 & \\
\hline & 2 & 2 & 3 & \\
\hline & 3 & 3 & 1 & \\
\hline & 3 & 3 & 2 & \\
\hline & $\overline{1}$ & 2 & 3 & Integrada \\
\hline
\end{tabular}

A análise geográfica dos fenômenos de interface pode ocorrer sob o prisma exclusivamente geossistêmico (abordagem unicamente naturalista, por exemplo, análises sem combinações). $\mathrm{Ou}$, um tratamento no viés do território, mas considerando a abordagem naturalista (por exemplo, análises flutuantes entre as dimensões 2 e 1). E, finalmente, uma abordagem que pretenda ser integrada, em que os estudos considerarão as dimensões 1, 2 e 3 concomitantemente. Org.: Reginaldo J. Souza 


\section{8) Algumas considerações}

A natureza não é mais o que ela era. A sociedade também não. Nesta dança de revoluções, nossos desafios enquanto pesquisadores aumentam diante das incertezas com relação às análises e conclusões sobre um objeto que nos propomos estudar. Tudo está se transformando permanentemente.

O sistema GTP emerge a partir de uma necessidade de mudança paradigmática na ciência geográfica, buscando entender os fenômenos entre natureza e sociedade de maneira integrada, onde geossistema, território e paisagem aparecem com significados e valores diferenciados, porém coexistentes e conferindo dinâmica àquilo que chamamos de espaço geográfico. (ver esquema 9)

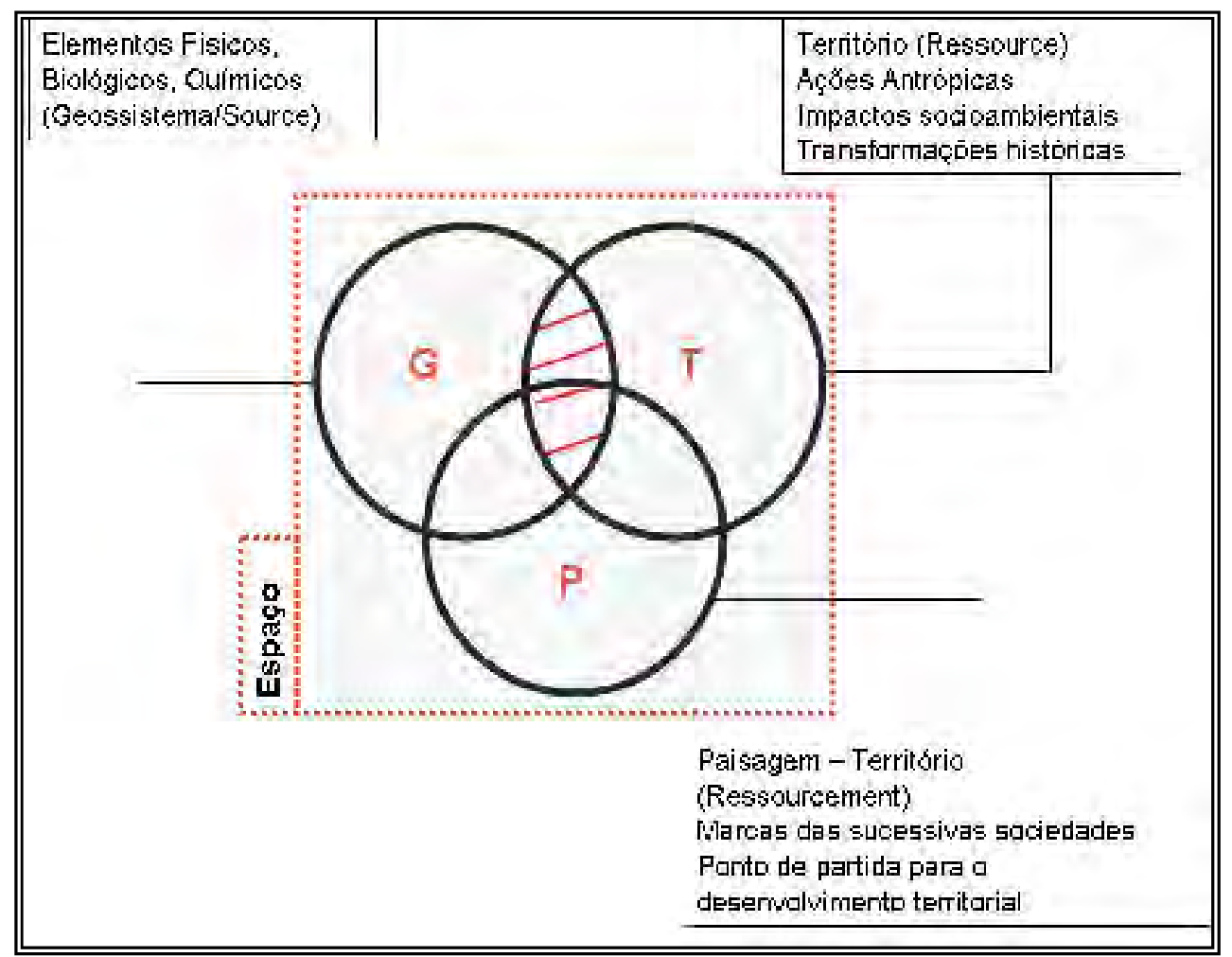

Esquema 9: Representação do sistema GTP, conforme a proposta de Georges Bertrand. (Fonte: BERTRAND, 2007. Org.: Reginaldo J. Souza) Cada uma das esferas representa um conceito - G (geossistema), T (território), P (paisagem). É no ponto de intersecção entre elas que deve se situar a análise geográfica. A convivência dinâmica destas esferas define $o$ e confere movimento ao espaço geográfico.

Além de um método, o sistema GTP vem ao encontro da relativa carência epistemológica característica da Geografia (bem como de outras ciências) no que tange às análises do meio ambiente. Uma proposta teórica ainda inacabada, porém, atenta à 
necessidade da inter ou transdiciplinaridade para a abordagem de fenômenos que se manifestam entre franjas de fatos naturais e sociais.

Sendo assim, consideramos a abordagem bertrandiana pertinente e relevante ao desenvolvimento das pesquisas de meio ambiente na Geografia como um todo. Para o desenrolar de nossa pesquisa, especificamente, este aporte teórico-metodológico atento à complexidade dos fenômenos esteve/está presente nas análises desde os momentos das saídas de campo até a elaboração do presente texto.

Podemos, certamente, afirmar que o sistema GTP é um novo projeto geográfico ao passo que propõe a integração como ponto de partida primordial ao estudo da realidade. A abrangência caracteriza sua essência.

Ao realizarmos uma leitura preliminar do quadro socioambiental do município de Mirante do Paranapanema, por meio do GTP, temos a seguinte configuração:

- Do ponto de vista naturalista, a dinâmica geral do potencial geoecológico é de resistasia. As áreas de mata ciliar, quando existem, estão em condições precárias denunciadas por sua incapacidade de minimizar o impacto das águas pluviais sobre os processos erosivos. Os ribeirões do município recebem as cargas de sedimentos das vertentes erodidas entrando em processo de anastomosamento que denotam sua franca degradação. O solo bastante friável proveniente da Formação Caiuá, associado a práticas pouco conservacionistas, potencializa este quadro na maior parte das áreas que visitamos durante nossos trabalhos de campo.

- Do ponto de vista da (des)organização territorial, percebemos a predominância, nos dias atuais, das pastagens tanto nas pequenas propriedades quanto nos assentamentos rurais destinadas, sobretudo, à pecuária leiteira. Por outro lado, nas grandes propriedades há inserção do plantio de cana-de-açúcar. Vale ressaltar que geralmente as áreas de pastos não conduzem a ganhos financeiros significativos capazes de dinamizar a economia do município. No caso da produção canavieira, esta situação não é muito diferente quando pensamos em termos de desenvolvimento local, embora não seja isso o que geralmente é "apregoado" pelos grupos interessados. O arrendamento de terras para este cultivo é interessante apenas para os grandes proprietários. Constatamos este fato por meio de trabalhos de campo onde entrevistamos alguns 
moradores do município (da bacia do ribeirão Santo Antônio). Eles alegam que os preços pagos pelas usinas são muito baixos, o que lhes gera um retorno não muito significativo.

- Do ponto de vista paisagístico, o quadro geral nos remete diretamente às dinâmicas socioambientais/territoriais de Mirante do Paranapanema. A paisagem apresenta relativa homogeneidade com predominância das áreas de pastagens e algumas propriedades com produção de cana-de-açúcar. Analisando-se pelo viés da estética paisagística podemos, sem nenhum tipo de apelo sensacionalista, usar o termo desolação. O exemplo deste quadro negativo é a própria "sobreposição histórica", se nos é permitido desta forma o definir, dos impactos gerados pela ação antrópica tanto no município quanto na região do Pontal do Paranapanema como um todo. A retirada da mata, a produção agrícola intensiva nas épocas do algodão e amendoim (entre os anos de 1940 e 1960), a ausência de práticas conservacionistas, o exaurimento do solo, assoreamento dos córregos, enfim, tudo isso esteve/está historicamente relacionado com a mentalidade imediatista que caracterizou os pioneiros desde os primeiros momentos da ocupação regional/local. As heranças destes processos estão delineadas na paisagem atualmente. A indiferença com relação ao manejo adequado dos recursos naturais ainda se faz presente: um exemplo assustador foi o envenenamento, no ano de 2008, de Áreas de Reserva Florestal Legal dentro de uma determinada fazenda entre os municípios de Mirante do Paranapanema e Presidente Bernardes. O objetivo era "limpar a terra" para o plantio de cana...

Existe uma correlação entre todos os processos que caracterizam, seja de modo negativo ou positivo, as dinâmicas socioambientais de um dado território. A sedimentação (ou não sedimentação) sociocultural, econômica e política da sociedade (tão necessárias à existência de um território) estão diretamente relacionadas à maneira pela qual esta agirá sobre o ambiente em que vive. A paisagem, neste sentido, irrompe como um híbrido entre homem e meio, entre sociedade e ambiente. Ela nos fornece elementos norteadores ao entendimento da problemática social, da ambiental, da socioambiental: entre a economia e a ecologia; entre as práticas quotidianas e os projetos (ou ausência de) de desenvolvimento; entre conhecimento científico/filosófico e sabedoria popular... 
Estas reflexões advêm de nossas leituras sobre a temática do meio ambiente na Geografia, principalmente da abordagem bertrandiana. $O$ enfoque sobre a processualidade dos fenômenos, e não somente em seus aspectos, está explícito na teoria de Georges Bertrand. Por isto o interesse por seus estudos: fonte de inspiração ao desenvolvimento deste trabalho.

\section{$\operatorname{son}$}

Feitas estas considerações a respeito de nosso referencial teórico metodológico, passaremos à reflexão sobre o sentido da temática fronteiriça no âmbito da ciência geográfica e especificamente da Raia Divisória São Paulo-Paraná-Mato Grosso do Sul. 


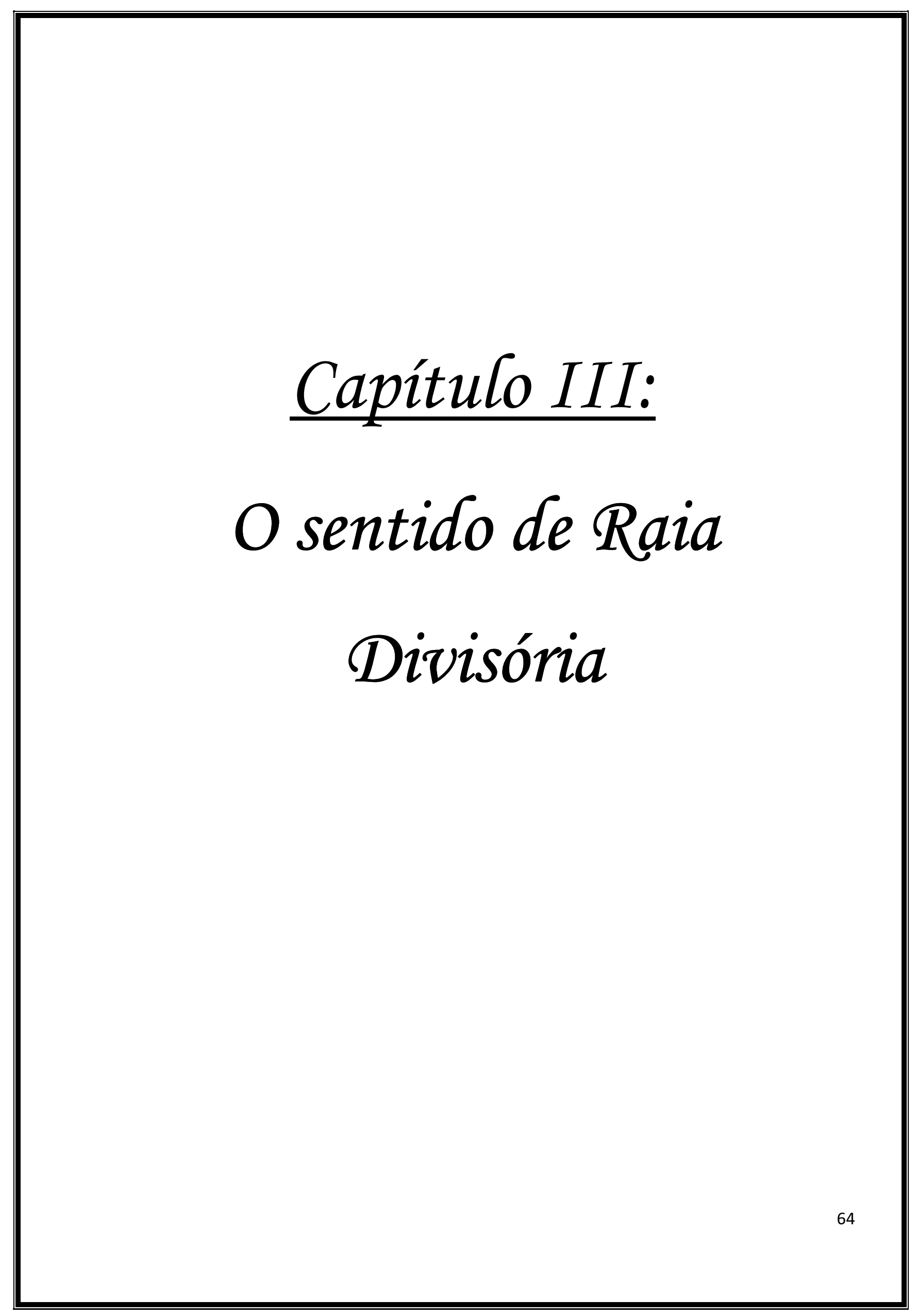




\section{Exce}

"O tema da fronteira, seja no âmbito cultural, geopolítico ou disciplinar, está sempre imerso numa problemática teórico-conceitual, envolta em certa nebulosa que nos impele a tatear o terreno instável do labirinto de reflexões que suscita".

(Flávio Leonel Abreu da Silveira)

8003 


\section{1) Notas introdutórias}

Neste capítulo discutiremos o tema da fronteira/da raia no âmbito da Geografia. Diante da dubiedade deste conceito, tomado ora como limite ora como elo de aproximação entre realidades/"mundos" diferentes, buscamos aprofundar nosso entendimento e ao mesmo tempo contribuir para o debate a respeito da importância desta temática no âmbito dos estudos geográficos voltados para a abordagem do meio ambiente em sua dimensão tanto territorial quanto paisagística.

O município de Mirante do Paranapanema está inserido em um conjunto regional mais amplo, o Sudoeste paulista ou Pontal do Paranapanema. A partir dos estudos de Passos (2005, 2006, 2007) e uma equipe de pesquisadores envolvidos no projeto temático "Dinâmicas Socioambientais, Desenvolvimento Local e Sustentabilidade na Raia Divisória SP-PR-MS", podemos dizer que o conjunto regional anteriormente mencionado encontra-se contextualizado no âmbito de um território interfronteiriço/interestadual.

Assim, a motivação para elaboração deste capítulo vinculou-se à necessidade de analisarmos a pertinência dos estudos sobre áreas fronteiriças/raianas como possibilidade para se iniciar discussões sobre o desenvolvimento local/regional de territórios localizados em zonas de contato, como é o caso do Pontal do Paranapanema e o município ao qual dedicamos nosso estudo.

\section{2) Fronteiras ou raias (?)}

Em um momento no qual a ciência geográfica segue o fluxo de profundos debates a respeito do rompimento de barreiras entre os diferentes ramos científicos e da emergência da interdisciplinaridade como forma de aprofundamento da compreensão daquilo que lhe é proposto como objeto de estudo, ela também se vê perante o desafio de constantes revisões, readequações ou reformulações de seu rol de teorias e métodos de investigação.

No quadro destes desafios, podemos sublinhar a necessidade de enfoques renovados sobre uma série de noções, conceitos ou categorias de análise incorporados 
ao discurso geográfico, conferindo-lhe corpo teórico, disciplinar, pedagógico e até mesmo um ponto de partida para a intervenção na realidade. Enfim, uma série de noções, conceitos ou categorias de análise que dão identidade à Geografia.

Estamos falando, portanto, de termos como espaço, território, região, paisagem, meio ambiente, natureza, tempo etc. Palavras que assumem significados específicos conforme os contextos científicos, filosóficos, literários etc. em que estão inseridas. No caso da Geografia, todas elas estão diretamente relacionadas aos objetivos dos geógrafos em compreender a dinâmica / a processualidade inerente à relação sociedade-natureza.

Uma relação aprioristicamente binominal, mas na qual está resguardada uma infinidade de elementos e aspectos impossíveis de serem apreendidos por meio de teorias unilaterais, visões centralizadoras e fragmentárias ou metodologias que passem neste mesmo percurso. A relação a qual nos referimos é tomada na forma escrita por apenas dois termos: sociedade (o primeiro), natureza (o segundo). Por isso a chamamos de relação aprioristicamente binominal.

Porém, ela não é. Em um fugidio olhar a posteriori é possível esmiuçar estes termos iniciais em vários outros, sejam eles: economia, política, cultura, globalização etc. (partindo-se do termo sociedade); elementos geológicos, ecológicos, biológicos, físicos, químicos etc. (partindo-se do termo natureza).

De um modo um pouco mais cauteloso, ainda é possível recair nos interstícios da relação sociedade-natureza, neste hífen posto entre ambos os pólos da relação; de modo que a partir dele podemos abstrair sobre outros tantos termos que neste entremeio surgem: impacto socioambiental, degradação, poluição, mudanças climáticas, áreas de risco etc. Sendo que todos estes, muito além de meros termos com significados imediatos, nos remetem a análises mais aprofundadas, principalmente por se tratarem de fenômenos que se desdobram no espaço geográfico, nos espaços produzidos pelas sociedades humanas, em regiões ou territórios, e se manifestam através das paisagens que se insinuam ao nosso olhar, ou nossos olhares.

A Geografia cada vez mais é impelida a dar especial atenção ao seu vocabulário constituído tanto por "verbetes" de utilização mais corriqueira e tradicional quanto aos 
novos "verbetes" que irrompem no contexto em que a ciência gradualmente vem tomando consciência da real complexidade da vida e do mundo e tende a romper com pressupostos tradicionais originados em contextos históricos muito anteriores.

E por que falamos aqui destes desafios que são postos à Geografia em um período dito de crise da modernidade e aberto como nunca à relevante reflexão epistemológica?

Porque é no atual contexto científico que se vem dando cada vez mais atenção à elaboração de novas propostas teórico-metodológicas onde não nos é mais permitido deixar escapar o caráter híbrido de importantes noções, conceitos e categorias da análise geográfica.

Até o presente instante não incluímos, premeditadamente, o "verbete" fronteira entre os outros anteriormente citados em nossa exposição. Fronteira é igualmente uma palavra híbrida/polissêmica (do mesmo modo que paisagem, território, ambiente...), possuidora de diferentes significados conforme os textos e contextos nos quais ela se encaixa: fronteiras do conhecimento, fronteiras políticas, fronteiras culturais, fronteiras disciplinares, fronteiras psicológicas, fronteiras agrícolas etc.

No discurso geográfico da atualidade, a concepção de fronteira (ou fronteiras) também entrou na esteira das reflexões sobre o vocabulário que sustenta análises referentes a esta temática, sobretudo quando ela se associa aos conceitos gerais de espaço ou território, por exemplo, gerando os "espaços fronteiriços" ou os "territórios fronteiriços" e adquirindo forte conotação política vinculada à questão do exercício de poder no âmbito de um governo central.

Nas reflexões de Hissa, encontramos uma interessantíssima definição:

Sabe-se: a fronteira é transição, é espaço vago, é "terra de ninguém", também pronta para ser invadida e ocupada. Fronteira é o mundo do tênue, do frágil, do constantemente solucionado, dissolvido, para, em seguida, ser questionado. Fronteira é fio fraco, mas é expressão de formas de poder. Por isso chama para si, insistentemente, as palavras e os gestos da guarda e da proibição. Por isso pede o muro, para externalizar a concretude que não tem. É limite e margem, sendo ainda faixa de contatos e conflitos. Fronteira é, também, por isso, convite à ultrapassagem, é zona de litígio e de interpenetração de geografias. Fronteira é reflexão sobre o infinito, sobre o que não responde ao limite, 
sobre o que não cabe no território demarcado. (HISSA, 1998, p.55, grifo nosso)

Esta definição nos remete a pensar sobre a fronteira enquanto algo que ultrapassa a simples idéia de limite, embora este seja um elemento tido como sinônimo daquela primeira palavra (fronteira). Salientamos a expressão "interpenetração de geografias" justamente por considerarmos esta concepção a mais adequada para a nossa ciência, cuja atenção maior se volta para apreensão dos fenômenos em suas manifestações espaciais. Uma fronteira implica um limite, mas ela não é apenas o limite. Trata-se de uma área em que diferentes realidades convivem numa dinâmica de influências / de trocas onde o simbolismo do limite (a divisão político-administrativa entre dois Estados, por exemplo) pode até mesmo perder totalmente o seu sentido.

Sobre as diferenças entre fronteiras e limites do ponto de vista geopolítico, temos em Machado o seguinte:

\begin{abstract}
A fronteira está orientada "para fora" (forças centrífugas), enquanto os limites estão orientados "para dentro" (forças centrípetas). Enquanto a fronteira é considerada uma fonte de perigo ou ameaça porque pode desenvolver interesses distintos aos do governo central, o limite jurídico do estado é criado e mantido pelo governo central, não tendo vida própria e nem mesmo existência material, é um polígono. [...] o limite não está ligado à presença de gente, sendo uma abstração [...]. [...] a fronteira pode ser um fator de integração, na medida em que for uma zona de interpenetração mútua e de constante manipulação de estruturas sociais, políticas e culturais distintas [...]. (MACHADO, 1998, p.42, grifo nosso)
\end{abstract}

Os trechos dos textos anteriormente apresentados são bastante ilustrativos de um enfoque mais abrangente sobre noção de fronteira no âmbito da Geografia, ou seja, já existe uma abordagem que a amplifica, atenta as suas diversas facetas, seus diferentes ecos, indo muito além de uma concepção pouco produtiva: aquela da fronteira como barreira, como separação de Estados. Com certeza esta visão não está errada, porém, é importante dizer que ela não é, em si, suficiente para o estudo de territórios que se encontram em zonas de contato.

Podemos afirmar que à fronteira (ou às fronteiras) é inerente uma dualidade: embora demarque o limite entre realidades diferentes, ela também se abre como 
possibilidade para que em algum momento e situação (tempo e espaço) "mundos" desiguais tornem-se mais ou menos semelhantes entre si.

Fronteiras são leves franjas. Frágeis membranas entre uma territorialidade e outra. Elas próprias podem se constituir em um novo território com peculiaridades que não condizem necessariamente aos contextos de seus respectivos governos centrais (isto se pensarmos, por exemplo, em termos de geopolítica).

Silveira nos lembra que:

As fronteiras sempre implicam um nível relacional, evidenciado pela interação de diferenças, sejam elas quais forem. Portanto, se a fronteira existe é porque há uma dimensão membranosa, permeável ou porosa, possibilitando o trânsito de elementos diversos, que traz consigo um caráter marcadamente seletivo, pois é da "natureza" da fronteira que por ela ocorra a passagem, o fluxo ou a interdição. Trata-se assim de diversas formas de fluxos: de pessoas, de idéias [...], de substâncias, estados de consciência, objetos e, aliado a tal dinamismo, tudo o que isso representa na configuração de mais complexidade ou mesmo de construção e dispersão de sentidos no mundo. (SILVEIRA, 2005, P.18, grifo nosso)

Fronteiras expõem complexidades sociais. Exibem fluxos inter-territoriais de pessoas, mercadorias e informações. São áreas de influências culturais ora mais ora menos intensas. Esta complexidade de eventos sociais ocorre sobre um igualmente complexo conjunto de elementos naturais. Limites naturais estão contidos nas áreas de fronteiras, muitas vezes eles próprios são, erroneamente (talvez), tomados como sendo a própria fronteira (o rio, a montanha).

Por outro lado, as fronteiras podem se estabelecer sobre bases semelhantes do ponto de vista geoecológico. Algumas vezes estas semelhanças naturais se prestam, inclusive, como possibilidade de aproximação política, econômica e cultural entre os territórios.

Existem questões sociais nas fronteiras. Existem questões ambientais, também. A fronteira é, portanto, locus de dinâmicas socioambientais e se presta para a análise geográfica enquanto tal.

Diante do que foi exposto, concluímos que fronteira é uma palavra vaga / imprecisa justamente porque adquire diferentes significados conforme o contexto em 
que é inserida. No caso específico do discurso geográfico, sua indeterminação se insinua em diferentes facetas, ou seja, quando:

- Contém e ao mesmo tempo extrapola a idéia de limite, barreira, divisa;

- Simboliza aproximação ou afastamento entre realidades / "mundos" diferentes;

- Marca a diferença entre dois ou mais territórios ao mesmo tempo em que se constitui num terceiro ou quarto território em uma zona de contatos;

- É uma complexidade socioambiental porque paisagens são produzidas de modos diferenciados conforme as sociedades incorporam os elementos da natureza enquanto recursos para a produção e reprodução dos territórios.

Após todas estas reflexões, emerge um novo questionamento: qual é a diferença entre as palavras fronteira e raia? Imediatamente poderíamos responder da seguinte forma: nenhuma.

Passos (2006) assim define:

[...] "fronteiras" são raias, isto é, áreas de intergradação nas quais os processos se manifestam segundo uma lógica de descontinuidade objetiva da paisagem ou, ainda, segundo uma impermeabilidade muito acentuada entre as parcelas do território submetidas às definições e redefinições territoriais mais ou menos independentes. (PASSOS, 2006, p.13-14, grifo nosso)

Além do mais, o "uso da palavra raia sugere um espaço integrado, cuja evolução contempla a participação dos agentes e dos atores no seu todo - na raia" (PASSOS, 2007, p.299), ou seja, trata-se basicamente de um sinônimo. Isto se constata, sobretudo, pela utilização do adjetivo "integrado" (ao se referir a espaço) e do substantivo "todo" (ao se referir à raia) presentes na definição do autor mencionado, condizendo perfeitamente à abordagem aprofundada do conceito de fronteira no âmbito do discurso geográfico da atualidade.

Novamente: raia e fronteira são sinônimos. Isto, de forma muito simples, é perfeitamente verificável através de mera consulta a um dicionário da língua portuguesa. Mas é interessante destacar que não é comum encontrarmos o termo raia corriqueiramente utilizado pela literatura na Geografia brasileira. Talvez por este fato 
ambas as palavras pareçam guardar diferenças profundas entre si, sendo que unicamente se trata, isto sim, de usos de sinônimos em contextos diferentes.

Obviamente não podemos ignorar o contexto em que o termo raia é freqüentemente utilizado, trataremos deste assunto em seguida.

\section{3) O contexto luso-espanhol}

Espaços fronteiriços. Regiões fronteiriças. Áreas de intergradação de processos/fenômenos. Descontinuidades objetivas da paisagem. (Cf. PASSOS, 2006, p.13) Todos estes termos contribuem para a compreensão daquilo que se define como raia divisória no âmbito dos estudos geográficos da atualidade.

Contribuem porque nos remetem à idéia de certa ambigüidade ou hibridação de processos que se manifestam no espaço geográfico e nele imprimem suas marcas, diversificando-o, conferindo-lhe uma dinâmica geral da qual se resguarda as especificidades de diferentes regiões, territórios e lugares com suas lógicas e formas de organização direta ou indiretamente relacionadas.

Para a prática e o discurso geográficos, o significado de raia extravasa sua vinculação aos sinônimos de "limite" ou "linha" tomados no sentido de extensão ou, grosso modo, como marcos rígidos entre o término de uma área sob determinado domínio político-administrativo e o início de outra.

Fronteira implica descontinuidade política, administrativa, jurídica, ideológica e econômica, forças disjuntivas, dificuldades de circulação, desequilíbrios e aberrações na ocupação e ordenamento do espaço. Raramente a raia se confunde geograficamente com uma simples linha divisória, uma extrema [...]. (CAVACO, 1997, p.160, grifo nosso)

O enfoque sobre a importância dos territórios fronteiriços (das raias) subjaz a um dos princípios tradicionais da ciência geográfica: a nomeação, classificação e delimitação regional. Este princípio sempre esteve baseado em diferentes critérios de acordo com as acepções próprias a cada escola de pensamento e seus respectivos pesquisadores. 
Os critérios carregam em si diferentes perspectivas de regionalização da superfície terrestre, seja pelo viés da configuração/distribuição de elementos do meio natural, da herança histórica e cultural de um povo, do nível de desenvolvimento econômico ou da finalidade político-administrativa. Regra geral, unidades regionais foram apreendidas e delimitadas por meio destes critérios que, por sua vez, estiveram ligados à idéia de relativa homogeneidade caracterizadora de uma determinada área/região.

Por outro lado, a identificação de uma raia fronteiriça parte da análise da transição enquanto processo e/ou propriedade associada aos conceitos gerais de espaço, território, região e, inclusive, de paisagem: complexos fenômenos naturais e sócio-espaciais se desdobram nas interseções daquilo que, em princípio, se tem como unidades regionais ou territoriais diferenciadas, fazendo com que seus limites adquiram caráter de raias.

Conforme Passos:

Os termos "regiões fronteiriças", "espaços fronteiriços", "raia transfronteiriça" são pouco utilizados pela geografia brasileira. Utilizamos as unidades administrativas, as microrregiões propostas pelo IBGE; são mais práticas, sobretudo, quando há necessidade de se trabalhar com dados estatísticos. (2006, p. 13)

Então, para entendermos o contexto da utilização mais comum do termo raia, somos remetidos à realidade européia em que a diversidade de culturas e suas territorialidades colidem e/ou convivem no quadro de um continente recortado em inúmeros países (com suas regiões e localidades, enfim, suas particularidades socioeconômicas, políticas, culturais e ambientais) cujas dimensões são relativamente pequenas se comparadas à proporção do território brasileiro, por exemplo.

Desta forma,

No quadro de programas de desenvolvimento local e regional da União Européia (INTERREG - Programa de Cooperação entre Regiões; FEDER - Fundo Europeu de Desenvolvimento Regional etc.) é dada atenção especial às áreas de fronteiras: Portugal-Espanha; Espanha-França etc. (PASSOS, 2006, p.13) 
A atenção especial dispensada às áreas fronteiriças na Europa certamente vai ao encontro das permeabilidades entre os territórios neste continente, sobretudo com a unificação dos mercados (União Européia) e políticas para o desenvolvimento do setor dos transportes, da indústria, da agricultura e da articulação dos sistemas urbanos nestas áreas.

Com a entrada de Portugal e da Espanha na Comunidade Européia, em 1986, verificou-se um forte incremento das relações entre os países. Simultaneamente, o papel das regiões e das políticas regionais é valorizado com a conseqüente intensificação das relações entre regiões e, em particular, das regiões fronteiriças. As orientações políticas da União Européia para o próximo Quadro Comunitário de Apoio (2007-2013) reforçam esse papel e constituem, simultaneamente, um desafio para os territórios de fronteira [...]. (Estudo para o território de fronteira da Beira Interior Norte - Salamanca, 2005, p. 3)

A respeito de tais políticas, podemos citar como exemplo o Programa Operacional de Cooperação Transfronteiriça Portugal-Espanha, 2007-201318 (no âmbito do INTERREG-Programa de Cooperação entre Regiões) cujo objetivo geral é reforçar a coesão econômica e social do espaço de fronteira luso-espanhola. Suas prioridades e metas são estabelecidas para o desenvolvimento de 17 unidades territoriais ${ }^{19}$ que compõem a chamada Raia Ibérica. Estas unidades territoriais cobrem uma superfície total de $136.640 \mathrm{Km}^{2}$ (23,5\% do espaço ibérico) e contam com uma população de 5.474.225 habitantes entre Portugal e Espanha.

A preocupação, em termos de políticas públicas, sobre os espaços fronteiriços nesta região da Europa ${ }^{20}$ é, portanto, tomada a partir da pertinência no enfoque sobre a raia enquanto ponto de partida ao estabelecimento de metas voltadas a sua dinamização socioeconômica, pois:

A fronteira não é apenas o limite simbólico duma comunidade, unida por elementos comuns e interiorizados, em oposição ao Outro, mas é

\footnotetext{
18 Documento final preliminar para aprovação pela Comissão Européia, datado de 27 de maio de 2007 (Direção Geral de Desenvolvimento Regional, Portugal; Direção Geral de Fundos Comunitários, Espanha).

${ }^{19}$ Em ambos os lados da Raia Ibérica, estas unidades territoriais se dividem da seguinte forma: a) Portugal: Minho-Lima, Cávado, Alto Trás-os-Montes, Douro, Beira Interior Norte, Beira Interior Sul, Alto Alentejo, Alentejo Central, Baixo Alentejo e Algarve; b) Espanha: Pontevedra, Ourense, Zamora, Salamanca, Cáceres, Badajoz e Huelva. Fonte: Programa Operacional de Cooperação Transfronteiriça Portugal-Espanha, 20072013.
}

${ }^{20}$ Tomando a raia luso-espanhola como exemplo. 
espaço de encontros, de influências, de relações, de trocas, de cumplicidades, de cooperações e solidariedades, pela situação nas extremas, nos confins dos territórios e das soberanias nacionais.

À fronteira correspondem faixas de território cuja identidade deriva da sua localização raiana, da "sombra" da fronteira, dos "efeitos de fronteira", umas vezes recessivos e outras dinâmicos, em termos econômicos, sociais, culturais, ideológicos. A fronteira induz actividades e funções, defensivas e de controlo das trocas e das migrações humanas, ou de resposta a mercados mais vastos de bens e serviços. A abertura da fronteira tende a apagar aquelas, com os correspondentes impactos econômicos, sociais, de ordenamento do território, mas potencializa acções comuns de melhoria do quadro de vida, criação de infraestruturas e equipamentos, desenvolvimento sócio-econômico e cultural, novas complementaridades, interdependências e equilíbrios locais e regionais. (CAVACO, 1997, p.159-160, grifo nosso)

Estas considerações a respeito da abordagem dos espaços fronteiriços enquanto raias, nos países europeus, nos leva a refletir sobre a pertinência da utilização deste termo para a compreensão de certas dinâmicas sócio-espaciais no Brasil como um todo, não apenas considerando as áreas limítrofes intermunicipais, interestaduais ou internacionais.

Segundo Passos:

No Brasil, encontramos várias raias que reclamam uma análise no sentido de revelar suas potencialidades paisagísticas e suas peculiaridades culturais, sociais e econômicas, objetivando a implantação de planos de desenvolvimento regionais, capazes de superar o estágio de periferia a partir de uma gestão territorial (aménagement ${ }^{21}$ ) que contemple acima de qualquer "modismo globalizante", a integração regional. (PASSOS, 2006, p.14, grifo nosso)

Alguns exemplos de raias no Brasil são definidos pelo referido autor (PASSOS, 2006, p.14-15). Dentre os mais interessantes, podemos mencionar:

- Vale do Rio Grande, Oeste do Estado da Bahia: raia na qual se manifestam dois domínios morfoclimáticos distintos (caatinga e campos gerais) e ocorrem dois modelos de ocupação baseados, respectivamente, na cultura dos "sertanejos", seguindo um padrão tradicional e confinado e dos "sulistas", que ali implantaram a monocultura da soja a partir da década de 1970.

${ }^{21}$ Do francês aménager (disposer avec ordre / dispor com ordem). Nota do autor. 
- Região Centro-Oeste: a partir da década de 1920, várias porções ao longo dos vales dos rios de médio e grande porte na região tornaram-se palco para a atividade pecuária exercida por criadores mineiros e paulistas. Por outro lado, os chapadões areníticos foram incorporados, após a década de 1970, pela agricultura mecanizada (soja, milho, algodão) implantada por "sulistas" conforme o avanço da fronteira agrícola. Ou seja, estes padrões diferenciados passaram a constituir uma raia ora mais ora menos permeável ao longo dos anos.

Ainda nesta região, entre os municípios de Rondonópolis (pecuária e produção de soja), Primavera do Leste (produção de soja) e Poxoréo (garimpo de ouro e diamante) - municípios vizinhos localizados no Estado do Mato Grosso - sinais da existência de uma raia são evidenciados com a presença de processos de intergradação dos elementos envolvidos na gestão deste território.

- Raias no Estado do Paraná: a) na área de confluência do Rio Piquiri com o Rio Paraná, abrangendo a área de Salto del Guayra/Paraguai - Guaíra/PR - Mundo Novo/MS, sobretudo com a conclusão da ponte sobre o Rio Paraná (3.598m de extensão); b) a raia transfronteiriça, abrangendo territórios brasileiros, argentinos e paraguaios, ou seja, a região de Foz do Iguaçu e, por fim:

- A raia constituída pelo extremo Sudoeste Paulista (Pontal do Paranapanema), Noroeste Paranaense (microrregião de Paranavaí) e Sudeste do Mato Grosso do Sul (a Raia SP-PR-MS), foco de nossa discussão a partir deste momento.

\section{4) A Raia Divisória São Paulo-Paraná-Mato Grosso do Sul}

Conforme apresentamos anteriormente, existe uma série de raias no Brasil que reclamam abordagens científicas que permitam potencializar o desenvolvimento destes territórios de modo integrado. Para que estas raias sejam caracterizadas enquanto tais, elas prescindem que sua localização esteja estritamente vinculada a limites intermunicipais, interestaduais ou internacionais: o fator político-administrativo é um entre tantos outros 22 que podem levar a descontinuidades objetivas da paisagem,

\footnotetext{
22 Fatores socioeconômicos e culturais, por exemplo.
} 
produzindo e reproduzindo áreas de intergradação de processos/fenômenos entre os territórios.

No caso específico da Raia Divisória SP-PR-MS, esta é composta pela microrregião de Paranavaí/PR, Sudoeste de São Paulo (Pontal do Paranapanema) e Sudeste Sul mato-grossense (ver figura 2, pg.78). Três territórios, cada qual com suas particularidades no que diz respeito às formas de ocupação e desenvolvimento de atividades econômicas sobre o potencial geoecológico.

A Raia Divisória SP-PR-MS constitui a convergência de três formas distintas de ocupação/colonização bem definidas segundo a própria divisão político-administrativa, que criaram três diferentes formas de se construir a paisagem regional. Ao mesmo tempo as condições naturais funcionaram, em épocas diferentes, para que os tipos de ocupação/colonização se dessem de formas diferenciadas. Obstáculos como a dificuldade de travessia entre os dois grandes rios, Paraná e Paranapanema - limites naturais entre as três zonas -, assim como a qualidade dos solos, propícia ou não às culturas da época, são alguns dos fatores que acabaram por privilegiar ou por retardar a integração de certas áreas ao sistema produtivo. (DIAS, 2003, p.7, grifo nosso)

Uma região fronteiriça na qual se materializaram (se materializam) diferentes modos de construção da paisagem ao longo do tempo. Afirmamos que estas diferenças paisagísticas estão fortemente relacionadas ao parcelamento e aos tipos de uso do solo conforme o processo de ocupação do território em cada uma das porções.

Enquanto segmento da superfície terrestre apresenta suas peculiaridades. Caracteres únicos que nos levarão, no decorrer do capítulo, a interpretá-los sob o ponto de vista da construção de sua (s) paisagem (ens).

À guisa de localização do que é definido como Raia Divisória SP-PR-MS, anteriormente citamos as parcelas territoriais que a compõem (Noroeste paranaense, Sudoeste paulista e Sudeste Sul mato-grossense). A construção histórica da paisagem em cada uma destas parcelas obedeceu a momentos diferenciados conforme o nível de permeabilidade das influências (avanço da frente pioneira, estabelecimento das atividades agropecuárias, fluxos migratórios) que entre uma área e outra se fizeram presentes. 
O início da ocupação/colonização regional se deu pela parcela correspondente ao território paulista com o avanço da fronteira agrícola subjacente ao binômio cafeicultura-ferrovia.

Os "plantadores e pioneiros" do oeste paulista caminharam junto à linha de ferro que se estabeleceu ao longo dos espigões. Foram surgindo, assim, cidades como Presidente Prudente (1917), Presidente Bernardes (1919), Santo Anastácio (1920), Presidente Venceslau (1921) e Presidente Epitácio (1922), esta última na barranca do Rio Paraná. Dessa forma, a porção mais Sudoeste, distante da ferrovia, ficou marginalizada e vagamente denominada Pontal. (PASSOS, 2007, p.16. grifo nosso)

O principal determinante da ocupação regional - leia-se Oeste e Sudoeste paulista -, no início do século XX, foi o avanço da fronteira agrícola motivado pelo café, onde esta produção era favorecida em uma determinada conjuntura econômica nacional e internacional. Aliado a isto esteve o fato das terras anteriormente utilizadas nas outras regiões do estado apresentarem sinais de saturação. A devastação das matas tornou-se algo comum a partir deste momento.

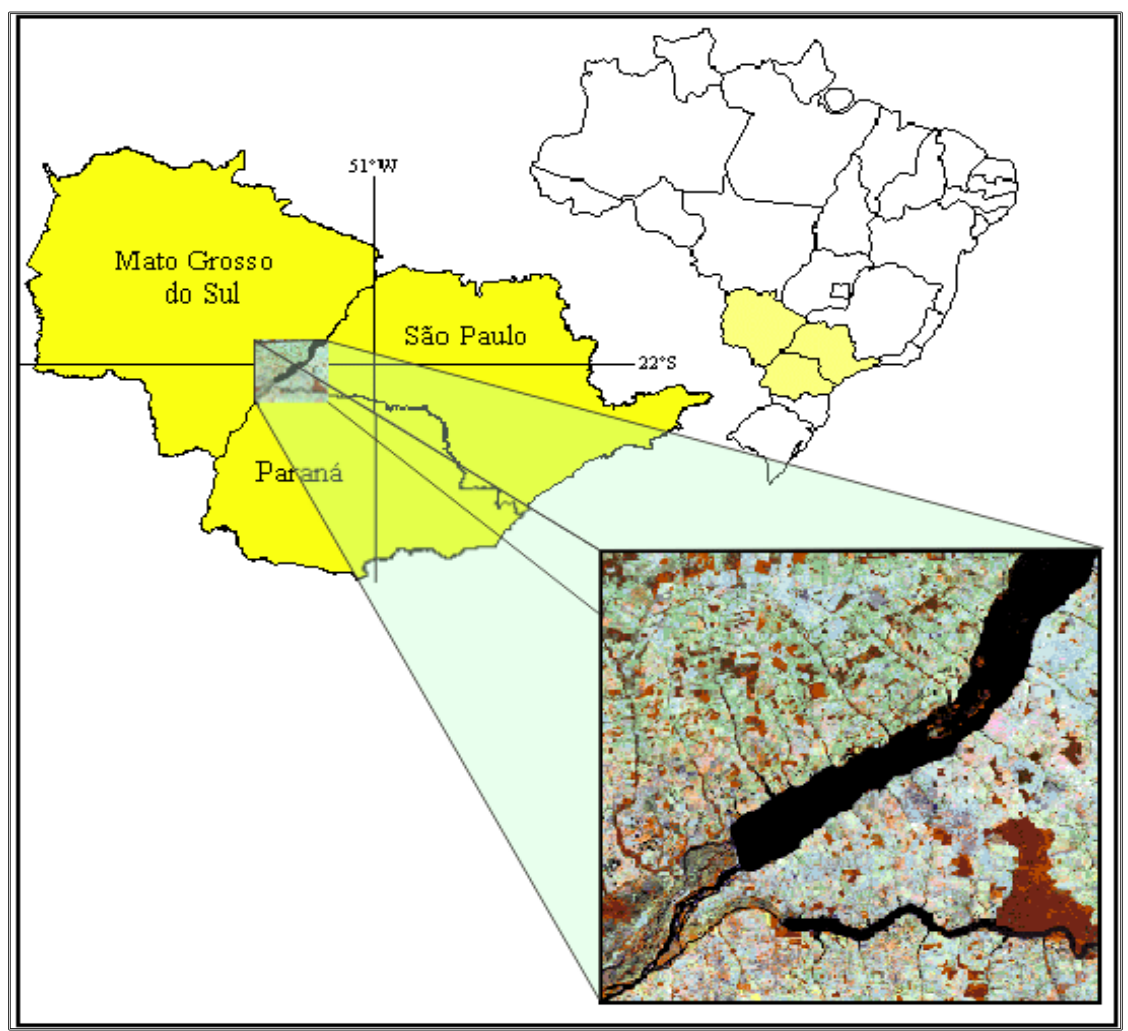

Figura 2: Localização da Raia Divisória São Paulo-Paraná-Mato Grosso do Sul. Fonte: DIAS (2003) 


\section{Conforme Torres:}

É bom lembrar que a devastação teve início com o surto cafeeiro que avançou para o interior do Estado, modificando a cobertura vegetal. Este avanço foi possível, também, devido a uma política internacional que favorecia tal economia. Assim, a intenção maior do desmatamento era a posse da terra e não a utilização da madeira enquanto recurso natural. (TORRES, 2003, p.67, grifo nosso)

Esta configuração no Sudoeste paulista se transformou quando a economia cafeeira entrou em declínio (período de crise econômica ${ }^{23}$ e guerras mundiais) e com a utilização das terras areníticas para a cultura do algodão e amendoim (principalmente no município de Mirante do Paranapanema) e a substituição da mata semidecídua por pastagens, após a década de 1940 no Pontal do Paranapanema. (PASSOS, 2007, p.17; p.297)

Os atores, ou "pioneiros e plantadores", geraram impactos ao meio ambiente na medida em que suas ações giravam em torno da idéia do desmatamento ${ }^{24}$ e das queimadas enquanto meio de garantia da posse da terra.

O território nesta porção da Raia Divisória foi ocupado sob uma concepção pouco adequada que conjuntamente à "incompetência e até a complacência dos governos em relação à destruição do meio ambiente natural" (LEITE, 1998, p.16), levou a um quadro geral de degradação ambiental fielmente representado pela paisagem nos dias atuais.

O Noroeste paranaense foi tardiamente ocupado no processo de expansão da economia cafeeira. Via de regra, a ocupação nesta área foi motivada pela própria expansão da cafeicultura paulista a partir do final da década de 1940, ou seja, num momento em que este tipo de atividade já dava amostras de seu declínio.

Um elemento importante a ser destacado quando se trata da colonização nesta região é o papel desempenhado pela Cia. Melhoramentos Norte do Paraná. Esta empresa levou a um modelo de divisão dos lotes voltado à pequena propriedade, cuja

\footnotetext{
${ }^{23}$ Crise econômica de 1929.

24 Desmatamento irregular sobre a Grande Reserva do Pontal definida pelo Governo Estadual no ano de 1941 com cerca de 284 mil hectares.
} 
produção tinha suas bases estabelecidas no café enquanto mercadoria principal, porém, com espaços para culturas associadas nas fases de formação dos cafezais ${ }^{25}$ como é o caso do feijão, milho, arroz, mandioca e a pecuária leiteira. (Cf. PASSOS, 2007, p.204)

Após a década de 1970, a economia regional passou por um relevante processo de reestruturação devido às novas imposições do mercado externo. Naquele momento o café perdeu o seu caráter de produção mais dinâmica no estado para outros produtos que anteriormente tinham reduzida importância no conjunto da economia agrícola (cultura de grãos: trigo e soja).

Os reflexos desta reestruturação se fizeram presentes na porção Noroeste paranaense, sobretudo com a expansão da pecuária em áreas onde as características naturais a isso levavam: "terras areníticas" com baixos índices de fertilidade, como é o caso da microrregião de Paranavaí.

Ao contrário do que aconteceu com o Norte e Oeste do Estado, o Noroeste não absorveu a agricultura de grãos devido à fragilidade de suas terras, o chamado Arenito Caiuá. O que restou da fase pioneira, sustentada na cafeicultura, foi um Noroeste esvaziado que se tornou ainda mais pobre com a gradual expansão das fazendas de gado e o fim, já na década de 1990, das lavouras de algodão que ocupavam grande número de trabalhadores. (PASSOS, 2007, p.226, grifo nosso)

A referida mudança dos parâmetros socioeconômicos, estabelecidos na região no transcorrer de sua colonização, levou a certa transformação de sua estrutura fundiária. Propriedades entre 10, 15 e 20 alqueires vivenciaram um processo de agregação resultando no aumento das unidades rurais, conforme as novas demandas do mercado, e no êxodo da população rural para as cidades da própria região ou para o Centro-Oeste do país.

Um importante fato a salientar, nesta breve exposição sobre os aspectos históricos e econômicos do Noroeste paranaense, é que apesar da região ter sido respaldada por um modelo econômico relativamente mais dinâmico - quando comparada ao Sudoeste paulista, por exemplo -, também apresentou/apresenta problemáticos impactos socioambientais: rápida derrubada da cobertura florestal;

${ }^{25}$ Com a plena produção dos cafezais estas culturas tornavam-se de subsistência. (PASSOS, 2007, P.204) 
depauperamento do solo por conta da intensa atividade agrícola no início de sua ocupação; empobrecimento do pequeno produtor diante das redefinições econômicas após a década de 1970; êxodo rural; drásticos exemplos de queda da população urbana em cidades cuja dinâmica econômica estava diretamente vinculada ao "mundo rural" (ver tabela 3, pg.82) etc.

Com relação à ocupação efetiva da porção Sudeste Sul mato-grossense (microrregião de Nova Andradina), podemos dizer que esta se deu de modo tardio quando comparada às outras regiões que compõem a Raia Divisória.

Passos (2007, p.277-278) menciona quatro frentes de expansão para a área, sobretudo a partir da década de $1970^{26}$ :

- Colonizadores paulistas que ocuparam a faixa que se estende de noroeste a sudoeste ao longo do Rio Paraná, adentrando na área pelos vales dos rios e ribeirões;

- Colonizadores paranaenses que entraram pelo vale do Rio Ivinhema, vindos de sul para o norte e penetrando para o interior do estado;

- A frente motivada pelos projetos no âmbito da "Marcha para o Oeste"27 da região de Deodápolis, Fátima do Sul, Glória de Dourados, entre outros, expandindo-se de oeste para leste.

- A frente de avanço criada pela facilidade de acesso devido às melhorias na BR267 (a partir da década de 1980), rodovia que liga o estado de São Paulo a Campo Grande, cortando a área no sentido leste-oeste.

O Sudeste Sul mato-grossense apresenta uma característica comum ao Sudoeste paulista e Noroeste paranaense: a presença de "terras areníticas". Não fosse a relativa

\footnotetext{
${ }^{26}$ Embora a região já conhecesse um processo de ocupação que remonta a períodos anteriores (a área de influência da Cia. Mate Laranjeira - de leste a oeste, estendendo-se ao sul do estado - desde o município de Porto Murtinho até Bataguassu, ainda no século XIX; o surgimento dos municípios de Bataiporã, Anaurilândia e Bataguassu nos anos 1950). Nesta parte do texto, optamos por abordar apenas as quatro mencionadas frentes de expansão porque foram, de fato, as responsáveis por uma alteração definitiva da paisagem regional.

27 Lembrando que a ocupação incentivada pela "Marcha para o Oeste", no âmbito do Governo de Getúlio Vargas, ocorreu a partir da década de 1940, não contemplando, por assim dizer, o Sudeste sul mato-grossense neste período. A ocupação mais marcante ocorreu na área correspondente à Colônia Agrícola Federal de Dourados (porção centro-sul do estado), onde o solo era mais propicio ao desenvolvimento da agricultura.
} 
diversificação da produção nesta última região ${ }^{28}$, poderíamos dizer que em todas elas há uma tendência à utilização para pecuária.

Tabela 3: Evolução da população de municípios da região Noroeste do Paraná

\begin{tabular}{|c|c|c|c|c|c|c|}
\hline Cidades & 1960 & 1970 & 1980 & 1991 & 1996 & 2000 \\
\hline Altônia & - & 43.042 & 42.777 & 24.589 & 20.187 & 19.224 \\
\hline Alto Piquiri & - & 40.439 & 22.269 & 17.229 & 11.595 & 10.760 \\
\hline Cruzeiro do Sul & 10.159 & 8.088 & 5.710 & 5.006 & 4.697 & 4.776 \\
\hline Inajá & - & 4.380 & 2.685 & 2.642 & 2.725 & 2.913 \\
\hline Iporã & - & 72.115 & 37.567 & 26.032 & 17.336 & 16.444 \\
\hline Itaguajé & 17.735 & 8.563 & 5.224 & 5.054 & 4.514 & 4.768 \\
\hline Jardim Olinda & - & 2.419 & 1.305 & 1.405 & 1.342 & 1.524 \\
\hline Nova Esperança & 43.095 & 29.379 & 23.943 & 24.189 & 25.877 & 25.713 \\
\hline Paranacity & 23.729 & 11.642 & 8.321 & 8.528 & 9.410 & 9.106 \\
\hline Paranapoema & - & 4.044 & 2.160 & 2.455 & 2.478 & 2.387 \\
\hline
\end{tabular}

Os dados do período (IBGE) são representativos de um verdadeiro esvaziamento populacional na região em questão após a década de 1970. Adaptado de: Passos (2007, p.226)

Por outro lado, existem semelhanças paisagísticas entre as porções paulista e sul mato-grossense não apenas no que diz respeito ao tipo de solo, mas principalmente pela configuração e destinação da própria estrutura fundiária, isto é, a presença de grandes propriedades com pastagens que denotam relativa homogeneidade fisionômica da paisagem entre as duas parcelas territoriais.

Estas semelhanças, por sua vez, nos levam a pensar na influência das frentes de expansão sobre a região a partir da década de 1970, uma vez que grande número de

\footnotetext{
${ }^{28}$ É importante frisar que a presença das "terras areníticas" não é absoluta para todo o Noroeste paranaense, onde também aparecem manchas de terra roxa (sobretudo na porção leste da região) que, do ponto de vista da fertilidade natural, são muito mais adequadas para a produção agrícola. Certamente este também é um fator que contribuiu/contribui para a relativa diversificação da agricultura nesta região.
} 
paulistas esteve envolvido naqueles fluxos ${ }^{29}$. De imediato, apontamos para a fragilidade econômica tanto na escala local (municípios) quanto na escala regional (microrregião de Nova Andradina) vinculada à tendência dos proprietários rurais investirem seus lucros em outras áreas.

Pelo caráter tardio da ocupação na região, pode-se dizer que a construção da paisagem no Sudeste Sul mato-grossense é muito recente quando analisada sob o ponto de vista da ação antrópica sobre seu potencial geoecológico. Acrescente-se a isto, a rápida aceleração no ritmo da construção paisagística com a entrada de um novo agente que exerceu importante papel no incentivo à geração de novas dinâmicas regionais: a CESP (após a década de 1980), de modo que:

A UHE de Porto Primavera trouxe uma aceleração na escala temporal dos acontecimentos regionais, sobretudo no que diz respeito ao processo de construção da paisagem [...].

Obviamente, diversos outros eventos importantes coincidiram com a implantação da UHE e contribuíram para a construção da paisagem regional e, em determinados casos, muito mais do que esta. Mas a UHE enquanto promovedora de uma ruptura no ritmo de evolução socioeconômica e ambiental vigentes, desponta-se, globalmente, como o evento mais relevante do processo direta ou indiretamente. Em se tratando de uma UHE das proporções de Porto Primavera, os efeitos/impactos tendem a ser deveras significativos, mesmo que esta tenha sido implantada numa região deprimida do ponto de vista socioeconômico. (DIAS, 2003, p.135, grifo nosso)

A respeito dos efeitos/impactos de grande magnitude, podemos citar a própria formação do lago da usina que possui cerca de $2.250 \mathrm{Km}^{2}$ de área, sendo que sua maior parte está localizada no estado de Mato Grosso do Sul ( $80 \%$ da área). Portanto, um empreendimento com sérios agravantes ao meio ambiente e às populações locais, fato este que trouxe a necessidade, por parte da CESP, em programar uma série de obras compensatórias e mitigatórias (construção de estradas, investimentos em infra-estrutura urbana nos municípios atingidos, projetos de assentamento ou reassentamento para as

\footnotetext{
${ }^{29}$ Fato este responsável pela propriedade de significativa parte das terras no município de Anaurilândia estar em mãos de fazendeiros paulistas, por exemplo. Passos (2007, p.284) apresenta dados interessantes a respeito: no ano de 2002 o número de proprietários rurais de origem sul mato-grossense no município era de 274 contra 208 de origem paulista, 32 de origem paranaense, 4 de origem mineira e 1 de origem carioca. Os proprietários sul mato-grossenses detinham 53\% da área rural do município; os paulistas, 40\%; paranaenses, $6 \%$; mineiros, $0,8 \%$ e carioca, $0,2 \%$.
} 
populações atingidas no processo de enchimento do lago da usina etc.) para compensar os prejuízos.

Desta forma, embora o estado do Mato Grosso do Sul tenha sido o mais atingido em termos de impacto socioambiental, a presença de uma obra desta magnitude gerou intensas transformações socioeconômicas na Raia Divisória como um todo: no Noroeste paranaense de modo menos direto em comparação ao Pontal do Paranapanema.

Obstamo-nos nesta rápida caracterização de cada uma das parcelas territoriais (paulista, paranaense e sul mato-grossense) porque a compreensão de sua processualidade histórica nos leva ao entendimento mais amplo da própria dinâmica socioambiental atual na Raia Divisória como um todo. Para melhor visualização de tudo o que foi exposto até este momento do texto, elaboramos um quadro-síntese da formação territorial da/na Raia: quadro 2 (pg.85).

Neste quadro frisamos a presença dos elementos geoecológicos comuns às três parcelas da Raia (as formações do Grupo Bauru ${ }^{30}$ ) porque de forma direta esta característica teve influência na definição das atividades agropecuárias (predominância de solos areníticos) que configuraram a economia regional desde os primeiros momentos da ocupação/colonização, merecendo especial atenção principalmente nas fases de redefinições das dinâmicas de apropriação do território pelas sucessivas sociedades.

Nas parcelas territoriais da Raia Divisória, a presença do arenito da Formação Caiuá é muito significativa (embora não seja absoluta) e ele é:

[...] caracterizado por uma alta permeabilidade, pela produção de solos de baixa fertilidade natural e de alto índice de erosividade, o que vai ter um papel fundamental nas paisagens produzidas, em especial pela limitação que este impõe a certos tipos de ocupação e uso do solo. (DIAS, 2003, p.13, grifo nosso)

Assim, podemos dizer que tanto no Sudoeste paulista quanto no Noroeste Paranaense e Sudeste Sul mato-grossense, a limitação imposta pelos solos areníticos fez com que a implantação das pastagens fosse adotada, muitas vezes, em detrimento da

\footnotetext{
${ }^{30}$ No caso da Raia SP-PR-MS: Formações Caiuá, Santo Anastácio e Adamantina. (Cf. DIAS, 2003, p.12)
} 
agricultura principalmente depois das redefinições econômicas observadas entre as décadas de 1950 e 1970.

Quadro 2: Formação Territorial da Raia Divisória

\begin{tabular}{|c|c|c|c|}
\hline \multicolumn{4}{|c|}{ Síntese da Formação Territorial da Raia Divisória SP-PR-MS } \\
\hline \multirow{2}{*}{ Parcelas } & Sudoeste Paulista & Noroeste Paranaense & $\begin{array}{l}\text { Sudeste Sul mato- } \\
\text { grossense }\end{array}$ \\
\hline & Pontal do Paranapanema & $\begin{array}{l}\text { Microrregião de } \\
\text { Paranavaí }\end{array}$ & $\begin{array}{c}\text { Microrregião de Nova } \\
\text { Andradina }\end{array}$ \\
\hline $\begin{array}{l}\text { Elemento da } \\
\text { estrutura } \\
\text { geoecológica em } \\
\text { comum }\end{array}$ & Arenitos do Grupo Bauru & $\frac{\text { Arenitos do Grupo }}{\text { Bauru }}$ & $\frac{\text { Arenitos do Grupo }}{\text { Bauru }}$ \\
\hline Ocupação & $\begin{array}{l}\text { Primeiras décadas do séc. XX } \\
\text { (Colonização mais "aleatória" } \\
\text { onde o desmatamento foi } \\
\text { adotado como meio de se } \\
\text { garantir a posse da terra) }\end{array}$ & $\begin{array}{l}\text { Sobretudo após a } \\
\text { década de } 1940 \\
\text { (Colonização baseada } \\
\text { nos moldes da Cia. } \\
\text { Melhoramentos Norte } \\
\text { do Paraná visando } \\
\text { maior dinamismo } \\
\text { econômico) }\end{array}$ & $\begin{array}{l}\text { Criação de municípios } \\
\text { na década de 1950; } \\
\text { Novas frentes de } \\
\text { ocupação definitivas na } \\
\text { década de } 1970 \\
\text { (Colonização com } \\
\text { predomínio de grandes } \\
\text { propriedades rurais) }\end{array}$ \\
\hline Motivações & Binômio cafeicultura-ferrovia & $\begin{array}{c}\text { Expansão da } \\
\text { cafeicultura paulista }\end{array}$ & Pastagens naturais \\
\hline Redefinições & $\begin{array}{c}\text { 1940-1960: produção agrícola } \\
\text { (algodão/amendoim); } \\
\text { Empresas beneficiadoras de } \\
\text { algodão; } \\
\text { Após 1980: Alteração das } \\
\text { dinâmicas regionais com a } \\
\text { chegada da CESP; } \\
\text { Destilaria Alcídia; } \\
\text { Assentamentos rurais de } \\
\text { reforma agrária. }\end{array}$ & $\begin{array}{c}\text { 1950-1970: declínio da } \\
\text { cafeicultura e avanço } \\
\text { da produção pecuária; } \\
\text { Após 1980: } \\
\text { diversificação da } \\
\text { economia rural; } \\
\text { Agroindústrias; } \\
\text { Impactos indiretos nas } \\
\text { dinâmicas regionais } \\
\text { com a chegada da } \\
\text { CESP; }\end{array}$ & $\begin{array}{c}\text { 1950-1980: Pastagens } \\
\text { artificiais; } \\
\text { Após 1980: Alteração } \\
\text { das dinâmicas regionais } \\
\text { com a chegada da } \\
\text { CESP; } \\
\text { Assentamentos rurais } \\
\text { de reforma agrária; } \\
\text { Assentamentos (ou } \\
\text { reassentamentos) } \\
\text { implantados pela CESP. }\end{array}$ \\
\hline
\end{tabular}

Org.: SOUZA, Reginaldo J.; Fonte: PASSOS (2007); DIAS (2003); LEITE (1998).

Traçamos alguns exemplos de tais redefinições quando citamos, no quadrosíntese da formação territorial da Raia Divisória, fatos como a chegada de empresas beneficiadoras de algodão no Pontal do Paranapanema (no município de Mirante do Paranapanema, especificamente), o avanço da pecuária para áreas de solos areníticos no 
Noroeste do Paraná ou a introdução das pastagens de caráter artificial no Sudeste Sul mato-grossense.

A respeito das atividades agrícolas voltadas à cultura do algodão no Pontal do Paranapanema, é importante destacar que estas impulsionaram uma morfodinâmica muito agressiva, resultando em um rápido exaurimento do solo com geração de erosões e assoreamento dos córregos, sobretudo no município de Mirante do Paranapanema que se destacou nos anos de 1950 com este tipo de atividade. Porém, após o declínio da produção algodoeira as pastagens se tornaram elementos marcantes da paisagem local/regional porque o solo, que já era frágil, tornou-se ainda menos capaz de suportar uma agricultura em moldes mais intensivos.

“Ao sul do Pontal, já no estado do Paraná, a mancha de solos-caiuá ${ }^{31}$ permanece, apresentando-se ainda mais frágil como o atestam as enormes voçorocas de Cianorte, Paranaciti e Paranavaí [...]". (LEITE, 1998, p.20) Nestas áreas, a pecuária foi empregada, sobretudo entre fins dos anos 1970 e início de 1980, quando se atestou uma rápida redução do cultivo de café. Este fato, aliado à nova conjuntura do mercado externo ${ }^{32} \mathrm{e}$ à baixa fertilidade do solo na região formou a equação perfeita que resultaria na adoção da pecuária como atividade mais rentável, malgrado a redução da mão-de-obra no setor e conseqüente onda de êxodo rural para as próprias cidades do Paraná ou para outras regiões do país à época.

A permanência da pecuária na porção Sudeste Sul mato-grossense limitou ou inibiu a atração de outras atividades econômicas desde os primeiros momentos da ocupação efetiva do território. Os moldes de colonização estabelecidos e a mentalidade dos agentes construtores da paisagem (mormente proprietários de terras) se juntaram

\footnotetext{
310 autor (LEITE, 1998) certamente faz referência ao Latossolo Vermelho-Escuro em áreas de arenito da Formação Caiuá na região mencionada.

32 Kohlhepp (1991) citado por Passos (2007, p.227) faz menção a esta nova conjuntura do mercado externo (e sua influência sobre as atividades agropecuárias no Noroeste paranaense) nos seguintes termos: “A rápida redução da área de cultivo de café entre os fins dos anos 70 e princípios dos anos 80, é, em última análise, uma conseqüência da alta conjuntura das alternativas cash-crop, como por exemplo, a soja, ou a rotação trigosoja, no âmbito da modernização da agropecuária, assim como do desenvolvimento positivo dos preços da carne em combinação com a minimização dos custos de mão-de-obra na pecuária. Este último fator levou, especialmente no noroeste ao emprego definitivo para a pecuária das terras arenosas "Caiuá" pobres em minerais.
} 
às propriedades físico-químicas dos solos e, de certa forma, impuseram uma vocação pastoril à região.

É importante deixar claro que não estamos aqui conferindo qualquer justificativa determinista aos diferentes graus de dinamismo econômico (ou ausência de) existentes nas três parcelas que compõem a Raia Divisória SP-PR-MS. Obviamente, as propriedades do tipo de solo em evidência não podem ser tomadas, em si, como único fator responsável pelas decisões quanto à escolha pela implantação de pastagens ou da agricultura. Mas de acordo com o levantamento bibliográfico que fizemos e as prospecções de campo, evidenciamos o grau de importância que a relação tipo/uso do solo assumiu na caracterização histórica destas áreas em termos de construção da paisagem.

Em tempos mais recentes, um dado muito interessante é ilustrativo de uma possível superação de certas dificuldades impostas pela baixa fertilidade dos solos: o Projeto Arenito Nova Fronteira ${ }^{33}$ que visa dinamizar a produção agrícola diversificada e não unicamente voltada para a pecuária - nas terras areníticas do Noroeste paranaense.

O projeto entrou em vigor na região no ano de 1997, por iniciativa da Cooperativa de Cafeicultores e Pecuaristas de Maringá (Cocamar) e apoio do Instituto Agronômico do Paraná (IAPAR), da empresa multinacional Syngenta, da Universidade Estadual de Maringá (UEM) e das Prefeituras Municipais por meio de fornecimento de recursos técnicos, profissionais e financeiros. O objetivo desta parceria é a recuperação dos solos, extremamente desgastados, por meio da agricultura conduzida com tecnologia de ponta em que:

[...] áreas de pastagens são mecanizadas e durante períodos que variam de três a cinco anos, são cobertas por lavouras de soja, voltando depois, já com a terra recuperada do ponto de vista químico e biológico, a ser utilizada como pastagem, caso este seja o interesse do proprietário da área. (FONSECA et. al., 2005, grifo nosso)

\footnotetext{
33 Para maiores detalhes, consultar o endereço eletrônico:

<http://www.cocamar.com.br/Portal/cooperado/arenito.html>
} 
Passos (2007, p.240) aponta para a expansão da agricultura de grãos na referida região como uma conseqüência da geração de rápidos retornos (em termos de produtividade) em poucos meses após o plantio e se refere a uma possível dinamização dos fluxos na Raia Divisória SP-PR-MS a partir de:

- Ações no âmbito do Projeto Arenito Nova Fronteira na porção paranaense, de modo que o Sudoeste paulista e Sudeste Sul mato-grossense sejam "influenciados" pela diversificação da produção agrícola existente naquele estado;

- Criação de infra-estrutura por meio das obras compensatórias e mitigatórias realizadas pela CESP (barragens, pontes, estradas asfaltadas etc.), tanto na porção paulista quanto na sul mato-grossense;

- Ações de agentes locais-regionais, tais como as Prefeituras Municipais e agroindústrias (laranja, mandioca, frango etc., sobretudo no noroeste paranaense).

Enfim, todos estes elementos são visualizados pelo referido autor como possibilidades abertas aos atores sociais, envolvidos na produção/reprodução do território, em promover uma verdadeira integração socioeconômica entre as três parcelas que compõem a Raia como um todo, alterando o atual estado de baixa fluidez e opacidade $^{34}$ em que ela se encontra. (PASSOS, 2007, p.298)

\section{5) Algumas considerações}

Iniciamos este capítulo com uma discussão sobre o significado do conceito de fronteira no intuito de explicitar elementos que justificassem nossa opção pelo uso do termo raia ao tratarmos do conjunto regional/territorial composto pelo Sudoeste paulista, Noroeste paranaense e Sudeste Sul mato-grossense.

Inicialmente chegamos à conclusão de que não existem diferenças entre os termos raia e fronteira. É de comum acordo que a "tradução" deste último no debate geográfico vai ao encontro de sua polissemia e complexidade.

${ }^{34}$ Termos emprestados de Santos, M. e Silveira, M. L.: O Brasil. Território e Sociedade no início do século XXI; capítulo XII - As diferenciações do território, p.259. (nota do autor) 
Fronteiras não são meros limites, marcos, barreiras ou divisas entre municípios, estados ou países. Embora o limite - enquanto abstração - esteja contido na definição de fronteira, ele não a sintetiza porque a análise das fronteiras implica em enfoques abrangentes que transitam entre diferentes variáveis, sejam elas:

- a (des)organização da sociedade em suas várias dimensões (economia, política, cultura);

- a apropriação dos elementos naturais e os impactos humanos no meio ambiente durante o processo de produção/reprodução de territórios;

- as descontinuidades paisagísticas evidenciadas em áreas fronteiriças e que são expoentes de diferentes configurações territoriais;

- os diferentes níveis dos fluxos (pessoas, mercadorias, informações), enfim, das permeabilidades nas zonas de contato inter-territoriais etc.

Raia é, neste sentido, um sinônimo de fronteira. Porém a utilização do termo na Geografia brasileira não é algo muito comum. Aderimos este termo para apresentar o recorte regional/territorial na zona de contato entre os estados de São Paulo, Paraná e Mato Grosso do Sul porque quando nos voltamos ao contexto de sua abordagem mais freqüente - fronteira/raia luso-espanhola, por exemplo - fica evidente que sua utilização está diretamente voltada à elaboração de políticas públicas para o desenvolvimento de regiões deprimidas entre Portugal e Espanha.

Neste sentido, apresentamos os exemplos de raias no Brasil, traçados por Passos (2006), que reclamam por projetos que viabilizem um verdadeiro desenvolvimento local/regional.

A Raia Divisória SP-PR-MS também se inclui no rol de regiões onde se verifica baixa fluidez e opacidade socioeconômica resultantes de relativa ausência de projetos que promovam maior integração entre os territórios que a compõe.

Por vários momentos nos questionamos sobre a pertinência em se trabalhar com a composição: raia + divisória. Não seria isto uma contradição à própria definição do conceito de fronteira e conseqüentemente de raia, enquanto seu sinônimo, conforme apresentamos no início do texto? Se fronteiras ou raias pressupõem espaços de 
interpenetrações de geografias, como poderíamos, então, falar de uma raia divisória? Seriam termos excludentes um ao outro?

Diante destas questões, a melhor postura a ser tomada é a da imprecisão. Parafraseando Hissa (1998, p.54): uma imprecisão onde "o vago passa a ser o exato (e sobretudo o fecundo), numa aparente contradição".

No caso específico da Raia Divisória SP-PR-MS é possível apreender claramente os reflexos das permeabilidades entre suas três parcelas territoriais, principalmente quando nos remetemos aos processos de colonização.

No passado, a produção cafeeira adentrou no Noroeste paranaense a partir do estado de São Paulo. Fazendeiros paulistas adquiriram grandes porções de terra no Sudeste Sul mato-grossense cujo tipo de atividade estabelecida na área levou à relativa homogeneidade paisagística entre o Pontal do Paranapanema e a microrregião de Nova Andradina.

Mais recentemente, a chegada da CESP alterou a configuração da paisagem regional por meio das obras compensatórias e mitigatórias. Trouxe algumas melhorias por um lado (construção de pontes e asfaltamento de estradas, investimentos em infraestrutura urbana, projetos de assentamentos etc.), mas por outro gerou significativos impactos socioambientais, principalmente no Mato Grosso do Sul.

Atualmente, em todos os dias da semana nas épocas de colheita de cana-deaçúcar, basta chegar às margens do rio Paranapanema ao fim das tardes para se ver no porto de Euclides da Cunha Paulista-SP uma significativa quantidade de trabalhadores bóias-frias que embarcam na balsa rumo à Terra Rica-PR, de volta para suas casas. Alguns homens e mulheres tomam banho nas águas do rio Paranapanema enquanto a balsa ainda está atracada. Outros tomam alguma bebida em uma pequena barraca. Ali aproveitam para tirar a sujeira do corpo ou para relaxar com uma dose de bebida alcoólica, mas é do lado de lá que querem chegar para descansar e no outro dia retornar e retomar a jornada...

Ou seja, de alguma forma existe uma interpenetração de fluxos entre as parcelas territoriais que define/enquadra a Raia naquela concepção de "zona de contato". A 
Raia é permeável, mas ao mesmo tempo é divisória. Isto porque ainda não existem projetos que visem sua integração, dinamização e seu desenvolvimento como um todo.

\section{$\operatorname{sos} 2$}

Neste capítulo abordamos alguns elementos sobre a temática da fronteira no âmbito da Geografia e as principais características das parcelas territoriais que compõem a Raia Divisória SP-PR-MS. Após apresentarmos o panorama da Raia, trataremos especificamente das dinâmicas socioambientais em Mirante do Paranapanema. 


\section{Capítulo IV: \\ As dinâmicas}

socioambientais em

Mirante do Paranapanema 


\section{soci}

“... Homens labutando, ansiosos pra vencer

Cavando a terra 6ruta empregando o seu saber

A mata que existia em braços fortes pereceu

$\mathcal{E}$ da noite para o dia uma cidade floresceu.

Mirante, salve Mirante

Tu és orgulho desse povo triunfante".

(Trecho do hino a Mirante do Paranapanema - José

Elias Kershaw)

8003 


\section{1) Notas introdutórias}

Podemos afirmar que a natureza antropizada não é mais o que ela era no passado remoto. Os impactos humanos sobre sua estrutura e funcionamento, dia após dia, nos remetem a diversos desafios. Um deles está na busca por teorias e métodos científicos capazes de abarcar a problemática ambiental e fornecer respostas criativas às necessidades de usos mais racionais dos recursos naturais.

Por longo tempo a natureza passou apagada pela história dos homens, servindo apenas como fornecedora de matérias-primas para a produção de mercadorias, sobretudo após o estabelecimento do capitalismo industrial. Atualmente ela retorna ao debate entre todos aqueles que se interessam pela atual desordem do mundo e se preocupam com o futuro (imediato ou de longo prazo) do planeta.

Para nós geógrafos, a atenção sobre a problemática ambiental é praticamente uma tradição desde a institucionalização de nossa ciência. Hoje em dia, quando estudamos a história do pensamento geográfico e suas implicações nas produções científicas, entendemos que nem sempre as teorias e métodos utilizados no passado (e até mesmo no presente) foram/são suficientes para uma abordagem mais substanciosa da questão socioambiental. Porém, a tradição geográfica em transitar entre as franjas dos fatos sociais e dos naturais é inegável.

A partir destes pressupostos, realizamos a análise sobre as dinâmicas socioambientais em nossa área de estudos. Tendo o embasamento bertrandiano em vista, saímos a campo, buscamos informações nos órgãos públicos (Prefeitura Municipal, Promotoria do Meio Ambiente, ITESP) e realizamos entrevistas semidirigidas junto aos moradores de Mirante do Paranapanema - da bacia do ribeirão Santo Antônio, especificamente - com o intuito de melhor compreender toda a processualidade que levou/leva à atual configuração paisagística deste município.

Neste capítulo apresentaremos nossas reflexões sobre as dinâmicas socioambientais neste território, tomando a paisagem como ponto de partida... 


\section{2) Perpassando por breves elementos históricos}

No Pontal do Paranapanema, com a chegada dos colonizadores e avanço da fronteira agrícola, a fauna e a flora foram substancialmente alteradas e tanto o potencial ecológico como a população regional foram prejudicados. Em linhas gerais, o início do processo de derivação das paisagens nesta área ocorreu conforme os acontecimentos que explicitaremos a seguir.

Entre os anos de 1917 a 1922, a Estrada de Ferro Sorocabana avançou de Presidente Prudente até Presidente Epitácio, possibilitando a expansão do cultivo de café para o oeste paulista, porém, ainda não atingindo a área correspondente ao Pontal do Paranapanema.

Somente no início da década de 1940 as matas do atual município de Mirante do Paranapanema começaram a ser eliminadas, abrindo espaço para a cultura do algodão. Durante a década de 1950 a devastação das reservas estaduais do município de Teodoro Sampaio foi incrementada. Entre 1955 e 1965 as reservas estaduais, na região, passaram pela fase mais crítica.

No Pontal do Paranapanema, a partir deste momento histórico, manifestaram-se os impactos socioambientais negativos - pela eliminação das reservas - e um quadro de injustiça social muito grave - pela instalação dos latifúndios e da pecuária, com expulsão daqueles que anteriormente tinham sua mão-de-obra explorada nas fazendas.

A partir de 1976, em um quadro de crise econômica, novos projetos compareceram com certas propostas de desenvolvimento regional para o Pontal do Paranapanema: a Destilaria de Álcool Alcídia S/A, as hidroelétricas da CESP e os reassentamentos dos pequenos proprietários desalojados pelas suas obras, além do "Projeto de Valorização Agrícola do Pontal" e reforma agrária implantada na Gleba XV de Novembro (município de Rosana) na década de 1980.

De uma forma geral, a crise energética e agrária criou um clima de maior tolerância em relação aos "depredadores" das áreas de mata do Pontal do Paranapanema, que passaram a ser visualizadas, por muitos, como áreas disponíveis para projetos agrícolas e hidroelétricos. 
Dentro do conjunto da paisagem originalmente uniforme do Pontal do Paranapanema, as ações antrópicas atuaram diversamente, criando um mosaico paisagístico passível de análise a partir de vários critérios: das singularidades paisagísticas diretamente observáveis no território até o critério de uso do solo, por exemplo.

No que diz respeito, especificamente, a Mirante do Paranapanema, este foi palco de um tipo de ocupação agrícola - desde momentos anteriores à sua emancipação político-administrativa (ano de 1953) - que provocou uma morfodinâmica muito agressiva, resultando em um rápido exaurimento do solo, com erosão e assoreamento dos córregos, ou seja, consubstanciando-se uma série de impactos ambientais que, de modo direto ou indireto, acabaram por se refletir na sociedade local até os dias atuais.

A utilização agrícola mais marcante no município ocorreu principalmente durante as décadas de 1950 e 1960 tendo o algodão como carro-chefe da produção. A cotonicultura em Mirante do Paranapanema foi estimulada com a chegada das empresas beneficiadoras (SANBRA e Braswey, por exemplo).

Certamente podemos afirmar que as práticas agrícolas daquele período também se incluiriam no rol de fatores que gerariam agudas dificuldades em se manter lavouras plenamente produtivas no município atualmente. Tudo isso porque a relativamente intensa produção de algodão contribuiu para o esgotamento do solo.

Este acontecimento se refletiu na economia e no quadro socioambiental local, dando margem à expansão das áreas de pastagens, principalmente depois dos anos de 1970 e 1980. A seguir apresentaremos três figuras (3, 4 e 5) representativas de diferentes categorias de uso do solo em Mirante do Paranapanema nos anos de 1985, 1995 e 2005 respectivamente. 


\begin{tabular}{|c|c|c|c|c|c|c|c|c|c|c|}
\hline 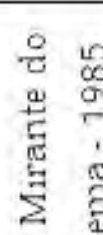 & $\frac{\pi}{Z}$ & $\frac{\sum_{\pi}^{\pi}}{2}$ & 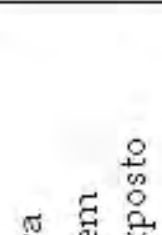 & 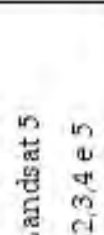 & $\sum_{\frac{\pi}{\pi}}^{\pi}$ & $\begin{array}{l}\text { ह } \\
\text { ี. }\end{array}$ & 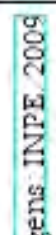 & 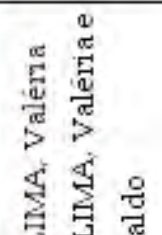 & 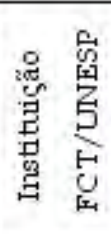 & 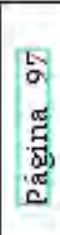 \\
\hline 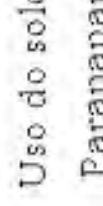 & 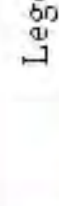 & 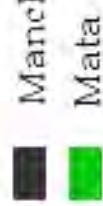 & 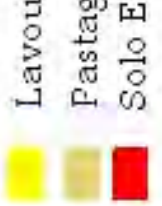 & 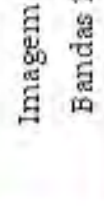 & 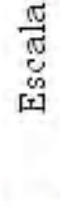 & in & 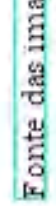 & 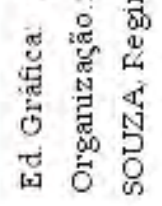 & 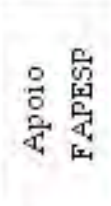 & 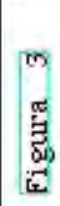 \\
\hline
\end{tabular}
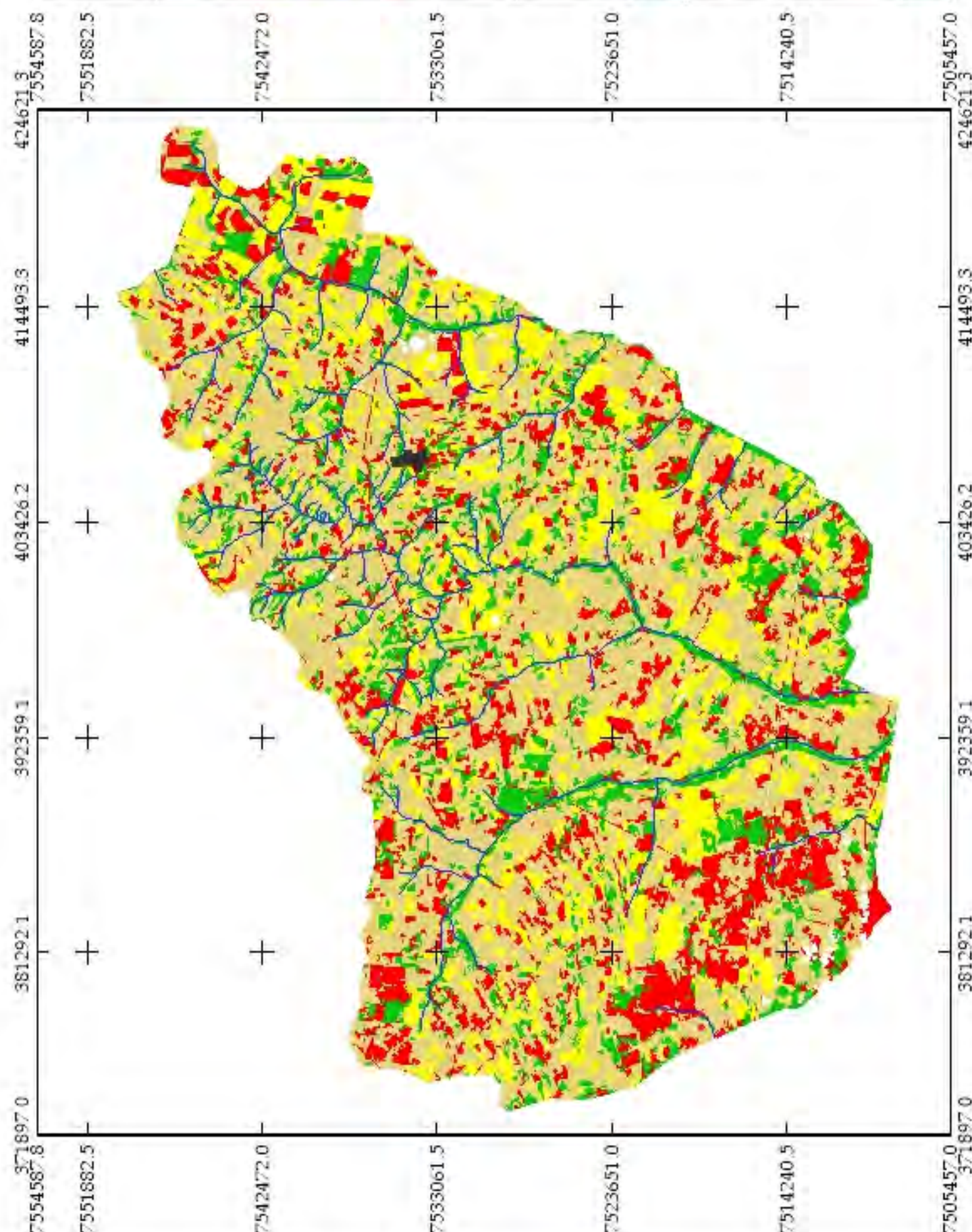


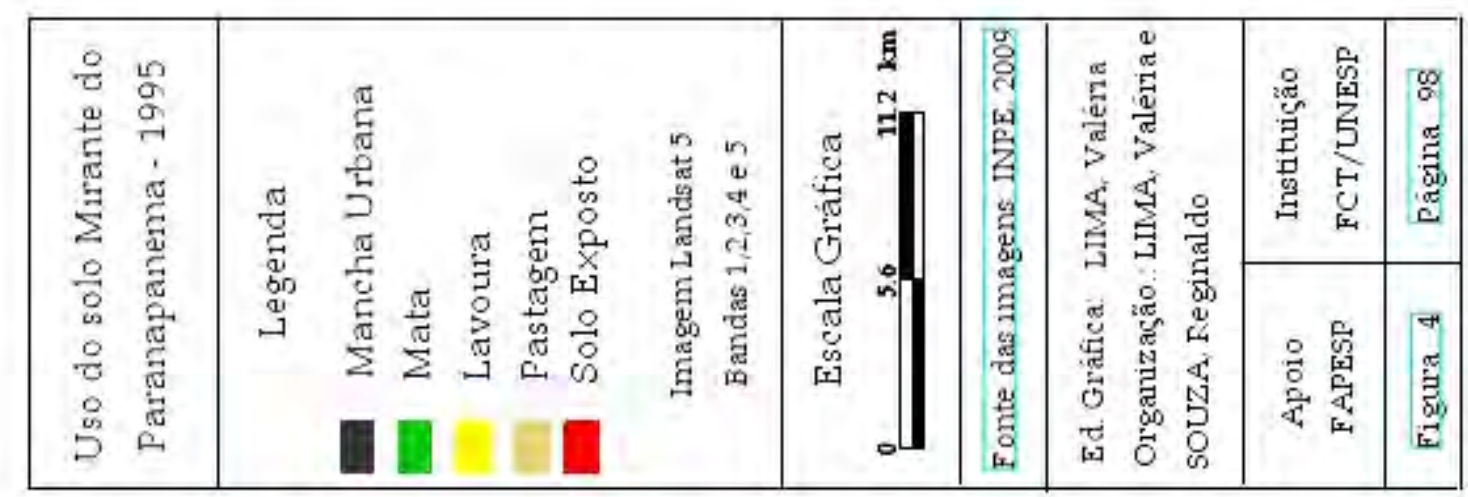
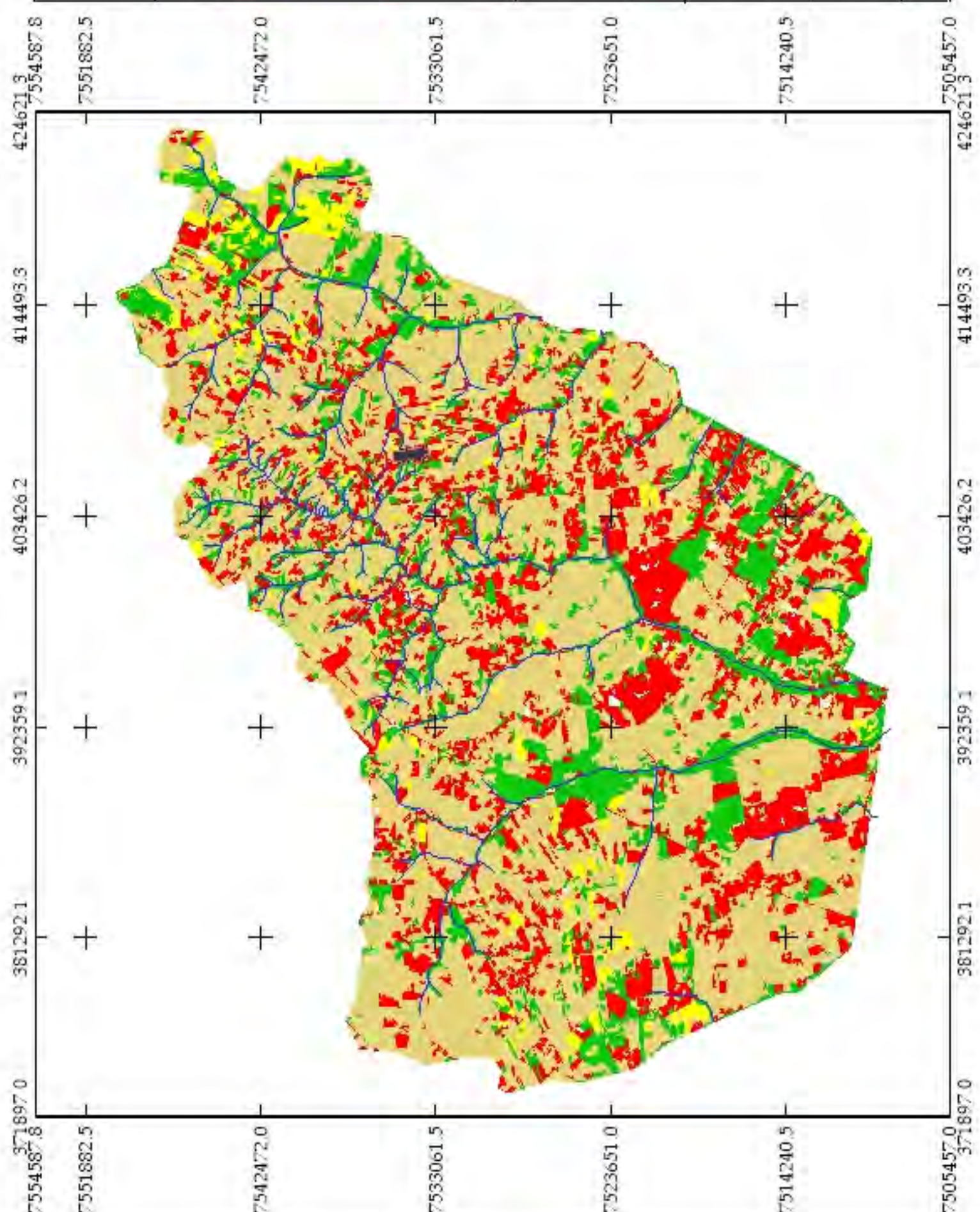


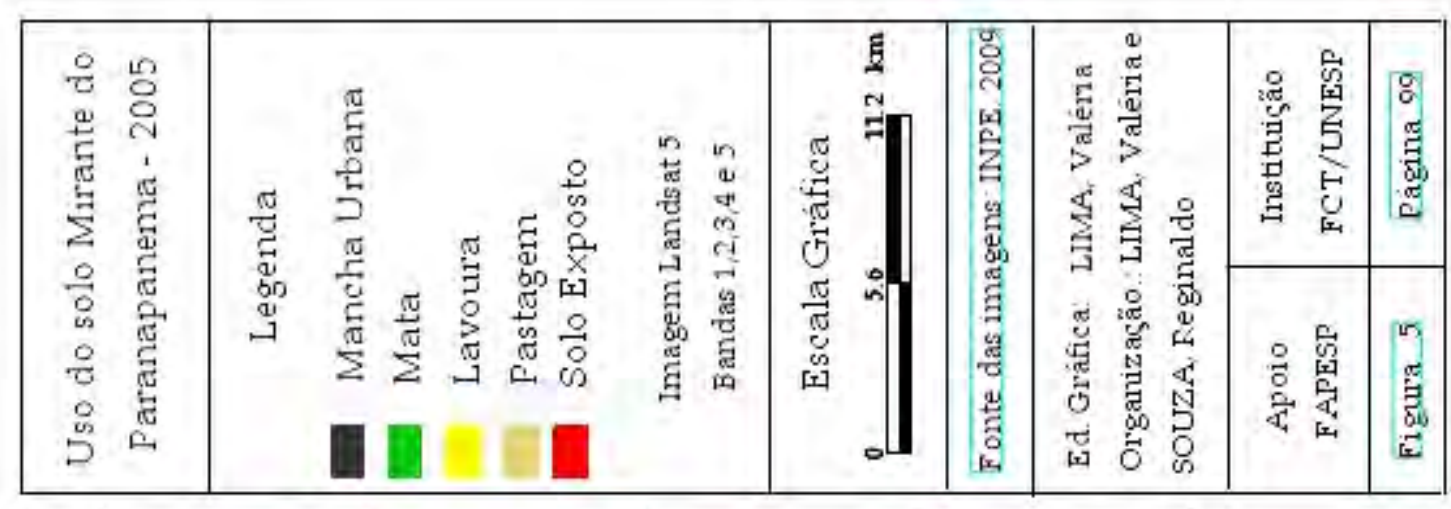
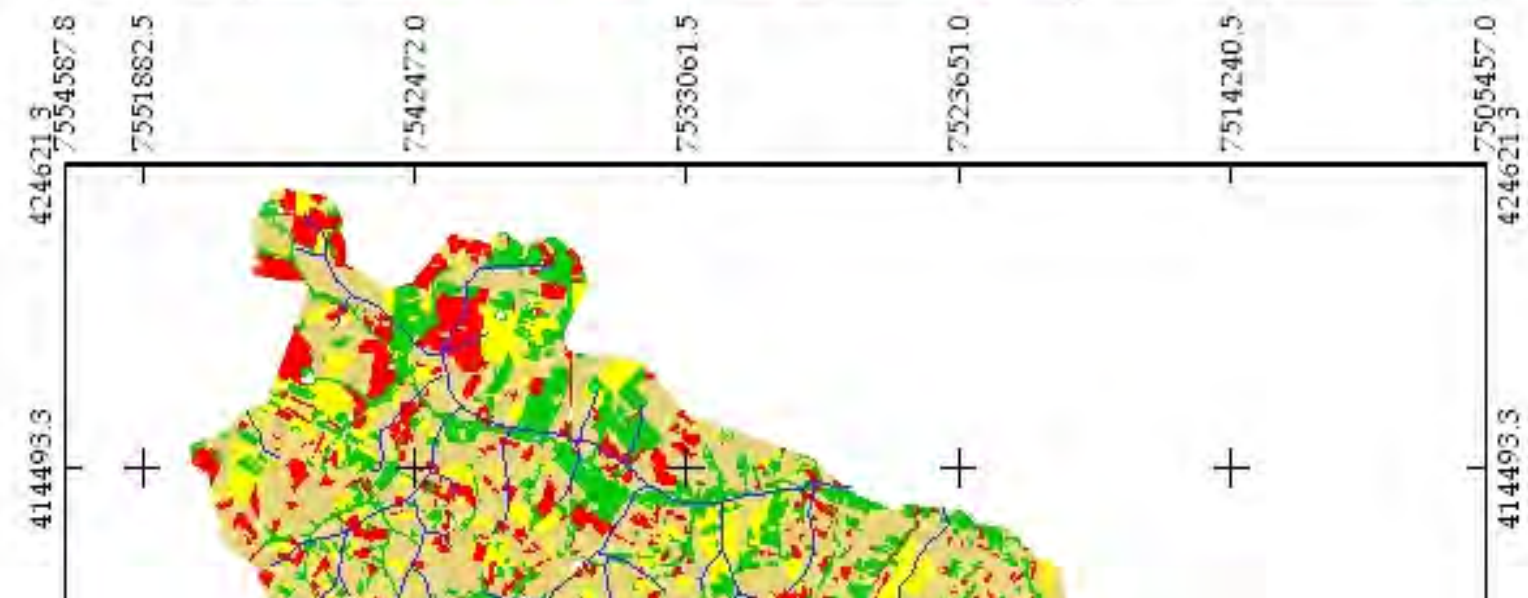

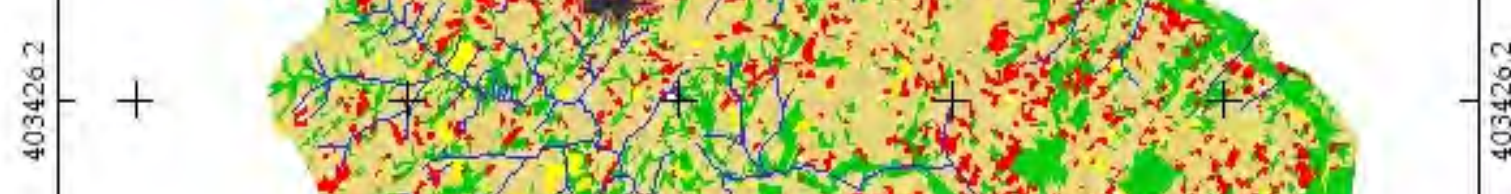

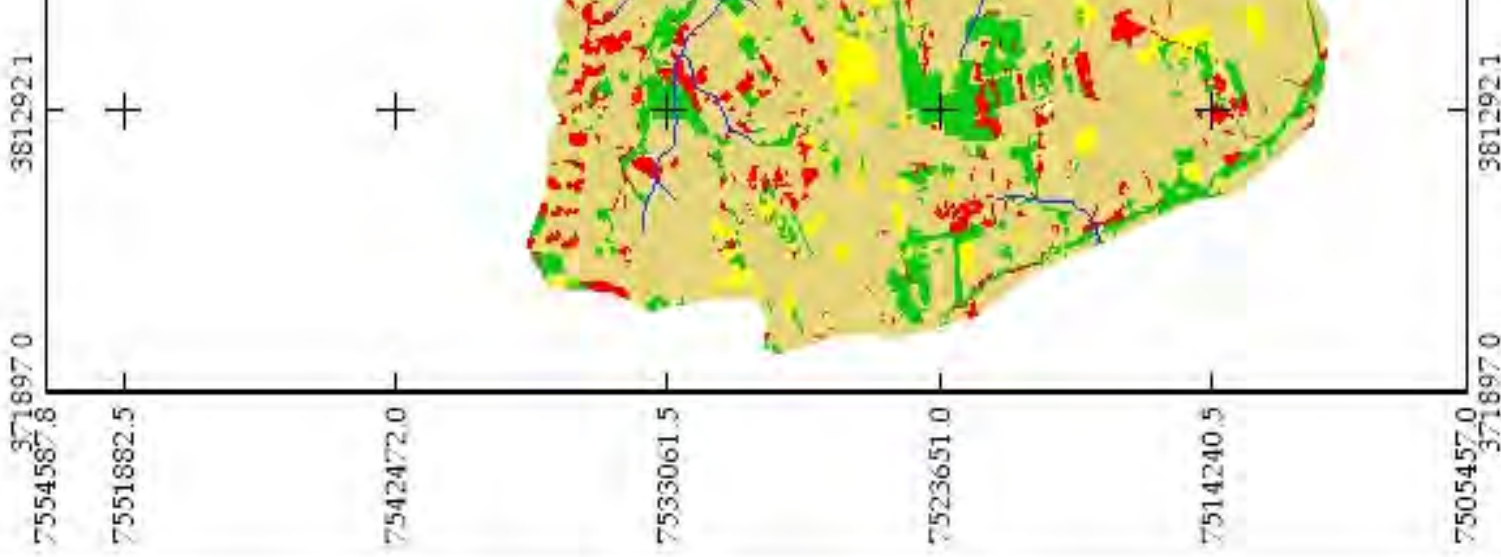


As imagens evidenciam o aumento significativo das áreas de pastagens no município e o recuo das lavouras (este principalmente entre os anos de 1985 e 1995). A imagem referente ao ano de 2005 nos remete a pensar (em comparação às anteriores) na preponderância da atividade pecuária em Mirante do Paranapanema por um longo período de tempo, muito embora esta mesma imagem apresente um discreto aumento das áreas de lavouras.

Assim, podemos dizer que o processo de construção histórica da paisagem em Mirante do Paranapanema resultou em um atual estado de relativa homogeneidade fisionômica que é conferido pela atividade pecuária, pelas pastagens. Certamente isso não significa que tal atividade será permanente. Por meio de nossos trabalhos de campo pudemos tomar notas de algumas propriedades nas quais se vem plantando cana-deaçúcar.

A seguinte seqüência de acontecimentos: desmatamentos-agricultura-pastagens (claramente visualizados nas imagens anteriores) e as possibilidades abertas pela retomada da agricultura (com vistas à produção de cana) nos dias de hoje, implicaram e implicam uma série de impactos socioambientais na área de estudo.

Estes impactos podem ser apreendidos, notadamente, por produzirem singularidades paisagísticas diretamente identificáveis no território de Mirante do Paranapanema...

\section{3) As dinâmicas socioambientais e suas singularidades paisagísticas}

Conforme dito anteriormente, podemos verificar clara e diretamente no território do município algumas peculiaridades/singularidades na paisagem que nos remetem à discussão sobre as dinâmicas socioambientais nesta área de estudo. Trataremos deste assunto no presente item do capítulo.

Em Mirante do Paranapanema, observamos diversos pontos onde se desdobram problemas de erosões, assoreamentos e empobrecimento do solo. Há uma remodelação da paisagem definida pela intensidade da ação antrópica caracterizada por formas de ocupação e usos agropecuários inadequados. 
Estes modos de produção se materializaram/materializam sobre o meio natural, sobre o potencial geoecológico, permitindo-nos observar as especificidades das lógicas que geraram rupturas na dinâmica natural dos elementos físicos da paisagem.

Via de regra, as alterações antrópicas em Mirante do Paranapanema estão correlacionadas ao modelo dominante de ocupação socioeconômica da região do Pontal como um todo, isto é, por meio do desmatamento (muitas vezes com a formação de pastagens) e uso do solo de modo a gerar seu verdadeiro exaurimento e posterior criação de gado.

Geralmente a percepção dos colonizadores esteve ligada à derrubada da mata enquanto maneira de efetivação da posse e garantia do patrimônio. Portanto, a área está historicamente estigmatizada por práticas agrícolas bastante inadequadas, propulsoras de processos erosivos por conta de incisivas alterações impostas à cobertura vegetal.

Passos (1988, p.153) em seu estudo de Geografia Física Global sobre o Pontal do Paranapanema, comparou mapas de uso do solo de 1962 e 1972 constatando que os desmatamentos no período se efetivaram nos baixos espigões e encostas, ou seja, nas áreas potencialmente propícias à agricultura na região.

O que o referido autor chama de "área core" 35 do Pontal, durante a década de 1960 ainda apresentava uma expressiva cobertura vegetal, enquanto que em sua área mais "periférica" havia predominância de culturas anuais e perenes, sobretudo no município de Mirante do Paranapanema cujo parcelamento intenso dos lotes agrícolas denotava uma super-exploração econômica, fato este responsável pela aceleração dos impactos ambientais desde aquela época.

Em trabalhos de campo na área rural do município, visualizamos singularidades paisagísticas bastante pertinentes para exemplificar os fatos acima destacados, ou seja,

\footnotetext{
35 Na obra citada e também: "O Pontal do Paranapanema ocupa a porção Extremo-Oeste do Estado de São Paulo. É uma 'mesopotâmia', limitada ao norte pelo Rio Paraná, ao sul pelo Rio Paranapanema, a oeste pela confluência desses dois rios. O seu limite leste deslocou-se ao sabor do avanço da fronteira agrícola. Atendendo às características do processo de ocupação, optamos pelo Ribeirão das Anhumas - vertente do Rio Paraná - e pelo Ribeirão do Engano ou Santo Antônio - vertente do Rio Paranapanema - como seu limite leste. Podemos chamar essa área [...] de 'área core do Pontal', tendo em vista que, no início da década de 1940 do século XX, uma porção territorial maior, englobando os atuais municípios de Mirante do Paranapanema, Sandovalina e Marabá Paulista, constituíam um espaço paulista, marginalizado e que preferimos chamar de 'Grande Pontal'”. (PASSOS, 2007, p.15-16)
} 
significativos pontos indicadores de uma dinâmica resistásica resultante das ações antrópicas acumuladas no tempo e deixando seus rastros negativos sobre o espaço, sobre a natureza.

A microbacia do ribeirão Santo Antônio que se configura por sua drenagem entalhada na área rural do município de Mirante do Paranapanema (seguindo o sentido de norte a sul, conforme exposto na figura 6), exemplifica os reflexos do uso predatório do solo.

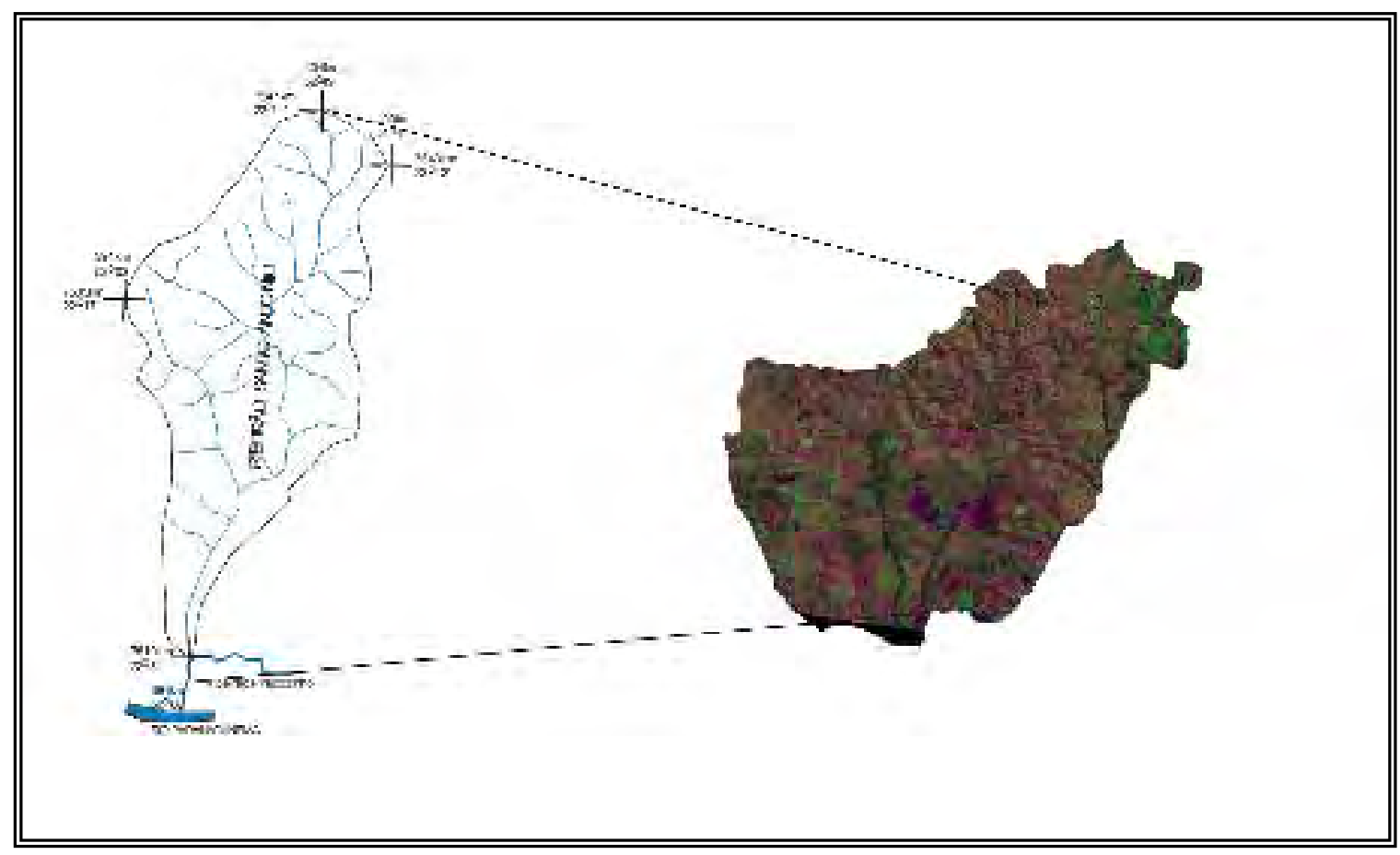

Figura 6: Localização da bacia do ribeirão Santo Antônio em Mirante do Paranapanema. Orgs: LIMA, Valéria; SOUZA, Reginaldo J. Fonte do recorte da bacia: TORRES (2003).

Torres (2003), em sua análise sobre as transformações históricas e a dinâmica atual da paisagem nesta microbacia, chama atenção para seus principais aspectos naturais a partir da caracterização mais geral do Extremo Oeste paulista:

Em linhas gerais, a geologia do Extremo Oeste Paulista, onde se encontra o município de Mirante do Paranapanema e neste o ribeirão Santo Antônio, é constituída, na sua maior parte, por rochas sedimentares com idade aproximada de 65 milhões de anos (Era Mesozóica) e também por coberturas mais recentes entre 11 e 15 milhões de anos (Era Cenozóica) com predomínio de aluviões (depósitos de cascalhos, areia e argila transportados por ações das chuvas, dos ventos 
e dos rios) e coluviões (solos das vertentes formados de detritos transportados pela gravidade).

As feições geomorfológicas apresentam uma sucessão de colinas suavizadas compostas por espigões areníticos (rochas constituídas de grãos de areia consolidados por cimento carbonático) que vão se rebaixando até o rio Paraná. No caso do ribeirão Santo Antônio, o predomínio é de colinas amplas.

Quanto aos solos, BOIN (2000) afirma que são na sua maioria arenosos, pouco ácidos, pobres em argila, originados da decomposição do Arenito do Grupo Bauru, apresentando uma quantidade grande de areia em sua composição. Quanto à profundidade, variam de 1 a 3 metros, bem drenados, podendo apresentar cimento carbonático ou silicoso, sendo, normalmente, friáveis demonstrando sua fragilidade. O predomínio na microbacia [...] é de solos podzólicos e latossolos vermelho-escuro. Vale lembrar que os solos do Oeste paulista apresentam relações litológicas e geomorfológicas que indicam sua suscetibilidade à erosão. Estas características propiciam uma degradação dos recursos hídricos por processos da dinâmica superficial (como erosão e assoreamento), entre outras. (TORRES, 2003, p. 65-66, grifo nosso)

As características físicas da microbacia em si e em conjunto com o tipo de ocupação/uso aos quais ela foi/é destinada, são verdadeiros indicadores de uma série de problemas ambientais que reclama por ações urgentes no que diz respeito à reversão do atual quadro de degradação em que ela se encontra. (ver quadro fotográfico I, p.116)

Conforme expusemos, desde momentos anteriores (meados da década de 1940) a sua emancipação político-administrativa (ano de 1953), este município foi palco de um tipo de ocupação agrícola que provocou sérios agravos socioambientais.

No passado, sobretudo até a década de 1970, não existiam preocupações com a necessidade de proteção do solo por parte dos proprietários agrícolas. Passos (1988, p.162) salienta que em entrevistas realizadas junto aos ex-lavradores do Pontal do Paranapanema, naquela época, as respostas obtidas sempre foram negativas quando interrogados a respeito de utilização de curvas de nível em suas terras ou se tinham alguma orientação técnica de agrônomos. Em entrevistas informais que realizamos - em nossos trabalhos de campo - com alguns assentados oriundos do MST, tomamos nota de que muitos deles continuam sem ter este aparato técnico que os auxiliem no manejo de suas terras.

Atualmente, Mirante do Paranapanema não tem mais o mesmo destaque, como no passado, com relação ao uso agrícola intensivo, notadamente no que tange ao plantio 
de café, algodão e amendoim. Essa constatação está fundamentada, inclusive, na observação in loco de prédios abandonados das indústrias beneficiadoras destes produtos (Anderson Clayton, Braswey, Sanbra, Macfaden) na área urbana, que evidenciam o fenômeno da desterritorialização de uma intensa atividade agrícola do passado. (ver quadro fotográfico IV, pg.119) Hoje em dia são (1) a pecuária leiteira (pouco desenvolvida) e (2) a chegada da cana-de-açúcar os elementos mais expressivos da economia local.

Um problema verificado (uma singularidade paisagística) na área estudo é a contribuição das estradas rurais para os impactos ambientais. Durante as décadas de 1970/1980, a abertura das estradas dentro das propriedades não obedecia a nenhuma orientação técnica e a erosão em sulcos, nessas estradas, era muito acentuada. (PASSOS, 1988, p.163)

Nos dias de hoje, verificamos algumas medidas no âmbito do Programa Melhor Caminho, de iniciativa do Governo Estadual, sob coordenação da Secretaria de Agricultura e Abastecimento e a CODASP (Companhia de Desenvolvimento Agrícola de São Paulo) como executora das obras. O programa contemplou o município com cerca de oito quilômetros em melhorias nas vias rurais com o objetivo maior de sanar os problemas gerados a partir da má conservação das estradas ${ }^{36}$. Entretanto, o problema da erosão, muitas vezes, ainda é agravado pela presença majoritária de estradas má conservadas. Gerando maiores preocupações quando se desdobra em áreas de nascentes dos córregos e ribeirões.

É o caso de uma das nascentes do ribeirão Santo Antônio onde pudemos identificar processos erosivos bastante intensos, com presença de solo hidromorfizado indicando maior largura do leito do córrego no passado e perda do capeamento de latossolo, principalmente a partir da margem de uma estrada nas suas proximidades.

Outro aspecto importante a ser tratado no que diz respeito a esta área (média a alta bacia do ribeirão Santo Antônio) é o próprio parcelamento das propriedades rurais. Geralmente lotes de sete, oito ou dez alqueires no máximo, que se destinam à pecuária leiteira. Fato este que, aliado à acentuada declividade das vertentes, ao baixo grau de

\footnotetext{
${ }^{36}$ Informação obtida em visita técnica à Prefeitura Municipal em março de 2008.
} 
permeabilidade do solo (sobre formações mais resistentes à infiltração - Arenito Bauru carbonatado) e práticas pouco, ou quase nada, conservacionistas, geram processos erosivos mais críticos.

Entendemos, portanto, que os impactos ambientais na referida área são resultados de ações antrópicas sistematicamente desorganizadas. Tudo começou com o intenso desmatamento para garantir a posse da terra no passado, perpassando pelos diferentes usos agrícolas do solo, esgotamento, formação de pastos e pecuária leiteira. E, contribuindo com isso, a presença de algumas estradas que aceleram o escoamento superficial das águas, gerando assoreamento dos córregos e supressão de nascentes por meio dos processos erosivos.

Outras singularidades paisagísticas se apresentaram muito interessantes enquanto indicadoras de uma condição de "abandono" nas propriedades rurais em Mirante do Paranapanema. Em uma de nossas saídas a campo (maio de 2008), conosco esteve presente um morador da área rural do município cujas respostas às nossas perguntas, de maneira informal, foram reveladoras do processo de degradação existente às margens dos cursos d'água no local.

Ainda seguindo o curso do ribeirão Santo Antônio, o entrevistado dizia que sua correnteza era superior no passado (cerca de 30 anos atrás) quando comparada aos dias atuais. Enquanto fotografávamos a área, destacavam-se na paisagem grandes bancos de areia nas margens e até mesmo no interior do curso d'água. (ver quadro fotográfico I, pg.116) A correnteza do córrego realmente não poderia mais ser a mesma em uma área de ocupação agrícola mais antiga (alta e média bacia) e sem maiores preocupações com práticas de proteção do solo nas vertentes, sobretudo nos períodos em que as chuvas não estão presentes como na estação úmida. Todos estes fatores se combinam para resultar em um quadro de assoreamento e aguda desperenização.

Em sua Tese de Doutorado, Passos constatou que:

O Córrego Guaiçara [...] - no Município de Presidente Bernardes - e o Córrego do Engano ${ }^{37}$ no Município de Mirante do Paranapanema são os que mais chamam a atenção, visto que o assoreamento dos seus leitos

${ }^{37}$ Córrego do Engano ou Santo Antônio: trata-se do mesmo córrego, porém, assumindo denominações locais diferentes. 
elevou o nível desses "rios" - que há cerca de 15-20 anos atrás passava sob as principais pontes a 8-10 metros abaixo e hoje estão apenas 2-3 metros.

A agressividade com que se processou a ocupação do solo, sobretudo nas áreas agrícolas e nas pequenas propriedades, resultou numa fragilidade do geossistema em análise: mesmo pancadas de chuvas não muito excepcionais, são causadoras de estragos, apesar de tratar-se de um espaço geográfico caracterizado por certa homogeneidade geomorfológica, litológica e climatológica.

No período seco, os processos morfogenéticos relacionados ao escoamento superficial se mantêm inativos. É nesse período que o processo de assoreamento e de desperenização dos córregos e ribeirões se evidencia. Vários trechos de alguns ribeirões chegam a secar totalmente. (PASSOS, 1988, p.98)

Vinte anos após esta observação, verificamos a intensificação destes processos, fazendo jus às palavras do entrevistado que conosco percorria trechos do córrego em nosso trabalho de campo. Outro aspecto percebido é a freqüente ocorrência de erosão por solapamento em vários pontos do curso do ribeirão Santo Antônio, sobretudo da média para a alta bacia, onde a agricultura se deu de modo mais predatório e o ambiente apresenta topografia bastante movimentada - fatores que potencializam o agressivo lesionamento paisagístico. (ver quadro fotográfico I, pg.116)

Este fato nos remete a uma reflexão sobre a própria ação antropogênica influenciando no modelado do relevo e definindo, em conjunto com a dinâmica climato-hidrológica, o desdobramento de eventos negativos que rompem com o equilíbrio ambiental na área. Nos meses mais chuvosos e de temperaturas mais elevadas, geralmente de dezembro a fevereiro, há significativos impactos sobre os processos morfo e pedogenéticos na área.

O nível do leito do córrego se eleva de modo significativo, a velocidade e volume das águas acabam por carregar as camadas de solo das margens, definindo também os pontos de hidromorfização e conseqüente formação de brejos, evidenciada pela presença de taboas (Typha domingensis), espécie indicadora da umidade do solo.

Ilustrando a seriedade do problema de assoreamento/desperenização dos ribeirões em Mirante do Paranapanema, temos o córrego Águas da Saúde, no qual existem pontos em que é possível observar a presença de cercas - entre propriedades cravadas praticamente no meio do leito. (ver quadro fotográfico I, pg.116) 
É válido ressaltar que, a nosso ver, os problemas anteriormente apontados nunca devam ser encarados em um viés fatalista, no qual a responsabilidade maior pela tríade erosão-assoreamento-desperenização seja atribuída às chuvas e baixa resistência do solo na área. A sociedade não tem poder sobre a dinâmica dos processos naturais, porém, pode amenizar seus efeitos até mesmo com o objetivo de beneficiar-se com isso. Afinal, quando pensamos na relação homem-natureza, fica implícito que se trata de uma espécie de jogo em que ações negativamente exercidas sobre a natureza geram respostas na mesma proporção para a sociedade.

O olhar sobre a paisagem de Mirante do Paranapanema nos revela a importância da criação de gado para a economia local. Em contrapartida, também vemos a incidência de processos erosivos, assoreamento, desperenização e formação de brejos (impedindo o acesso do gado à água): um quadro de fatos que são prejudiciais à própria manutenção da atividade.

Os prejuízos com essa forma desleixada de manejar o solo e a propriedade agrícola como um todo, têm causado sérios prejuízos ao balanço hidrológico e à economia regional, bastando lembrar que a compactação do solo pela erosão pluvial limita a infiltração e favorece o escoamento superficial, drenando as águas precipitadas para fora da região ${ }^{38}$, cuja carência hídrica se manifesta a cada ano que passa com maior gravidade. Os prejuízos econômicos, resultantes desse processo, são bem evidentes para quem avalia os efeitos da erosão e do déficit hídrico sobre a pedogênese e relaciona tal fato com a baixa capacidade de apascentamento das pastagens [...]. (PASSOS, 1988, p.98)

De modo geral, é a eliminação da cobertura vegetal um dos fatores determinantes do início da fase resistásica nos geocomplexos. A incorporação socioeconômica do Pontal do Paranapanema esteve intrinsecamente ligada à prática latifundiária dos colonizadores pela posse da terra, notadamente na via dos desmatamentos intensivos e ostensivos. Porém, em algumas glebas o desmatamento não foi o princípio deste processo de ocupação. Sobretudo na "área core" do Pontal do Paranapanema, muitas vezes o capim para o boi conviveu com a mata antes que ela fosse derrubada. (Cf. PASSOS, 1988)

\footnotetext{
${ }^{38}$ Região do Pontal do Paranapanema.
} 
Desta forma, podemos dizer que os impactos negativos nas áreas do extremo oeste da região do Pontal do Paranapanema foram relativamente menos agressivos (à época de início da colonização) do que aqueles ocorridos em áreas essencialmente agrícolas, muitas vezes com cultivos permanentes por quase vinte anos seguidos (algodão, por exemplo): como foi o caso de Mirante do Paranapanema desde a sua fundação.

Até o momento não nos esquivamos em falar dos reflexos negativos do modelo histórico de construção territorial no/do município. Acreditamos que os impactos socioambientais nele existentes são frutos da cultura imediatista de exploração e degradação dos recursos naturais. E este tipo de comportamento certamente persiste nos dias de hoje por parte de alguns proprietários rurais.

Um exemplo que podemos destacar é o caso da Fazenda Boa Esperança (de propriedade da empresa Prefer Agropecuária Ltda), entre os municípios de Presidente Bernardes e Mirante do Paranapanema. Na área da fazenda observamos uma singularidade paisagística definida pela degradação em nome do lucro. (ver quadro fotográfico II, pg.117)

Conforme Parecer Técnico (036-2006) do Ministério Público do Estado de São Paulo, a empresa foi denunciada devido à aplicação ilegal de agrotóxico na área da fazenda e possibilidade de supressão da vegetação após seu envenenamento.

A descrição da vistoria feita na fazenda (Parecer Técnico nº. 036-2006, Ministério Público de SP) demonstra que, na propriedade, o solo vem sendo preparado para receber o plantio da cana-de-açúcar. Em visita à fazenda, constatamos que o interesse pela implantação deste agrossistema possivelmente se orienta pela própria extensão da área e por sua topografia suave. Logo, este quadro de possibilidades fez com que interesses econômicos suprimissem o bom senso em se adotar práticas menos predatórias em benefício tanto da natureza quanto da sociedade local.

Infelizmente este não é o único caso de grave degradação ambiental no município. Em visitas técnicas ao Ministério Público do Estado de São Paulo, entramos em contato com documentos (pareceres técnicos resultantes de vistorias em 
propriedades) que contém descrições de outras situações alarmantes. (conferir quadro 5)

Quadro 5: Informações coletadas no Ministério Público do Estado de São Paulo

\begin{tabular}{|c|c|c|c|c|c|}
\hline \multicolumn{6}{|c|}{ PARECERES TÉCNICOS DE VISTORIAS EM PROPRIEDADES (PROMOTORIA DO MEIO AMBIENTE) } \\
\hline $\begin{array}{l}\text { Pareceres } \\
\text { técnicos } \\
\text { consultados }\end{array}$ & $\begin{array}{c}\text { Número } \\
\text { do } \\
\text { parecer }\end{array}$ & Local & Assunto & Interessado & Constatações \\
\hline $\begin{array}{l}\text { 1- } \\
\text { Assentamento } \\
\text { Che Guevara }\end{array}$ & $\begin{array}{l}194- \\
2005\end{array}$ & $\begin{array}{c}\text { Mirante do } \\
\text { Paranapanema }\end{array}$ & $\begin{array}{l}\text { Análise de áreas } \\
\text { protegidas por meio de } \\
\text { imagens de satélite }\end{array}$ & $\begin{array}{l}\text { Ministério } \\
\text { Público SP }\end{array}$ & $\begin{array}{c}23 \text { assentamentos estão sobre } \\
\text { áreas das quais dispõem a lei } \\
4771 / 65\end{array}$ \\
\hline $\begin{array}{c}\text { 2-Glebas } 093 \text { e } \\
1169\end{array}$ & $\begin{array}{l}201- \\
2005\end{array}$ & $\begin{array}{c}\text { Mirante do } \\
\text { Paranapanema } \\
\text { (11o Perímetro) }\end{array}$ & $\begin{array}{l}\text { Vistoria em área de } \\
\text { preservação } \\
\text { permanente (áreas de } \\
\text { vegetação nativa em } \\
\text { estado de regeneração) } \\
\text { ao longo do Córrego } \\
\text { Figueira e Veado } \\
\text { (Distrito Costa } \\
\text { Machado); } \\
\text { Presença de animais } \\
\text { pastorando em áreas de } \\
\text { preservação. } \\
\text { Lançamento de } \\
\text { efluentes da ETE39 de } \\
\text { Mirante. }\end{array}$ & $\begin{array}{l}\text { Ministério } \\
\text { Público SP }\end{array}$ & $\begin{array}{l}\text { Apresentação de medidas a } \\
\text { serem tomadas no sentido de } \\
\text { se eliminar fatores de } \\
\text { degradação existentes sobre as } \\
\text { glebas. }\end{array}$ \\
\hline $\begin{array}{l}\text { 3- } \\
\text { Assentamento } \\
\text { Antonio } \\
\text { Conselheiro }\end{array}$ & $\begin{array}{l}247- \\
2005\end{array}$ & $\begin{array}{c}\text { Mirante do } \\
\text { Paranapanema }\end{array}$ & $\begin{array}{l}27 \text { lotes do } \\
\text { assentamento estão } \\
\text { localizados sobre } \\
\text { APPs }^{40} \text {. }\end{array}$ & $\begin{array}{l}\text { Ministério } \\
\text { Público SP }\end{array}$ & $\begin{array}{l}\text { Exploração irregular das áreas } \\
\text { de preservação feita pelos } \\
\text { assentados. A área do } \\
\text { assentamento não dispõe dos } \\
20 \% \text { de área preservada } \\
\text { previstos em lei. } \\
\text { Comprometimento do Ribeirão } \\
\text { Nhacá. }\end{array}$ \\
\hline $\begin{array}{l}\text { 4- } \\
\text { Assentamento } \\
\text { Paulo Freire }\end{array}$ & $\begin{array}{l}248- \\
2005\end{array}$ & $\begin{array}{c}\text { Mirante do } \\
\text { Paranapanema }\end{array}$ & $\begin{array}{c}32 \text { lotes do } \\
\text { assentamento estão } \\
\text { localizados sobre a APP. }\end{array}$ & $\begin{array}{l}\text { Ministério } \\
\text { Público SP }\end{array}$ & $\begin{array}{l}\text { Eventual exploração de áreas } \\
\text { protegidas pelos assentados. } \\
\text { Não há } 20 \% \text { de área } \\
\text { preservada conforme } \\
\text { determina a lei. } \\
\text { O INCRA que aponta estas } \\
\text { áreas para os assentados. }\end{array}$ \\
\hline
\end{tabular}

(Continua...)

${ }^{39}$ Estação de tratamento de esgoto.

40 Áreas de preservação permanente. 


\begin{tabular}{|c|c|c|c|c|c|}
\hline \multicolumn{6}{|c|}{ PARECERES TÉCNICOS DE VISTORIAS EM PROPRIEDADES (PROMOTORIA DO MEIO AMBIENTE) } \\
\hline $\begin{array}{c}\text { Pareceres } \\
\text { técnicos } \\
\text { consultados }\end{array}$ & $\begin{array}{l}\text { Número } \\
\text { do } \\
\text { parecer }\end{array}$ & Local & Assunto & Interessado & Constatações \\
\hline $\begin{array}{c}\text { 7-Distrito de } \\
\text { Cuiabá } \\
\text { Paulista }\end{array}$ & $\begin{array}{l}398- \\
2006\end{array}$ & $\begin{array}{c}\text { Mirante do } \\
\text { Paranapanema }\end{array}$ & $\begin{array}{c}\text { Processos erosivos no Sítio } \\
\text { Nossa Senhora Aparecida } \\
\text { decorrentes do } \\
\text { encaminhamento de águas } \\
\text { pluviais de forma } \\
\text { inadequada do distrito de } \\
\text { Cuiabá Paulista e falta de } \\
\text { práticas de conservação do } \\
\text { solo nas propriedades } \\
\text { rurais próximas a área } \\
\text { urbana. } \\
\text { Bacias do Córrego } \\
\text { Ravenagora e Ribeirão } \\
\text { Nhacá. }\end{array}$ & $\begin{array}{l}\text { Ministério } \\
\text { Público SP }\end{array}$ & $\begin{array}{l}\text {-erosão provocada pelo } \\
\text { lançamento de águas pluviais } \\
\text { urbanas de forma inadequada } \\
\text { pelo distrito de Cuiabá Paulista; } \\
\text { falta de disciplinamento das } \\
\text { águas pluviais concentradas na } \\
\text { rodovia; falta de práticas de } \\
\text { conservação do solo nas } \\
\text { propriedades rurais; ausência } \\
\text { da reserva florestal legal nas } \\
\text { propriedades rurais; ausência } \\
\text { de vegetação em área de } \\
\text { preservação permanente; } \\
\text { ocupação irregular das áreas de } \\
\text { preservação permanente. }\end{array}$ \\
\hline
\end{tabular}

(Continua...) 


\begin{tabular}{|c|c|c|c|c|c|}
\hline \multicolumn{6}{|c|}{ PARECERES TÉCNICOS DE VISTORIAS EM PROPRIEDADES (PROMOTORIA DO MEIO AMBIENTE) } \\
\hline $\begin{array}{l}\text { Pareceres } \\
\text { técnicos } \\
\text { consultados }\end{array}$ & $\begin{array}{l}\text { Número } \\
\text { do } \\
\text { parecer }\end{array}$ & Local & Assunto & Interessado & Constatações \\
\hline $\begin{array}{l}\text { 8-Fazenda Sol } \\
\text { Nascente }\end{array}$ & $\begin{array}{c}019- \\
2007\end{array}$ & $\begin{array}{c}\text { Mirante do } \\
\text { Paranapanema } \\
\text { (direção sudeste a } \\
\text { partir da cidade) }\end{array}$ & $\begin{array}{c}\text { Exploração de áreas } \\
\text { protegidas }\end{array}$ & $\begin{array}{l}\text { Ministério } \\
\text { Público SP }\end{array}$ & $\begin{array}{l}\text { Uso nocivo da propriedade } \\
\text { sem conservação das } \\
\text { áreas de proteção } \\
\text { permanente e reservas } \\
\text { florestais. Reservas } \\
\text { florestais não existem e as } \\
\text { APPs foram usadas para o } \\
\text { plantio de cana-de-açúcar. }\end{array}$ \\
\hline $\begin{array}{l}\text { 9-Fazenda } \\
\text { Saad }\end{array}$ & $\begin{array}{l}169- \\
2007\end{array}$ & $\begin{array}{c}\text { Mirante do } \\
\text { Paranapanema }\end{array}$ & $\begin{array}{c}\text { Eventual cobertura } \\
\text { florestal e exploração de } \\
\text { áreas protegidas e } \\
\text { cumprimento do } \mathrm{TAC}^{41} \text {. }\end{array}$ & $\begin{array}{l}\text { Ministério } \\
\text { Público SP }\end{array}$ & $\begin{array}{l}\text { As APPs estão ocupadas } \\
\text { com pastoreio e as } \\
\text { reservas legais não } \\
\text { totalizam } 20 \% \text { da área da } \\
\text { propriedade conforme } \\
\text { especifica a lei. } \\
\text { Inexistência de mata ciliar } \\
\text { ao longo do Córrego } \\
\text { Nhacá. } \\
\text { Uso nocivo da } \\
\text { propriedade. }\end{array}$ \\
\hline $\begin{array}{l}\text { 10-Fazenda } \\
\quad \text { Boa } \\
\text { Esperança }\end{array}$ & $\begin{array}{l}036- \\
2006\end{array}$ & $\begin{array}{l}\text { Presidente } \\
\text { Bernardes }\end{array}$ & $\begin{array}{c}\text { Eventual contaminação } \\
\text { de animais silvestres } \\
\text { pela aplicação de } \\
\text { agrotóxicos e eventual } \\
\text { concessão de } \\
\text { autorização para corte } \\
\text { raso de vegetação nativa } \\
\text { consistida de “árvores } \\
\text { isoladas". }\end{array}$ & $\begin{array}{l}\text { Denúncia sobre } \\
\text { aplicação de } \\
\text { agrotóxico com } \\
\text { conseqüente } \\
\text { mortandade de } \\
\text { animais } \\
\text { silvestres. }\end{array}$ & $\begin{array}{l}\text { APPs degradadas com } \\
\text { pastoreio e desmatamento } \\
\text { para formação de } \\
\text { pastagens (Córrego da } \\
\text { Cobra). A área de Reserva } \\
\text { Florestal não atinge os } \\
20 \% \text { da propriedade } \\
\text { conforme determinado } \\
\text { por lei. }\end{array}$ \\
\hline
\end{tabular}

Org.: Reginaldo J. Souza

\footnotetext{
41 Termo de ajustamento de conduta.
} 
As informações contidas no quadro anterior demonstram a freqüência, em Mirante do Paranapanema, dos casos de degradação em áreas que, conforme a legislação, deveriam ser consideradas como APPs (Áreas de Preservação Permanente) ou Reserva Florestal Legal. Geralmente os proprietários não respeitam a legislação (ou são levados a explorar estas reservas pelo fato de não terem outras áreas para desenvolver suas atividades, como ocorre em lotes de assentamentos rurais de reforma agrária).

Por outro lado, existem algumas ações que representam mudanças relativamente positivas, materializadas na paisagem de Mirante do Paranapanema. Não poderíamos deixar de tratá-las enquanto determinantes de outra possível dinâmica socioambiental no município (possível porque ainda não completamente consolidada).

Este é o caso do bairro rural Colônia Branca que conta com os benefícios do Programa Microbacias Hidrográficas. (ver quadro fotográfico III, pg.118) Uma das metas do programa é o investimento em infra-estrutura rural, incluindo a conservação das estradas, no sentido de beneficiar o morador da área rural bem como minimizar a ação das erosões do solo por meio da implantação de "murundus" e "camalhões" ao longo dos trajetos das vias, contribuindo para a diminuição da velocidade de escoamento superficial das águas e conseqüente transporte de material por enxurradas.

A produção agrícola no bairro (Colônia Branca) é relativamente diversificada, o que pudemos visualizar foram plantações de cana-de-açúcar, arroz e tomate, além da criação de gado. Mesmo não se tratando de uma área plenamente desenvolvida, talvez seja representativa de algumas medidas que possam minimizar boa parte dos impactos negativos existentes no município.

Nas áreas de assentamento de reforma agrária, notamos lotes sem cultivos diversificados. (ver quadro fotográfico III, pg.118) A infra-estrutura geralmente é insatisfatória (caso ela, de fato, exista). Os assentados não contam com assistência técnica especializada, conforme respostas de dois entrevistados. A base da produção é a pecuária leiteira com vistas a um laticínio de Presidente Prudente. Realizamos entrevistas informais com alguns moradores que mostraram sua insatisfação com os preços baixos pagos pelo laticínio, mas, sobretudo pela falta de assistência técnica que 
contribua para melhor manejo das pastagens. A má qualidade destas, sobretudo na estação seca, potencializa a queda da qualidade do leite e, em conseqüência, diminui o seu valor no mercado enquanto matéria prima para os laticínios.

Basicamente foram estes os principais aspectos das dinâmicas socioambientais apreendidos no município. Nós consideramos a multiplicidade de determinações que levaram à configuração da estética paisagística em Mirante do Paranapanema: suas singularidades foram/são determinadas por ações antrópicas que atuaram/atuam de modo incisivo e predatório sobre o solo, vegetação, relevo e hidrografia.

Neste sentido, reafirmamos a importância assumida pela paisagem, enquanto categoria de análise geográfica, para apreendermos a dinâmica atual do território e adentrarmos na questão ambiental. É preciso partir de um sistema de referências da paisagem para se chegar a reflexões mais aprofundadas a respeito do jogo de relações que determina a sua configuração. A paisagem evidencia a organização ou desorganização do território de Mirante do Paranapanema, ou seja, o modo como estão dispostos os impactos da ação humana sobre o meio ambiente territorializado.

Assim, enfatizamos que é possível identificar especificidades paisagísticas na interface natureza-sociedade, mesmo em uma área que em princípio se apresenta como possuidora de relativa homogeneidade fisionômica devido à predominância de uma atividade econômica específica (como é o caso da pecuária). A distribuição espacial das singularidades paisagísticas observadas por meio dos nossos trabalhos de campo, em Mirante do Paranapanema, será apresentada na próxima figura (fig. 7, p.115). A visualização desta figura deverá ser acompanhada da leitura do quadro-síntese das singularidades paisagísticas (quadro 3, p. 114) em sinergia a uma série de quadros fotográficos (I, II, III e IV /pg. 116, 117, 118 e 119, respectivamente) com imagens que as representam. 
Quadro 3: Singularidades paisagísticas diretamente observáveis no território de Mirante do Paranapanema

\begin{tabular}{|c|c|c|c|}
\hline $\begin{array}{l}\text { Singularidade } \\
\text { paisagística }\end{array}$ & Nomenclatura & Descrição & Critério de apreensão \\
\hline 1 & $\begin{array}{l}\text { Áreas de pastagens com } \\
\text { produção leiteira }\end{array}$ & $\begin{array}{l}\text { Pequenos lotes entre 16 e } \\
24 \text { hectares } \\
\text { (atendidos ou não pelos } \\
\text { programas Microbacias } \\
\text { Hidrográficas ou Melhor } \\
\text { Caminho) }\end{array}$ & $\begin{array}{l}\text { Socioeconômico (áreas de } \\
\text { assentamentos rurais de } \\
\text { reforma agrária) }\end{array}$ \\
\hline 2 & $\begin{array}{l}\text { Áreas de produção } \\
\text { leiteira com agricultura } \\
\text { de subsistência }\end{array}$ & $\begin{array}{l}\text { Pequenas e médias } \\
\text { propriedades em bairro } \\
\text { rural (atendidas ou não } \\
\text { pelos programas } \\
\text { Microbacias Hidrográficas } \\
\text { ou Melhor Caminho) } \\
\end{array}$ & $\begin{array}{l}\text { Socioeconômico (pequenas e } \\
\text { médias propriedades com } \\
\text { produção voltada para o } \\
\text { mercado local bem como para } \\
\text { o consumo familiar) }\end{array}$ \\
\hline 3 & $\begin{array}{c}\text { Áreas de margens e } \\
\text { nascentes degradadas } \\
\text { com vegetação (ciliar) } \\
\text { inexistente ou em } \\
\text { dinâmica regressiva }\end{array}$ & $\begin{array}{l}\text { Nascentes e cursos de } \\
\text { córregos (por exemplo: } \\
\text { Bacia do Santo Antônio) }\end{array}$ & $\begin{array}{l}\text { Naturalista/Geossistêmico e } \\
\text { antrópico; Geótopos e } \\
\text { geofácies degradados. }\end{array}$ \\
\hline 4 & $\begin{array}{l}\text { Vertentes com processos } \\
\text { erosivos e/ou vegetação } \\
\text { inexistente }\end{array}$ & $\begin{array}{c}\text { Comuns em toda área do } \\
\text { município }\end{array}$ & $\begin{array}{l}\text { Naturalista/Geossistêmico e } \\
\text { antrópico; } \\
\text { Geofácies em desequilíbrio } \\
\text { geoecológico, caracterizado } \\
\text { por processos de erosão em } \\
\text { sulcos, desmatamento ou } \\
\text { eventual envenenamento de } \\
\text { reserva florestal. } \\
\end{array}$ \\
\hline 5 & $\begin{array}{l}\text { Assoreamento de } \\
\text { córregos }\end{array}$ & $\begin{array}{l}\text { Vários pontos críticos ao } \\
\text { longo dos córregos do } \\
\text { município (por exemplo: } \\
\text { alto e médio curso do } \\
\text { Córrego Santo Antônio e } \\
\text { Águas da Saúde) }\end{array}$ & $\begin{array}{c}\text { Naturalista/Geossistêmico; } \\
\text { Geótopos marcados por } \\
\text { processos erosivos de } \\
\text { solapamento e afloramentos } \\
\text { de bancos de areia na lâmina } \\
\text { d'água. }\end{array}$ \\
\hline 6 & Agrossistema canavieiro & $\begin{array}{c}\text { Grandes propriedades (por } \\
\text { exemplo: acima dos } 1000 \\
\text { hectares) }\end{array}$ & $\begin{array}{l}\text { Socioeconômico (forma de } \\
\text { produção agrícola } \\
\text { essencialmente capitalista). }\end{array}$ \\
\hline 7 & $\begin{array}{c}\text { Ícones da } \\
\text { desterritorialização }\end{array}$ & $\begin{array}{l}\text { Prédios das beneficiadoras } \\
\text { de algodão e antigas } \\
\text { residências abandonadas } \\
\text { na área urbana }\end{array}$ & $\begin{array}{l}\text { Histórico: representações } \\
\text { remanescentes de um } \\
\text { passado onde a lavoura esteve } \\
\text { no seu ápice. }\end{array}$ \\
\hline
\end{tabular}

Org.: Reginaldo J. Souza. Salientamos que a numeração das singularidades deu-se por uma simples questão de organização das informações visto que nosso objetivo não foi o de realizar um levantamento quantitativo das mesmas. Ademais, em seguida a este quadro, trataremos de uma representação fotográfica das informações aqui apresentadas. Cada um dos números (de 1 a 7) se prestarão para destacar estas singularidades nas imagens. 


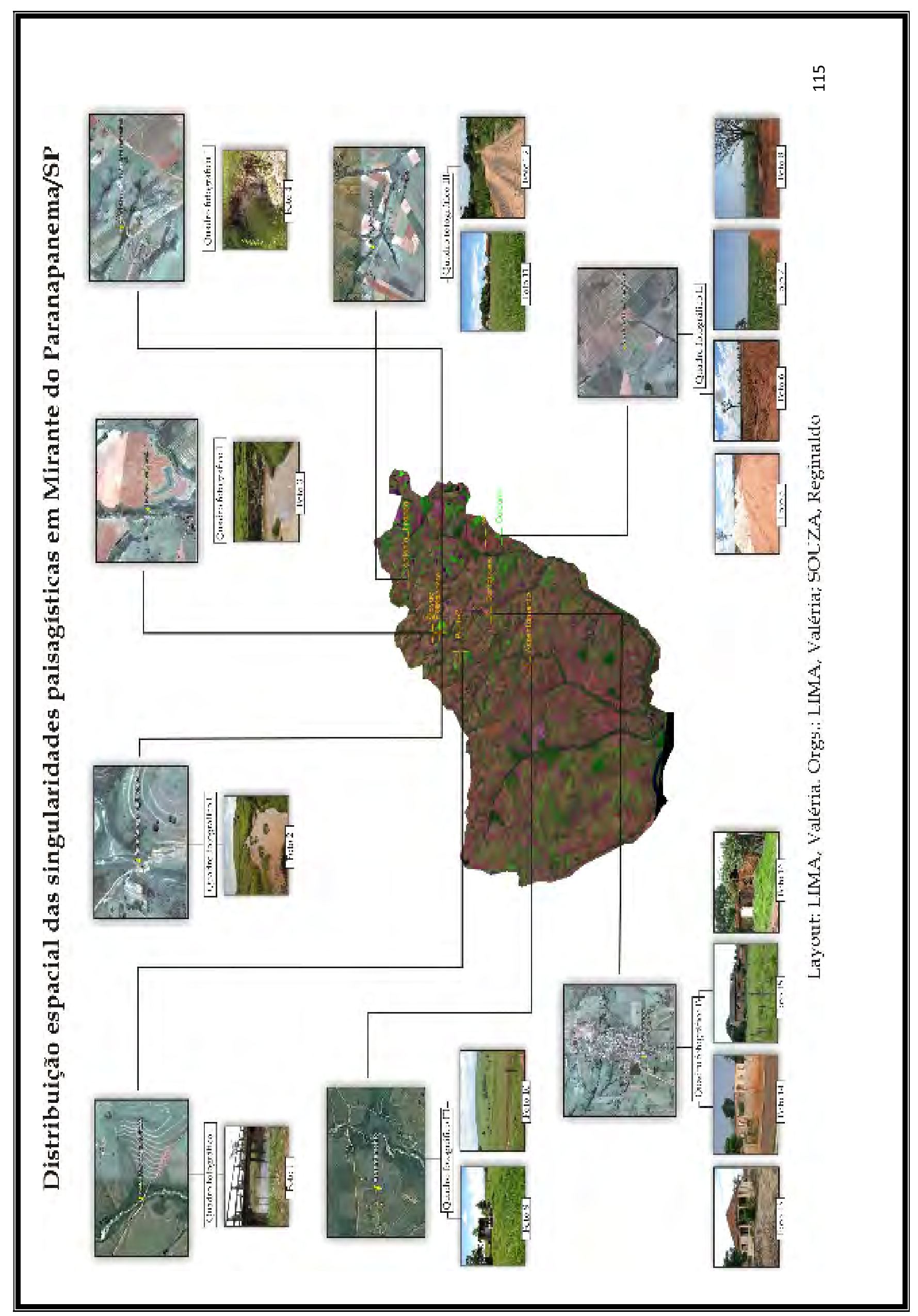




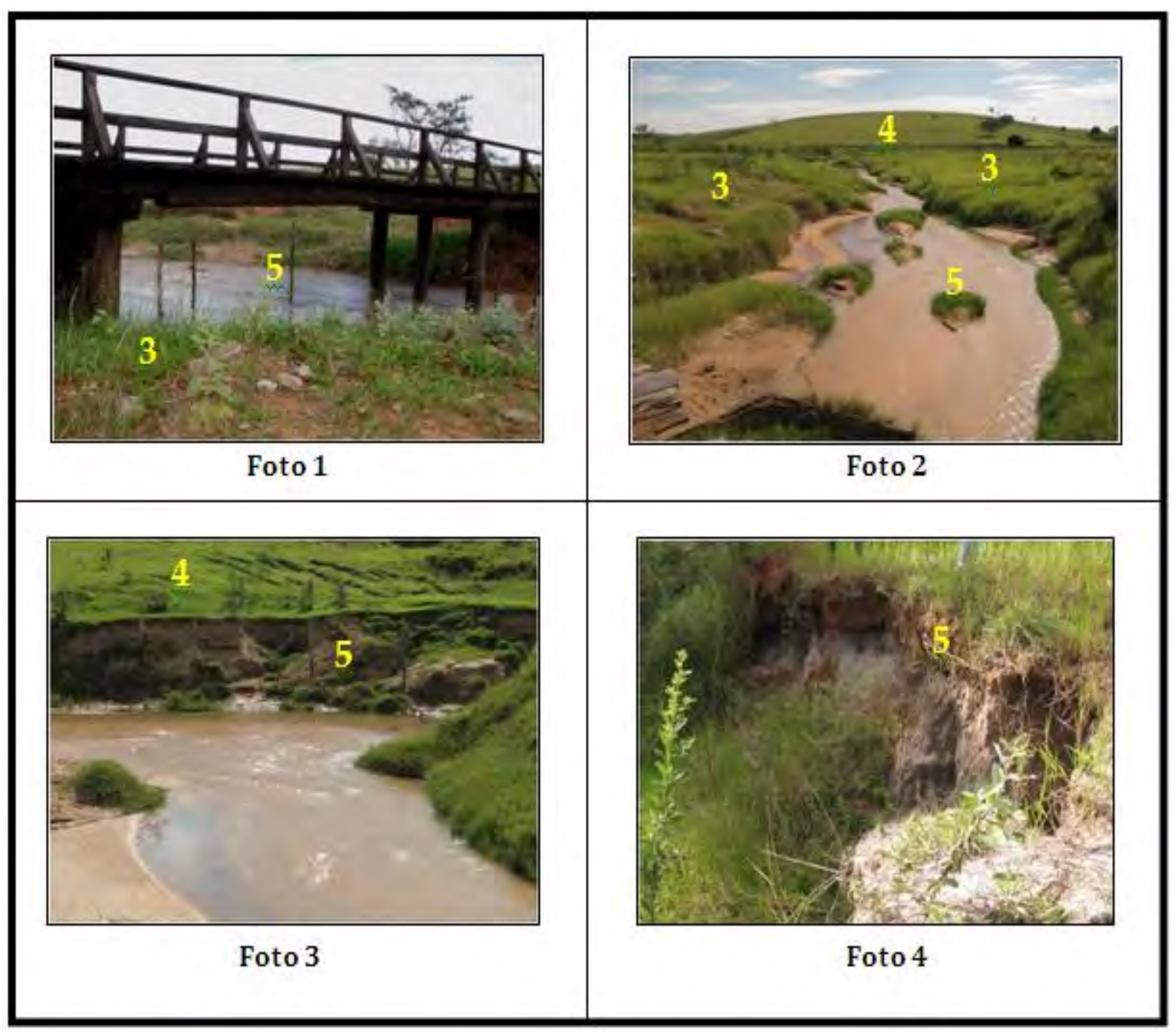

Quadro fotográfico I: Aspectos de ribeirões, margens e nascentes no município de Mirante do Paranapanema. A foto 1 ilustra o quadro de degradação e assoreamento do ribeirão Águas da Saúde cuja profundidade é cada vez menor possibilitando o encravamento de cercas de arame entre propriedades em pleno leito d'água (singularidade 5); agravando esta situação, observamos a total ausência de vegetação ciliar às margens deste ribeirão (singularidade 3). A foto 2 nos permite visualizar a total ausência de vegetação ciliar - e nas vertentes - com potencialidade para impedir ou diminuir a velocidade de escoamento das águas pluviais e, conseqüentemente, dos processos erosivos que transportam sedimentos para o curso d'água (singularidades 3 e 4); afloram-se bancos de areia no leito do ribeirão conferindo-lhe aspecto relativamente anastomosado; esta imagem foi obtida no alto curso do ribeirão Santo Antônio. A foto 3 também é referente a este ribeirão, nela destacamos (nunca é demais reforçar) a total ausência de vegetação na vertente e barrancos formados a partir de processos erosivos por solapamento (singularidade 5) que contribuem para agravar o quadro de assoreamento do rio. A foto 4 também revela este mesmo processo, porém, nas proximidades de uma das nascentes do ribeirão Santo Antônio. (Fonte das imagens: trabalhos de campo, 2008) 


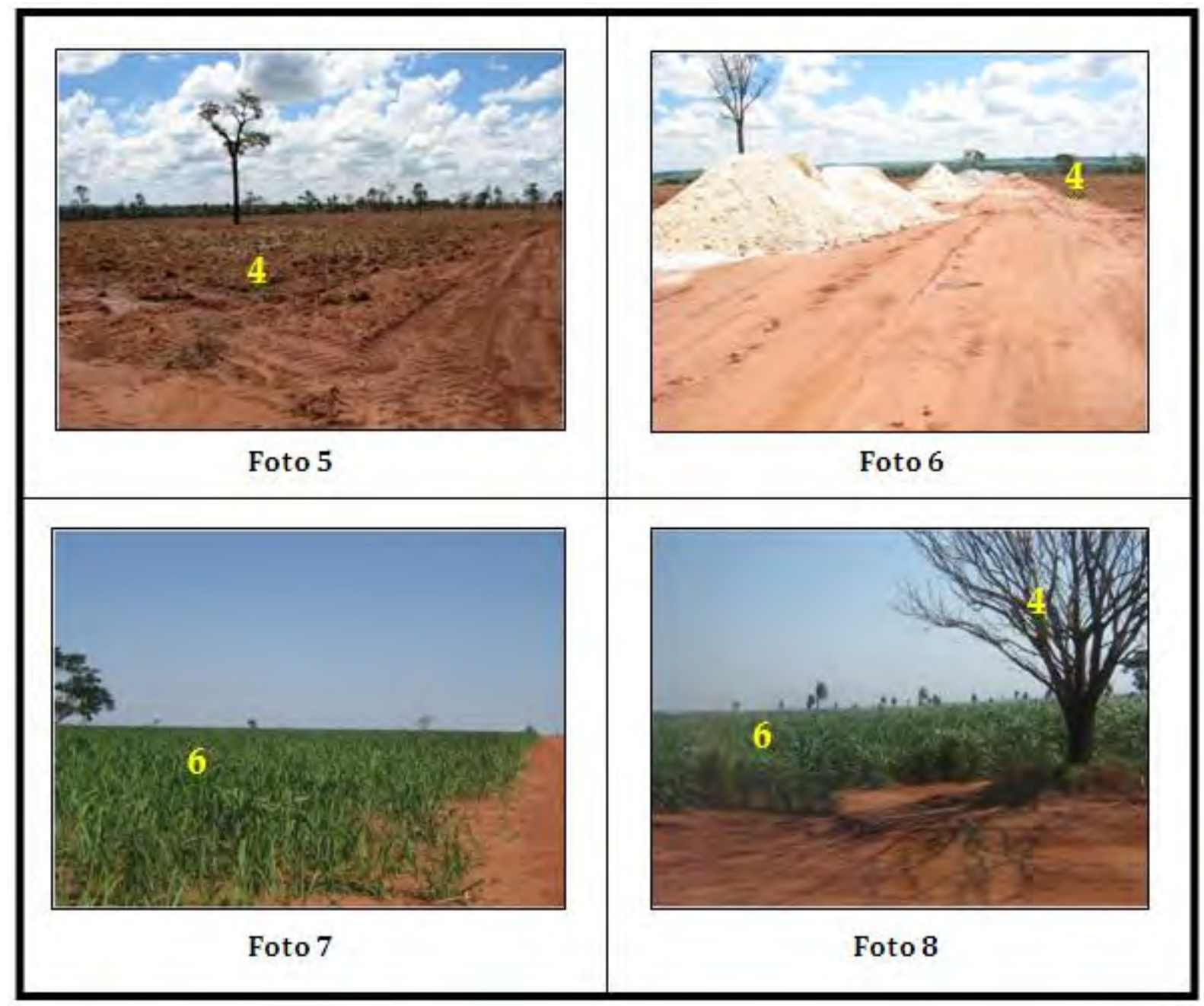

Quadro fotográfico II: Grande propriedade em Mirante do Paranapanema, antes e durante o plantio da cana-de-açúcar. Na foto 5 visualiza-se a extensão parcial de área na propriedade vistoriada por técnicos da Promotoria de Meio Ambiente de Presidente Prudente logo após uma denúncia por uso abusivo de agrotóxicos com envenenamento de significativa parte da Reserva Florestal Legal e Áreas de Preservação Permanente (singularidade 4). A foto 6 nos permite ver os depósitos de calcário, na propriedade, a ser utilizado para calagem do solo e posterior cultivo de cana-de-açúcar; é possível perceber que se trata de uma área com topografia plana que desperta grande interesse para se implantar este tipo de cultura que, certamente, exige mecanização. As fotos 7 e 8 foram obtidas cerca de seis meses depois de nossa primeira visita à propriedade (abril de 2008). Nestas imagens o plantio já está estabelecido sobre a área, porém, ainda convivendo com os traços da abrupta degradação gerada pelo uso de agrotóxicos anterior ao cultivo - a permanência da árvore em processo de secação (singularidade IV) é um icone do desmatamento cuja racionalidade está balizada pelo imediatismo dos interesses econômicos e contra a qual nem mesmo os rigores da legislação ambiental vigente são capazes de combater. (Fonte das imagens: trabalhos de campo, 2008) 


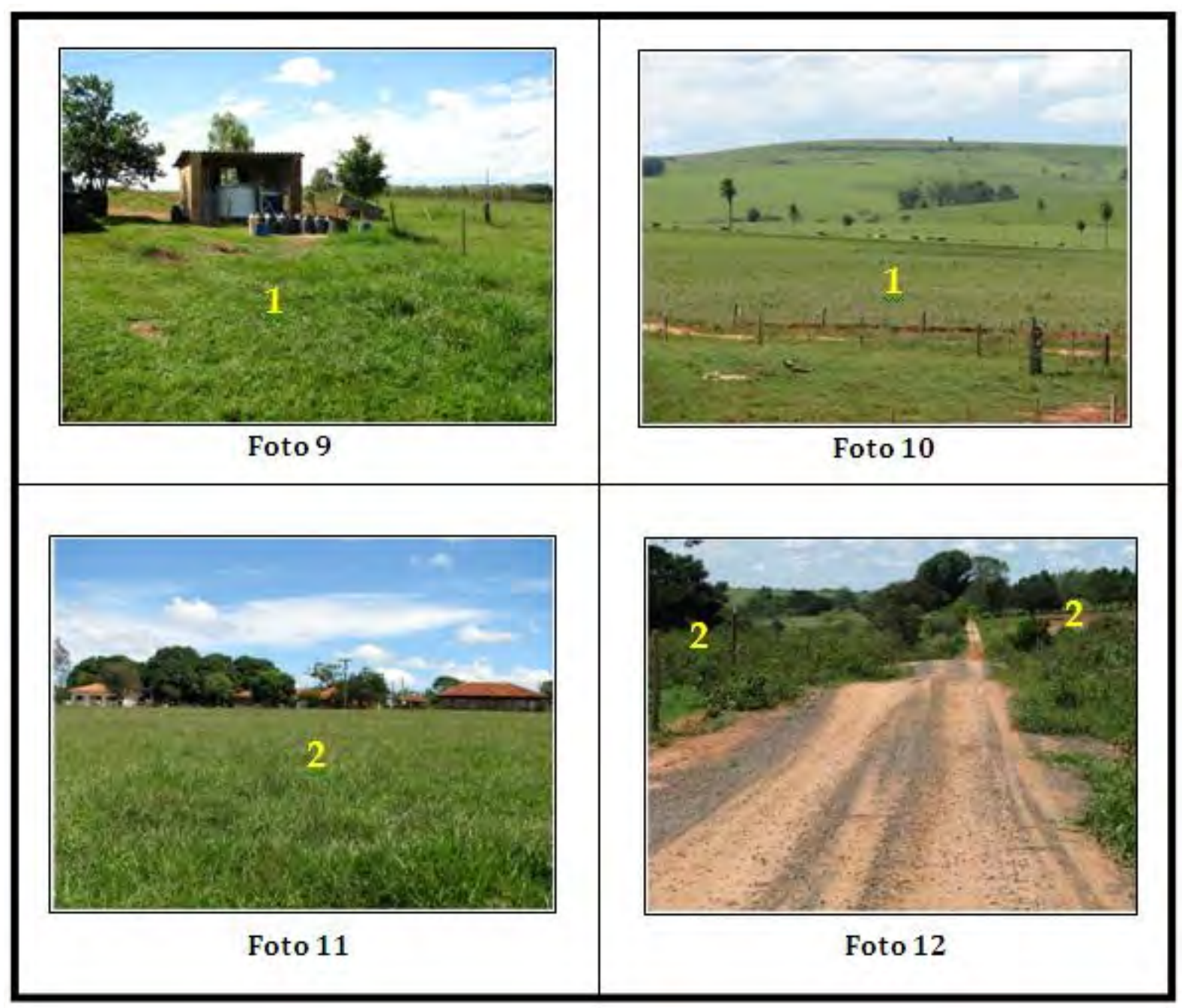

Quadro fotográfico III: Aspectos de assentamentos rurais de reforma agrária e do bairro rural Colônia Branca. As fotos 9 e $\mathbf{1 0}$ nos permitem visualizar áreas de assentamento de reforma agrária no município (singularidade 1). Na primeira se destaca um resfriador de leite no lote de um assentado que recebe (de modo cooperativista) a produção de toda sua vizinhança. O leite é comercializado para uma empresa de laticinios de Presidente Prudente. A pequena pecuária leiteira é a principal atividade econômica destes assentamentos onde, conforme um assentado entrevistado, os lucros são dependentes das variações climáticas (durante a estação seca, os preços da produção geralmente sofrem uma queda) e falta de melhores condições (apoio técnico e infra-estrutura) para melhorar a qualidade das pastagens. As fotos 11 e 12 correspondem ao bairro rural Colônia Branca contemplado pelo programa Microbacias Hidrográficas (singularidade 2). As ações no âmbito deste programa são exemplos visíveis de uma possível reversão de impactos socioambientais em Mirante do Paranapanema. Existe um trabalho de melhoria na conservação de estradas no intuito de favorecer os proprietários rurais, sobretudo no que diz respeito à diminuição dos processos erosivos ocasionados pelo escoamento superficial das águas pluviais. Neste bairro existem propriedades com pastagens de boa qualidade (com relação a outras áreas do município) e, por meio dos nossos trabalhos de campo, percebemos que eventualmente a agricultura de subsistência ou alguma pequena produção voltada para o mercado local coexiste com a pecuária leiteira. (Fonte das imagens: trabalhos de campo, 2008) 


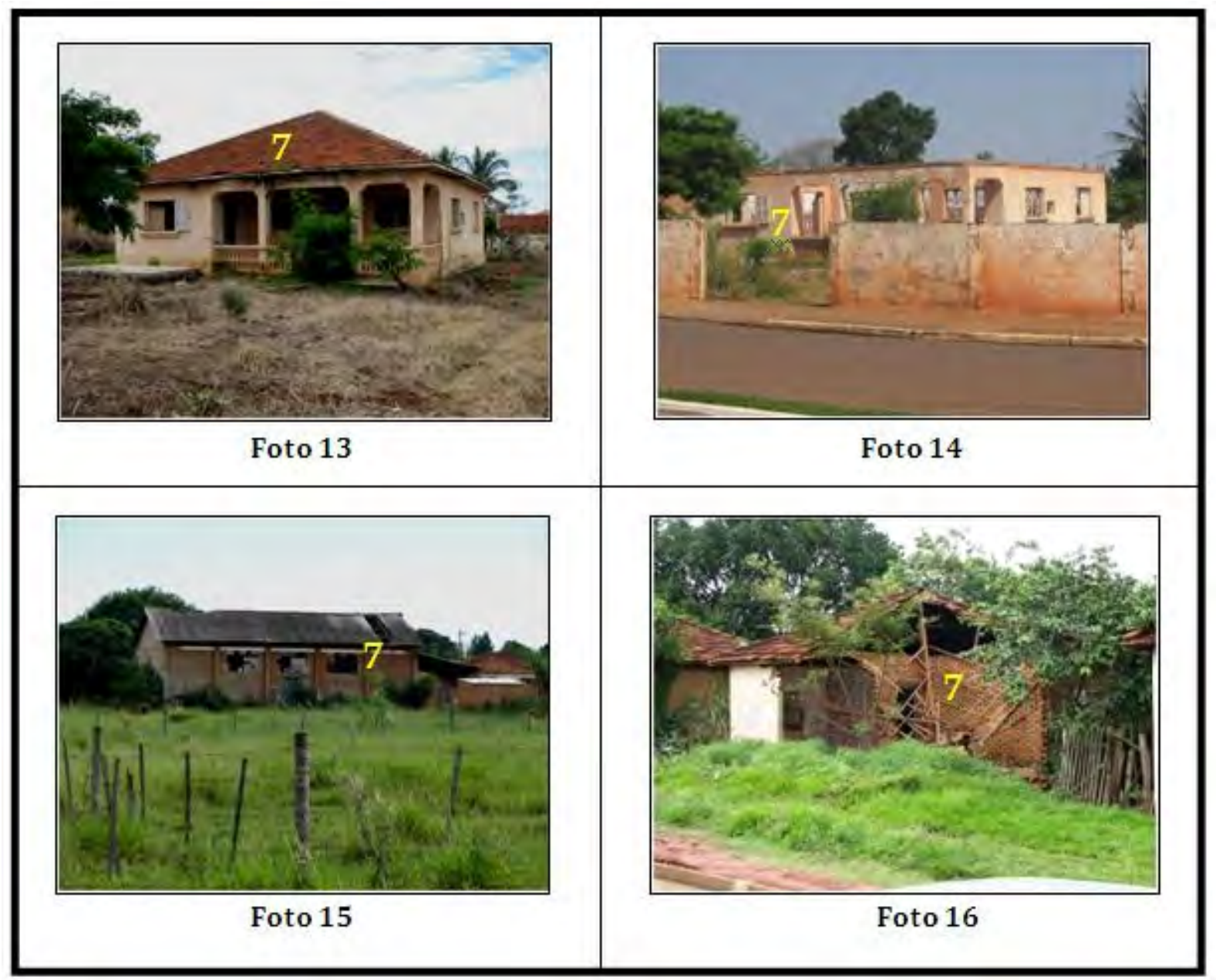

Quadro fotográfico IV: Ícones da desterritorialização (singularidade 7). As imagens nos remetem à decadência da lavoura (principalmente da cotonicultura) e expansão da pecuária entre as décadas de 1960 a 1980 em Mirante do Paranapanema. Interessante destacar aqui a dinamicidade da paisagem: as fotografias 13 e 14 são de uma antiga residência que, àquela época, era considerada de alto padrão e cuja propriedade era da beneficiadora SANBRA. Cerca de seis meses após a obtenção da primeira imagem (abril de 2008), nos deparamos com um quadro desolador de depredação do prédio. Igualmente surpreendentes são as condições de abandono no antigo barracão desta empresa (foto 15) bem como de um conjunto de antigas residências de seus funcionários (foto 16). Não nos compete fazer uma classificação do que deveria ser preservado como patrimônio histórico do município. Mas, acreditamos que o atual estado destes prédios reflete sobremaneira o "espírito" imediatista que guiou uma época onde a agricultura foi praticada intensamente e sem perspectivas futuras quanto à preservação ambiental. (Fonte das imagens: trabalhos de campo, 2008) 


\section{4) GTP: um filtro de linguagem ou chave conceitual para leitura das dinâmicas}

socioambientais em Mirante do Paranapanema

Anteriormente apresentamos as singularidades paisagísticas do município analisado. Tais singularidades são frutos de processos relacionados tanto à formação do território quanto à sua atual dinâmica socioeconômica. Consideramos interessante apresentar a processualidade que gerou a atual configuração da paisagem em Mirante do Paranapanema nos termos do sistema GTP como um filtro de linguagem ou chave conceitual que se presta para entrada na questão ambiental conforme descrevemos no capítulo referente ao nosso referencial teórico-metodológico.

Adentramos na leitura socioambiental deste território "abrindo" fatos por meio de cada um dos conceitos que integram o referido sistema teórico-metodológico sem perder de vista que os acontecimentos não ocorrem separadamente.

Partimos do processo inicial de ocupação histórica até o atual estado de baixa dinâmica territorial do município conforme se verificará nos próximos esquemas (10 ao 14).

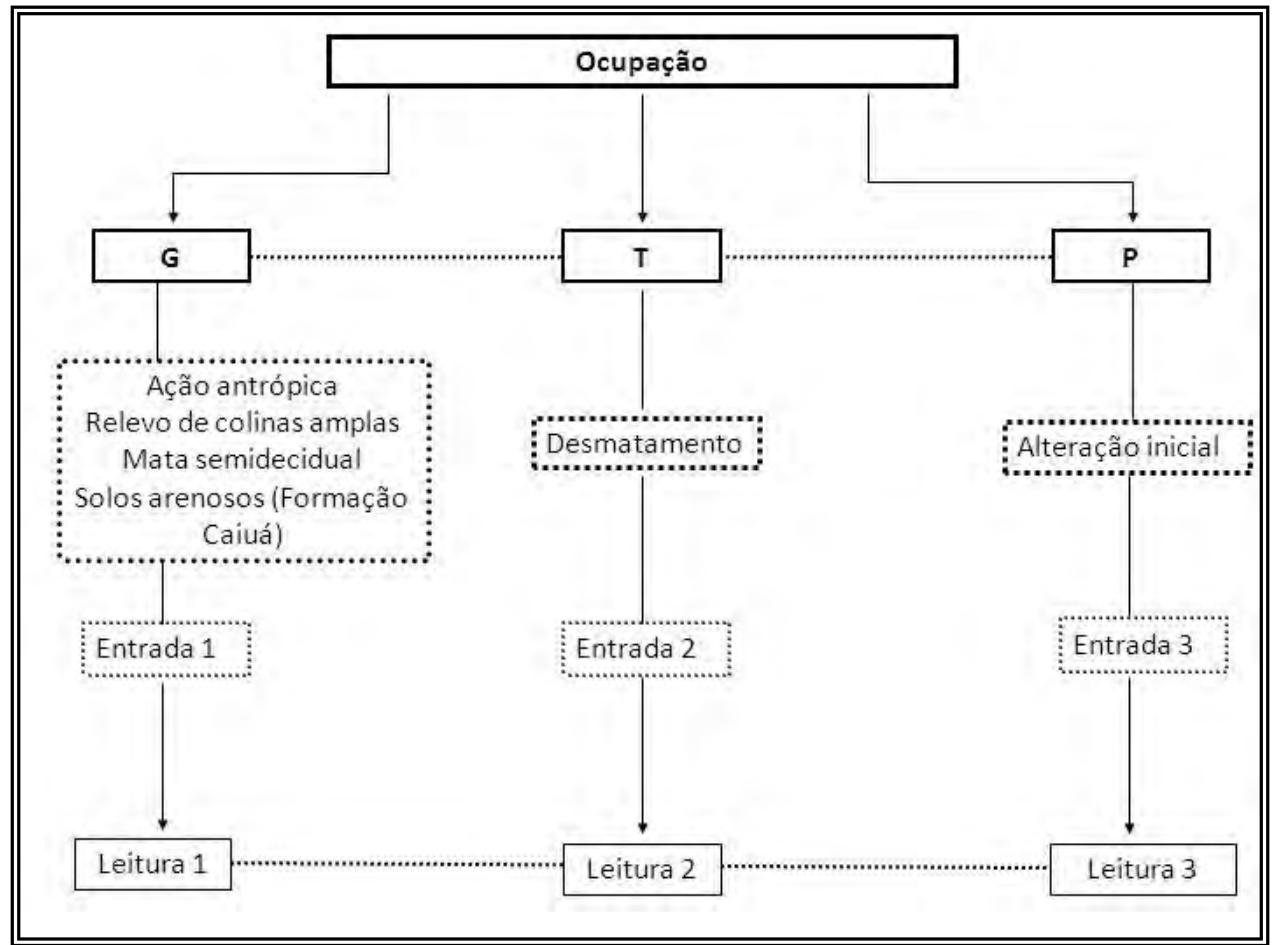

Esquema 10: "Leitura GTP" das dinâmicas socioambientais em Mirante do Paranapanema. "Ocupação" enquanto termo ou processo assume diferentes significados quando filtrado por cada um dos conceitos, ou seja, como ação antrópica sobre uma determinada configuração do potencial geoecológico; ações de desmatamento e alterações iniciais que culminaram no atual estado de degradação ambiental expresso pela paisagem do município. (Org. Reginaldo J. Souza) 
A ocupação do município (esquema 10, p.120) desde momentos anteriores a sua emancipação político-administrativa ocorreu sobre uma determinada configuração do potencial geoecológico com antigo predomínio da mata semidecidual, comum para toda região do Pontal do Paranapanema. A ocupação inicial esteve baseada nos desmatamentos (esquema 11) não apenas intensivos, mas também ostensivos porque este era uma forma de se garantir a posse da terra. $\mathrm{O}$ desmatamento deveria ter visibilidade. As atuais singularidades paisagísticas existentes em Mirante do Paranapanema germinaram neste momento de alterações iniciais.

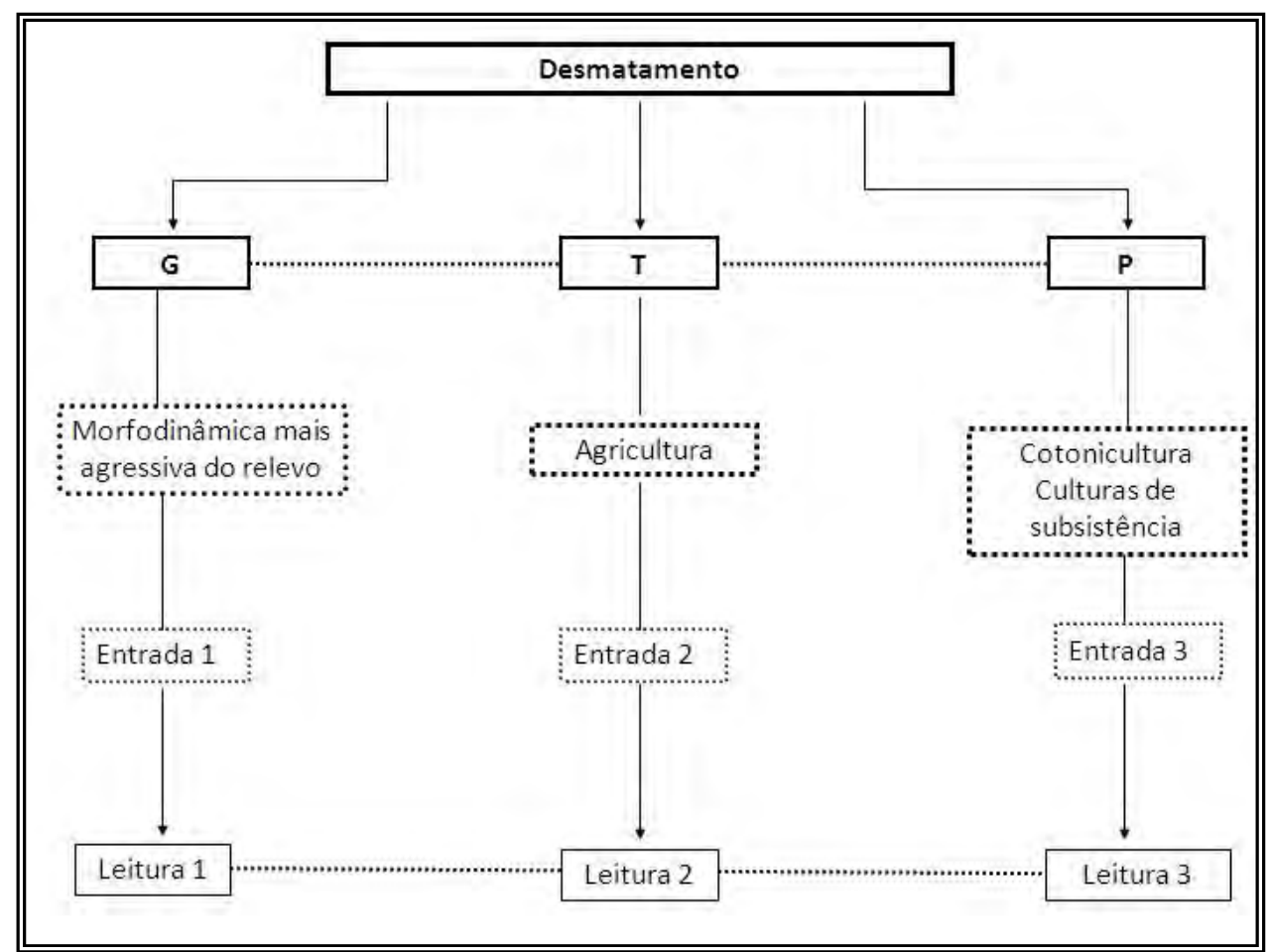

Esquema 11: “Leitura GTP" das dinâmicas socioambientais em Mirante do Paranapanema. "Desmatamento" enquanto termo ou processo assume diferentes significados quando filtrado por cada um dos conceitos. Levou a uma morfodinâmica mais agressiva do relevo, ao passo que as áreas desmatadas foram utilizadas para cultivo do algodão ou culturas de subsistência no município. (Org. Reginaldo J. Souza)

Portanto, as alterações iniciais estiveram diretamente vinculadas aos desmatamentos. Passando o desmatamento pelo filtro conceitual, ele se desdobra em alguns outros fatos. Ou seja, levou à morfodinâmica mais agressiva do relevo com proeminentes processos erosivos agravados pela implantação da atividade agrícola (esquema 12, p.122) cujas principais culturas foram o algodão (Mirante do 
Paranapanema era cunhada como a "capital do ouro branco" na década de 1950) e o amendoim - elementos que se destacavam na paisagem.

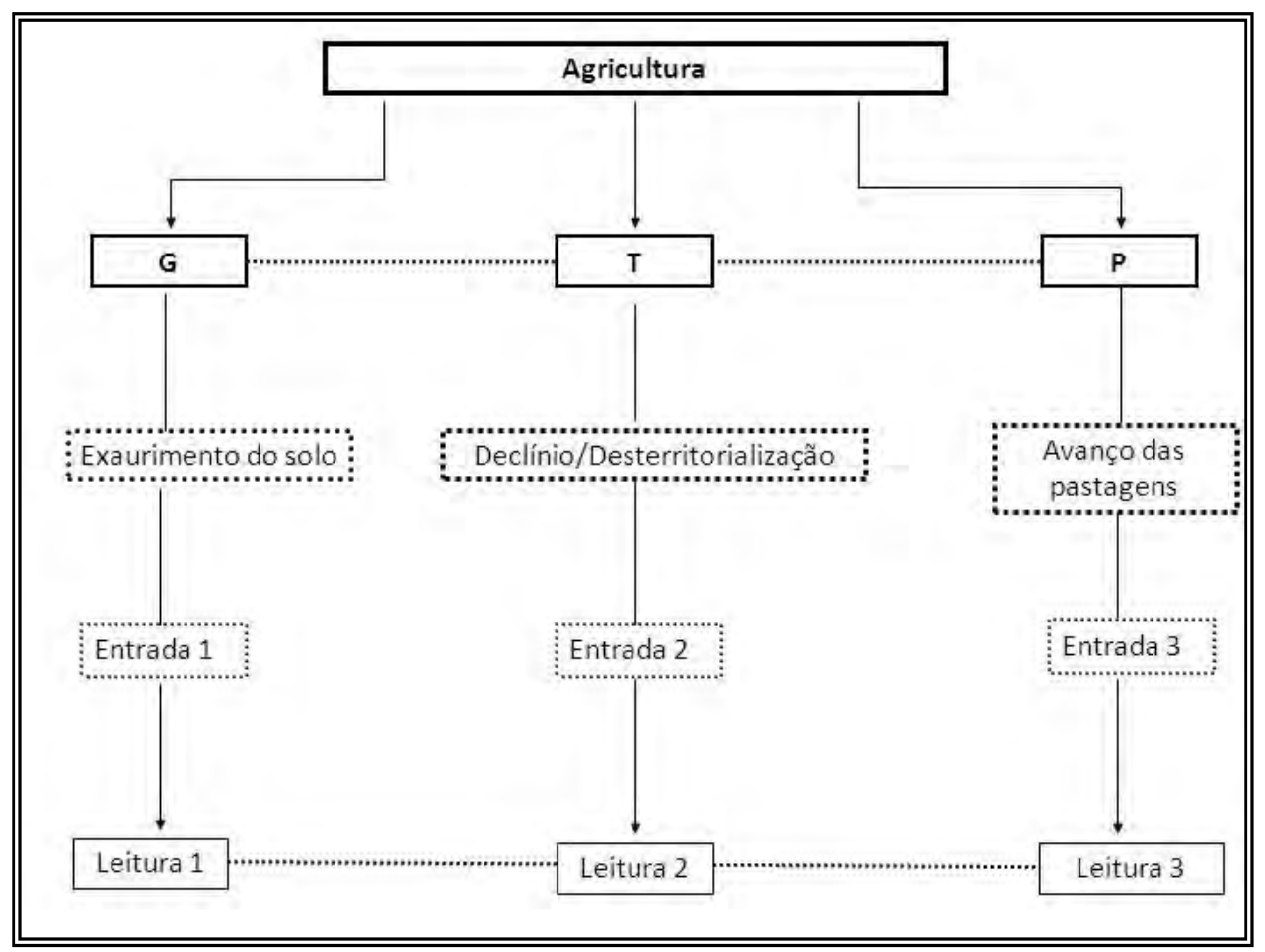

Esquema 12: "Leitura GTP" das dinâmicas socioambientais em Mirante do Paranapanema. O exaurimento do solo no município é visualizado como desdobramento negativo da/à agricultura implantada desde sua fundação. Como o empobrecimento do solo foi um dos fatores decisivos ao declínio da atividade, o processo de desterritorialização caracterizou a dinâmica populacional de Mirante e as antigas áreas de lavouras deram lugar às pastagens - que possuem significativo destaque na paisagem do município atualmente. (Org. Reginaldo J. Souza)

A agricultura teve um importante papel no contexto econômico do município no passado (entre as décadas de 1940 e 1960, principalmente), porém as práticas agrícolas foram bastante predatórias e levaram ao franco exaurimento do solo (cujas características físico-químicas não são das mais propícias a cultivos sem manejo adequado). A primeira conseqüência negativa deste fato é a própria barreira à continuidade da atividade. A dinâmica do território, com o declínio agrícola, foi marcada pela saída de empresas beneficiadoras do município e deslocamentos populacionais do campo para a cidade (ver esquema 2, pg. 22). As lavouras passaram a perder espaço para a atividade pecuária. $\mathrm{O}$ avanço das pastagens marca a estética paisagística a partir deste momento (esquema 13, p.123). 


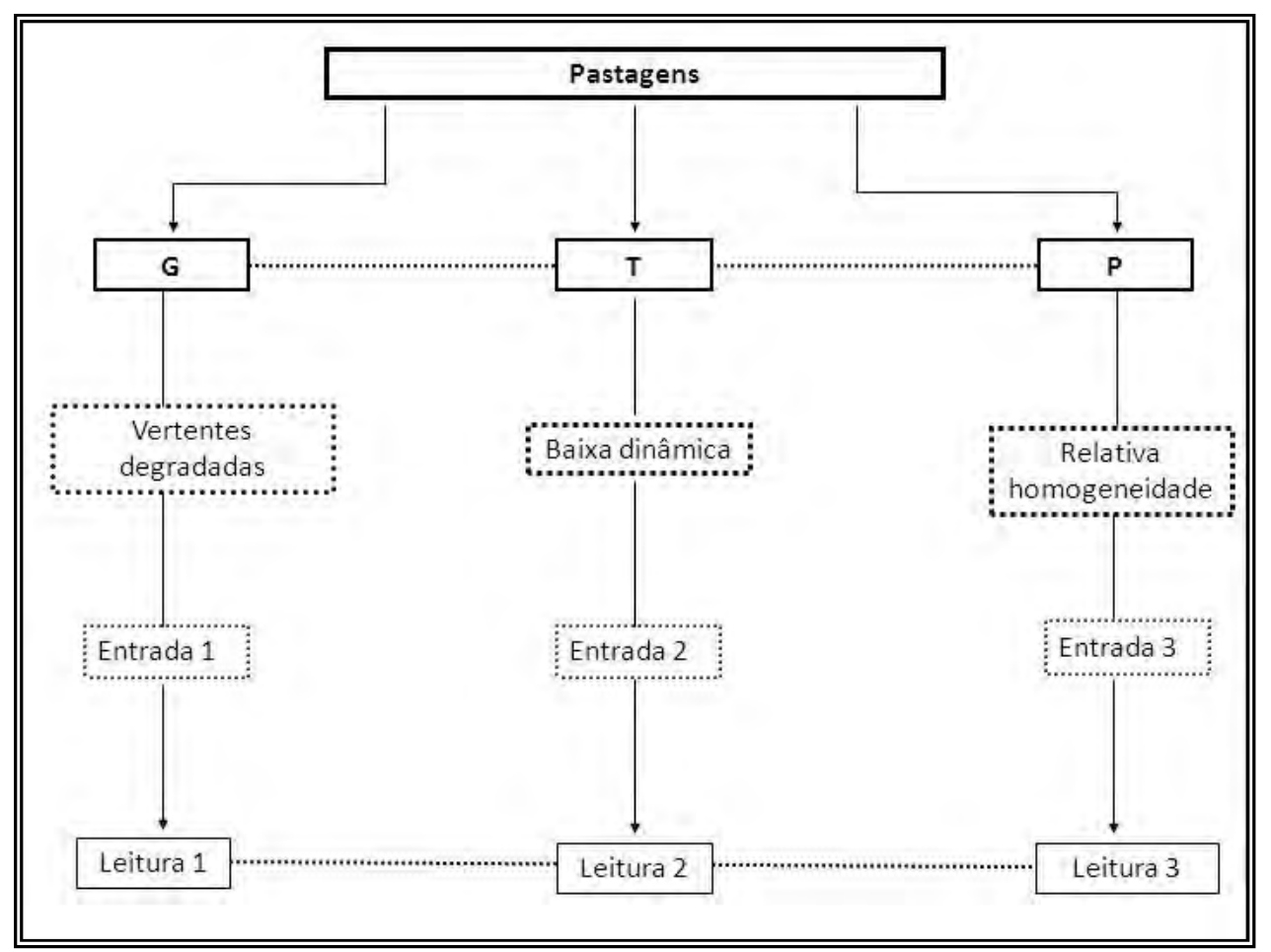

Esquema 13: "Leitura GTP" das dinâmicas socioambientais em Mirante do Paranapanema. Atualmente as áreas de pastagens contribuem significativamente ao processo de degradação das vertentes. Este tipo de atividade (pecuária leiteira) expõe a fragilidade econômica de Mirante do Paranapanema (as pastagens são pobres e sua capacidade de apascentamento é comprometida conforme os processos erosivos e assoreamento dos córregos avançam). As áreas de pastagens conferem relativo grau de homogeneidade fisionômica à paisagem. (Org. Reginaldo J. Souza)

As pastagens degradam as vertentes do topo até as margens dos ribeirões, inclusive desrespeitando até mesmo as Áreas de Preservação Permanente estabelecidas por lei. O território apresenta baixa dinâmica socioeconômica (esquema 14, p.124) porque a pecuária no município é pouco rentável e dependente dos baixos preços que são estabelecidos pelos laticínios aos produtores atualmente. A paisagem denota a relativa homogeneidade desta atividade e a agressão que causa ao ambiente.

Certamente podemos afirmar que a baixa dinâmica socioeconômica do território influencia e é influenciada pela degradação ambiental. A consciência a respeito desta relação pode levar à implantação de atividades que visem minimizar os impactos e reverter alguns problemas. Ou não.

No caso de Mirante do Paranapanema, a baixa dinâmica socioeconômica desperta gestores municipais para tomada de medidas mitigatórias, sobretudo no 
âmbito do programa Microbacias Hidrográficas em que verbas são destinadas para que proprietários rurais cerquem Áreas de Preservação Permanente (de modo a impedir a passagem do gado) ou façam curvas de nível para diminuir a proeminência dos processos erosivos.

Infelizmente estas medidas ainda não são tomadas de maneira integrada. Existem descontinuidades em detrimento de ações conjuntas. Uma determinada propriedade pode possuir curvas de nível nas vertentes, mas a propriedade vizinha não. Este foi um exemplo que pudemos verificar em um dos nossos trabalhos de campo.

Teoricamente, a baixa dinâmica socioeconômica do município deveria abrir possibilidades ao estabelecimento de atividades em moldes totalmente contrários aos que existem hoje e que, tanto o passado quanto a atualidade comprovam isso, são extremamente degradantes tanto do ponto de vista social quanto ambiental.

Porém, não é exatamente isso o que acontece em Mirante do Paranapanema. Traduzamos esta questão pelo filtro GTP:

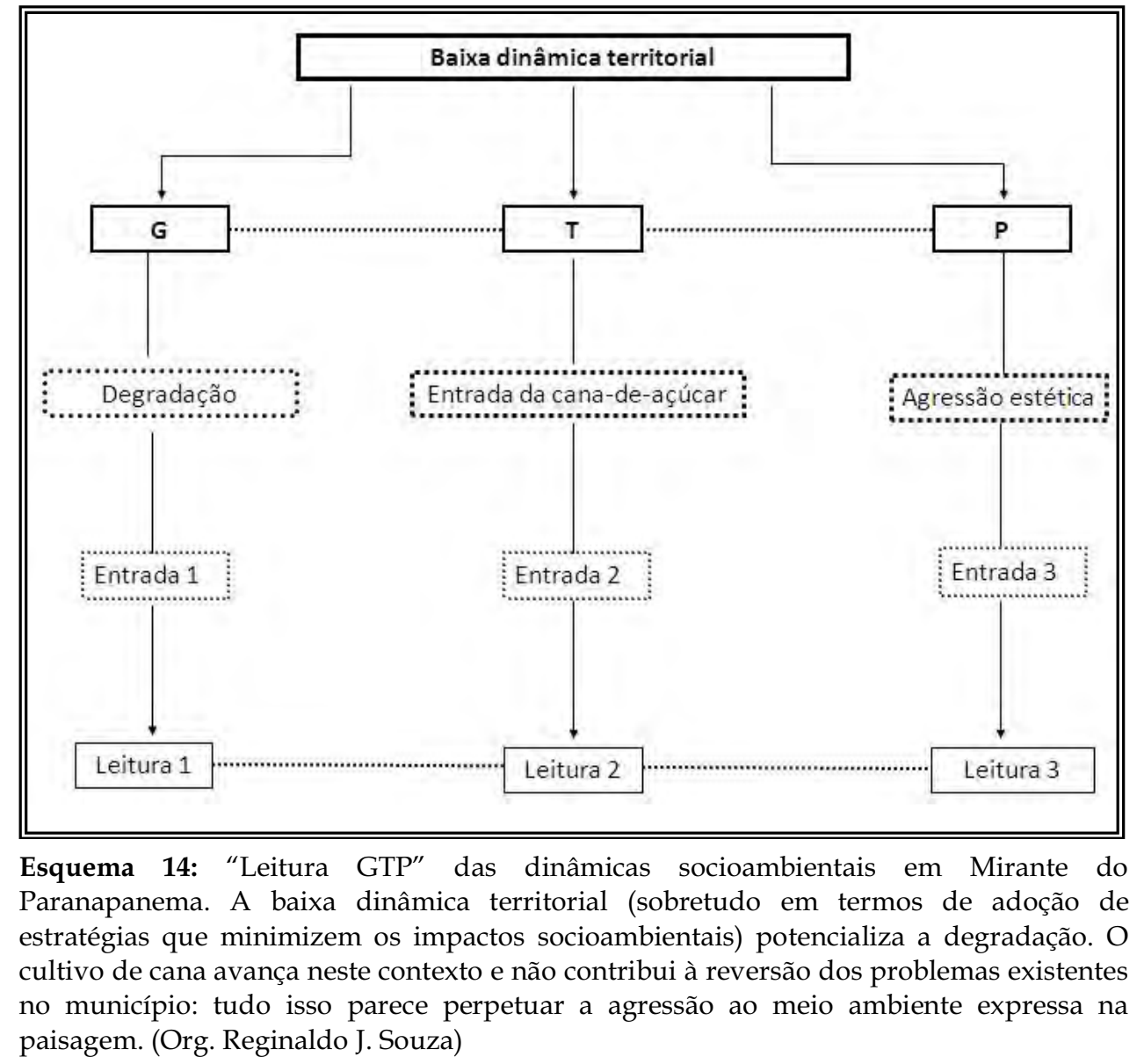


A baixa dinâmica territorial efetiva a permanência da degradação do potencial geoecológico. As possibilidades de implantação de atividades menos predatórias tornam-se quase utópicas perante a entrada da produção de cana-de-açúcar no município: um elemento cada vez mais presente na paisagem atual e que, certamente, também contribui e contribuirá ao aprofundamento dos impactos socioambientais e, conseqüentemente, da agressão estética à paisagem.

\section{5) Algumas considerações}

A partir da premissa de que a paisagem é fruto de uma determinada configuração territorial, foi possível identificar uma série de elementos na área de estudo que possibilitaram as nossas reflexões e a produção deste capítulo.

Entendemos como dinâmicas socioambientais as relações que a sociedade estabelece com seu ambiente ao passo que transfigura seus elementos geoecológicos em recursos necessários à produção e reprodução do território em escalas de curto, médio e longo prazo.

É a partir deste instante que as dinâmicas socioambientais podem tomar diferentes aspectos e proporções. Elas podem se traduzir (utopicamente, talvez) em relações mais harmoniosas entre homem e meio ou tomar dimensões negativas, traduzindo-se como verdadeiros impactos que prejudicam tanto o homem quanto a natureza.

Em Mirante do Paranapanema existem problemas referentes a empobrecimento do solo, processos erosivos e assoreamento de ribeirões. A gravidade desta problemática é evidente e fruto de uma cultura estabelecida (uso irracional dos potenciais geoecológicos, baseado em interesses econômicos imediatos) desde a ocupação histórica do Pontal do Paranapanema. As dinâmicas socioambientais neste município tomaram feições de impactos...

Então, a análise de qual aspecto deve ser priorizada? Da desobediência aos princípios da legislação ambiental? Da carga de sedimentos que os ribeirões vêm recebendo das vertentes contribuindo para o assoreamento? Da baixa capacidade 
produtiva das pequenas propriedades ou dos assentamentos rurais? Da relação de causa e efeito entre degradação ambiental e economia pouco dinâmica e capaz de potencializar o desenvolvimento local? Todos os aspectos devem ser considerados.

A abordagem do meio ambiente é, no mínimo, complexa. Então, novamente salientamos nossa inclinação ao referencial teórico-metodológico bertrandiano. Certamente o sistema GTP abre a possibilidade de leitura mais abrangente da temática do meio ambiente territorializado.

Neste capítulo expusemos nossa abordagem sobre as dinâmicas socioambientais em Mirante do Paranapanema procurando não setorizar os fatos observados em um prisma exclusivamente naturalista (dos elementos físicos da paisagem e suas dinâmicas em si) ou exclusivamente social (de um "território sem terra" (BERTRAND, 2007, p.187), ou seja, totalmente desligado de sua dimensão física-natural).

O sistema GTP permitiu/permite uma varredura conceitual que nos remeteu/remete direta e indiretamente, imediata e mediatamente, esquemática e complexamente à realidade. A partir de nossas reflexões sobre este referencial, podemos considerar que:

i) O geossistema aparece como um a priori da ação humana, isto é, a fonte (source) conforme colocado por Georges Bertrand (2007). E o nosso objetivo não se deteve a esmiuçar todos os aspectos das dinâmicas "naturais" dos elementos físicos da paisagem porque é imprescindível visualizar as interfaces (1-sociedade/2-economia/3-cultura e 1-natureza/2-recurso/3-representação) dos fenômenos.

ii) O potencial geoecológico presente no município (relevo de colinas amplas, formações do Grupo Bauru, solos arenosos, antigo predomínio da mata semidecidual) foi uma fonte trasladada em recurso a partir da ocupação do território até os dias atuais.

O potencial geoecológico não é mais tão natural em Mirante do Paranapanema. Sua apropriação inadequada levou ao declínio de lavouras que foram relativamente prósperas no passado; trouxe o aumento do número de pastagens pouco desenvolvidas no presente; abrirá possibilidade à hegemonia do cultivo de cana-de-açúcar no futuro? 
O potencial geoecológico é alvo de aspirações e olhares carregados de diferentes racionalidades, diferentes ideologias. Exemplos muito interessantes são expostos, a seguir, por meio de trechos do Relatório de Impacto Ambiental referente à ampliação da Usina Conquista do Pontal, no município, e do parecer técnico de vistoria realizada em uma determinada fazenda por técnicos do Ministério Público do Estado de São Paulo.

\begin{abstract}
A ampliação da usina foi planejada com o objetivo de atender às necessidades do empreendimento, bem como às demandas do mercado. As modificações produzirão impactos positivos na economia regional, pelo aumento na arrecadação de impostos, os quais futuramente irão refletir diretamente na arrecadação do município de Mirante do Paranapanema. Portanto, o aumento da arrecadação de tributos gerado com a ampliação do empreendimento promoverá maior desenvolvimento da economia local e regional, que será responsável, entre outras coisas, pela melhoria dos serviços básicos oferecidos à população.

Pelo exposto, pode-se concluir que o balanço ambiental geral do empreendimento é positivo. Em termos de impacto socioeconômico e ambiental, o aumento da capacidade de produção da usina causaria pouca mudança na forma de ocupação do solo, uma vez que a lavoura de cana já se encontra em boa parte das terras da região. Não haverá expansão de lavoura em área de mata.

A cana-de-açúcar plantada nas novas áreas será cortada sem utilização de queimadas, conforme o estabelecido na legislação vigente, o que traz ganho ambiental local, e conseqüentemente, a mitigação de impactos futuros, decorrentes de efeito cumulativo, em virtude do funcionamento de outras usinas na região. (Relatório de Impacto Ambiental - RIMA para ampliação da Usina Conquista do Pontal, 2008, p.18, grifo nosso)
\end{abstract}

No parecer técnico da vistoria na fazenda localizada entre os municípios de Mirante do Paranapanema e Presidente Bernardes, a partir de denúncia sobre degradação ambiental na propriedade, há as seguintes constatações:

1. Na propriedade o solo vem sendo preparado para receber o plantio de cana-de-açúcar. [...]

6. As áreas de preservação permanente da propriedade estão parcialmente ocupadas com o pastoreio de animais e degradadas pelo uso intensivo com desmatamento e plantio de gramíneas artificiais para pastoreio de animais. (Parecer Técnico - Procuradoria Geral de Justiça Centro de Apoio Operacional das Promotorias de Justiça de Urbanismo e Meio Ambiente - Área Regional de Presidente Prudente, 2008, p.5, grifo nosso) 
Certamente os textos não possuem relações diretas entre si, ao contrário, suas finalidades são bastante distintas. Expusemos os mesmos porque são representativos dos diferentes olhares e aspirações que incidem sobre o potencial geoecológico do município. O RIMA conclui que o empreendimento da usina de cana terá repercussões locais e regionais positivas e sem a expansão das áreas cultivadas para as áreas de mata.

Por outro lado, as constatações no parecer do Ministério Público nos remetem à voracidade do desmatamento com vistas ao plantio de cana e formação de pastagens. Em trabalhos de campo, verificamos que o plantio da cana é predominante naquela fazenda (conforme quadro fotográfico II, pg.117). Ou seja, os acontecimentos podem tomar proporções imprevisíveis: entre as ideologias que são difundidas e as práticas, de fato, existentes.

A construção da paisagem, em Mirante do Paranapanema, é caracterizada por tais incoerências. A exploração econômica do/no território não obedece, muitas vezes, os limites que deveria ter e nem mesmo aqueles que são estabelecidos por leis. Os resultados negativos destas relações são evidentes: singularidades paisagísticas que denotam as carências do município no que tange à ausência de práticas agropecuárias menos predatórias e maiores incentivos para difusão, estabelecimento e integração dos projetos que estimulam o desenvolvimento local.

\section{$\operatorname{son}$}

Antes de passarmos ao próximo capítulo, gostaríamos de lembrar ao leitor que Georges Bertrand nos fala de dois subconjuntos que compõem o modelo de interpretação da paisagem que devemos considerar em nossas análises:

- um subsistema "cultural" baseado nas percepções e representações paisagísticas que deve revelar a diversidade e de cruzamento dos olhares sobre um mesmo território. Ele permite, em particular, evidenciar as questões, as contradições e os conflitos que nascem em torno da paisagem. Os olhares não são todos iguais; eles se hierarquizam em função de um modelo dominante fortemente mediatizado. 
- um subsistema material que propõe uma análise dos objetos da paisagem, com suas características biológicas ou físicas, sua organização espacial e seu funcionamento histórico.

A confrontação permanente entre estes dois subsistemas, com diferentes escalas de tempo e de espaço, permite analisar a sinergia do complexo paisagístico e evidenciar as disfunções internas, retroações, inércias e defasagens, que caracterizam toda a paisagem. (BERTRAND, 2007, p.254, grifo nosso)

Assim, podemos apreender as dinâmicas socioambientais por dois critérios complementares:

- O primeiro diz respeito aos aspectos materiais: impactos expressos por singularidades paisagísticas diretamente observáveis no território. A elaboração do capítulo que agora encerramos foi norteada por este critério.

- O outro é referente à dimensão imaterial da relação homem-meio. Existem certos elementos que não são imediatamente observados na paisagem: a maneira pela qual um indivíduo apreende seu espaço de vivência, por exemplo. Esta dimensão também deve ser considerada no âmbito da proposta GTP, conforme apresentaremos no próximo capítulo. 


\section{Capítulo V: \\ A bacia do ribeirão Santo Antônio na perspectiva dos seus moradores}




\section{soce}

"Passar pela paisagem é, para o pesquisador, um percurso perigoso. Ele é, entretanto, necessário para fornecer esta dimensão humana, social e cultural, em uma palavra, cidadã, freqüentemente ausente das questões de meio ambiente e da transformação do território. Ele nos incita a pensar no nosso futuro que é também aquele de nossos terroirs, de nossos territórios, de nossa Terra".

(Georges Bertrand)

8003 


\section{1) Notas introdutórias}

Por meio de nossas pesquisas de campo, depreendemos os reflexos negativos sobre a população local - de uma relação dissimétrica entre sociedade e meio ambiente no município estudado.

Uma das abordagens em voga na ciência geográfica diz respeito à percepção do indivíduo sobre seu espaço de vida. A análise dos diferentes modos de captação da e reação à paisagem pelas pessoas em sua vida quotidiana também é um importante elemento para aprofundar o conhecimento sobre as dinâmicas socioambientais em um dado território.

A abordagem sobre as dinâmicas socioambientais por meio do sistema GTP nos leva ao encontro da "complexidade vivida do quotidiano" (BERTRAND, 2007, p.233) e sua importância para a análise da paisagem.

Neste capítulo, trataremos de alguns aspectos referentes às formas de apreensão da paisagem por moradores da alta bacia do ribeirão Santo Antônio a partir de entrevistas semidirigidas que realizamos na área. Mas, antes disso, apresentaremos as nuances teóricas (além da abordagem bertrandiana propriamente dita) que conduziram as entrevistas e as análises em si.

2) Meio ambiente, suas paisagens e seus atores: possibilidades de análise a partir da experiência quotidiana

Afirmamos que o meio ambiente pode/deve ser trabalhado por meio de categorias como território ou paisagem. Certamente é possível dizer que estas categorias assumem papéis cada vez mais centrais no âmbito da Geografia, contribuindo de modo significativo para a evolução do pensamento em torno da disciplina como um todo. Já que oferecem um salto qualitativo em termos epistemológicos ao discurso geográfico, conseqüentemente se prestam como "chaves" 42 para entrada na questão ambiental.

42 Tratamos deste assunto no capítulo II ao nos referirmos sobre o sistema GTP como um filtro de linguagem ou chave conceitual para entrada na questão ambiental. 
Dematteis (2007, p.7), por exemplo, fazendo referência à importância da abordagem territorial na Geografia, nos lembra que as concepções territorialistas mais recentes "absorvem e reelaboram as diferentes concepções da geografia do passado: como ciência da diferenciação do espaço terrestre, ciência das relações multiescalares entre o ambiente físico e a sociedade humana, ciência da paisagem e assim por diante". (grifo nosso)

Recentemente, sobretudo com a emergência e intensidade da problemática ambiental, a Geografia vem se preocupando cada vez mais com a construção de um conhecimento mais profundo sobre a relação da sociedade com a natureza, entre os homens e seu (s) meio (s) ambiente (s), considerando-se que o homem é promotor de profundas transformações da natureza pela via do sistema econômico, político e cultural em que se organiza.

Neste sentido, compreendemos que deve ser do interesse do geógrafo analisar a problemática ambiental de forma integrada, onde a natureza não seja encarada de maneira compartimentada e enquanto sinônimo de ecossistema regido por leis exclusivamente naturais. É preciso ir além de certas concepções.

Segundo Bertrand:

O meio ambiente é, antes de tudo, um imenso questionamento, global e confuso, quase metafísico, que a sociedade faz a si mesma e, mais precisamente, ao conjunto da comunidade científica. O meio ambiente é, em resumo, o que sobra quando as diferentes ciências não esqueceram nada em seus respectivos domínios, ou seja, todas as interconexões, e mais precisamente aquelas que fazem interagir os fatos naturais e os fatos sociais. Enfim, trata-se menos de uma ciência do que de uma consciência, coletiva e multiforme, à qual cada disciplina é obrigada a responder sob pena de desqualificação. $(2007$, p.84)

Na concepção do autor mencionado, a ciência geográfica está bem situada no que diz respeito às respostas aos desafios que emergem da questão ambiental. (Cf. BERTRAND, 2007, p.84) Porém, isso não deve ser interpretado de modo comodista ou algo do tipo. O tratamento geográfico do meio ambiente ainda apresenta uma série de lacunas, ou "caixas pretas", que devem ser preenchidas e superadas. 
Uma destas lacunas diz respeito à necessidade de se trabalhar com o meio ambiente tendo-se como princípio considerar os cenários prospectivos; afinal, "não podemos trabalhar com o meio ambiente sem pensar no futuro, imediato ou distante [...]". (BERTRAND, 2007, p.89). Ao geógrafo cabe estar atento ao aménagement do território, ou dos territórios. (p.285)

Referindo-se ao meio ambiente sob a perspectiva territorial, Bertrand (2007) nos remete a importância da análise paisagística. De um reencontro entre paisagem e Geografia e sua importância para a análise ambiental, sobretudo em termos de políticas de ordenamento do território.

O que há de mais interessante nesta abordagem é o fato de sermos levados a pensar nestas questões de ordenamento territorial não apenas pelo viés institucional: dos gestores municipais, estaduais ou federais (no caso brasileiro, por exemplo). A paisagem, como representação sociocultural, nos permite reintroduzir "o indivíduo, e sua sensibilidade, no processo social". (BERTRAND, 2007, p.88)

A recente consideração do meio ambiente, polarizada na urgência dos problemas de despoluição e de tratamento do lixo, preocupou-se pouco com as paisagens e aquilo que elas representam para as populações envolvidas.

[...] as mentalidades e os comportamentos dos cidadãos estão em plena evolução. Novos valores e novas necessidades aparecem [...]. Aparece uma verdadeira mutação da sensibilidade que atinge nossas relações com o patrimônio e o território. (BERTRAND, 2007, p.286)

Existem perspectivas de análise na Geografia que consideram a relação entre planejamento e gestão participada da paisagem (PINTO et. al., 2009). Isto significa, entre outros fatores, a importância cada vez maior que a dimensão da paisagem (como representação sociocultural) vem tomando no âmbito dos estudos territoriais ao passo que o território pode ser tido como "[...] um espaço natural, social e historicamente organizado e produzido" e a paisagem como o "[...] nível do visível e percebido deste processo". (SAQUET, 2007, p.142 refletindo a respeito da obra de TURRI, 2002). Sendo assim, entendemos a relevância destas categorias para a análise geográfica do meio ambiente territorializado e, também, representado e percebido. 
Ainda a respeito da paisagem, Santos (1997, p.61) a define como tudo aquilo que nós vemos, podendo ser tomada como o domínio do visível e formada não apenas por volumes, mas também por cores, movimentos, odores, sons etc. Devido a estas características, a paisagem torna-se objeto da percepção humana, do universo subjetivo dos indivíduos onde:

[...] estão incluídos os sentimentos em relação às paisagens, ou seja, afetividades, vivências, experiências, valores, a cultura simbólica, as representações, identidades e territorialidades, que, segundo o tipo de experiência com a Natureza, ou percepção, reflete diferentes sentimentos e comportamentos com relação a ela. Para cada pessoa ou grupo a paisagem terá um significado, porque, as pessoas atribuem valores e significados diferentes às suas paisagens, traduzidos em sentimentos de enraizamento ou desapego aos lugares. (RISSO, 2008, p.72-73, grifo nosso)

Deste modo, a paisagem é diferentemente valorizada pelas pessoas que nela atuam (de acordo com o grau de ligação que venham ter com a mesma) e por isto nos permite adentrar no mundo das representações da natureza, entre a sensibilidade e a subjetividade. Novamente destacamos a importante contribuição de Georges Bertrand neste sentido: ou seja, de recolocar a paisagem no cerne da fronteira entre a problemática social e a naturalista, no âmbito do território. Segundo o autor:

A paisagem tornou-se a representação mais familiar e mais concreta do meio ambiente. A este título, ela constitui uma incomparável ferramenta de diálogo e de projeto para a organização/gestão [...], assim como um formidável caminho para a formação pedagógica. [...] A paisagem tornou-se muito importante para ser reduzida unicamente ao paisagismo. (BERTRAND, 2007, p.212, grifo nosso)

E esta importância está freqüentemente vinculada às possibilidades que a paisagem oferece tanto como representação sociocultural e objeto da percepção humana quanto ponto de partida para a análise das dinâmicas socioambientais de um dado território, suas transformações históricas e, também, ponto de partida para a reflexão sobre formas de intervenção na realidade (objetivando o desenvolvimento local, por exemplo). A paisagem é caracterizada, antes de tudo, pela transversalidade: ela é categoria de análise; objetividade; subjetividade; (i)materialidade e possibilidade...

As sociedades/as pessoas percebem seu espaço de vivência, adquirem, formam e transmitem conhecimentos sobre seus lugares e territórios por meio da linguagem, de 
sons, de sabores, odores e imagens (rurais ou urbanas; belas; degradadas; saudosas; repulsivas etc.). "A dimensão da paisagem é a dimensão da percepção". (SANTOS, 1997, p. 62). É esta última que define o grau da reação dos indivíduos às paisagens atribuição de valores, sentimentos, identidade. É ela que expressa quais as paisagens que realmente fazem parte da vida e do quotidiano de cada um dos indivíduos e suas particularidades.

Renó (2009) em sua Tese de Doutorado intitulada “O Sertão Mineiro: um território em busca de suas paisagens e de suas identidades" apresenta uma interessante discussão a respeito da relevância da paisagem enquanto categoria geográfica que nos permite adentrar no universo simbólico da sensibilidade e aprofundar nosso conhecimento sobre as diversas representações do território.

Ribeiro (2007) expõe o valor da paisagem como conceito científico, em detrimento de algumas críticas que negam este valor relevado à paisagem devido à carga de subjetividade e polissemia subjacentes à sua definição. $\mathrm{O}$ referido autor nos lembra que paisagens são "locais de interação entre materialidade e as representações simbólicas" (p.9) e, deste modo, nos permitem perceber o sentido do mundo no qual estamos.

Conforme Serpa (2007):

A paisagem resulta sempre de um processo de acumulação, mas é, ao mesmo tempo, contínua no espaço e no tempo, é una sem ser totalizante, é compósita, pois resulta sempre de uma mistura, um mosaico de tempos e objetos datados. A paisagem pressupõe também um conjunto de formas e funções em constante transformação, seus aspectos "visíveis", mas, por outro lado, as formas e as funções indicam a estrutura espacial, que é, em princípio, "invisível" e resulta sempre do casamento da paisagem com a sociedade. (p.15, grifo nosso)

Neste sentido, podemos considerar a paisagem nos termos da seguinte relação:

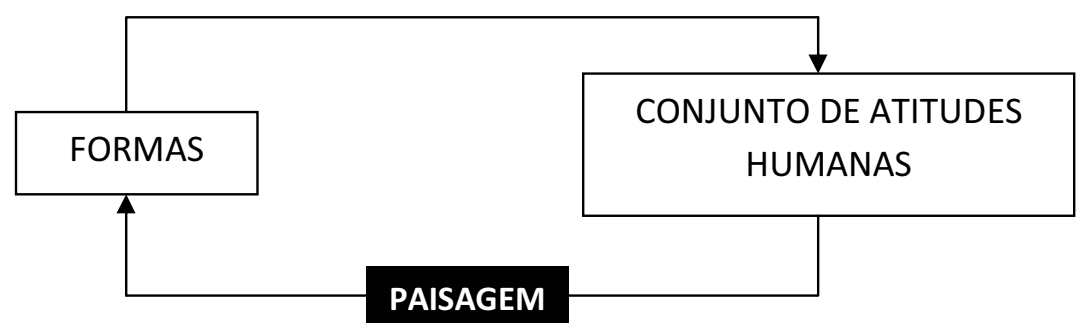


De modo que, a nosso ver, a paisagem sempre implicará não apenas nas formas produzidas a partir das ações da sociedade, mas na própria influência que estas formas exercem nas atitudes das pessoas quotidianamente. Esta relação não se manifesta de maneira cíclica certamente. Existem aspectos subjetivos em seu conteúdo. Sua evolução ocorre de modo espiralado. Acompanhando toda dialética inerente ao próprio indivíduo; ao indivíduo em suas relações com o outro e à sociedade com o seu território.

Anteriormente expusemos que a paisagem é algo como uma "explosão" entre aparências e essências, entre a objetividade e a subjetividade. Assim, consideramos de extremo interesse levar em conta uma abordagem que faça referência à percepção dos indivíduos: às pessoas que constroem e/ou vivenciam as suas paisagens. Assim:

Parfois il faut laisser la notion se dérober des concepts qui voudraient l'encadrer dans une définition trop rigoureuse. L'important est de bien se positionner et d'avoir clair à l'esprit les objectifs de son analyse. Après, s'il y a plusieurs concepts et définitions qui sont en accord avec l'intérêt de la recherche, pourquoi pas? Pourquoi en choisir seulement $u n$, ou encore essayer d'en produire un nouveau alors qu'on peut considérer que les choses essentielles ont été dites?43 (RENÓ, 2009, p.82)

É importante destacar que não pretendemos, aqui, construir uma nova possibilidade de análise da paisagem - até porque o tratamento de seus aspectos simbólicos vem sendo desenvolvido desde muito tempo por diversos autores -, mas sim adotar alguns elementos deste tipo de abordagem que enriquecem a análise sobre as dinâmicas socioambientais em nossa área de estudo.

Conforme salientamos, diferentes autores consideram a importância da dimensão subjetiva da paisagem (BERTRAND, SANTOS, RENÓ, SERPA, RIBEIRO etc.). As abordagens destes autores nos remeteram à relevância da análise da percepção das pessoas como forma de se obter informações sobre as dinâmicas socioambientais no território.

\footnotetext{
43 Às vezes é preciso deixar a noção se esquivar de conceitos que pretendem a enquadrar em uma definição muito rigorosa. 0 importante é bem se posicionar e ter claro ao espírito os objetivos de sua análise. Depois, se há vários conceitos e definições que estão de acordo com o interesse da pesquisa, por que não? Por que escolher somente um, ou ainda ensaiar a produção de um novo se podemos considerar as coisas essenciais que já foram ditas? (Tradução nossa)
} 
Com base nestas visões, montamos um esquema (15) que auxiliou na elaboração do guia de questões que utilizamos para realizar entrevistas semidirigidas junto aos moradores da alta bacia do ribeirão Santo Antônio, conforme demonstraremos em seguida:

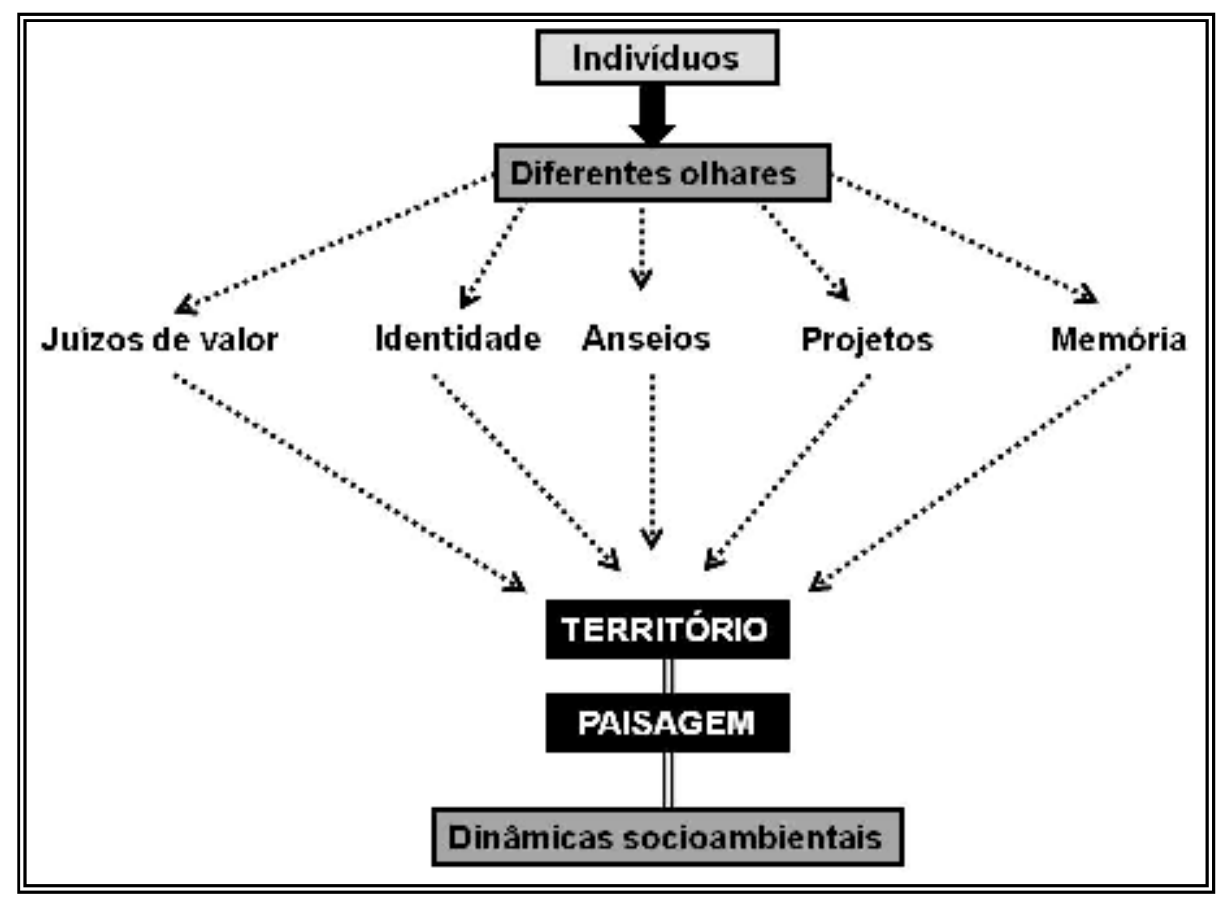

Esquema 15: Convergência de diferentes olhares sobre o território e a paisagem. Todas as formas de um indivíduo apreender seu espaço de vivência nos fornecem importantes elementos para aprofundarmos nosso conhecimento sobre as dinâmicas socioambientais em um dado território. (Org.: Reginaldo J. Souza)

Os indivíduos projetam sentimentos diversificados sobre o território e sua paisagem. Estes olhares se entrecruzam a partir de:

- juízos de valor: as pessoas expressam as características positivas ou negativas, boas ou ruins a respeito dos lugares em que vivem;

- identidade: sentimento de pertencimento (ou não) a um determinado lugar;

- anseios: as pessoas esperam ou buscam transformações; temem (ou querem) certos acontecimentos;

- projetos: dos individualistas aos de bem comum - entre a busca individual e quotidiana pela sobrevivência em um determinado lugar até a organização coletiva 
para facilitar os meios de sobrevivência neste mesmo lugar (por exemplo: uma associação de moradores, uma cooperativa agrícola etc.)

- memória: as lembranças de acontecimentos passados; de fatos que marcaram/moldaram um determinado modo de ver $o$ e agir no mundo.

Tendo em vista estas reflexões, partimos para as entrevistas na bacia do ribeirão Santo Antônio no município de Mirante do Paranapanema. Após nosso trabalho de coleta de dados e informações, que contribuíram para análise sobre as dinâmicas socioambientais no município, em visitas técnicas à Prefeitura Municipal, ITESP e Promotoria do Meio Ambiente, decidimos direcionar nosso foco para a população local por ser esta a que mais está diretamente ligada às paisagens da bacia hidrográfica em questão, possibilitando o enriquecimento da presente análise.

Conforme anteriormente apresentado, no âmbito da abordagem do meio ambiente por meio do sistema GTP, é preciso que se considere a dimensão da percepção dos indivíduos sobre seu espaço de vivência. Os dados e informações coletados nas instituições foram/são de fundamental importância ao nosso estudo, porém, não poderíamos desconsiderar a riqueza de informações fornecidas por aqueles que movem o quotidiano da referida bacia, ou seja, os seus moradores (com seus diferentes olhares e suas memórias).

Então, passaremos à exposição da análise das entrevistas.

\section{3) Análise das entrevistas}

A partir de critérios apresentados ${ }^{44}$, optamos pela seleção de nove moradores cujas residências se encontram (mormente) entre a alta e média bacia do ribeirão Santo Antônio $^{45}$. Antes de tudo, destacamos que o texto a seguir será estruturado em 13 itens correspondentes à ordem das questões estabelecidas em nosso guia de entrevista (conferir quadro 4, pg. 141). Nós elaboramos as questões de número 9 a 12 (diretamente referentes à apreensão da paisagem) com o intuito de fazermos um registro fotográfico

\footnotetext{
${ }^{44}$ No item "Sobre os procedimentos metodológicos" presente na introdução deste trabalho.

45 Vale frisar que dois entrevistados, dentre os nove que selecionamos, não moram mais neste local, porém, possuem lembranças/fontes significativas de informações para que incluíssemos na presente análise.
} 
de paisagens (ou elementos paisagísticos) indicadas (os) pelos próprios entrevistados; apresentaremos estas imagens mais adiante.

\section{Perfil dos entrevistados}

Os moradores entrevistados na bacia do ribeirão Santo Antônio estão em uma faixa etária entre os 48 e 78 anos de idade. Em sua maioria, sempre moraram em propriedades rurais. Nenhum deles vive sozinho em sua residência, compartilhando da moradia ou apenas com o (a) cônjuge ou com este (a) e a companhia dos filhos. Muitos deles são aposentados e complementam sua renda com a pequena produção de leite.

\section{Identidade e pertencimento: a ligação com o lugar}

Quando indagamos os moradores da bacia do ribeirão Santo Antônio sobre seu gosto ou não pelo lugar onde vivem, foi quase unânime a resposta "sim", sempre acompanhada de um complemento em seu discurso no intuito de reforçar esta afirmativa: “... porque aqui foi o lugar onde a gente se criou..." (José Donizete C., 48 anos); “... por causa do sossego, a resposta é na ponta da língua..." (Maria Alice A., 69 anos); “... porque sempre me dei bem neste lugar..." (Dionísio M., 60 anos); “... é um bairro muito sossegado"... (Maria Rosa M., 70 anos);

É importante destacar que um dos entrevistados, embora tenha demonstrado certa reticência ao responder “... não muito..." (Oswaldo M., 68 anos), isto se deu porque é na cidade que ele e sua esposa vivem atualmente. $\mathrm{O}$ entrevistado apontou alguns fatores negativos que o levou a deixar sua propriedade na bacia do ribeirão Santo Antônio e passar a viver na área urbana de Mirante do Paranapanema: o problema da distância entre a propriedade e os serviços de saúde do município; este é certamente um fator negativo tanto para o entrevistado quanto para sua esposa porque ambos apresentam problemas de saúde que exigem certos cuidados. 
Quadro 4: Questionário aplicado aos moradores da bacia do Ribeirão Santo Antônio - Mirante do Paranapanema.

\begin{tabular}{|c|c|}
\hline \multicolumn{2}{|c|}{ Guia de questões: percepção da paisagem } \\
\hline Questões & Intenções \\
\hline 1- Nome, idade, estado civil, com quem mora. & $\begin{array}{l}\text { Conhecer o perfil dos moradores ou proprietários da bacia } \\
\text { do Ribeirão Santo Antonio. }\end{array}$ \\
\hline 2- 0 Sr.(a) gosta de viver neste lugar? Por quê? & $\begin{array}{l}\text { Analisar a ligação com o lugar, o sentimento de identidade, } \\
\text { de pertencimento. }\end{array}$ \\
\hline 3-Sempre morou aqui? & \\
\hline $\begin{array}{l}\text { 3.1- Sim: já teve oportunidade para viver em outro lugar? } \\
\text { Quais os motivos que lhe fizeram ficar aqui? } \\
\text { 3.2- Não: onde é que também já morou? Durante quanto } \\
\text { tempo? Quais os motivos que lhe fizeram sair daqui? O que } \\
\text { fez com que o Sr. (a) voltasse para cá? Quando esteve fora, } \\
\text { do que sentia mais falta (coisas, lugares, pessoas...)? }\end{array}$ & $\begin{array}{l}\text { Objetiva-se perceber se desde a primeira vez que a pessoa } \\
\text { chegou à sua propriedade, nunca tenha mudado e o que fez } \\
\text { com que nunca mudasse, em caso de oportunidade para tal. } \\
\text { Verificar o que impulsionou a saída do lugar, se sentiu falta } \\
\text { de alguma coisa demonstrando uma ligação e o que } \\
\text { impulsionou o retorno. }\end{array}$ \\
\hline $\begin{array}{l}\text { 4- Como era este lugar no passado }(10,20,30 \text { anos atrás)? } 0 \\
\text { município mudou muito deste tempo até os dias de hoje? } \\
\text { Em sua opinião quais foram as principais mudanças? }\end{array}$ & $\begin{array}{l}\text { Pretende-se comparar como era a paisagem da bacia do } \\
\text { ribeirão Santo Antonio no passado e como é na atualidade, } \\
\text { se os moradores perceberam as mudanças, o que eles } \\
\text { acharam dessas mudanças, se melhorou ou piorou a } \\
\text { paisagem. }\end{array}$ \\
\hline $\begin{array}{l}\text { 5- Quando o senhor (a) pensa neste lugar em que vive, qual } \\
\text { é a primeira imagem que lhe vem na cabeça? }\end{array}$ & $\begin{array}{l}\text { A intenção é que os moradores digam qual a paisagem que } \\
\text { mais os marcou, a de maior importância na vida deles. }\end{array}$ \\
\hline $\begin{array}{l}\text { 6- Qual é a importância do córrego e/ou de suas nascentes } \\
\text { no seu dia-a-dia? }\end{array}$ & $\begin{array}{l}\text { Verificar se os moradores sentem a necessidade da } \\
\text { existência do rio, tanto em termos econômicos quanto em } \\
\text { termos de afetividade. }\end{array}$ \\
\hline $\begin{array}{l}\text { 7- Como o senhor (a) avalia a situação dos recursos naturais } \\
\text { neste local? (Está boa? Ruim? Por quê?). }\end{array}$ & $\begin{array}{l}\text { Avaliar como os moradores percebem os recursos naturais e } \\
\text { deles se apropriam; se conseguem apontar mudanças ao } \\
\text { longo do tempo. }\end{array}$ \\
\hline 8- De que forma o senhor (a) pensa o futuro deste lugar? & $\begin{array}{l}\text { Verificar se os moradores possuem alguma perspectiva para } \\
\text { o futuro da bacia do ribeirão Santo Antônio. Procurar que } \\
\text { eles expressem suas esperanças. }\end{array}$ \\
\hline $\begin{array}{l}\text { 9- Qual imagem (ens) o senhor (a) levaria deste lugar em } \\
\text { caso de uma mudança amanhã? Por que esta imagem? }\end{array}$ & $\begin{array}{l}\text { A intenção é extrair um sentimento que os moradores } \\
\text { possuem das paisagens que fazem parte do cotidiano de } \\
\text { cada um deles, uma paisagem que seja íntima. }\end{array}$ \\
\hline $\begin{array}{l}\text { 10- Quais fotografias o senhor (a) enviaria a um parente que } \\
\text { está distante para que ele conheça o lugar onde vive? }\end{array}$ & $\begin{array}{l}\text { Verificar quais paisagens os moradores consideram que são } \\
\text { importantes na estruturação da propriedade e que a } \\
\text { identificam. Uma paisagem identitária. }\end{array}$ \\
\hline $\begin{array}{l}\text { 11- Quais paisagens, ou quais elementos da paisagem lhe } \\
\text { choca mais. Qualquer coisa que você considere negativo e } \\
\text { que você gostaria que desaparecesse. }\end{array}$ & $\begin{array}{l}\text { Paisagem que seja desfigurada, que não tem valor para o } \\
\text { proprietário e que, portanto deveria desaparecer. }\end{array}$ \\
\hline $\begin{array}{l}\text { 12- Quais paisagens você pensa que deveriam ser } \\
\text { fotografadas porque daqui a algum tempo elas não existirão } \\
\text { mais? Em sua opinião, por quais motivos esta (s) paisagem } \\
\text { (ens) deixará (ão) de existir? }\end{array}$ & $\begin{array}{l}\text { Verificar se os moradores percebem mudanças drásticas na } \\
\text { paisagem e o que pode vir a desaparecer. }\end{array}$ \\
\hline $\begin{array}{l}\text { 13- A sua vida neste local está melhor agora do que no } \\
\text { passado? Por quê? }\end{array}$ & $\begin{array}{l}\text { A intenção é perceber se os moradores preferiam a vida do } \\
\text { passado ou a atual. A idéia é apreender como as } \\
\text { transformações socioeconômicas no município influenciam } \\
\text { a opinião do morador sobre suas atuais condições de vida. }\end{array}$ \\
\hline
\end{tabular}

Orgs.: Messias M. dos Passos; Thislainy Kanevieskir; Reginaldo J. Souza. 
O entrevistado gosta de sua propriedade (atualmente administrada por um funcionário) e da idéia de nela voltar a viver - há felicidade e empolgação quando se refere ao sítio. O que lhe causa certo desagrado é não poder realizar seu desejo devido aos seus problemas de saúde.

\section{A permanência no lugar}

Diante de nossa pergunta sobre o tempo de permanência ou períodos de ausência dos entrevistados, seja na bacia do ribeirão Santo Antônio ou no município, tomamos conhecimento de que quatro pessoas deixaram sua propriedade ou o trabalho naquelas terras e foram morar: no município de Santo Anastácio ("Já moramos em Santo Anastácio" - Maria Rosa M.) -, Dracena e Ribeirão dos Índios (Maria Alice A.); no município de Ponta Porã-MS (“Só passei um ano no exército, em Ponta Porã"- Quintino M., 72 anos) e em São Paulo ("Mas fiquei um mês, só"- José Donizete C.). Os outros entrevistados alegaram nunca terem deixado suas terras ou o município de Mirante do Paranapanema, seja por falta de oportunidade ou simplesmente pela própria vontade em permanecer. Dois deles não vivem mais na bacia do ribeirão Santo Antônio, de modo que um está no distrito de Costa Machado e o outro na área urbana do município.

É interessante destacar os motivos do retorno dos entrevistados que ficaram por algum tempo ausentes. Geralmente alegaram o apego e o costume à vida no local. Uma das entrevistadas evidenciou que nunca mais se deslocou para outros lugares após ter adquirido sua propriedade devido ao prazer que tem em realizar seus serviços no campo bem como ao sossego que conseguiu encontrar. (Maria Alice A.) Outro entrevistado nos respondeu que gostava muito da lavoura e era acostumado com o sítio, por isso resolveu deixar a capital do estado e voltar à vida rural, estando totalmente enraizado à sua terra, ao seu lugar de moradia - "Cidade pra mim é só pra passeio". (José Donizete C.) 
Transformações da paisagem na perspectiva dos entrevistados

Sobre as principais transformações paisagísticas apontadas pelos entrevistados, a maior parte dos aspectos dizia respeito à passagem da produção com base na lavoura (sobretudo tendo o algodão e o amendoim como principais produtos) para as pastagens nos dias atuais. Comumente, após estes apontamentos, fizeram menções ao esvaziamento populacional na área da bacia do ribeirão Santo Antônio: um dos entrevistados falou - nostálgico - sobre o fim da lavoura e imediatamente lamentou a partida de vizinhos, amigos e familiares: "Aqui antes era melhor porque era cheio de lavoura, entendeu? Você chegava no sítio aqui, era cheio de gente, era pai, era as irmandade tudo". (José Donizete C.);

É interessante destacar que alguns entrevistados também aludiram aos impactos ambientais ocorridos tanto na bacia quanto no município: o assoreamento do córrego, a retirada da vegetação ciliar e o desmatamento de um modo geral: “... tinha córrego que eu cansei de pescar de vara. Pegava cada traira! Hoje em dia você não pega mais. Não tem nada disso... tá tudo seco”. (Maria Alice A.); “... o povo tá derrubando os pé de pau perto do rio. O rio tá secando". (Maria Alice A.); “No passado era mato. Era mata pura, as pessoas chegavam lá e derrubavam pertinho do córrego"(Francisco L., 78 anos).

Outra resposta referente à questão sobre as principais mudanças que o entrevistado percebia, entre tempos pretéritos e o atual, foi muito interessante. Na visão de um deles, "o movimento da cidade era em função do povo do sítio, tinha um movimento, o povo comprava, era um povo alegre e hoje você vê a cidade, as pessoas com mão cruzada não tem para quem vender, acabou o estímulo, eu acredito que seja devido à agricultura" (Oswaldo M.). É importante salientar que este morador vive atualmente na área urbana do município, seu espaço de vivência, agora, é a cidade. Provavelmente por este motivo ele é capaz de fazer tal análise sobre a influência que o rural exercia sobre o urbano à época da produção agrícola mais intensa.

\section{Paisagem e memória: um acontecimento marcante na vida do entrevistado}

No intuito de melhor compreender a eventual ligação do indivíduo a alguma paisagem específica que estivesse vinculada a um acontecimento especial de sua vida, 
procuramos saber dos entrevistados qual seria ou quais seriam as imagens que lhe vêm em mente ao pensar no lugar em que vivem.

Regra geral, no discurso dos entrevistados houve referências à saudade de familiares e amigos/vizinhos que deixaram de viver ali. Na memória dos mais velhos, a saudade dos pais que faleceram e dos filhos que foram trabalhar em outras cidades. Mostraram muita saudade da alegria das festas, das reuniões de toda a família como também dos vizinhos, pois havia muitas pessoas morando na bacia, sendo que hoje muitos se sentem solitários.

Aludiram, também, ao progresso da lavoura no passado e que hoje em dia não existe mais. Em certos instantes foi possível perceber a ligação que os entrevistados faziam entre presença de familiares e amigos em sua propriedade com a prosperidade da lavoura: "A primeira imagem que eu lembro é da família tudo junto e daquele progresso da lavoura né”. (José Donizete C.); “Açúcar nóis fabricava, feijão nóis colhia, arroz também. Era muito gostoso porque tinha amizade. Hoje você sabe que não tem amizade". (Francisco L.)

Dentre os entrevistados, três deles nos responderam de modo um pouco diferente do comum, salientando a alegria pela compra da propriedade, a saudade dos tempos em que tinha mais saúde e capacidade para o trabalho no sítio e as dificuldades financeiras enfrentadas pela família: “Consegui comprar este sítio com aquele esforço, tocando aquela roça né, com um alqueirinho, um alqueire e pouco. Então eu penso nisso daí né”. (Dionísio M.); “A lembrança que eu tenho é uma saudade daqueles tempos que a gente tinha saúde, podia trabalhar...". (Oswaldo M.); "Lembra quando a gente era criança, a dificuldade que a gente passava né? Era muito filho, era muitos irmãos". (Carlos S., 57 anos)

\section{A importância do córrego no quotidiano dos moradores}

Tomamos como objetivo, neste momento das entrevistas, conduzir o discurso dos entrevistados para o valor simbólico e também econômico que o ribeirão Santo Antônio tem em suas vidas. 
As respostas foram bem diversificadas. Um dos aspectos mais destacados foi a importância do córrego para a criação de gado, o que não nos surpreendeu diante da predominância das pastagens no local. Além do mais, os moradores frisaram a importância das nascentes que tem em sua propriedade, sobretudo para a manutenção do ribeirão: “Tem muita importância as nascente. Se não fosse as nascente não existia o rio né". (Dionísio M.); "Eu tenho grande privilégio porque nascem três nascentes na minha propriedade. Inclusive tem até uma água mineral, mas não posso desenvolver ela porque fica muito caro. A microbacia começa na minha propriedade". (Oswaldo M.)

Alguns moradores nos falaram, com certa angústia, sobre o assoreamento do ribeirão: “Assoreou tudo. Tem gente que fala em recuperar o rio, mas não vai recuperar não. Tá muito tarde, não recupera não”. (Quintino M.); “A gente lavava roupa. Morava aqui, mais ia lavar de oito em oito dias e lavava lá no córrego. Agora você não vê nada mais. Se acabou tudo. Acabou tudo". (Maria Alice A.). Os moradores vêem a degradação do rio como algo sem solução, não possuem mais a esperança de que ele volte a ser o que era antes, isso devido ao fato de terem presenciado - e, conseqüentemente, percebido - a grande mudança que ocorreu do passado para os dias atuais: antes o rio era profundo e agora, não mais...

Outro aspecto destacado pelos entrevistados foi a importância do ribeirão, no passado, para a pesca (fosse em momentos de dificuldades financeiras, conforme a senhora Maria Alice A., ou para pescaria de lazer); os banhos no rio e uso da força da água para movimentar um moinho de fubá -que não existe mais- foram detalhes lembrados por dois entrevistados de origem húngara (senhores Carlos S. e Francisco L.).

\section{Avaliação dos recursos naturais}

A respeito da percepção dos entrevistados sobre o estado dos recursos naturais locais ao longo dos anos, a maior parte deles respondeu que a situação está ruim. A perda da qualidade do solo, a diminuição da quantidade de água no ribeirão Santo Antônio e a escassez de chuvas foram as principais queixas dos moradores. 
Neste sentido, consideramos muito interessante as colocações de uma entrevistada ao afirmar que, no ano de 1946, quando adquiriu sua propriedade na área da bacia, a terra já estava fraca para o plantio de algodão (Maria Alice A.). Fato este que lhe trouxe prejuízos financeiros diante do crescimento insuficiente da lavoura.

\section{Expectativas para o futuro}

De um modo geral, os entrevistados possuem uma visão pessimista a respeito do futuro da bacia do ribeirão Santo Antônio. Suas respostas expressaram isto. Certamente as respostas não foram semelhantes, porém, ao realizarmos a transcrição das gravações percebemos o pessimismo sobre o futuro como elemento comum no discurso dos entrevistados.

Um deles apontou a falta de oportunidades para os habitantes mais jovens como um dos fatores que levam ao esvaziamento populacional; tal fato aliado a falta de políticas públicas para a agricultura, na visão do morador (José Donizete C.), levam a dúvidas sobre a vida futura e o próprio destino da sua propriedade; considera que só será possível permanecer no local aqueles que forem aposentados por terem a própria aposentadoria como garantia financeira.

Diante do aumento do cultivo de cana na região do Pontal do Paranapanema, perguntamos sobre a possibilidade dos moradores arrendarem sua propriedade para este tipo de produção. Via de regra, eles se mostraram reticentes. Não acreditam que a produção canavieira possa melhorar as condições de vida do pequeno proprietário assim como outros cultivos não responderam a expectativas em outros momentos: "Porque aqui foi o algodão, foi o amendoim, foi a mamona, foi o milho, foi a soja. Tudo foi bomba" (Marcelino M.). Afirmam que o pequeno proprietário não irá arrendar sua propriedade para cultivar a cana.

\section{Paisagem íntima: o que o entrevistado levaria do lugar em caso de mudança}

Entendemos a paisagem íntima a partir de algum sentimento que o morador confere a coisas, locais ou pessoas que fizeram ou ainda fazem parte de seu quotidiano. 
Consideramos que a relação entre o morador com o seu espaço de vivência pode ser apreendida de maneira mais aprofundada a partir da tentativa em compreender seus sentimentos, os significados e os valores dedicados ao lugar e suas paisagens.

As respostas dos moradores ao serem questionados sobre que imagem ou imagens levariam do lugar onde vivem - em caso de uma mudança futura - nos remeteram, na maior parte das vezes, a algo que poderíamos chamar de "paisagens sentimentais". O sossego da vida rural; a saudade de parentes ou amigos; a nostalgia aos tempos do progresso da lavoura no passado bem como do trabalho na mesma; saudade - inclusive - da força física e alta capacidade para o trabalho que hoje em dia são impedidas pelos problemas de saúde típicos da idade em que se encontram: “... a saudade que a gente não pode estar ali trabalhando". (Oswaldo M.)

Também foi possível perceber, por meio do discurso dos entrevistados, o apego aos aspectos materiais da paisagem: a propriedade em si, a roça, o gado, as árvores, o rio (principalmente no passado). Porém, as expressões deste apego também se vincularam às emoções: lembrança de filhos que ali não vivem atualmente; amigos; festas; união familiar no passado, propiciada pelo dinamismo do trabalho na lavoura; dos esforços ao adquirir a propriedade. Às vezes esta carga de sentimentos fazia com que os moradores ressaltassem o fato de que não pretendem partir para outros lugares: “Eu não pretendo mudar" (Oswaldo M.); “Eu, só daqui pro cemitério” (Quintino M.).

\section{Paisagem identitária: como o entrevistado apresentaria sua propriedade}

Procuramos entender como o morador da bacia do ribeirão Santo Antônio se referiria às principais características de sua propriedade para alguém que ainda não a conhecesse. Mencionamos a idéia de um "parente distante" para sermos mais didáticos em nosso questionamento (Quais fotografias o senhor enviaria a um parente que está distante para que ele conheça o lugar onde vive?). A intenção era a de obter os elementos de maneira mais objetiva possível porque neste momento das entrevistas solicitamos aos entrevistados que apontassem paisagens a serem fotografadas naquele instante. 
Notamos que as manifestações de interesse se detiveram pela captura de fotografias das residências e de outros elementos presentes nas respectivas propriedades (árvores, pomar, estrada, represa).

O pedido pela fotografia da residência foi o mais comum. Isso, provavelmente, está ligado ao declínio da lavoura: o tempo de trabalho que antes lhe era dedicado, atualmente não é mais o mesmo. Assim, a casa se tornou o local de maior permanência da maioria dos entrevistados. É onde passam maior parte de seu tempo. Talvez seja por isso lhe destinam tanta afeição: na casa há representação/projeção de suas vidas.

\section{Aspectos negativos da/na paisagem}

A respeito dos aspectos paisagísticos que incomodam os entrevistados, suas respostas foram diversificadas. Dentre elas, optamos por destacar as queixas de dois moradores a respeito da possibilidade de transtornos com o aumento da produção canavieira nas proximidades de suas propriedades: "Quando começaram esse plantio ai de cana eles têm que passar dentro da minha propriedade. Já aborreceu um pouco. Minhas porteiras, já quebraram minhas porteiras. Quer dizer, você faz uma coisa pra depois quebrarem né, você não fica contente”(Dionísio M.); “Tá havendo uma coisa que vai vim um aborrecimento aqui, eu acho, que é o negócio da usina da cana aí. Não tá aborrecendo ainda, mas futuramente vai aborrecer. Vai ser queimação. Eu gostaria que tivesse lavoura ao invés da cana" (José Donizete C.).

Alguns entrevistados se mostraram reticentes e não apontaram nenhum aspecto negativo em suas propriedades ou circunvizinhanças. Outros falaram de coisas corriqueiras: sujeira gerada por poeira e folhas secas; animais invasores que matam criações (aves).

\section{Paisagens em mutação}

Para entendermos a visão dos moradores a respeito das paisagens em mutação na área da bacia, solicitamos que os entrevistados nos apontassem alguns elementos 
que pudessem ser fotograficamente registrados diante da possibilidade de deixarem de existir.

Um dos moradores não nos sugeriu nenhuma fotografia, pois, em sua opinião, o que não deveria desaparecer, havia desaparecido: "As matas não deveriam ter desaparecido" (Francisco L.).

Outro morador fez uma colocação interessante. Para ele os pastos deveriam ser fotografados perante a possibilidade de se tornarem áreas de cultivo de cana: "A paisagem é o capim né, os pastos. Pode ser que qualquer dia muda pra cana né" (Dionísio M.).

As respostas mais subjetivas se caracterizaram por alusões às "paisagens sentimentais": fotografias dos tempos em que um morador domava animais (Quintino M.); fotografias dos filhos que não moram mais na propriedade (Maria Alice A.); fotografias de objetos simbólicos (valorizados por remeterem a lembranças de alegrias passadas, dos pais, da infância)...

\section{Comparações entre o passado e o presente}

Para finalizar as entrevistas, pedimos aos moradores que avaliassem suas atuais condições de vida com relação ao passado e expusessem sua preferência por este ou aquele momento.

Regra geral, as preferências pelas condições de vida (no presente ou no passado) foram muito relativas quando consideramos o grupo dos entrevistados. Alguns afirmaram que nos dias de hoje possuem uma vida mais confortável. Outros afirmaram que nos dias de hoje a situação é mais difícil. Entre eles, também estiveram aqueles com opiniões flutuantes (hoje está melhor em termos...; hoje está bom, mas o passado era melhor...; aquele tempo era bom, mas hoje está melhor...).

Para os que preferem as condições atuais de vida, os motivos estão ligados ao maior conforto proporcionado por serviços de infra-estrutura (eletricidade, água encanada, comunicações) e pela diminuição do esforço físico para o trabalho na 
propriedade (devido à aposentadoria ou à produção de leite - atividade menos exigente se comparada à lavoura).

A opinião dos mais apegados à vida melhor no passado é formada a partir da lembrança do dinamismo da produção agrícola (algodão e amendoim) e, para alguns, da saúde física e maior capacidade para o trabalho mais pesado na lavoura.

\section{4) As representações paisagísticas na bacia do ribeirão Santo Antônio}

A dimensão a ser tratada, a partir da realização e análise das entrevistas com os moradores da referida bacia hidrográfica, foi aquela da percepção e representação do lugar, do espaço de vivência. Por isto, para analisar as percepções sobre o lugar e suas representações, optamos por incluir algumas perguntas que estivessem diretamente ligadas ao olhar do morador sobre a paisagem que o cerca (conforme apresentado no item anterior).

Desta forma, chegamos a um ponto onde a ligação entre fala e imagem seria de fundamental relevância para aprofundar o nosso conhecimento sobre as diferentes formas de reação das pessoas entrevistadas diante da (s) paisagem (ens) que irrompem tanto à frente quanto atrás de seus olhos, em suas memórias... E o melhor instrumento para abordagem do aspecto paisagístico desta representação, em nossa avaliação, foi a fotografia.

E por que a fotografia?

Porque por meio dela seria possível captar não apenas a paisagem ou seus elementos em si. A intenção principal era entender quais os motivos que levariam o morador/o entrevistado a apontar uma ou outra paisagem / um ou outro objeto a ser fotografada / fotografado.

A "Fotografia é Memória e com ela se confunde" (KOSSOY, 2000, p.132). Adotamos esta máxima e de algum modo a incorporamos aos nossos objetivos durante a realização das entrevistas, pois:

[...] a fotografia instaura [...] não uma consciência do estar aqui do objeto (o que qualquer cópia poderia fazer), mas a consciência do ter estado aqui. Trata-se, pois, de uma nova categoria de espaço-tempo: local-imediata e 
temporal-anterior; na fotografia há uma conjunção ilógica entre o aqui e o antigamente. (BARTHES, 1990, p.36, grifos do autor)

Em momentos anteriores à realização das entrevistas, decidimos utilizar o recurso da fotografia como forma de complementar certos aspectos do discurso dos entrevistados.

Durante as entrevistas, solicitamos às pessoas que nos indicassem algo que, em seu ponto de vista, deveria ser fotografado devido a motivos que perpassaram do estarrecimento - um "isto aconteceu assim" no sentido atribuído pelo semiólogo Roland Barthes (1990, p.36) - perante transformações muito rápidas (na vida do entrevistado, na sua propriedade, na bacia hidrográfica, na economia do município etc.) ao saudosismo que certos objetos ou situações eram/são capazes de gerar.

Ou seja, nossa intenção foi a de obter:

- imagens que identificassem os locais onde vivem os moradores;

- imagens que ativassem sua memória para acontecimentos significativos em sua vida;

- imagens de algo indesejado ou de coisas que estão prestes a desaparecer da paisagem.

Feitas estas rápidas considerações, passaremos à exposição das principais representações paisagísticas na visão dos moradores entrevistados na bacia do ribeirão Santo Antônio... 


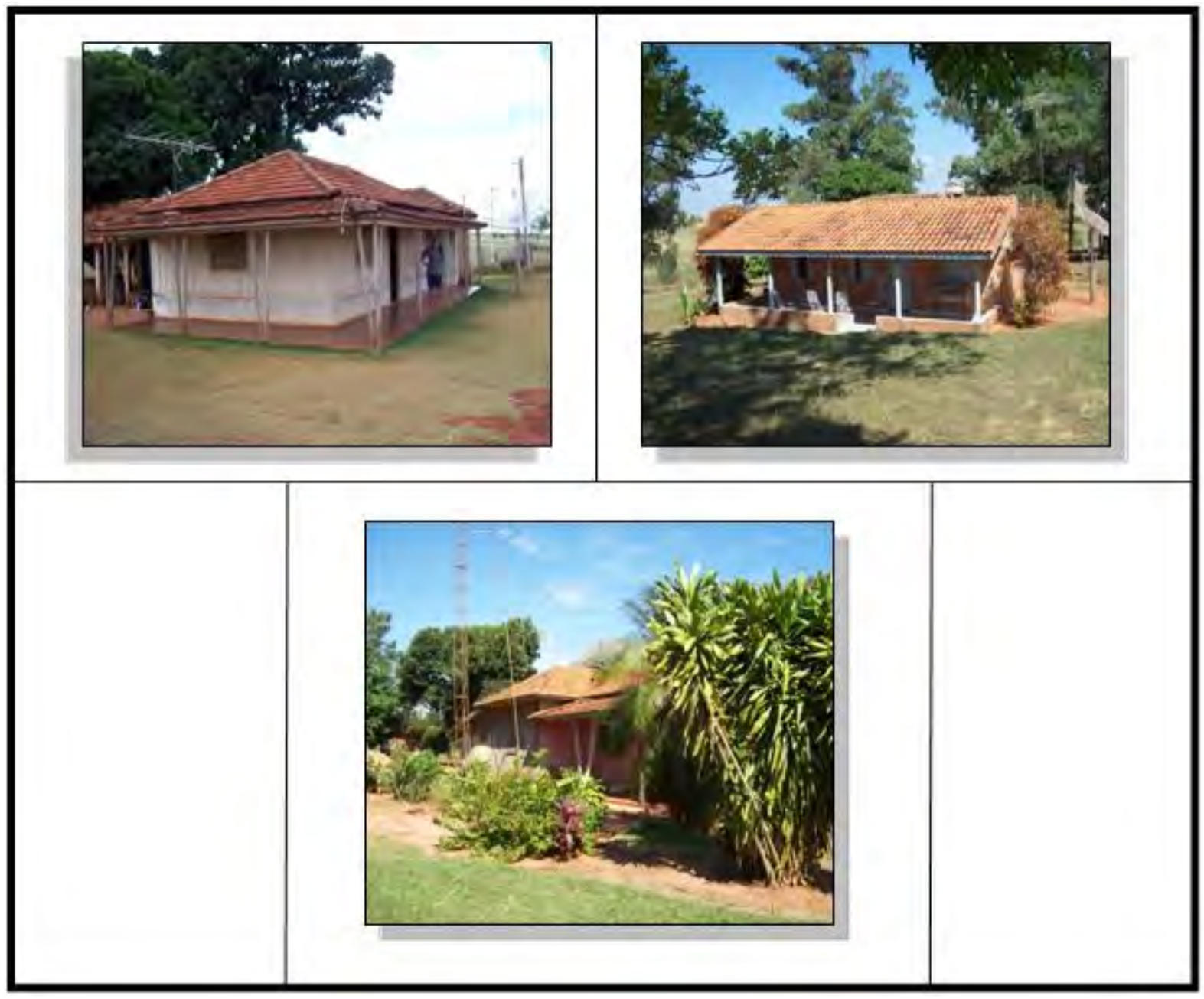

Quadro fotográfico V: Residências de moradores na bacia do Ribeirão Santo Antônio. Geralmente a casa teve posição privilegiada entre as preferências dos entrevistados para captura fotográfica de certos aspectos de sua propriedade. O trabalho na lavoura deixou de fazer parte do quotidiano dos moradores. Atualmente passam a maior parte de seu tempo neste local (mulheres e suas tarefas domésticas) ou imediações (homens e as tarefas dedicadas à pequena criação de gado). Foi possivel perceber esta atribuição de valor à residência em si a partir do discurso dos entrevistados. (Fonte das imagens: trabalho de campo, 2009) 


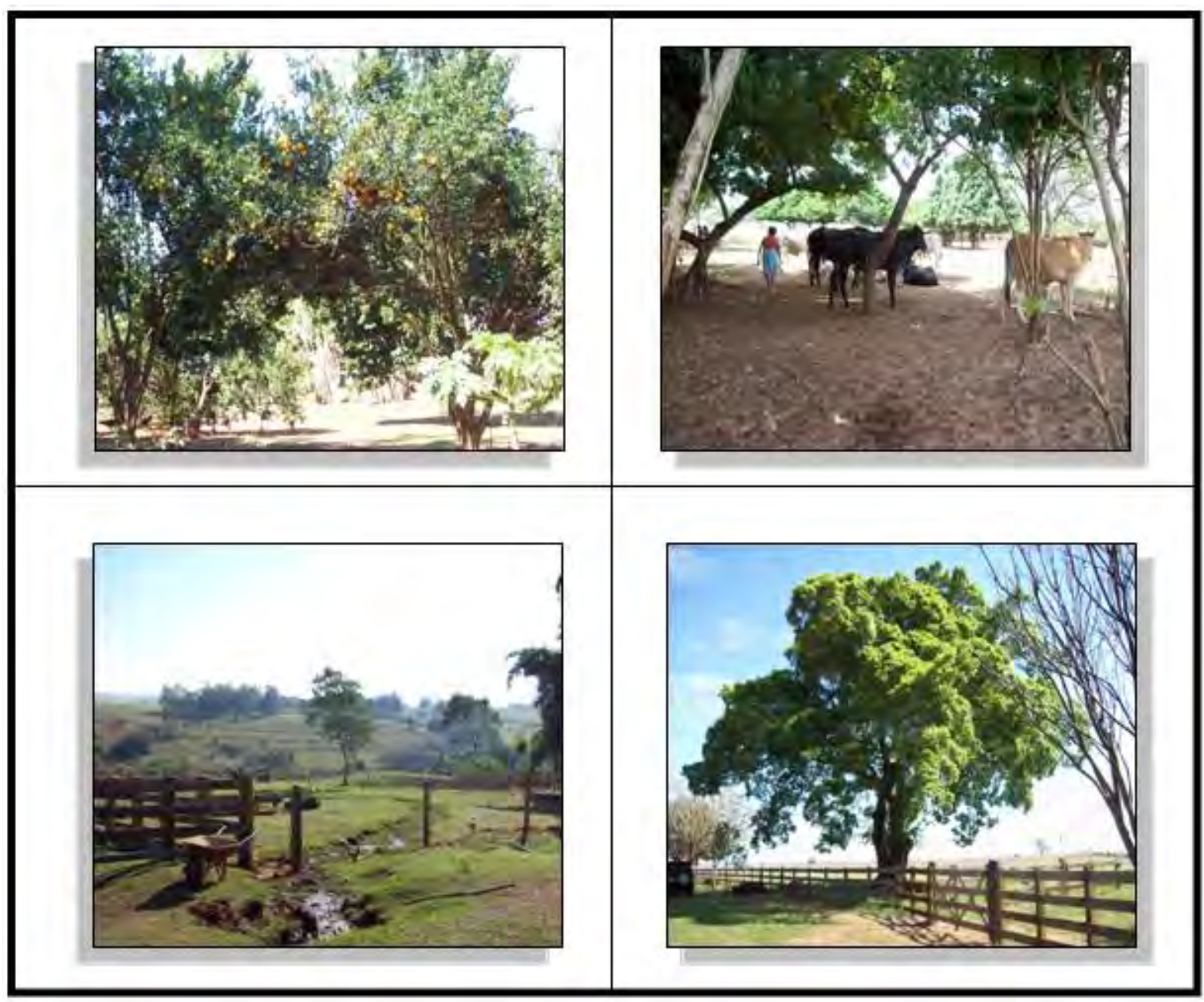

Quadro fotográfico VI: Aspectos das propriedades rurais localizadas na bacia do ribeirão Santo Antônio. Durante a realização das entrevistas aos moradores da área, questionamos-lhes quais seriam as melhores imagens (além de suas casas) para identificar seus sítios. As indicações para captura de fotografias de paisagens que identificassem o espaço de vivência se detiveram a elementos como: gado, pomares, pastagens, árvores, enfim, tudo o que fosse possível ser fotografado no âmbito da propriedade. (Fonte das imagens: trabalho de campo, 2009) 


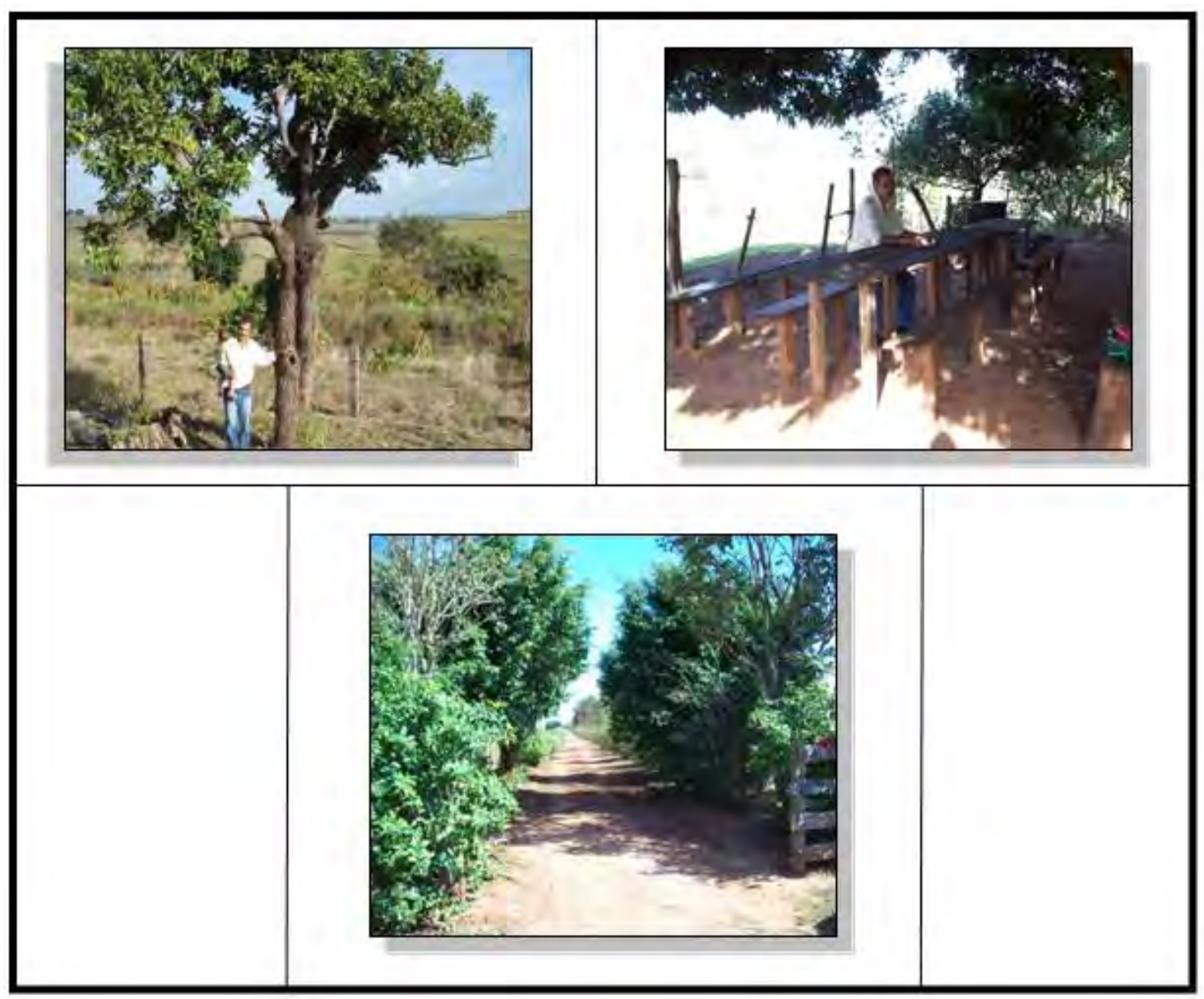

Quadro fotográfico VII: Imagens representativas de acontecimentos importantes na vida dos entrevistados. Ao questionarmos-lhes sobre acontecimentos marcantes em suas vidas, a maioria deles fez referência à presença de amigos e familiares que hoje em dia não estão mais presentes em seu quotidiano e sobre as sensações que o contato com estas pessoas proporcionava (felicidade, satisfação...). Geralmente fatos sobre os quais não havia um objeto a ser fotografado. Entre os entrevistados, houve aqueles que nos falaram destas mesmas sensações, mas também nos apontaram objetos que estavam ligados aos acontecimentos importantes em sua vida: uma árvore onde se brincava quando criança, a beleza da entrada da propriedade que remete à lembrança e à dedicação destinadas à mesma ou uma grande mesa de madeira em torno da qual se concentrava familiares e amigos em dias de comemorações de boas colheitas na lavoura. (Fonte das imagens: trabalho de campo, 2009) 


\section{\# Mutações}

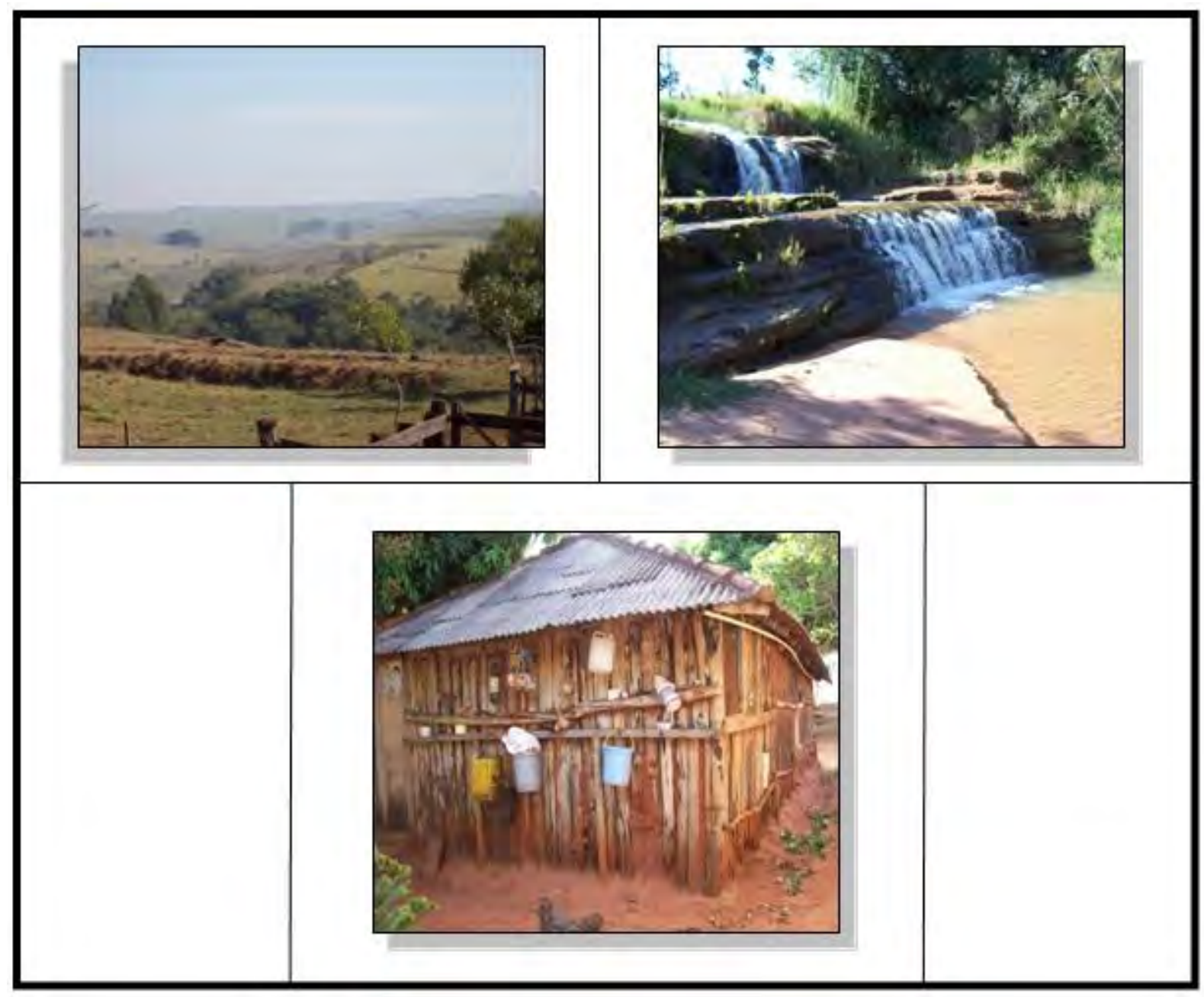

Quadro fotográfico VIII: Representações de paisagens que deixarão de existir na opinião dos moradores da bacia do ribeirão Santo Antônio. Embora a maioria dos entrevistados considere que nenhuma paisagem deixará de existir, alguns deles nos expressaram visões diferentes. Consideram que determinadas coisas, com o passar do tempo, não mais existirão. Os apontamentos se voltaram para as pastagens: um dos entrevistados acredita que futuramente estas serão, em sua maioria, substituídas pelo plantio de cana-de-açúcar. O "rio" e sua importância tanto em termos econômicos (água para o gado, por exemplo) quanto em termos simbólicos (lazer) foi citado enquanto um elemento paisagístico que provavelmente desaparecerá. Por fim, o antigo paiol presente na propriedade de um dos entrevistados; o proprietário pretende destrui-lo para algumas reformas em seu sítio. (Fonte das imagens: trabalho de campo, 2009) 


\section{5) Algumas considerações}

Para finalizar a reflexão a respeito da realização das entrevistas, novamente destacamos que nossos objetivos se detiveram em melhor compreender a maneira pela qual a população local apreende seu espaço de vivência e reage às atuais configurações da paisagem ao rememorar o passado, determinados acontecimentos marcantes e, sobretudo, as transformações socioambientais ocorridas no município de Mirante do Paranapanema.

É importante salientar que não priorizamos, em nenhum momento, a análise quantitativa das informações que tomamos conhecimento durante a realização das entrevistas. Estabelecemos um guia de questões, porém, sem a intenção de obter respostas objetivas das pessoas entrevistadas. E assim o foi. Baseamos as entrevistas naquele guia previamente planejado para que seguíssemos uma ordem de perguntas mais ou menos semelhantes com todos os entrevistados. Variações na condução destas perguntas ocorreram de um modo geral. Desta forma, jamais seria possível tentar elaborar uma análise de cunho quantitativo/estatístico a respeito da subjetividade dos indivíduos entrevistados.

Assim, acreditamos que não nos seja permitido concluir, enquadrar e encerrar a nossa análise. Pudemos, isto sim, levantar algumas considerações sobre a relevância do discurso das pessoas entrevistadas para aprofundarmos nosso conhecimento a respeito das dinâmicas socioambientais neste território.

Inclinamo-nos aos fundamentos teóricos de alguns autores no que diz respeito à abordagem geográfica de categorias como território, paisagem e ambiente (conforme apresentado no início deste capítulo). A proposta teórica de Bertrand (2007) nos motivou a buscar na percepção dos moradores da bacia hidrográfica, alguns elementos importantes para uma compreensão - que procura fugir de setorizações - não apenas da paisagem em si. Mas da paisagem inserida em um território. Uma paisagem viva e que se transformou/transforma no decorrer do tempo. Uma paisagem entre natureza e sociedade, (in)tensamente (re)desenhada ao ritmo da história movida pelos homens. Uma paisagem objetiva/visual, mas também subjetiva/emocional. 
Por meio das entrevistas pudemos claramente captar estas duas dimensões presentes nas falas dos moradores entrevistados. Aludiram aos aspectos físicos da paisagem. Lamentaram a atual ausência da lavoura nas propriedades rurais - tanto nas suas quanto em propriedades vizinhas. Visualizam a degradação do ribeirão Santo Antônio. Alguns afirmam, definitivamente, que a situação negativa em que o ribeirão se encontra é irreversível. Os entrevistados nos falaram de coisas e situações possíveis de serem captadas tanto pelos seus quanto por nossos olhares no exato momento em que conversávamos com eles.

Também nos falaram de coisas que não poderíamos fotografar. Suas memórias. A saudade de acontecimentos que ainda não se perderam no tempo porque fazem parte do conteúdo mais profundo de suas lembranças. Alguns sentem falta dos pais que pesadamente trabalharam para conquistar a terra e manter a propriedade. Outros, de irmãos e amigos que foram embora porque a vida no local se tornou mais difícil. Festas. Reuniões em família. Saúde física e maior capacidade para o trabalho... Paisagens? Sim. Talvez em um sentido transcendental, onde nossa postura acadêmica encontra limites para extrair e esmiuçar certas informações.

[...] nous trouvons quelques fois dans les discours sur le paysage des références sur des éléments et/ou situations qui n'existent plus physiquement, mais qui sont le paysage ou qui le composent ${ }^{46}$. (RENÓ, 2009, p.78, grifo nosso)

Diante disto, o que podemos, então, fazer?

Antes de tudo, reforçar a idéia da paisagem como categoria híbrida - assim como outras no contexto da ciência geográfica. Justamente por assim ser, ela assume grande relevância para a compreensão de certos fenômenos socioambientais. Espaço, território, paisagem, lugar, ambiente etc. são produtos/processos que resultam/irrompem nos limiares entre natureza e cultura. A escala do quotidiano é aquela na qual este contato é sentido de maneira mais imediata. As pessoas que dão vida ao quotidiano de seus lugares têm a (s) sua (s) visão (ões) de mundo e, dependendo do grau de enraizamento ao espaço de vivência, este mundo não ultrapassa a linha do horizonte. Mesmo em se

46 [...] algumas vezes nós encontramos, nos discursos sobre paisagem, referências sobre elementos e/ou situações que não existem mais fisicamente, mas que são a paisagem ou a compõe. (Tradução nossa) 
tratando de um horizonte composto por pastagens pobres assentadas em arenitos muito friáveis, facilmente erodidos e "recortados" por um córrego em nítido processo de assoreamento.

O apego do indivíduo ao lugar facilmente pode surpreender aquele que tenta o analisar não estando totalmente inserido naquela situação. O pesquisador se questiona: o que motiva alguém a gostar de viver neste ou naquele local? Será que este ou outro indivíduo (um morador entrevistado, por exemplo) não poderia adotar uma estratégia para não impactar - de modo negativo - a vertente, a mata ciliar, o curso d'água? Será que esta ou aquela pessoa se sente de alguma forma responsável pela degradação da qual ela própria levanta queixas? Não nos é permitido encerrar uma opinião pronta, um juízo de valor...

Devemos procurar, por meio de nossos estudos, intervir de alguma forma na realidade. Podemos oferecer fontes de informações por meio de nossas pesquisas. Podemos diagnosticar e prognosticar cenários. Pensar em estratégias que vão ao encontro de propostas de desenvolvimento local, minimizando certos desequilíbrios em benefício tanto das sociedades quanto de seu meio ambiente, seja na bacia do ribeirão Santo Antônio, no município de Mirante do Paranapanema, na Raia Divisória SP-PRMS... 
Considerações Finais

159 


\section{soce}

"As entradas geossistêmica, territoriale paisagística para a leitura dos fenômenos geográficos, nos permitirá finalizar um estudo com a certeza de que a multiplicidade de acontecimentos, fenômenos, temporalidades e espacialidades inerentes a todas as coisas que existem nos fará, cada vez mais, abandonar métodos unilaterais, conceituações estanques e procedimentos rígidos caso queiramos realmente dar conta de compreender ao menos um pouco da realidade a nossa volta.".

(Reginaldo José de Souza)

8003 
Atualmente, o discurso sobre o meio ambiente é multicêntrico, do senso comum à mídia; do ensino básico ao acadêmico; entre a filosofia e a ciência; entre as ciências naturais e humanas. À Geografia cabe o enfoque sobre a problemática ambiental dentro de um quadro teórico e metodológico específico, ou seja, aquele em que são abarcadas determinadas categorias de análise e conceitos que caracterizam esta ciência.

Neste sentido, tomamos o sistema GTP como referencial para o desenvolvimento da pesquisa. Este é, certamente, um sistema teórico-metodológico que nos permite adentrar na complexa temática do meio ambiente com vistas a captar a integração dos fenômenos híbridos: entre natureza e cultura.

Apresentamos o sistema GTP como um filtro de linguagem ou chave conceitual em ordem crescente para a entrada na questão ambiental. Com esta forma de abordagem, pretendemos demonstrar a gama de possibilidades, variações e direções que os estudos sobre a temática podem tomar.

O enfoque para a realidade socioambiental de um dado território, por meio do sistema GTP, nos leva a compreender de modo mais aprofundado um pouco da complexidade subjacente ao jogo de relações entre sociedade e natureza que determinam a produção e reprodução deste mesmo território.

Conforme dito por Georges Bertrand (em disciplina ministrada no PPGGFCT/UNESP, ano de 2007), seu sistema teórico-metodológico ainda apresenta algumas lacunas ou "caixas pretas" que precisam ser repensadas e superadas. E a nós, mesmo cientes de algumas destas dificuldades, nos coube visualizar e aplicar o GTP de acordo com as nossas possibilidades de análise e, também, de acordo com a nossa visão sobre este sistema, ou seja: as entradas geossistêmica, territorial e paisagística para a leitura dos fenômenos geográficos, nos permitirá finalizar um estudo com a certeza de que a multiplicidade de acontecimentos, fenômenos, temporalidades e espacialidades inerentes a todas as coisas que existem nos fará, cada vez mais, abandonar métodos unilaterais, conceituações estanques e procedimentos rígidos caso queiramos realmente dar conta de compreender ao menos um pouco da realidade a nossa volta.

Falando especificamente do nosso estudo sobre as dinâmicas socioambientais em Mirante do Paranapanema, salientamos que, em nossas análises, estivemos atentos 
desde a dimensão naturalista (não apenas dela em si, mas inserida em um contexto territorial) até aquela das representações (objetivas e subjetivas) da paisagem.

Houve uma série de desdobramentos negativos das ações antrópicas no município estudado desde momentos anteriores à sua emancipação políticoadministrativa até os dias atuais. Estes desdobramentos se materializaram na paisagem, uma representação imediata e/ou mediata da teia de relações que produzem e dinamizam o território.

Há uma processualidade inerente à paisagem que é dada por uma combinação entre diferentes tempos, atores e projetos (ou falta de projetos - algo próximo da "espontaneidade"). Estes fatores são perceptíveis em Mirante do Paranapanema quando caminhamos às margens dos ribeirões e nos surpreendemos com o nível de degradação e assoreamento dos mesmos.

Degradação esta que não começou por acaso. Ao contrário. Esteve e ainda está relacionada à cultura do imediatismo pouco atenta aos reflexos negativos que determinadas práticas podem disseminar futuramente.

O tempo da natureza é alterado pelo tempo da sociedade. A dinâmica do antrópico não se concilia com a dinâmica do natural e isto, por si, caracteriza o impacto. Tal incongruência foi perfeitamente verificável no município analisado e a pesquisa teve este fato ou fatalidade como foco.

Quais foram e quais são os atores (des)construtores da paisagem de Mirante do Paranapanema?

i) Foram os pioneiros colonizadores e plantadores que desde momentos anteriores à emancipação político-admnistrativa chegaram à área do atual município e geraram as alterações iniciais (desmatamentos e uso agrícola) do atual estado de degradação da paisagem: representativo da degradação ambiental que se reflete de modo negativo sobre a sociedade local.

ii) Foram os produtores de algodão que, incentivados pela chegada das empresas beneficiadoras (Anderson Clayton, Sanbra, MacFaden) na década de 1950, permaneceram nesta mesma produção por quase vinte anos, geralmente sem a adoção 
de técnicas adequadas de manejo do solo, levando ao seu empobrecimento e potencialização da velocidade dos processos erosivos que, em conjunto com as ações de desmatamento, contribuíram sobremaneira aos impactos ambientais.

iii) Foram e são os proprietários rurais que implantaram a pecuária extensiva (de corte e, sobretudo a leiteira) nas áreas que haviam sido relativamente prósperas durante o período das lavouras de algodão. Uma atividade que também ocorreu/ocorre em moldes poucos sustentáveis no que diz respeito à preservação do meio ambiente com vistas à própria manutenção da rentabilidade da produção: as pastagens são muito pobres, apresentam vários pontos críticos de erosões e, muitas vezes, não respeitam as áreas de preservação permanente ao longo dos córregos.

iv) No cenário atual, também são os produtores de cana-de-açúcar que vêm ganhando cada vez mais destaque devido aos incentivos à produção do etanol para atender às demandas do mercado nacional e para exportação. Embora o discurso dos grupos interessados apresente argumentos referentes a práticas pouco predatórias tanto nas usinas quanto nos canaviais, vimos que na realidade este discurso não é totalmente verdadeiro: conforme o exemplo de desrespeito às APPs e Reserva Florestal Legal com vistas à rápida implantação do cultivo de cana na área de uma fazenda entre os municípios de Mirante do Paranapanema e Presidente Bernardes (exemplo mencionado no capítulo IV).

v) São os pequenos proprietários rurais e os assentados, geralmente menos capitalizados, que baseiam sua produção na pecuária leiteira e isso torna seus ganhos dependentes de vários fatores: das variações climáticas (a estação seca compromete as pastagens e, conseqüentemente, a produção do leite) aos preços determinados pelos laticínios.

Em linhas gerais são estes os atores que construíram e constroem o cenário paisagístico do município. Cenário pleno em disjunções e dissimetrias. Cenário de um território construído por meios não muito adequados do ponto de vista da preservação ambiental, dos ganhos para a sociedade local, enfim, do verdadeiro desenvolvimento local sustentável. 
Com a realização deste trabalho, procuramos oferecer este panorama sobre a geografia do município. E também expor a nossa idéia sobre como devem ser realizadas as leituras e análises do meio ambiente no âmbito da ciência geográfica. Inclusive considerando meio ambiente como termo único e importante, ao contrário do que às vezes ouvimos em discursos ambientalistas mais radicais.

A composição meio + ambiente, jamais resultaria no significado de ambiente fracionado. Metade. Ambiente não analisado em sua integração e integralidade. Isto é um projeto impossível!

Na introdução deste trabalho, dissemos que o meio do termo meio ambiente deve ser lido como possibilidade-condição-intervenção. Como a forma de relação entre a sociedade e tudo aquilo que ela toma para si como recurso que julga necessário à sua (re)produção. Em termos esquemáticos, esta relação pode ser representada (de modo geral) da seguinte forma:

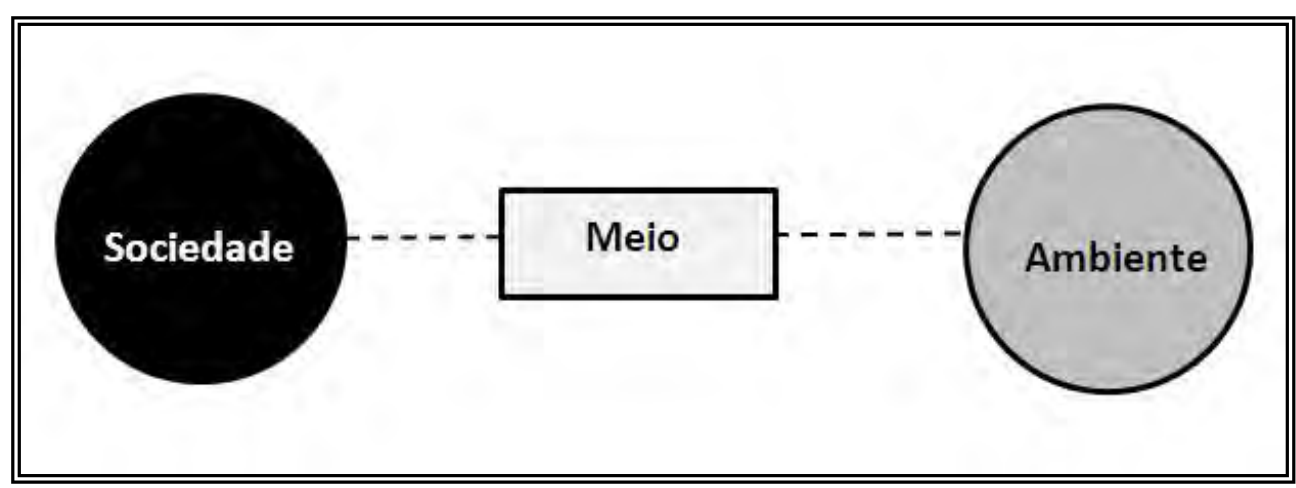

Esquema 16: Relação sociedade-meio-ambiente. (Esquema simples) Org. Reginaldo José de Souza.

E ao considerarmos especificamente o município de Mirante do Paranapanema, esta relação se abre conforme o próximo esquema: 


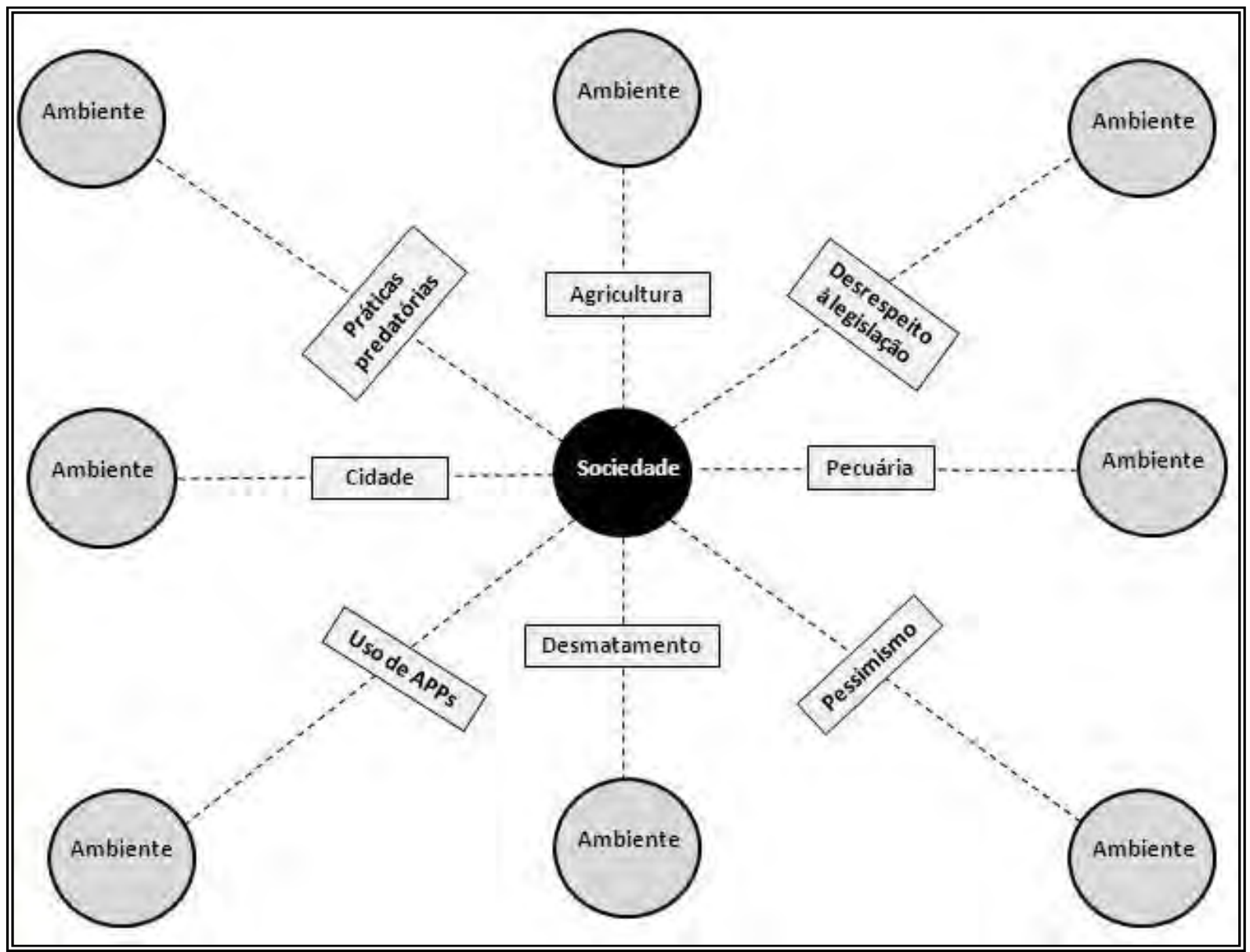

Esquema 17: Relação sociedade-meio-ambiente em Mirante do Paranapanema. Do esquema simples, partimos para este mais complexo justamente no intuito de demonstrar a pertinência em não considerarmos o termo "meio ambiente" como uma possibilidade de leitura fracionada daquilo que seria o "ambiente inteiro". Org.: Reginaldo José de Souza.

Neste sentido, mais do que nunca, o meio não pode ser ignorado ou simplesmente encarado como sinônimo de metade porque ele é o que representa as diferentes formas pelas quais a sociedade realizará a transfiguração da natureza ${ }^{47}$ de acordo com os seus objetivos e os respectivos contextos políticos, econômicos e culturais.

As transfigurações da natureza em Mirante do Paranapanema aconteceram e acontecem por meios diversificados: dos desmatamentos para a agricultura; desta para a pecuária; expansão das áreas de cultivo de cana; casos de desrespeito à legislação

47 "Transfiguração da natureza": expressão utilizada por SUERTEGARAY (2002, p.115-116) no sentido de enfatizar a artificialização da natureza pela sociedade, mas sem negar a própria essência da natureza mesmo que artificializada. 
ambiental vigente; enfim, maneiras variadas de alteração/produção do ambiente que parecem perpetuar um conjunto de práticas predatórias no município.

E ao falarmos de uma aparente perpetuação das práticas predatórias, não pretendemos expor deliberadamente o nosso pessimismo com relação ao quadro socioambiental que ali existe. Na realidade estas impressões advêm do contato que estabelecemos com os moradores. Sobretudo os moradores da bacia do ribeirão Santo Antônio que não acreditam na reversão do franco processo de assoreamento pelo qual o córrego passa.

Há possibilidade de prognosticar futuros cenários paisagísticos em Mirante do Paranapanema? Pensemos em alguns pontos:

$\left.1^{\circ}\right)$ O município se encontra no seio de um território fronteiriço - a Raia SP-PRMS. Cada uma das parcelas que compõem a Raia apresenta suas particularidades e suas semelhanças ao mesmo tempo. A presença de solos bastante friáveis e relativamente pouco propícios à agricultura é um dos fatores de semelhanças entre o Sudoeste Paulista, Noroeste Paranaense e Sudeste Sul Mato-Grossense. O Noroeste Paranaense conta com um programa resultante de parcerias entre Iapar, UEM, Prefeituras Municipais e uma empresa multinacional - Programa Arenito Nova Fronteira - que atualmente contempla a utilização agrícola e manejos mais adequados em áreas de solos areníticos. Atitudes como esta poderiam influenciar os municípios do Pontal do Paranapanema e promover algumas mudanças socioeconômicas e ambientais positivas, caso também fossem implantadas nesta região? Talvez sim, porém, elas ainda não atravessaram para a margem paulista do rio Paranapanema.

$2^{\circ}$ ) Existem ações dos programas Microbacias Hidrográficas e Melhor Caminho (governo estadual) em Mirante do Paranapanema, porém, estes programas não contemplam toda a área do município e as ações implantadas nas propriedades e lotes rurais muitas vezes não ocorrem de modo integrado: um proprietário associado implanta curvas de nível em suas terras, mas o seu vizinho não. Ou então, não dispõe de recursos para o cultivo e continua a utilizar a área como pastagem. Estes exemplos de ausência de práticas integradas contribuem para aumentar a ocorrência dos processos erosivos / assoreamentos / desperenização dos ribeirões. 
$\left.3^{\circ}\right)$ A presença das usinas pertencentes à Organização Odebrecht no Pontal do Paranapanema leva à expansão dos canaviais por toda a região e, conseqüentemente, no município analisado. Exemplificamos (capítulo IV) como este fato ainda faz perdurar o "espírito imediatista" de alguns proprietários no que diz respeito à eliminação da maior parte da vegetação (APPs e Reserva Florestal Legal) das fazendas em benefício do preparo das áreas para o plantio da cana.

Diante dos pontos supracitados, tendemos a pensar na permanência do atual modelo de reprodução do território (baseado em práticas muito inadequadas) no futuro mais imediato. A não ser que mudanças bruscas, com vistas à reversão do atual estado de degradação existente em Mirante do Paranapanema, passassem a acontecer a partir de agora ou...

Ou ao menos, tivessem sido iniciadas em anos anteriores.

Ao que nos parece, isso não vem acontecendo. 


\section{BIBLIOGRAFIA}

AB'SÁBER, Aziz. Os Domínios de Natureza no Brasil: Potencialidades Paisagísticas. São Paulo, Ateliê Editorial, 2003.

BARTHES, Roland. O óbvio e o obtuso. Rio de Janeiro: Nova Fronteira, 1990.

BERTRAND, Claude. BERTRAND, Georges. Une Géographie Traversière. L'environnement à Travers Territoires et Temporalités. Paris : Éditions Arguments, 2002.

Uma geografia transversal e de travessias: o meio ambiente através dos territórios e das temporalidades. Org.: Messias Modesto dos Passos. Maringá: Ed. Massoni, 2007.

BERTRAND, G. Paysage et géographie physique globales: esquisse methodologique. Révue de Géographie des Pyrenées et Sud-Ouest. Toulouse, v.39, p.249-72, 1968.

BRAUDEL, Fernand. História e Ciências Sociais. São Paulo: Perspectiva, 1978.

CAPRA, Fritjof. O Ponto de Mutação: a ciência, a sociedade e a cultura emergente. $22^{\mathrm{a}}$ ed. São Paulo: Cultrix, 2001.

CASSETI, Valter. Ambiente e Apropriação do Relevo. São Paulo: Contexto, 1991.

CAVACO, Carminda. Fronteira Portugal-Espanha e individualidade territorial. In: Finisterra, XXXII, 63, 1997. p.159-166. Disponível em: <http://www.ceg.ul.pt/finisterra/numeros/1997-63/63_17.pdf>. Acesso: março, 2009.

COMISSÃO EUROPÉIA. A abordagem Leader - um guia básico. Luxemburgo: Serviço das Publicações Oficiais das Comunidades Européias, 2006. Disponível em: <ec.europa.eu/agriculture/publi/fact/leader/2006_pt.pdf>. Acesso: março, 2009.

DEMATTEIS, Giuseppe. O Território: Uma Oportunidade para Repensar a Geografia. In: SAQUET, Marcos A. Abordagens e Concepções de Território. São Paulo: Expressão Popular, 2007. 
DIAS, Jailton. A Construção da Paisagem na Raia Divisória São Paulo - Paraná - Mato Grosso do Sul: Um Estudo por Teledetecçao. Presidente Prudente: UNESP/FCT, 2003. Tese (Doutorado) - Faculdade de Ciências e Tecnologia da Universidade Estadual Paulista, 2003.

DIAS, Janise. SANTOS, Leonardo. A paisagem e o geossistema como possibilidade de leitura da expressão do espaço sócio-ambiental rural. In: Confins, n.1, jun.. 2007, disponível em: http://confins.revues.org/document10.html. Acesso: 11/09/2007.

FLORENZANO, Teresa Gallotti. Imagens de satélite para estudos ambientais. São Paulo: Oficina de Textos, 2002.

FONSECA, Fernanda P. da. CZUY, Daniele C. Formação Arenito Caiuá: uso, ocupação do solo e problemas ambientais na região Noroeste do Paraná. In: Anais do Simpósio Nacional de Geografia Agrária, 3. Simpósio Internacional de Geografia Agrária, 2. Jornada Ariovaldo Umbelino de Oliveira. Presidente Prudente: UNESP, novembro de 2005.

FUNDAÇÃO PREFEITO FARIA LIMA - CEPAM. O município no século XXI: cenários e perspectivas. São Paulo, 1999.

GABINETE DE INICIATIVAS TRANSFRONTEIRIÇAS ALENTEJO, ALGARVE, ANDALUZIA. Direção geral de desenvolvimento regional, Portugal. Direção geral de fundos comunitários, Espanha. Programa operacional de cooperação transfronteiriça Portugal-Espanha, 2007-2013. Documento final preliminar para aprovação pela Comissão Européia. Maio de 2007. Disponível em: < www.gitaaa.com/GIT/noticias/noticias_51-pt.pdf>. Acesso: março, 2009.

GINÉ, David S. Paisaje y políticas públicas. In: Investigaciones Geográficas. Instituto Universitario de Geografía. Universidad de Alicante, nº42, 2007.

GUERRA, Antonio J. Teixeira. CUNHA, Sandra Baptista da (orgs.). Geomorfologia: uma atualização de bases e conceitos. Rio de Janeiro: Bertrand Brasil, 2001.

GONÇALVES, Carlos Walter P. Os (Des)caminhos do Meio Ambiente. 6 a edição. São Paulo: Contexto, 1998.

Formação sócio-espacial e questão ambiental no Brasil. In: BECKER, Berta K. et al. (orgs.). Geografia e meio ambiente no Brasil. São Paulo: Hucitec, 1995. 
HEGEL, G. W. F. A Verdade da Certeza de Si Mesmo. In: Fenomenologia do Espírito. Petrópolis: Vozes, 2002.

HISSA, Carlos E. Viana. A mobilidade da fronteira: inserções do conhecimento sócioespacial na crise da modernidade. 1998, v.1. Tese (Doutorado em Geografia) - Instituto de Geociências e Ciências Exatas da Universidade Estadual Paulista, Rio Claro.

KOSSOY, Boris. Realidades e ficções na trama fotográfica. São Paulo: Ateliê Editorial, 2000.

LEITE, José F. A Ocupação do Pontal do Paranapanema. São Paulo: Ed. Hucitec, Fundação UNESP, 1998.

MACHADO, Lia O. Limites, fronteiras, redes. In: Tania Marques Strohaecker, Anelisa Damiani (orgs.). Fronteiras e espaço global. Porto Alegre: AGB, 1998.

MAMIGONIAN, Armen. A escola francesa de Geografia e o papel de A. Cholley. In: Cadernos Geográficos. Publicação do Departamento de Geociências - CFH / UFSC, n6, maio de 2003.

MATURANA, Humberto. O que se observa depende do observador. In: GAIA: Uma Teoria do Conhecimento. São Paulo: Gaia, 2001.

MENDONÇA, Francisco. Geografia Socioambiental. In: Elementos de Epistemologia da Geografia Contemporânea. MENDONÇA, Francisco. KOZEL, Salete (orgs.). Curitiba: Ed. da UFPR, 2002.

MOREIRA, Ruy. O círculo e a espiral : a crise paradigmática do mundo moderno. Rio de Janeiro : Coautor, 1993.

NUNES, João Osvaldo Rodrigues et al. Variações texturais dos latossolos vermelhos do assentamento rural Antônio Conselheiro - Mirante do Paranapanema/SP. In: Geografia em Atos, n.6, Volume 1, Presidente Prudente, 2006.

OLIVEIRA, Antonio Manoel dos Santos et al. Tecnógeno: registros da ação geológica do homem. In: SOUZA, Célia Regina de Gouveia et al. (orgs.). Quaternário do Brasil. Ed. Holos, 2005. 
PASSOS, M. Modesto dos. Biogeografia e Paisagem. Programa de Mestrado-Doutorado em Geografia FCT-UNESP/ Campus de Presidente Prudente - SP. Programa de Mestrado em Geografia UEM - Maringá - PR, 1988.

2006.

A Raia Divisória: geossistema, paisagem e eco-história. Maringá: Eduem,

A Raia Divisória: eco-história da Raia Divisória. Maringá: Eduem, 2007.

A Raia Divisória: geo-foto-grafia da Raia Divisória. Maringá: Eduem, 2008.

A Conceituação da Paisagem. In: Formação, Presidente Prudente, n7, 2000. pp. 131-141.

O Pontal do Paranapanema: um estudo de geografia física global. 1988. Tese (Doutorado em Geografia) - Faculdade de Filosofia, Ciências e Letras, Universidade de São Paulo. São Paulo.

Dinâmicas socioambientais, desenvolvimento local e sustentabilidade na Raia Divisória São Paulo-Paraná-Mato Grosso do Sul. Projeto Temático (processo FAPESP: 2005/55505-3), 2005.

PETERS, Edson Luiz. Meio ambiente e propriedade rural. Curitiba: Juruá, 2009.

PINTO, L. GASPAR, J. Planeamento e gestão participada da paisagem. Disponível em: < http://www.esac.pt/cernas/T2-45.pdf>. Acesso em: abril, 2009.

Projec - Engenharia Ambiental. Relatório de impacto ambiental - RIMA: ampliação da Usina Conquista do Pontal, 2009.

RAFFESTIN, Claude. O que é o Território? In: Por uma Geografia do Poder. São Paulo: Ática, 1993. pp.144-220.

RAMALHO. Cristiane B. Impactos Socioterritoriais dos Assentamentos Rurais no Município de Mirante do Paranapanema - Região do Pontal do Paranapanema - SP. Presidente Prudente: UNESP/FCT, 2002. Dissertação (Mestrado) - Faculdade de Ciências e Tecnologia da Universidade Estadual Paulista, 2002. 
RENÓ, Fernanda A. Pinto. Le Sertão Mineiro: Un territoire à la recherche de ses paysages et de ses identités. These. Doctorat de l'Université de Toulouse. Delivré par l'Université de Toulouse II. Géographie de l'Aménagement - Environnement et Paysage. 2009.

RIBEIRO, Rafael W. Paisagem cultural e patrimônio. Rio de Janeiro: IPHAN/COPEDOC, 2007.

RISSO, Luciene C. Paisagens e cultura: uma reflexão teórica a partir do estudo de uma comunidade indígena amazônica. In: Espaço e Cultura. Rio de Janeiro: UERJ, janeiro/junho de 2008.

RODRIGUES, Cleide. A teoria geossistêmica e sua contribuição aos estudos geográficos e ambientais. In: Revista do Departamento de Geografia, 14. São Paulo: USP, 2001.

ROSS, Jurandyr L. Sanches (org.). Geografia do Brasil. São Paulo: EDUSP, 2001.

SÃO PAULO (Estado) Secretaria de Economia e Planejamento. Coordenadoria de Ação Regional. Programa para o desenvolvimento do Pontal do Paranapanema. São Paulo, 1978. 156p.

SACHS, Ignacy et al. (orgs.). Brasil: um século de transformações. São Paulo: Companhia das Letras, 2001.

SANTOS, Milton. A Natureza do Espaço: Técnica e Tempo; Razão e Emoção. $3^{\text {a }}$ ed. São Paulo: Hucitec, 1999.

.Técnica, Espaço, Tempo. São Paulo: Hucitec, 1997.

SAQUET, Marcos A. Abordagens e Concepções de Território. São Paulo: Expressão Popular, 2007. pp.71-85.

Proposições para Estudos Territoriais. In: GEOgrafia, ano VIII, n.15, 2006.

SERPA. Angelo. Parâmetros para a Construção de uma Crítica DialéticoFenomenológica da Paisagem Contemporânea. In: Revista Formação, no 14, v.2 Presidente Prudente: UNESP, 2007. 
SILVEIRA, Flávio L. Abreu da. As complexidades da noção de fronteira, algumas reflexões. In: Caderno Pós Ciências Sociais. São Luís, v.2, n.3, 2005.

SCHIER, R. A. Trajetórias do Conceito de Paisagem na Geografia. In: Revista RA'EGA, Curitiba, n.7, p. 79-85, 2003. Editora UFPR.

SILVA, Lenyra R. A Natureza Contraditória do Espaço Geográfico. São Paulo: Contexto, 1991.

SUERTEGARAY, Dirce Maria Antunes. Espaço geográfico uno e múltiplo. In: Scripta Nova. Universidad de Barcelona, n.93, 2001.

Geografia Física (?) Geografia Ambiental (?) Ou Geografia e Meio Ambiente (?). In: Elementos de Epistemologia da Geografia Contemporânea. MENDONÇA, Francisco. KOZEL, Salete (orgs.). Curitiba: Ed. da UFPR, 2002.

TAVOLARO, Sergio B. de Faria. Movimento ambientalista e modernidade: sociabilidade, risco e moral. São Paulo: Annablume/Fapesp, 2001.

TORRES, Eloiza C. As transformações históricas e a dinâmica atual da paisagem nas microbacias dos ribeirões: Santo Antônio-SP, São Francisco-PR e Três Barras-MS. Tese (doutorado). Universidade Estadual Paulista, Faculdade de Ciências e Tecnologia. Presidente Prudente, 2003.

UNIVERSIDADE DA BEIRA INTERIOR NORTE. Departamento de Gestão e Economia. Estudo prospectivo para o território de fronteira da Beira Interior Norte-Salamanca. Portugal: maio de 2005.2 Disponível em: <www.amdourosuperior.pt/documentos/jmaliste.pdf>. Acesso: março, 2009. 